
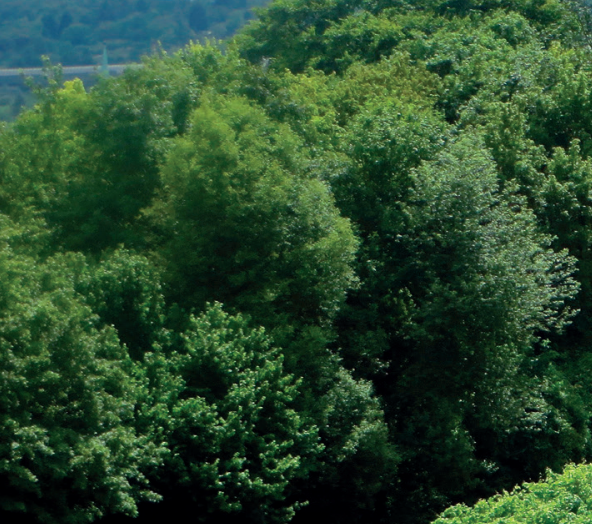

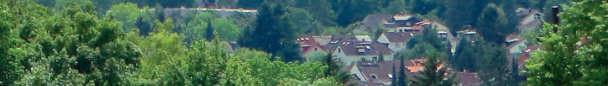
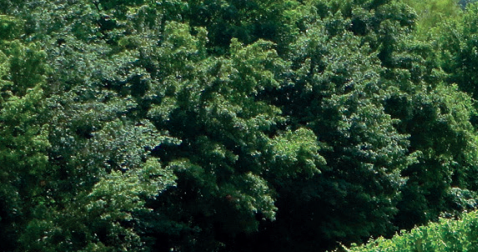

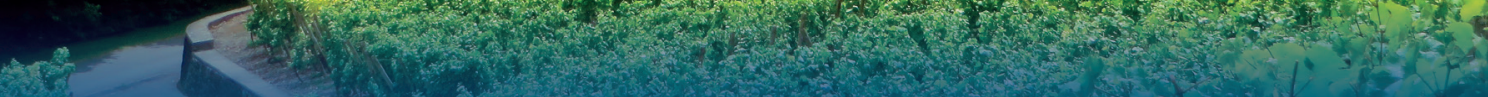

Governing Greenbelts in Southern Ontario and the

Frankfurt Rhine-Main Region: an Institutional Perspective

Sara Macdonald 



\section{GOVERNING GREENBELTS IN SOUTHERN ONTARIO AND THE FRANKFURT RHINE-MAIN REGION: \\ AN INSTITUTIONAL PERSPECTIVE}

Sara Macdonald 
This dissertation was funded by Utrecht University, the Social Sciences and Humanities Research Council of Canada (Grant no. 410-2010-1003), and the German Academic Exchange Service (Project No. 57156825).

\section{Assessment Committee:}

1. Prof. dr. Jörg Dettmar

2. Prof. dr. Douglas Young

3. Prof. dr. Pieter Hooimeijer

4. Prof. dr. Maria Kaika

5. Prof. dr. Edwin Buitelaar
Technische Universität Darmstadt

York University

Utrecht University

University of Amsterdam

Utrecht University
Cover design:

Cover images:

Cartography and Graphic Design:

Printing and Thesis Lay-out:

ISBN:

DOI:
Margot Stoete, Utrecht University

Sara Macdonald and Roza Tchoukaleyska

Ton Markus, Utrecht University

Gildeprint, Enschede

9789464190656

https://doi.org/10.33540/126

(C) 2020 Sara Macdonald. All rights reserved. No part of this publication may be reproduced, stored in a retrieval system, or transmitted, in any form, or by any means, electronic, mechanical, photocopying, recording, or otherwise, without the prior permission in writing for the proprietor 


\title{
GOVERNING GREENBELTS IN SOUTHERN ONTARIO AND THE FRANKFURT RHINE-MAIN REGION: AN INSTITUTIONAL PERSPECTIVE
}

\author{
EEN INSTITUTIONEEL PERSPECTIEF OP HET BESTUUR EN BEHEER VAN \\ GREENBELTS IN ZUID ONTARIO EN FRANKFURT RIJN-MAIN REGIO \\ (MET EEN SAMENVATTING IN HET NEDERLANDS)
}

\section{Proefschrift}

ter verkrijging van de graad van doctor aan de

Universiteit Utrecht

op gezag van de

rector magnificus, prof.dr. H.R.B.M. Kummeling, ingevolge het besluit van het college voor promoties

in het openbaar te verdedigen op

maandag 23 november 2020 des middags te 4.15 uur

door

Sara Macdonald

geboren op 9 juni 1981

te Toronto, Canada 


\section{Promotoren:}

Prof. dr. J. Monstadt

Prof. dr. R. Keil

\section{Copromotor:}

Dr. A.R. Friendly

Dit proefschrift werd (mede) mogelijk gemaakt met financiële steun van Universiteit Utrecht, Social Sciences and Humanities Research Council of Canada (nr. 410-2010-1003) en de Duitse Academic Exchange Service (Project nr. 57156825). 


\section{TABLE OF CONTENTS}

List of Figures IX IX

List of Tables IX

Acknowledgements $\quad$ XI

Preface XIV

$\begin{array}{lll}\text { Chapter } 1 & \text { Introduction } & 17\end{array}$

$1.1 \quad$ The evolution of greenbelts 21

$1.2 \quad$ Theoretical perspectives to explore the governance of greenbelts 23

1.2.1 Urban political ecology 24

1.2.2 Regional governance 26

1.2.3 Institutional perspectives on regional governance 29

$1.3 \quad$ Conceptual framework 32

$1.4 \quad$ Research questions 36

$1.5 \quad$ Research design 38

1.5.1 Data collection and methods 39

1.5.2 Research timeframes 41

1.5.3 Case study selection 42

$1.6 \quad$ Structure of the dissertation 48

$1.7 \quad$ References 49

Chapter 2 Rethinking urban political ecology from the outside in: 57

$2.1 \quad$ Introduction 59

$2.2 \quad$ UPE revisited 60

$2.3 \quad$ The UPE of greenbelts 62

$2.4 \quad$ Thinking about post-suburbanisation 65

2.5 The $\mathrm{GGH}$ region 67

$2.6 \quad$ The GGH greenbelt 69

$2.7 \quad$ "Places to grow: Brighter choices, brighter future" 72

2.8 The greenbelt is not separate from the city 74

$2.9 \quad$ The changing relationship between greenbelts and cities 76

2.10 Conclusion: The GGH greenbelt as boundary in the unbounded 77 region

$2.11 \quad$ References 80 
Chapter 3 The Ontario greenbelt: Shifting the scales of the sustainability fix?

3.2 Placing the greenbelt theoretically: Rescaling, new regionalism and the "sustainability fix"

3.4 The Greater Golden Horseshoe region and the impact of

"business as usual" development

Chapter 4 From the Frankfurt Greenbelt to the Regionalpark RheinMain:

\section{An institutional perspective on regional greenbelt governance}

4.1 Introduction

4.4 The governance of the Frankfurt greenbelt and the Regionalpark RheinMain

4.5 From the Frankfurt greenbelt to the Regionalpark RheinMain Main region

4.6.1 Horizontal coordination: How interdependencies between policy

4.6.2 Vertical coordination: Collaboration challenges between policy levels results in localized greenbelt initiatives

4.6.3 Territorial coordination: Coordination problems across jurisdictions results in the downscaling of activities to the local level

\section{7}

Conclusion 
Chapter 5 Towards smart regional growth: Institutional complexities and the regional governance of Southern Ontario's greenbelt

5.1 Introduction 149

5.2 The governance of regional greenbelts: An institutional 150 perspective

5.3 Key policies of the Liberals' regional planning framework for the 154 GGH region

5.4 The institutional challenges and territorial politics involved in implementing the Greenbelt Plan

5.4.1 Vertical coordination: Greenbelt development as an articulation 158 of provincial-municipal relations

5.4.2 Horizontal coordination: How politics and stakeholder selfinterests undermine greenbelt implementation

5.4.3 Territorial coordination: How leapfrogging reveals unintended 163 impacts of the Greenbelt Plan

$5.5 \quad$ Conclusion

5.6

References

170

5.7 Appendix: Cited interviews

174

Chapter 6 Re-thinking the governance and planning of a new generation of greenbelts

$\begin{array}{lll}6.1 & 179\end{array}$

6.2 Research methodology 180

6.3 The evolution of greenbelts: From traditional models to a new 181 generation of greenbelts

6.4 The institutional dimensions of the governance of regional 184 greenbelts

6.5 Two different institutional models of regional greenbelt planning 186

6.5.1 The GGH Greenbelt: A top-down approach to greenbelt planning 186

6.5.2 The Regionalpark RheinMain: A decentralized model of greenbelt 189 planning

6.6 Institutional complexities and governance challenges of the new generation of greenbelts

6.6.1 Vertical coordination 193

6.6.2 Horizontal coordination 195

$\begin{array}{ll}\text { 6.6.3 Territorial coordination } & 197\end{array}$

6.7 Conclusion 199

$6.8 \quad$ References 201

6.9 Appendix: Cited interviews 204 
$\begin{array}{lll}\text { Chapter } 7 & \text { Conclusion } & 207\end{array}$

7.1 Introduction 209

$\begin{array}{ll}7.2 & \text { Main research findings } \\ 7.30\end{array}$

$\begin{array}{ll}7.3 & \text { Synthesis of key research findings } 220\end{array}$

7.4 Lessons for the future governance and planning of regional 223

$\begin{array}{lll}7.5 & \text { Insights for academic debates } & 228\end{array}$

7.6 Directions for future research 231

$\begin{array}{lll}7.7 & \text { References } & 234\end{array}$

Appendices Appendix A: List of Interviews for the Ontario Case 241

Appendix B: List of Interviews for the Frankfurt Case 245

$\begin{array}{ll}\text { Summary } & 249\end{array}$

Samenvatting 255

$\begin{array}{ll}\text { Curriculum Vitae } & 261\end{array}$ 


\section{LIST OF FIGURES}

Figure 1.1: Conceptual Framework 33

Figure 1.2: Farm within the GGH Greenbelt in Lincoln, Ontario (2014) 45

Figure 1.3: Lake within the Frankfurt Greenbelt (2015) 47

Figure 2.1: The Greater Golden Horseshoe Region 68

Figure 2.2: The Greater Golden Horseshoe Greenbelt 70

Figure 3.1: The Greater Golden Horseshoe Greenbelt 90

Figure 3.2: The Greater Golden Horseshoe Region 97

Figure 3.3: Urban Growth Centres in the Greater Golden Horseshoe Region 101

Figure 3.4: Agriculture in the Greenbelt (2009) 104

Figure 3.5: New Residential Development in the Greenbelt (2009) 106

Figure 4.1: Frankfurt Rhine-Main Metropolitan Region and the Greater 127 Frankfurt Region

Figure 4.2: $\quad$ The Fragmented Regional Governance Landscape in Frankfurt 136 Rhine-Main

Figure 5.1: The Greater Golden Horseshoe Region 155

Figure 5.2: Ontario's Land-Use Planning System 157

Figure 6.1: The Greater Golden Horseshoe Region 187

Figure 6.2: The Frankfurt Rhine-Main Metropolitan Region and the Greater 190 Frankfurt Region

\section{LIST OF TABLES}

Table 6.1: Typology of Greenbelts 183

Table 6.2: Ontario's Land-Use Planning System 189

Table 6.3: The Spatial Planning System in the Frankfurt Rhine-Main Region 191 


\section{ACKNOWLEDGEMENTS}

Writing a dissertation often feels like a long journey. This process has allowed me incredible opportunities to meet wonderful people, be exposed to fascinating ideas and travel to new places. My interest in researching cities and urban planning began during my undergraduate studies at York University. I could never have anticipated at that time where those research interests would lead me over the coming years. As I am finishing my dissertation, I would like to take this opportunity to express my sincere gratitude to all the people who inspired, supported, and encouraged me throughout my PhD journey.

First and foremost, I would like to express my deepest gratitude to my supervisors, Professor Jochen Monstadt, Professor Roger Keil and Dr. Abigail Friendly. Professor Jochen Monstadt provided me the opportunity to come to Utrecht University and without this support, this dissertation would not have been possible. I sincerely appreciate that Jochen shared his academic insights and knowledge about the Frankfurt Rhine-Main region to support my research. His feedback and critical reflections have assisted me with becoming a better researcher and writer, which are invaluable skills that I will continue to use throughout my professional career. In addition, I worked with Professor Roger Keil at York University and through my positions with the City Institute and Global Suburbanisms project, he provided me with significant academic opportunities. Those experiences allowed me to travel to many suburban locations around the world and forever changed the way I think about suburbanisation and suburbanisms. I am thankful to Roger for his sharing his valuable insights and knowledge for my research and for being an excellent mentor. I am also grateful to Dr. Abigail Friendly for her encouragement, feedback, and advice throughout this PhD process. I am thankful that she always made time to meet with me and answer my questions, no matter how minor. Finally, I would also like to thank the committee members for reviewing and evaluating my dissertation including Professor Edwin Buitelaar, Professor Jörg Dettmar, Professor Pieter Hooimeijer, Professor Maria Kaika and Professor Douglas Young.

Second, I would like to thank the many former and current PhD students and other SPGL colleagues who have made these past three and a half years at Utrecht University memorable: Nynke Burgers, Zheyan Chen, Hongbo Chai, Delphine, Ivonne Elsner, Jie Gao, Prince Guma, Paulien Hagedoorn, Yang Hu, Huaxiong Jiang, Mathias Koepke, Valentin Meilinger, Emilinah Namaganda, Burcu Özgün, Hannah Roberts, Rong Yang, Karin Snell, Karlijn Sporrel, Xing Su (Summer), Gül Tuçaltan, Min Yang, Haoran Yang and Marielle Zill. I have enjoyed the many lunch hours, coffee breaks, long chats and get togethers we have shared during my time here. In particular, I would like to thank the following people. Valentin Meilinger and Mathias Koepke, I am grateful that both of you are the paranymphs for my defense. Valentin, we got to know one another when you were a visiting scholar at 
the City Institute several years ago. It has been wonderful to work together as PhD students and I appreciate all your support with my research on the Frankfurt case. Mathias, I always enjoy our conversations and sincerely appreciated your encouragement and support during difficult times throughout the PhD. Xing Su (Summer), I appreciated our discussions and walks in Bunnik, particularly during the intense phase of finalizing my dissertation. Jie Go, I have fond memories of our day trips throughout the Netherlands and was honoured to be a paranymph at your defense. I am also grateful for the administrative support provided by the SPGL secretaries' and faculty administrators who assisted with solving practical problems. I want to thank Ton Markus for preparing many of the maps for my publications, and Margot Stoete for doing this book's cover design. Many thanks go to Gustavo Vieira for his great editing work on several chapters of this dissertation. Finally, I would like to thank Utrecht University, the Social Sciences and Humanities Research Council of Canada and the German Academic Exchange Service for their financial support for this research.

Third, over the past decade, I have developed a strong network of colleagues and friends in the Frankfurt Rhine-Main region, which supported my research on that case study. I am grateful for the support provided by colleagues in the URBANGrad program at Technische Universität Darmstadt including Markus Kip, Derya Pullham, Pinar Bilgic and Anshika Suri. I also would like to thank several faculty members and students from the Human Geography department at the Goethe-Universität Frankfurt am Main including Susanne Heeg, Bernd Belina, Tino Petzold and Sebastian Schipper. Finally, I would like to thank Chris Siegl from the Open Urban Institute in Frankfurt. These colleagues supported my research on the Frankfurt case by introducing me to possible interview participants, explaining the region's governance, political and spatial planning systems and taking me on tours of regional greenspaces. In particular, I would like to thank the following people. Linlin Wei, I have fond memories of our many walks in the Frankfurt greenbelt and was inspired by our conversations about this greenspace. Maximilian Hellriegel, thank you for your research assistance with translating policy documents and attending selected interviews. Finally, Lothar Augustin and Julia Ricarda Reusing, I appreciated your generous hospitality during my visits to Frankfurt and thank you for sharing your insights about the city.

Fourth, I would also like to thank several colleagues and friends for their support throughout the research process. Michael Collens and Sean Hertel, I appreciated all your professional expertise in clarifying land-use planning matters in the Greater Golden Horseshoe region, which greatly enriched the empirical material presented in the Ontario case. Rebeca Dios, it was wonderful to find another researcher studying greenbelts as well and our academic discussions were inspiring and provided new ideas for my work. Lucy Lynch, I am grateful that we continued our working relationship that began on the Global Suburbanisms project, and always enjoyed our conversations about the GGH greenbelt. Laura Waddell 
and Ellen Meadd, I appreciated all your wonderful support, encouragement and cheerleading, particularly during the difficult times throughout the PhD process.

Finally, I want to thank my family for their love and ongoing support through my PhD process, particularly my parents: Lynn and John Macdonald. I know my being away from Toronto over the past few years has not been easy. My father unfortunately died shortly before my arrival in the Netherlands in 2017. In one of the last conversations I had with him, he encouraged me to pursue my dream of moving to Europe to obtain a doctoral degree. While I am deeply sorry that he is not here to see me receive my doctorate, I take comfort in knowing he supported my decision.

Thank you again to everyone to who supported me throughout my PhD process, and I look forward starting on the next chapter.

Sara Macdonald

Utrecht, September 2020 


\section{PREFACE}

This dissertation represents the results of more than 15 years of research on greenbelts, governance and suburbanisation in North America and Europe. Throughout my academic and professional career, I have explored greenbelt development from several perspectives such as regional governance, urban political ecology, green infrastructure, and institutions. For this reason, the progression of articles in this dissertation reflects the evolution of my thinking about these topics, which was shaped and inspired by diverse academic debates and the collaboration with numerous faculty members and graduate students.

My interest in greenbelts and regional planning began in the early 2000s, which was the beginning of a significant period of reform in Ontario's governance and land-use planning landscape. A recently elected Liberal provincial government (2003-2018) introduced ambitious changes to the planning system that included establishing a regional greenbelt and developing a growth plan for the Greater Golden Horseshoe region. This planning legislation was being introduced because the region was expected to grow from 7.7 million people in 2001 to 11.5 million people in 2031, and as urban-sprawl related problems such as poor urban air quality, traffic congestion and the loss of agricultural land continued to worsen. As a result, I became interested and began doing research to examine how this explosive demographic growth was supposed to be accommodated within the region in a more sustainable manner, in a way that was not expected to continue reproducing the traditional low-density development practices commonly associated with North American urban regions.

I became the Coordinator of the City Institute at York University (CITY) from 2006 to 2017, which is a university-based research centre that facilitates critical urban research. For seven of those years, I was also the Project Coordinator of a large academic research project entitled "Global Suburbanisms: Governance, Land and Infrastructure in the $21^{\text {st }}$ century" (2010-2019), which analysed established and emerging forms of suburbanisation around the world. In addition to my administrative roles, I actively contributed to the Global Suburbanisms project as a researcher. Through a sub-project that explored how suburbanisation redefines urban boundaries both conceptually and physically, I continued my research on greenbelts and presented the results at academic conferences and in peer reviewed journals.

During this time, I expanded the scope of my research on greenbelts to an international context. In 2008, I was a visiting scholar at Aberystwyth University in Wales working with Professor Mark Whitehead doing research about the West Midlands greenbelt in England. Then starting in 2011, I made frequent trips to Frankfurt, Germany, where academic 
colleagues took me on tours of that city's greenbelt and introduced me to stakeholders involved in its management. Through these visits, I became interested in learning more about the Frankfurt greenbelt, the Regionalpark RheinMain and comparing those greenspaces to the Ontario case. Thus, doing a PhD builds upon my previous experiences outlined above and expands my research into a trans-Atlantic comparative project focusing on the governance of regional greenbelts from an institutional perspective.

We are now in a quite different position than when my research began in the early 2000 s. My research started before the 2008 financial crisis and the governance and development of land in the Greater Golden Horseshoe and Frankfurt RhineMain regions has changed significantly since that time. In these global city-regions, institutions, organizations, and urban and suburban communities exist that did not five or ten years ago. In the past 15 years, there has also been a shift in academic and policy debates towards more sustainable development and increased attention to the impact of climate change, which influences the governance and planning of urban regions. In North America over the past 10 years, the local food movement has grown considerably, and farmers markets have become increasingly popular. Therefore, food grown close to cities is more easily accessible to urban residents. I have had the opportunity to witness the above changes in various capacities over the past 15 years, explore these ideas through my research and writing, and thus this dissertation is reflective of that journey. 


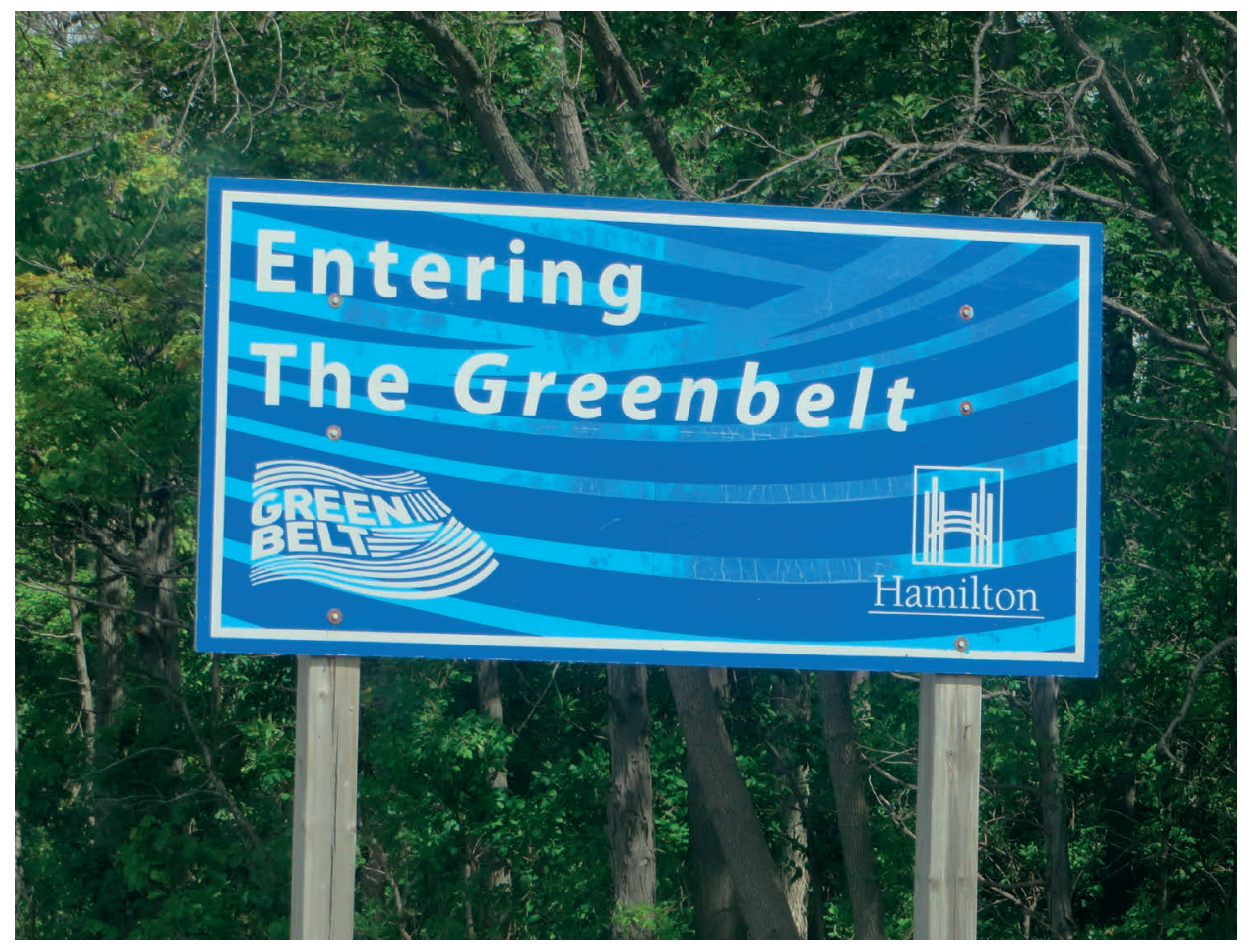

Sign for the GGH greenbelt.

Source: author 
Introduction 

Urban regions are experiencing a dramatic shift in urbanisation processes and urban forms that are transforming the modern metropolis (Soja, 2015). For the past one hundred years at least, the main form of urbanisation has been concentric, with suburbs surrounding a central city (Schmid, 2014). However, in recent decades, urban growth patterns have changed, regions have become more polycentric, and the traditional boundaries between the city and the countryside have blurred. Urban regions have become increasingly complex, heterogeneous, and spatially fragmented landscapes that include a wide variety of densities and land-uses, reflecting what Sieverts (2003) terms 'in-between cities'.

As post-World War II suburbs in North America and Europe have matured, patterns of peripheral development no longer conform to a traditional model of growth centred around core cities (Jonas, 2011). As urban forms evolve, not all suburban development is low density; thus, for example, peripheral growth may now include high-rise tower neighbourhoods (Guney et al., 2019). Rapid suburban growth often results in the destruction of farmland and natural areas for development purposes, highlighting the need for effective growth management strategies to protect these open spaces. In addition, suburban development has, at least in part, co-evolved with the regionalisation of infrastructure services, such as transportation, water, and waste networks, to link cities to the surrounding region. Recent trends to delegate the provision of such public services to the private sector and special purpose bodies result, however, in highly fragmented regional institutional arrangements (Stoker, 1998). In addition, the increasing regionalisation of economic processes shapes new relationships between cities and urban regions, through a regional division of labour, the growing importance of suburban employment nodes, and regional mobility patterns. However, the regionalisation of settlement patterns, economic networks and commuter flows must also be seen within the context of broader processes, such as globalisation and neoliberalisation, as factors such as foreign real estate investment and territorial competition, for example, can significantly impact the development of urban regions (Belina and Lehrer, 2017; Heeg, 2017). Therefore, the complexity of this 'in-between' landscape creates considerable challenges for policymakers in relation to the effective planning and governance of urban regions.

As a result of these shifting conditions, some long-standing planning concepts are being re-thought within academic and policy discourses. Originating in late $19^{\text {th }}$ and early $20^{\text {th }}$ century British planning, greenbelts are designed to act as urban growth boundaries, protect agricultural land and natural areas, and provide recreational spaces for residents (Amati, 2008). While the London greenbelt is the most famous example, greenbelts can be found around many cities, including Copenhagen, Melbourne, Toronto, and Frankfurt. The purposes of these greenbelts and the institutional arrangements shaping their governance have evolved over the past century. Greenbelts 
are viewed as highly valuable greenspaces, which are increasingly important because of the environmental, social, and economic benefits they provide, particularly given the changing global conditions outlined above (Carter-Whitney, 2010).

With the rising popularity of smart growth planning principles over the past two decades (Filion and McSpurren, 2007; Grant, 2009), greenbelts are key strategies to achieving compact urban forms, because they create an urban growth boundary directing development towards cities. Greenbelts also provide significant ecosystem services that build resilience against global environmental change. These greenspaces play an important role in climate adaptation and mitigation by storing greenhouse gases, as well as in protecting local food supplies, and in decreasing biodiversity loss through protecting natural habitats (Natural England and the Campaign to Protect Rural England, 2010; Tomalty, 2012). Greenbelts also provide valuable recreational amenities, such as hiking trails that give residents the opportunity to access natural areas, underlining the growing recognition of the positive physical and mental health benefits associated with spending time in nature (Carrus et al., 2015). Finally, greenbelts make significant economic contributions to a region's economy, as production activities associated with the agricultural and tourism sectors help keep rural economies sustainable (Econometric Research Limited, 2012).

Greenbelt governance is now situated within complex multi-layered institutional arrangements that involve the competing demands of diverse stakeholders, including governments at national, provincial, or state, regional, and municipal levels, as well as groups of developers, farmers, and civil society. The changing institutional designs of greenbelt planning and the growing role special purpose bodies and civil society groups have been taking on in greenbelt management, have further increased greenbelt governance complexity. Yet, questions remain whether greenbelts can effectively stem the tide of suburbanisation in the context of intense development pressures to meet the growing housing and infrastructure needs in many cities and regions. Indeed, urban and suburban development is the largest threat to greenbelts in most jurisdictions (CarterWhitney, 2010), as local growth coalitions often seek to alter a greenbelt's boundaries to release land for building purposes. While suburban infrastructure is necessary for the functioning of a region, allowing the construction and expansion of roadways and other infrastructure within greenbelts can also create negative impacts, which can undermine the environmental protection these greenspaces provide (Filion and Pulver, 2019; Tomalty, 2012). This scenario raises questions for policymakers about governance models for these greenspaces under these changing conditions. Given these complexities, in this dissertation, I aim to explore how institutional arrangements influence the governance of regional greenbelts, and to examine how these greenspaces might be managed more effectively. 
The introduction is organised as follows. First, I outline how greenbelt planning has evolved since its origins more than one hundred years ago in Britain and Europe. Next, I provide an overview of the literature on greenbelts, urban political ecology, regional governance, institutional perspectives on regional governance, and introduce the conceptual framework applied to this research. Following that, I elaborate on my research questions, leading to a discussion of the research design that includes the methodology and research methods I use in this dissertation. Then, I provide the rationale for the case study selection along with an introduction to the two cases examined in this research: The Greater Golden Horseshoe (GGH) greenbelt in Southern Ontario, Canada, and the Regionalpark RheinMain in the Frankfurt Rhine-Main region, Germany. Finally, I provide an outline of the structure of the dissertation.

\subsection{THE EVOLUTION OF GREENBELTS}

As an internationally recognised approach in planning urban regions, greenbelts have been part of planning discourse for more than a century. Greenbelts are natural areas that surround cities, containing a mixture of public and private lands on which development restrictions are placed (Erikson, 2004). The main goals of greenbelt policies include urban growth containment, farmland protection and nature conservation (L. Taylor, 2019). The greenbelt concept has its roots in late $19^{\text {th }}$ and early $20^{\text {th }}$ century efforts to preserve natural areas around European cities, such as Berlin and Paris, and other greenspace projects, such as parkways (Freestone, 2002; Konijnendijk, 2010). However, greenbelts are most strongly connected to British town planning and specifically, to Ebenezer Howard's Garden City concept (Amati, 2008; Sturzaker and Mell, 2017).

Developed in response to rapid urbanisation, industrialisation and the resulting unhealthy urban conditions of that time, greenbelt policies were designed to provide open spaces for urban residents, separate cities from rural areas, confine urban growth, and preserve farmland (ibid.). Under the influence of civil society groups that sought to preserve the countryside, and of planners, including Patrick Abercrombie and Raymond Unwin, greenbelts became a key component of UK planning policy, leading to the 1938 establishment of the London greenbelt (Sturzaker and Mell, 2017).

Greenbelts reached their highest popularity in the early post-World War II years until the 1970s. The greenbelt concept thus spread internationally to cities such as Melbourne, Copenhagen, and Seoul (Amati, 2008), reflecting a transnational flow of planning ideas (cf. Healey, 2013). Greenbelt initiatives in those cities were influenced by the UK planning model, and it was assumed that the greenbelt concept could be universally applied to any 
context and achieve similarly effective results to the London case (Amati, 2008). However, when the greenbelt concept was transplanted to those cities, policies were modified to each city's specific needs, resulting in a wide variation in policy objectives and diverse spatial forms, such as green wedges (ibid.).

The greenbelt polices that developed several decades ago - particularly those in the UK are increasingly seen as anachronistic and needing reform to address the current challenges facing suburban areas (Mace, 2018; Sturzaker and Mell, 2017). Thus, since the 1990s, a new generation of greenbelts has developed, and the concept has been reconsidered and reformed to reflect changing societal views on the environment. In addition, as a result of the evolution of urban regions in recent years (Galland and Harrison, 2020), greenbelts are now situated within highly suburbanised regions, influencing the planning of these greenspaces. Building upon past policy goals, including urban growth control and farmland preservation, these recent greenbelts have new objectives, such as climate change mitigation and adaptation, providing ecosystem services, and contributing to economic development strategies and regional identity (Amati and Taylor, 2010; Natural England and Campaign to Protect Rural England, 2010). This multitude and diversity of objectives reflect the recent popularity of multi-functional policies within planning practices (Gallent et al., 2006). However, the multi-functionality of new generational greenbelts increases the number of stakeholders involved in policy implementation at various policy levels, expanding the governance challenges related to their management. These recent greenbelts also have more flexible governance approaches, in which the private sector, public-private partnerships and civil society groups are taking more responsibility for greenbelt management.

Finally, as planning policies designed to contain urban growth, greenbelts have become an essential part of regional growth management strategies, constituting an important element of smart growth and compact city agendas. Smart growth is a planning approach that began in the United States in the late 1990s, emerging in reaction to conventional low-density development practices (Filion and McSpurren, 2007; Grant, 2009). Using approaches that involve stricter land-use planning regulations, smart growth's principles include urban intensification, mixed land-uses and transit-oriented development, which have been increasingly applied by policymakers (ibid.), reflecting broader shifts within planning discourse towards more sustainable development.

Likewise, in Europe, the planning concept of the compact city has been used to reflect policymakers' attempts to contain urban growth, densify neighbourhoods and protect natural areas, reflecting similar aims as those of North American smart growth policies (Westerink et al., 2013). The main difference between these two concepts is that the compact city debate has concentrated more on the intensification of urban areas and 
does not have a regional focus (ibid.). However, it can be challenging to implement these planning principles effectively, because strong political will, developer interests and market influences often impact planning practices broadly (Grant, 2009), and greenbelt planning specifically.

Within greenbelt debates, my research aims to address some existing literature gaps. Greenbelts have been examined as part of new forms of multi-scalar regionalism (Addie and Keil, 2015), as a strategy by which nature is used to justify growth management (Wekerle et al. 2007), as a mechanism to promote environmental governance practices (Kortelainen, 2010), and through the perspective of the civil society groups involved in managing these greenspaces (Burton, 2016). However, aside from these contributions, greenbelt governance is rarely discussed within the literature.

In addition, academic debates have focused on the role that institutional environments play in shaping policy design (Han and Go, 2019; Pond, 2009), and how greenbelt policies can be resistant to reform (Mace, 2018). However, the institutional perspectives in this literature hardly reflect upon the governance of these greenspaces, with some exceptions (Röhring and Gailing, 2005).

Finally, while some literature compares greenbelt planning in different countries (Aguado et al., 2017; Amati, 2008; Carter-Whitney, 2010; Kühn, 2003), this scholarship does not take an institutional perspective on managing these greenspaces, with one exception (Han and Go, 2019). Therefore, my research aims to address these literature gaps using a comparative analysis of the institutional complexities of regional greenbelt governance.

\subsection{THEORETICAL PERSPECTIVES TO EXPLORE THE GOVERNANCE OF GREENBELTS}

This research builds upon three academic debates to explore the governance of greenbelts: urban political ecology, regional governance, and institutional perspectives on regional governance. As the focus of my study is on the management of regional greenbelts, the main theoretical framework used within my research is regional governance. I use two other theoretical approaches in addition, to explore greenbelt planning. First, I use an urban political ecology approach to understand what greenbelts are and how they are produced and reproduced. Second, I apply an institutional approach on the governance of regional greenbelts to examine how institutions shape policy implementation. In the following sections, I review each of these academic debates, before outlining the conceptual framework applied to this research. 


\subsubsection{Urban political ecology}

An urban political ecology (UPE) approach provides a valuable perspective to examine the planning of a new generation of greenbelts. In a UPE perspective, greenbelts can be viewed as hybrid spaces created by ecological, social, economic, and political processes, which are enabled through relationships between society and nature (Swyngedouw, 2004; Zimmer, 2010). Thus, seeing greenbelts as hybrid spaces provides a useful starting point to understanding how their governance is shaped by broader socio-environmental relationships.

In addition, as planning policies intended to contain urban growth, greenbelts are traditionally designed to create a firm division between the urban and the rural. However, societal relationships with nature have evolved over time, with natural environments no longer being seen as separate from the city (Swyngedouw and Kaika, 2014; Wachsmuth, 2012). Therefore, as a UPE approach challenges the binaries between urban and natural environments, this theoretical lens can be used to examine how those traditional divisions associated with early $20^{\text {th }}$ century greenbelts need to be rethought to reflect the current conditions found in today's urban fringe.

Rooted in Marxist concepts of nature and social relations, UPE emerged as an attempt to reconcile divisions between society and nature within political ecology, and to extend that focus to include cities (Angelo and Wachsmuth, 2015; Swyngedouw, 1996). Thus, according to Heynen et al. (2006), urban political ecology provides a theoretical framework to critically examine the interconnected socio-ecological processes happening within cities. This perspective views all environments as socially produced and reproduced, and the transformation of natural and social relations as connected to urbanisation processes (ibid.). Following this approach, nature is not seen as independent of the social (i.e. nature is seen as socio-nature), and all features of urbanisation are therefore considered socio-natural (Swyngedouw, 1996; Wachsmuth, 2012). In addition, this production and reproduction of nature is viewed as embedded within networked scalar configurations that link socio-ecological processes operating from the local to global scales (Heynen et al., 2006; Swyngedouw and Heynen, 2003). Thus, the urbanisation of nature is not only local but often global.

In capitalist societies however, nature becomes incorporated into social relations of control and ownership, with this commodification of nature obscuring the power relations that drive capitalist urban processes (Heynen et al., 2006). Thus, the production and reproduction of nature is seen as embedded within highly uneven power relationships that often benefit privileged actors at the expense of marginalised ones (ibid.; Swyngedouw and Heynen, 2003). UPE critically examines the deeply unjust power relations through which socio-environmental conditions are produced, along with the power struggles over urban environments (ibid.). 
UPE focuses on the production of nature related to urban metabolism. While urban metabolism is often presented in the urban literature as the material flows of water, waste and energy within and out of cities, UPE sees urban metabolisms in an intensely political manner, focusing on the interaction of socio-natures in forming urban spaces (Heynen et al., 2006). Thus, a central contribution of UPE has been to seek a deeper understanding of urban metabolism to show that these metabolic change processes are often dominated by humans, which are themselves governed by specific social rules, regulations and capitalist economies (Heynen, 2014; Zimmer, 2010). In addition, UPE's integrated perspective of socio-nature stands in contrast to historical approaches that viewed nature in opposition to the city (Swyngedouw and Kaika, 2014; Wachsmuth, 2012). UPE aims to challenge such dualist thinking about the city and the countryside, nature, and society, and to complicate these binaries within urban socio-natural processes (Heynen, 2014; Wachsmuth, 2012).

UPE debates have been criticised for their alleged 'methodological cityism', which entails having an exclusive analytical lens on cities with limited focus placed on regional issues and suburbanisation (Angelo and Wachsmuth, 2015). However, Tzaninis et al. (2020) and Connolly (2019) have argued that this is not the case, as UPE debates have always moved beyond the city to include non-urban areas since their origins. Through my research, I add to these discussions by contributing to a better understanding of the UPE of suburbanisation through the lens of greenbelts. An urban political ecology lens has rarely been applied to the study of greenbelts, with the following exceptions (Allen, 2014; Keil, 2018). Furthermore, few contributions within UPE have dealt directly with the types of boundary questions in relation to greenbelts and suburbanisation that are examined within this research.

As UPE examines the underlying power relations involved in producing and reproducing urban environments, scholars have long engaged with issues related to governance. Governance within Marxist-oriented UPE approaches emphasise political-economic processes and macrolevel discourses, seeing power as context-specific and dispersed among a broad array of actors (Cornea et al., 2017). In contrast to earlier UPE literature that focused on the practices of elites, recent UPE scholarship pays more attention to the everyday practices of governance (Tuçaltan, 2019; Zimmer and Sakdapolrak, 2012). Thus, the actions of actors such as municipal councillors, non-governmental organisations or local leaders often play a key role in policy implementation and project development (Cornea et al., 2017) ${ }^{1}$. Despite this actor-oriented focus, the concept of governance could

1 Literature focusing on everyday practices of governance views governance as occurring within and beyond the state with a diversity of actors, and examines the actual practices of how interests are pursued, power institutionalised, and authority challenged (Cornea et al., 2017; Le Meur and Lund, 2001). 
be examined in greater depth and better theorised within UPE debates (Gabriel, 2014). In addition, this focus in UPE research on macrolevel political and economic processes driven by capitalist societies does not often reflect on institutional perspectives on governance, specifically those focusing on the role of formal institutions in producing and reproducing urban environments. Therefore, this research aims to address these gaps in the literature by examining the governance of hybrid greenspaces and their shaping by institutional arrangements.

\subsubsection{Regional governance}

Greenbelt policy implementation has evolved in recent decades to include arrangements with diverse stakeholders at several policy levels and across multiple policy domains, with the management of these greenspaces increasingly involving the private sector, publicprivate partnerships, and non-governmental actors. In addition, regional greenbelts cross multiple municipal and special purpose bodies' territorial jurisdictions. Therefore, I argue that it is necessary to apply a regional governance perspective when analysing new generation greenbelt implementation.

Given the growing need for policymakers to address complex problems related to the impact of climate change, environmental degradation, rapid urban- and suburbanisation, neoliberalisation, and globalisation, urban regions are an important scale for policy interventions in the $21^{\text {st }}$ century (Galland and Harrison, 2020). ${ }^{2}$ In recent decades, regionalisation processes have gained attention within academic and policy discourses, which go beyond state-focused notions of this concept to include a wide range of private and civil society actors (Schulz et al., 2001). However, regionalisation needs to be distinguished from regionalism, as that difference is rarely made clear in the literature. Regionalisation can be defined as the increase of functional relationships at the regional scale that can lead to the formation or shaping of regions, resulting in social and political networks at a regional scale or the emergence of regional organisations (Fawcett, 2004). In contrast, regionalism can be seen as a policy or project in which state and non-state actors coordinate to pursue common goals related to specific issues within a given region (ibid.).

In the past several decades, the traditional relationships between central cities and their peripheries have evolved, as urban regions have become more polycentric and their surrounding areas have been gaining increasingly important roles in social and

2 The concept of the region can be difficult to define as its meaning has been modified and challenged within academic debates over the past century (see Paasi et al., 2018). In the past, regions were viewed as sub-state territories that were important for national state projects. Recently, regions have come to be seen as less of a territorial bounded unit and rather as shaped by an array of networks and flows, stretching far beyond their borders (ibid.). 
economic relations. These functional and socio-economic relationships extend beyond the boundaries of a single territorial jurisdiction, as seen through regionalised patterns of suburban development, commuter flows, divisions of labour and service industries, along with regional flows of water, waste and energy (Balz and Zonneveld, 2020). As these spatial developments and flows are regional or multi-scalar in scope, policy formation at the regional scale is considered more effective (ibid.). Thus, there is an increasing regionalisation of sectoral policies, such as economic development or transportation, which are often used as spatial strategies to enhance territorial competitiveness (Addie, 2017; Gordon, 2007).

However, this regionalisation of policies comes with several challenges for policymakers. First, there is a growing mismatch between spatial development processes that leads to societal problems and the scope of territorial governance, which may create institutional voids (Balz and Zonneveld, 2020; Hajer, 2003). Second, despite spatial developments and flows extending across and often beyond urban regions, public service provision and sectoral planning still operates within bounded territorial units (Addie, 2017). Finally, institutional arrangements often have a traditional focus on the urban core, placing the surrounding areas in a dependent position and reinforcing power asymmetries (Salet et al., 2015). Given this complex regionalisation and the challenges policymakers face in managing them, this raises questions about how to best plan and govern urban regions in light of these conditions.

Governing urban regions has become a complex process involving the coordination of numerous actors within a multi-layered institutional environment to effectively achieve policy outcomes. Regional governance debates are shaped by broader debates on governance, which can be defined as a more networked form of decision-making that goes beyond the state to involve a diversity of non-state actors in policymaking and service delivery processes (Haughton et.al, 2010). Willi et al. (2018) identify three major understandings of regional governance in the literature: First, as a theoretical concept, it analyses the diversity of stakeholders involved in coordinating regional development processes. Secondly, as an empirical description, it reflects the redistribution of state responsibilities, whereby public tasks are delegated to private actors, public-private partnerships, and special purpose agencies leading to a change in the spatial scope of politics beyond administrative jurisdictions. Thirdly, in a normative manner, it can be understood as a tool to strengthen regional performance and foster sustainable development (ibid.). This research uses the above theoretical concept and empirical description of regional governance, following Willi et al. $(2018,12)$ in defining regional governance as the "network-like coordination of regional development processes and comprises vertical and horizontal coordination of state and non-state actors in a functional space." 
A specific form of regional governance discussed within academic debates is metropolitan governance, which can be defined as the regional governance of metropolitan regions. Metropolitan governance and regional governance are frequently used interchangeably within the literature. These variations are often tied to language differences, what term is most commonly used within a specific country or region, and whether there are national and supranational initiatives to define and promote metropolitan regions. Academic debates on metropolitan governance are also strongly based on American and Western European experiences (Heinelt and Kübler, 2005; Matkin and Fredrickson, 2009). However, this research focuses on regional governance because the above understanding of metropolitan governance is only applicable to one of the cases, which I explain later within the introduction.

Regional governance debates have changed considerably in recent years in the literature, with some scholars arguing that there has been a shift from government to one on governance (Peters and Pierre, 2000; Rhodes, 1996). However, other scholars have criticised these claims of a reduction of state involvement as being overstated (Goetz, 2008; Koch, 2013). While an analytical shift from government to governance is evident within political science and urban studies literature, whether that same transition has occurred empirically is questionable.

Within these evolving regional governance arrangements and broader trends such as globalisation and neo-liberalisation, there is a growing pressure on regional policymakers to adjust their practices and institutions to address the challenges and potential outcomes created by these changing conditions. First, in recent years there has been an increasing delegation of government responsibilities for public service delivery to the private sector and voluntary organisations, particularly for services related to transportation, energy, water supplies and waste disposal (Benz, 2001; Stoker, 1998). This outsourcing of services creates considerable challenges, as it leads to the creation of multiple different authorities with overlapping territorialities, which increases regional institutional fragmentation (Storper, 2014). This fragmented institutional environment can create substantial coordination problems for stakeholders, which can ultimately influence effective regional governance. Second, as discussed earlier, urban regions are increasingly functionally interconnected spaces that are linked together by regional divisions of labour and service industries along suburban growth at the regional scale, which transcend municipal boundaries. Regional public policy issues such as housing, nature conservation, transportation, and the provision of other infrastructure services, such as water or waste, often cannot be effectively tackled within municipal boundaries. Therefore, it is beyond the capacity of individual municipalities to solve regional issues themselves, instead requiring authorities to coordinate across territorial boundaries to effectively manage these concerns. 
However, Nelles (2013) finds that coordination amongst stakeholders is shaped by factors such as power asymmetries between municipalities, institutional constraints and the role of leadership, which can influence these stakeholders' governance capacity and thus, their ability to address regional issues. As regional governance arrangements are institutionally fragmented and involve multiple stakeholders with often competing interests, policymakers must now operate within these increasingly complex conditions, creating serious challenges for their capacity to achieve policy goals effectively.

Within regional governance debates, this research aims to address the following literature gaps. The literature highlights several issues strongly, including regional economic growth and development policies (Gordon, 2007), regional innovation (Huggins and Thompson, 2018) and the regionalisation of sectoral policies, such as transportation (Addie, 2017). It also focuses on uneven geographies of urban regions with changing spatial divisions of labour and service industries (Hansen and Winther, 2009). However, these academic debates give less attention to regulating the negative externalities which may be caused by regional growth, such as environmental degradation related to land consumption, traffic congestion and rising pollution levels. In addition, environmental issues are rarely reflected in regional governance debates, with some exceptions (Gibbs and Lintz, 2016; Guay and Hamel, 2015). Thus, this research aims to contribute to addressing these literature gaps by examining the regional governance of greenbelts.

\subsubsection{Institutional perspectives on regional governance}

As greenbelt policies reflect the institutional settings in which they were created (Pond, 2009), I argue that an institutional perspective is insightful to examine regional greenbelt governance. The institutional context of each city or region, especially their land-use planning controls and laws about farmland preservation and nature conservation, shapes greenbelt policy formation, resulting in variation in governance models, policy goals and spatial forms across international greenbelt cases (Han and Go, 2019). Regional greenbelt management thus happens within complex institutional arrangements. Within urban and regional governance debates, institutions are seen as essential for spatial development, as the design of these institutions structures the governance of cities and regions (Z. Taylor, 2019). However, regional policymakers must increasingly operate in conditions that present considerable challenges to governing urban regions effectively. The increasing delegation of a range of public services to special purpose bodies and public-private partnerships, often having overlapping jurisdictions, has resulted in institutionally fragmented urban regions that in many cases create coordination challenges for stakeholders. Recent planning practices reflect the complexity of this institutional landscape, as governments are subject to new policy demands and are 
involved in new institutional reforms (Healey, 2005). Thus, scholars question the capacity of regional organisations to effectively achieve their policy goals given these fragmented institutional environments (Galland and Harrison, 2020).

In this research, I define institutions as "systems of rights, rules, and decision-making procedures, ... [which] give rise to social practices, assign roles to the participants in these practices and govern the occupants of the various roles" (Young et al., 2008, xiii). Thus, institutions create order, enable, and constrain actors, are carriers of identity and distribute power relations (March and Olsen, 2011). Organisations are shaped by institutions, which are "social entities and corporate actors, usually with a formalised membership, staff, a budget and a specific legal status" (Breit and Troja, 2003, 15). Within institutionalism, formal institutions refer to constitutions, laws, and regulations, while informal institutions consist of traditions and cultural values (ibid.). While my research uses the above understanding of institutions, there are other institutional approaches within academic debates: historical institutionalism, rational choice institutionalism and sociological institutionalism. Each of these perspectives explore processes of institutional change and stability (see Peters, 2019; Hall and Taylor, 1996). Institutionalist debates can also highlight a two-way relationship between institutions and society, as both institutions shape actors' practices and actors influence institutions (Scharpf, 1997; Smith, 2005). While institutions enable and constrain the interactions between actors, and shape their outcomes, those actions are not only determined by institutional settings. Instead, actors are seen as having choice regarding their behaviour within these institutional constraints, and in changing institutions as well (Scharpf, 1997). Moreover, institutions provide the "rules of the game" of governance processes, as they shape actors' interactions and decision-making processes, influencing the outcomes resulting from these interactions (Hohn and Neuer, 2006, 294). In relation to greenbelt planning, once policies have been established, actors can anticipate the continuation of these institutions and adjust their behaviours accordingly (Mace, 2018). For example, civil society groups can form to promote these greenspaces, and developers can shift their development practices elsewhere within a region.

Within regional governance debates, several prominent institutional perspectives address questions such as how to best manage regional issues and what are the most effective regional institutional arrangements (Galland and Harrison, 2020). There is ongoing academic debate about what regional institutional form is most appropriate, which includes three different models: the metropolitan reform tradition, the public choice school and new regionalism (see Glass, 2018; Nelles, 2012; Savitch and Vogel, 2000). The metropolitan reform model advocates government consolidation through annexation or amalgamation with proponents contending that overarching regional or metropolitan government bodies are more effective in implementing public policies by overcoming administrative 
fragmentation, avoiding blame shifting between scales, and limiting free rider problems (Nelles, 2012; Savitch and Vogel, 2000). In contrast, scholars of the public choice approach argue that market forces, not governments, should determine regional forms and that institutional fragmentation along with the resulting inter-municipal competition can create a quasi-market situation, and thus more efficient service delivery (Glass, 2018; Nelles, 2012). New regionalism emerged in the 1990 s as a critique of earlier theories. Advocates of this approach noted that effective regional governance does not require institutional consolidation, but that municipal fragmentation and free rider problems can be overcome through collaborative arrangements involving public-private or intermunicipal partnerships and voluntary collaboration within urban regions (ibid.). Overall, the debate regarding these three institutional models raise questions about the capacity of these different approaches to effectively coordinate policymaking across institutionally fragmented policy environments and how different regional institutional forms can address the following three problems.

First, recent academic and policy discourses have shifted from discussing formal hard territories of institutional activity towards soft spaces with more porous borders (Allmendinger et al., 2014; Heley, 2013; Paasi and Zimmerbauer, 2016). Such soft spaces of governance can be defined as "the result of a deliberate, conscious strategy constructed by governing actors (usually public sector led) to represent a geographical area in a particular way that lies outside of the political-administrative boundaries and internal territorial divisions of the nation state" (Walsh et al., 2015, 5). These soft spaces are often accompanied by fuzzy boundaries, which do not conform to political or administrative territorial units (Heley, 2013). Soft spaces of governance are seen as more adaptable to the diverse range of issues and stakeholders involved in land-use planning activities. Yet, these spaces are not often well institutionalised (ibid.). Soft spaces can be seen as part of broader processes produced within multi-level governance arrangements due to regionalisation, which are changing territories, particularly in England and European countries (Caruso et al., 2019; Metzger and Schmitt, 2012). However, this shift in the spatial organisation of land-use planning creates challenges for policymakers, as they still need to work within institutional arrangements based on bounded territorial units in order to effectively govern urban regions (Heley, 2013; Paasi and Zimmerbauer, 2016).

Second, governance now often occurs within multi-level governance arrangements involving stakeholders at several territorial scales (Hooghe and Marks, 2003). Regional greenbelt implementation also works within a multi-layered governance setting, as managing these greenspaces involves stakeholders at several policy levels including the national, provincial, regional, or municipal scales. However, while cities and regions have increasingly complex problems that requires support from several policy levels to 
address them, multi-level governance arrangements also create considerable coordination challenges between the various organisations and stakeholders involved, influencing effective policy implementation (Hooghe and Marks, 2003; Horak, 2012).

Finally, inter-policy coordination, or the coordination of sectoral policies, focuses on managing policy issues extending across multiple policy fields and the jurisdiction of numerous government departments (Stead and Meijers, 2009). With the multifunctionality of greenbelt policies, implementation now involves coordination across diverse policy fields such as housing, nature conservation, agriculture, and recreation. However, effective intersectoral policy coordination is becoming harder to achieve due to increasing regional institutional fragmentation, the diversity of stakeholders involved in policymaking processes, and the growing complexity of public policy issues that governments must address (ibid.).

Within institutional debates, my research addresses the following literature gaps. Scholarship about environmental policies at the international level (Oberthür and Gehring, 2006; Young et al., 2008;) and at the local scale (Falleth and Hovik, 2009; Meyer and Konisky, 2007) is well developed within institutional debates. However, the regional level is not yet well reflected within institutional debates related to environment policy, with some exceptions (Moss, 2004). In addition, existing institutional literature mostly focuses either on the institutional challenges of regional governance in fragmented spaces (Storper, 2014), multi-level governance arrangements (Alcantara et al, 2016; Young and Horak, 2012), or siloed policy domains (Stead and Meijers, 2009). However, the governance complexities resulting from the interaction of horizontal, vertical, and territorial institutional arrangements have hardly been addressed within these debates, with some exceptions (Moss, 2004). Therefore, this research aims to address these literature gaps by analysing the governance of regional greenbelts from an institutional perspective.

\subsection{CONCEPTUAL FRAMEWORK}

Building upon the literature reviews outlined above, this conceptual framework is designed to explain how institutional arrangements shape regional greenbelt governance and how these structures influence effective policy implementation (Figure 1.1). This framework allows for an examination of how institutions shape the coordination of the multiple stakeholders involved in regional greenbelt management and how governance challenges resulting from institutional fragmentation affect policy outcomes. Regional governance provides the overarching theoretical lens for my conceptual framework, as the main focus of my research is on the governance of regional greenbelts. I use two 
additional theoretical approaches within this conceptual framework to understand and examine regional greenbelt planning. To begin with, an urban political ecology lens is applied to my research to understand what greenbelts are and how they are produced and reproduced. Afterwards, an institutional perspective on regional greenbelt governance is used to explain how institutional arrangements influence policy outcomes, specifically through three forms of institutional coordination.

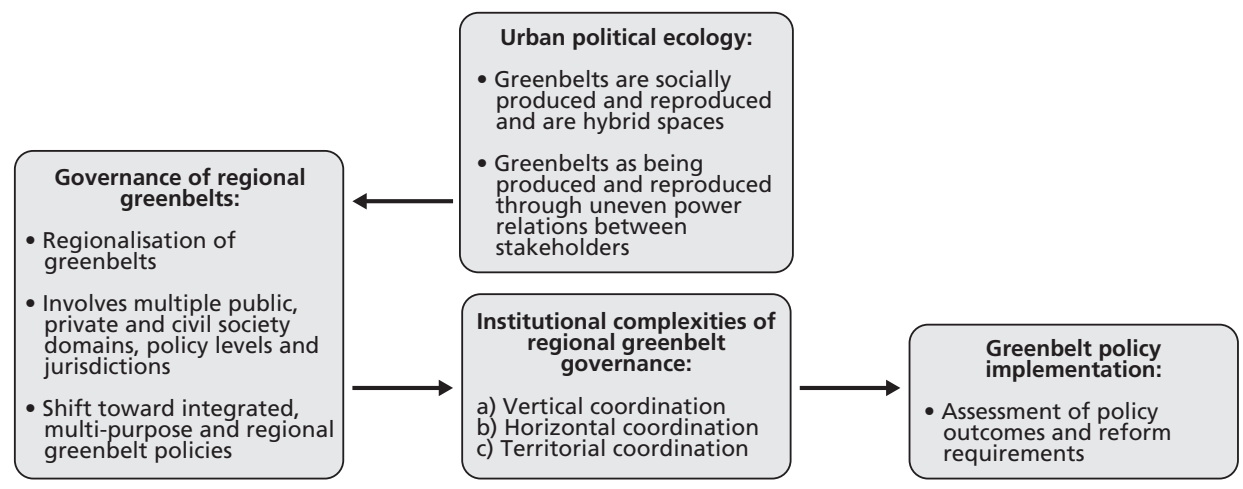

Figure 1.1: Conceptual Framework

Source: author

First, an urban political ecology (UPE) approach provides important insights to understand how greenbelts are constituted and how they are produced and reproduced. As discussed above, within a UPE perspective, greenbelts can be viewed as hybrid spaces that are socially produced and reproduced, as social and environmental processes combine to produce these urban and suburban environments. Thus, viewing greenbelts as hybrid spaces provides valuable insights as the production and reproduction of these natural environments cannot be seen independently from the historical, political, social, and economic conditions that accompany them (Heynen et al., 2006). In addition, within UPE, natural environments are seen as situated within geographical scalar configurations going from local to international levels (Swyngedouw and Heynen, 2003). Thus, greenbelts can be viewed as being embedded within complex territorial scalar arrangements, extending beyond the local or regional scale of these greenspaces. UPE can also be used to examine the underlying political, economic, and social processes involved in producing and reproducing natural environments, which often include uneven power relations between stakeholders (Heynen et al., 2006). Therefore, UPE provides a useful approach to examine which stakeholders gain or lose through greenbelt planning, and to highlight the sometimes-unjust socio-environmental conditions under which these greenspaces are produced and maintained. 
Second, as discussed earlier, regional greenbelts are now situated within complex governance arrangements. Reflecting current trends towards more flexible governance approaches within urban regions (Nelles, 2012; Paasi and Zimmerbauer 2016), the private sector, special purpose bodies and civil society groups often have an increased role in greenbelt implementation. In addition, the multi-functionality of new generation greenbelts requires the involvement of more stakeholders from a broad range of policy domains in greenbelt management. Thus, greenbelt implementation now involves a diversity of stakeholders, such as government officials, developers, farmers, and environmentalists, which often place competing demands on these greenspaces. Finally, as greenspaces have become regionalised, regional greenbelt management involves the coordination of stakeholders across multiple local and special purpose agencies jurisdictions. For these reasons, I argue that it is necessary to apply a regional governance perspective when analysing new generation greenbelt implementation.

Finally, as institutional arrangements strongly influence environmental policy formation and implementation (Briassoulis, 2004), I argue that an institutional perspective is needed to understand regional greenbelt governance. The governance of regional greenbelts occurs within fragmented institutional settings with diverse stakeholder groups. Therefore, this complexity can create challenges at all stages of the policy cycle, including agenda setting, formulation, adoption, implementation, and evaluation. In addition, a specific city or region's land-use planning regime may have various planning regulations to protect greenbelts (L. Taylor, 2019). This variation in greenbelt planning regulations contributes to the multiplicity of policy objectives and spatial forms seen internationally. For this conceptual framework, I have identified three dimensions to examine how institutions shape greenbelt policy implementation in spatially distinct ways: vertical, horizontal, and territorial coordination. Bringing together these three forms of institutional coordination allows for an analysis of the institutional problems involved in regional greenbelt governance, which I explain in more detail below.

A significant issue influencing greenbelt implementation is the vertical coordination of greenbelt policies between stakeholders at numerous policy levels - municipal, regional, provincial, or state ${ }^{3}$. Greenbelt policy implementation is often characterised in the literature as a top-down process whereby a higher-level government sets the policies, which are then implemented by a lower level of authority (Carter-Whitney, 2010). However, vertical coordination is often a more complicated arrangement

3 Federal or national governments are not included in this conceptual framework, as authorities at this policy level either have no role or limited involvement in greenbelt planning in both of my cases. However, that is not true in other international greenbelt examples, such as in England. 
combining both top-down and bottom-up approaches from multiple policy levels. Given this vertical institutional design, how senior levels of government frame greenbelt policies is crucial, because it shapes the responses from municipal stakeholders to these policies (Han and Go, 2019). However, power asymmetries between these different government authorities often result in coordination problems which impact policy outcomes.

Horizontal coordination results from interdependencies between institutions at the same policy level - municipal, regional, provincial, or state. Many policy domains have stakes in greenbelt management, complicating horizontal governance. These include land-use planning, nature conservation, agriculture, transportation, housing, tourism, and their associated stakeholders in the public and private sectors, along with civil society groups. However, this multi-functionality of greenbelt policies creates challenges, as it requires the coordination of multiple government departments for effective implementation to occur. Yet, these departments often operate within siloed policy domains and may not communicate well with one another. As greenbelt management involves multiple overlapping policy areas, inconsistencies in greenbelt policies can influence implementation, such as allowing transportation networks within these greenspaces (Fung and Conway, 2007). Local growth coalitions including developers and real estate investors usually have the financial resources to disproportionately impact land management practices (Hawkins, 2014). Thus, these pro-growth stakeholders often try to influence politicians, resulting in politics and development interests strongly shaping greenbelt policy implementation.

Regional greenbelt policy implementation involves territorial coordination across multiple municipal, regional, and special purpose agencies' jurisdictions. The interaction of stakeholders from several policy fields which often having separate yet overlapping territorial jurisdictions and the fact that these greenspaces are situated within fragmented institutional arrangements also impacts regional greenbelt management. However, these various territorial jurisdictions rarely match greenbelts' spatial boundaries, resulting in possible institutional "misfits," and coordination problems (Young, 2002). Conflicts can also arise along a greenbelt's boundaries, influencing effective policy implementation. For example, developers often pressure governments to alter greenbelt boundaries to release land for residential development, which can cause civil society organisations to protest these proposed policy reforms. In addition, given that municipalities often take wide discretion in applying greenbelt policies, uneven greenbelt implementation across an urban region may result. 
All three of these types of coordination are interrelated. Strong and consistent guidance from higher levels of government is needed about how coordination between these three dimensions should happen, or else greenbelt implementation can be undermined by politics and pro-growth interests. Based on the above literature reviews and this conceptual framework, the next section will outline the research questions framing this research.

\subsection{RESEARCH QUESTIONS}

The overall research objective is to obtain an understanding of how institutions influence the governance of greenbelts by analysing policies in two case study locations: the Greater Golden Horseshoe and the Frankfurt Rhine-Main regions. This information can assist in creating recommendations for how regional greenspaces might be better managed in the future. As the complexity of institutional arrangements and regional governance practices increased in recent decades, this research aims to explore how these changing conditions affect greenbelt management. On the one hand, it is recognised that institutions and stakeholders strongly influence environmental policy formation and implementation (Briassoulis, 2004). However, as outlined earlier, greenbelts are rarely analysed from a regional governance or institutional perspective in academic debates. In this research, I seek to address these key literature gaps. Therefore, the main research question for this dissertation is:

How do institutional arrangements shape the governance of regional greenbelts and how could these greenspaces be more effectively governed?

This research question seeks to identify the institutional structures that shape the interaction of stakeholders involved in managing greenbelts and to examine how institutional constraints impact greenbelt governance and policy implementation. This question also aims to provide recommendations for policy and institutional reforms. Thus, to answer this main research question, the following four questions were formulated:

1. How can an understanding of regional greenbelts be advanced through a political ecology approach?

My research applies an UPE lens to better understand what greenbelts are and how they are produced and reproduced. Chapter 2 uses a UPE perspective to examine the changing relationships between nature and urban society, as seen through greenbelt planning. In addition, it discusses how greenbelts can be seen as transitional zones between urban and rural spaces, with the suburbs serving as the mediating landscape within that context. 


\section{How does regionalisation shape the governance and planning of greenbelts?}

As regional institutional and governance arrangements have become increasingly complex in recent decades, the dynamics of regionalisation have similarly become more complicated. As discussed earlier, urban regions are now often spatially fragmented landscapes strongly shaped by a regionalised division of labour and service industries, with economic networks stretching far beyond territorial borders. In additional, population growth and suburbanisation at a regional scale often result in the conversion of natural areas for development uses. Thus, the aim of this research question is to examine how regionalisation influences the governance and planning of new generation greenbelts.

More specifically, the regionalisation of environmental policy is explored in both cases. In chapter 2, I discuss how the establishment of Southern Ontario's greenbelt can be seen as an upscaling of urban-regional regulation to a new policy level: The Greater Golden Horseshoe. However, in the Frankfurt case (chapters 4 and 6), a similar regionalisation of environmental policies has not occurred, with activities restricted local scale. In addition, suburbanisation at a regional scale in both cases puts intense development pressures on regional greenbelts, influencing the effective management of these greenspaces. In the Ontario case (chapters 3, 5 and 6), my research explores how development politics in areas beyond the GGH greenbelt impacts policy implementation. Chapters 4 and 6 discuss how Regionalpark implementation can be vulnerable to the Frankfurt region's growth politics.

3. How is greenbelt implementation coordinated across multiple territorial jurisdictions, policy domains and policy levels?

The aim of this research question is to analyse how institutions shape the implementation of greenbelt policies, through the dimensions of vertical, horizontal, and territorial coordination. In recent decades, the governance challenges and delivery of public services has become more complicated within urban regions as a diversity of private and civil society stakeholders are now involved, requiring new forms of coordination. Thus, it can be assumed that these conditions have the potential to impact greenbelt implementation. In addition, as discussed earlier, new generation greenbelt management requires coordination across diverse policy fields, between multiple policy levels and across numerous territorial jurisdictions. Therefore, it can also be assumed that managing these complex interactions between the different stakeholders and institutions involved in greenbelt management could create coordination problems. Thus, chapter 2 examines the first five years of greenbelt policy implementation within the $\mathrm{GGH}$ region and analyses initial coordination challenges across policy levels, policy domains and territorial jurisdictions. Chapters 4 and 5 discuss horizontal, vertical, and territorial institutional coordination problems in each case 
to explore the specific governance challenges involved in greenbelt implementation in each region. Finally, chapter 6 provides a comparative analysis of the GGH and the Frankfurt Rhine-Main greenbelts along these three institutional dimensions.

4. What lessons could be drawn for the future governance and planning of regional greenbelts?

The aim of this research question is to explore strategies that could develop more effective governance arrangements to support regional greenbelt planning and implementation. As many years have passed since both greenbelts were established, it is now possible to examine the effectiveness of their policies and see what lessons could be drawn for policymakers. Chapters 4 and 5 outline small-scale strategies that can be made within the existing institutional arrangements in the GGH and Frankfurt Rhine-Main regions, along with proposals for institutional reforms that could improve policy implementation in both cases. Finally, based on results from both cases, chapter 6 provides general recommendations on how to improve the governance of new generation greenbelts.

\subsection{RESEARCH DESIGN}

This dissertation uses a qualitative research design based on both inductive and deductive approaches. Qualitative research involves a process that begins inductively to identify the theories and data relevant to the study, followed by deductively gathering more information to further the analysis (Creswell and Creswell, 2018). Thus, in qualitative research, some phases of the research process may shift as the researcher starts to collect data and delves deeper into the topic to form a comprehensive picture of the issue being studied (ibid.). Qualitative research promises to provide heuristic insights, since it allows for an examination of complex social phenomena and an investigation of complex variables. A qualitative approach is therefore appropriate to study the regional governance of greenbelts and to answer the research questions outlined above. This involves exploring the diverse viewpoints from a range of stakeholders to understand how complex processes shape greenbelt management.

Case studies were selected as a methodology for this research. Case studies can be defined as an "empirical method that investigates a contemporary phenomenon (the "case") in depth and within its real-world context" (Yin, 2018, 15). In addition, case study research involves a research cycle with both inductive and deductive processes. Theory is initially explored by studying the case, and that information is then used to generate new concepts to explain what is observed. These new concepts are further refined through ongoing 
study of the case (Baxter, 2008). Within case study methods, the phenomena being examined is not easily separated from the context (Yin, 2018). As my dissertation focuses on analysing the governance of greenbelts from an institutional perspective, I explore diverse stakeholder relations which cannot be done in a laboratory setting. Instead, this research is context-specific, as each case involves different aspects that are important to understand how regional greenbelt governance functions in each location.

For my research, I selected a comparative case study design which involves examining regional greenbelt policy implementation in the GGH and Frankfurt Rhine-Main regions. A comparative case study design allows for a broader basis to test theory, helps to explain phenomena in different contexts, and provides opportunities to modify and refine theories as a result of commonalities and differences observed between cases (Yin, 2018). This research responds to the call for comparative perspectives that are now at the centre of critical urban studies (McFarlane, 2010; Robinson, 2016, 2011). In my research, the dependent variables are the governance challenges involved in greenbelt policy implementation, while the independent variables are the institutional arrangements explaining these governance complexities. Applying these variables comparatively allows for an examination of how the effectiveness of greenbelt policy outcomes depends on the institutional arrangements and governance structures supporting them. In addition, a comparative analysis of policy outcomes through an institutional perspective on the governance of regional greenbelts can provide policymakers with recommendations about how these greenspaces could be more effectively managed in the future.

\subsubsection{Data collection and methods}

For this dissertation, several qualitative research methods were used including conducting literature reviews, expert interviews, document analysis, site visits to both greenbelts, and attendance at public meetings, which are discussed below.

\section{Literature Reviews}

I reviewed relevant academic literature related to urban political ecology, smart growth, and greenbelts, including the history of greenbelt planning, growth management practices and greenbelt policy evaluation. In addition, I examined regional governance debates, particularly literature discussing regional planning, policy, politics, and institutional perspectives. These academic debates formed the basis for the dissertation's conceptual framework and the literature reviews outlined in chapters 2 to 6. 


\section{Interviews}

One of the main research methods I used were expert interviews. In total, I conducted 84 interviews for this research: 44 in the Ontario case and 40 in the Frankfurt case. These semi-structured interviews lasted between 30 minutes and two hours. The majority of the interviews were held in person, but I also did some interviews by phone or email due to logistical reasons. In addition, researchers of the Global Suburbanisms project, including Roger Keil, Kathryn Travis, and Lucy Lynch, participated in some interviews between 2013 and 2017. Interview participants were selected to represent all major stakeholder groups involved in greenbelt management in both cases, particularly the individuals responsible for each greenbelt's establishment. In addition, given the broader interest in understanding regional governance practices and suburbanisation in both cases, the interviewees selected were experts in those fields. Participants were initially selected via recommendations from colleagues in Ontario and Frankfurt and later through snowball sampling based on suggestions from interviewees. Therefore, expert interviews were held with representatives from municipal, regional, provincial, and state governments, nature conservation authorities, universities, along with environmental, agricultural, and home building organisations. In addition, I focused on selecting civil society groups and industry associations with a large membership, so that the interviewee could thus convey the broader interests of numerous stakeholders in our discussion. Within the relevant organisations, I also tried to select, when possible, specific individuals who had a long history of professional involvement with greenbelt planning in each case. See Appendices A and B for a list of interview participants.

The interview questions had an open-ended format and were modified slightly based on each participant's institutional affiliation or the themes that needed to be addressed in that conversation. Before each interview, I explained the purpose of the research to the interviewee, that their participation was voluntary, promised to keep their identity anonymous, and noted that the information obtained during the discussion would be confidential. For this reason, in all chapters, only general reference was made to the participants' position titles and institutional affiliations. The topics discussed during the interviews varied according to the different fieldwork phases and what empirical material was needed to prepare each article. However, the main topics covered during the conversations included each greenbelt's establishment and management, institutional arrangements, governance, land-use planning and nature conservation practices in both cases. All interviews were audio recorded and notes were taken during each meeting. The transcribed interviews were coded using MAXQDA software based on codes applicable to my research, such as the institutional dimensions from my conceptual framework, relevant policy domains (e.g. farming, housing, nature conservation and recreation), and topics specific to each case, including leapfrog development and landscape planning. In the Frankfurt case, all interviews were conducted in English except for one conversation, which was facilitated by a translator. 


\section{Document and Policy Analysis}

To contextualise the data collected through the interviews, policy documents and other empirical literature was analysed throughout this research. Policy documents such as land-use plans, landscape plans and other government reports were reviewed, along with newspaper articles, greenbelt promotional material and non-governmental organisation reports.

\section{Site Visits}

For this research, I conducted a total of 19 site visits to key locations within both greenbelts: seven in the Ontario case and 11 in the Frankfurt case. These site visits occurred between 2009 and 2018, lasting between two to four hours each. These field visits were important to contextualise the greenbelt policies and to see first-hand some of the issues involved in greenbelt management, such as leapfrog development. In addition, some of these visits were led by civil society group members, which provided a valuable perspective on the challenges related to greenbelt planning that they experienced.

\section{Public Meetings}

In Ontario, I attended approximately 25 public events related to the Greenbelt and Growth Plans between 2004 and 2017. These meetings included public consultations held by the Ontario government when relevant land-use policies were being introduced or reviewed. In addition, I attended events held by non-governmental organisations, such as Environmental Defense and the Friends of the Greenbelt Foundation, about topics related to the greenbelt or regional growth. These events were important for understanding greenbelt governance, as it let me see how stakeholders' opinions about this greenspace evolved over time. These meetings also allowed me to meet potential interview participants and to learn about current issues related to greenbelt planning.

\subsubsection{Research timeframes}

This research focuses on the 15-year time period from 2003 to 2018 in the GGH region, under the authority of a Liberal provincial government. Additional recent material has been added to chapters 4 and 6 or to the conclusion as needed. The Frankfurt case has a comparable research timeframe from 2005 to 2018, beginning with the creation of a regional greenbelt agency and ending with the completion of my fieldwork.

In the Ontario case, there were four main time periods of data collection. From August to October 2014, research was conducted on suburbanisation in the GGH region in relation to its greenbelt. In February and March 2017, I performed research on issues of farmland preservation and land speculation in Brant County, Ontario. The third fieldwork phase occurred in October 2017 when interviews focused on the outcomes of the 2015 review 
of the Greenbelt and Growth Plans. Finally, from August to December 2018, I did research on themes of institutional coordination and developments since the revised Greenbelt and Growth Plans were released in 2017.

In the Frankfurt case, I conducted fieldwork in three research phases starting in 2017. In September 2017, I conducted a scoping visit to Frankfurt for one week to obtain background information on the state of the case at that time, and to identify stakeholders to interview on subsequent trips. I made a second trip to the region in November and December 2017 for three weeks, collecting more information on the Frankfurt greenbelt, the Regionalpark, and the Frankfurt Rhine-Main region's spatial planning system. I made a final one-week trip in May 2018, focusing on collecting information related to institutional coordination, landscape planning, and nature conservation.

\subsubsection{Case study selection}

The case studies for this research were selected based on several similarities and differences related to both greenbelts and regions where these greenspaces are situated. First, these case studies were selected due to the commonalities and differences between the GGH and Frankfurt Rhine-Main regions. These two regions have geographical and governance similarities to anchor this research. Both global city-regions are the financial centres of their respective countries and are the focus of regional and national economic, cultural, and political development (Keil et al., 2017). These regions are characterised by strong demographic growth, stressed natural environments, housing affordability problems and have international airports serving as major transportation and employment nodes (ibid.). These regions also share several common governance characteristics, including being part of federal countries, histories of contentious institutional reforms, weak regional identities, problems with cooperation on regional issues, power asymmetries between a central city (i.e. Toronto or Frankfurt) and their surrounding municipalities, and fragmented public service provision (Nelles, 2012).

Despite these similarities, the GGH and Frankfurt Rhine-Main regions have different institutional environments, which has implications for each greenbelt planning model. Ontario has a two-tiered government structure including the provincial government and a municipal level divided between upper, lower, and single tier municipalities. Due to their constitutional standing, municipalities in Ontario have limited autonomy and access to major revenue sources, with the main responsibility for municipal affairs being under the jurisdiction of the provincial government (Côté and Fenn, 2014). In contrast, the Frankfurt region's institutions include municipalities, inter-municipal authorities at various regional scales and a two-tiered state government (Land). German cities also have a higher degree of autonomy compared to Canadian municipalities, as German constitutional law allows 
them extensive autonomy in spatial planning and partial control over property and business taxes (Monstadt and Meilinger, 2020). These differences in the cases' institutional contexts are important for my research, as this significantly impacts the effective governance of regional greenbelts and its policy outcomes.

In addition, each case has a different history of metropolitan regions, which has implications for the concepts applied in this research. In the Ontario case, the term metropolitan is historically linked to the second-tier local government of Metropolitan Toronto that was established in 1953 (Boudreau et al., 2007). However, as Metro Toronto was amalgamated in 1998 and Canada does not have metropolitan entities, the term regional is used within this case. In contrast, Germany has nine metropolitan regions, which were established over the past 20 years for spatial planning purposes and to enhance territorial competitiveness (Diller, 2016). Therefore, as metropolitan regions are not relevant within the Ontario case, this research uses the concept of regional governance.

Second, the case studies were chosen because the GGH greenbelt and Regionalpark share several common features. Both greenspaces have a regional spatial scope and their management is coordinated across multiple municipal and special purpose bodies' territorial jurisdictions. As examples of new generation greenbelts, they each have multifunctional policies that involve numerous policy fields and their related stakeholder groups. Their policies are set by provincial or state (Länder) levels of government with limited or no involvement from the national governments. Both cases are also located in federal states where the major authority for spatial planning and nature conservation laws are concentrated at the municipal, regional, and provincial policy levels. As each greenbelt has been established for several years, it is now possible to examine their policy outcomes and see how these greenspaces could be more effectively managed.

Finally, the case studies were chosen because they have two different institutional designs of greenbelt management. By examining the institutional differences between the cases, it is possible to more clearly identify how the governance challenges and opportunities involved in manging these greenspaces are shaped by institutional arrangements. The GGH greenbelt has a top-down approach to greenbelt planning whereby the Ontario government provides policy directions, which are then implemented by municipalities. In contrast, the Regionalpark has a more decentralised approach as it is managed by a special purpose body that operates as a public-private partnership, delegating implementation to municipalities. These different institutional arrangements for managing greenbelts are compared to examine how variations influence the governance of these greenspaces and their policy implementation. A detailed description of the case studies is presented in chapters 2 to 6 . However, I provide a brief introduction to each case below. 
The Greater Golden Horseshoe Greenbelt, Ontario

As the most densely populated region within Canada, the Greater Golden Horseshoe covers approximately 32,000 square kilometres with a total of 110 municipalities (Allen and Campsie, 2013) (see Figure 2.2). With a population of approximately 9 million residents in 2016, the region is one of the fastest growing in North America and is expected to grow to 13.5 million people by 2041 (Ministry of Municipal Affairs and Housing, 2019). The GGH region is recognised for its multicultural population, strong economy and for having some of Canada's most productive farmland.

In 2005, a Liberal provincial government (2003-2018) introduced legislation that declared approximately 720,000 hectares off limits for urban development. The Greenbelt Act allowed for the creation of a Greenbelt Plan, which was released by the provincial Ministry of Municipal Affairs and Housing in 2005. The Greenbelt Plan is designed to protect against the loss of natural heritage systems and farmland, to mitigate climate change and support rural communities' economic activities (Ministry of Municipal Affairs, 2017a). The GGH greenbelt includes a protected countryside, a natural heritage system and recreational trails (Figure 1.2).

The GGH greenbelt was designed to build upon earlier protected nature conservation areas such as the Niagara Escarpment and Oak Ridges Moraine, reflecting how the greenbelt planning and their governance have evolved over time. Protected since the 1970s by the Niagara Escarpment Planning and Development Act, the Niagara Escarpment is a ridge of limestone with unique geological and ecological systems that has been recognized by UNESCO as a world biosphere reserve. Considered as Canada's first large scale environmental land-use plan, the Niagara Escarpment Plan was released in 1985 with key policies including maintaining the escarpment as a continuous landform, protecting ecological and geological areas and providing recreational opportunities (Ministry of Natural Resources and Forestry, 2017). Protected in 2001, the Oak Ridges Moraine has significant hydrological and environmental features including water resources, plant and animal habitat and agricultural areas that provide key ecological functions for GGH region (Ministry of Municipal Affairs, 2017b). The Oak Ridges Moraine Conservation Plan's policies are designed to protect the ecological and hydrological integrity of the moraine, ensure that the moraine is maintained as a continuous landform and to only allow development which is compatible with plan objectives (ibid.). Therefore, the Greenbelt Plan, Niagara Escarpment Plan and Oak Ridges Moraine Conservation Plan together identify where urbanization should not occur within the GGH and thus provide strong protection for region's agricultural and ecological features (ibid.). 


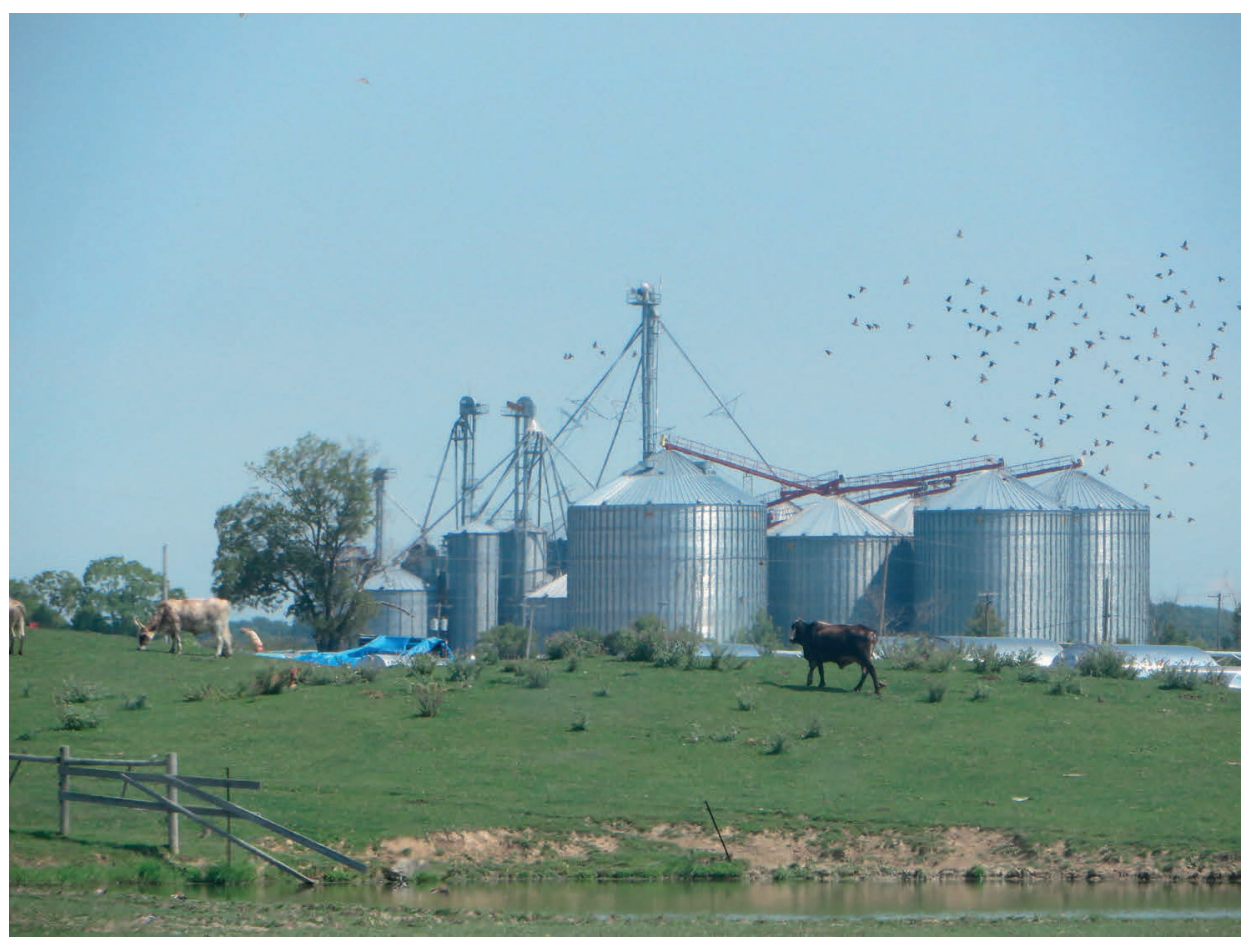

Figure 1.2: Farm within the GGH Greenbelt in Lincoln, Ontario (2014)

Source: author

\section{The Regionalpark RheinMain, Germany}

The Frankfurt Rhine-Main metropolitan region extends over three federal states (Länder), spanning an area of 14,800 square kilometres and includes 5.7 million residents (see Figure 4.2) (Regionalverband, 2018). At the centre of the metropolitan region lies the Greater Frankfurt area spanning 2,500 square kilometres, having 2.34 million residents and 75 municipalities including the cities of Frankfurt am Main, Wiesbaden, Offenbach, Mainz, Darmstadt, and Aschaffenburg (ibid.). The Greater Frankfurt region has grown by 138,000 residents in the past five years and is predicted to continue this population growth, with an additional 191,000 new residents expected by 2030 (ibid.). This region is strongly influenced by connections between its major cities through a regional division of labour and service industries, and it is also an international financial centre.

The implementation of the Regionalpark RheinMain is strongly shaped by the numerous levels of spatial planning policies of its member municipalities, the Regional Authority and state government (see Table 6.3). In the state of Hesse, the state development plan (Landesentwicklungsplan) outlines general spatial planning objectives, which 
are then specified in the regional plan for South Hesse (Regionalplan). While the state development plan hardly refers to the Regionalpark, the regional plan and, integrated with that regional plan, the Greater Frankfurt regionalised land use plan define priority areas (Vorranggebiete) for regional green corridors and for Regionalpark corridors. In these designated areas, priority must be given to green corridors which must not be impaired by other uses such as urban sprawl and further settlement development for residential and commercial uses. At the same time, changes in hydrological and climatic conditions or in the recreational functions of open space are not permitted here (Regionalverband, $2010)^{4}$. Despite these land use regulations, the state government, including its spatial planning authorities at the Länder and South Hesse levels, has limited involvement in greenbelt implementation. Based on its regionalised land-use and landscape plan for the 75 municipalities, the Regional Authority (Regionalverband FrankfurtRheinMain) is responsible for growth management the Greater Frankfurt area, and more broadly, for the governance of the Rhine-Main metropolitan region. While the Regional Authority is responsible for inter-municipal planning, provision for numerous public services within the Greater Frankfurt region such as water and waste services have been delegated to a range of special purpose bodies and voluntary associations (Hoyler et al., 2006). Similarly, apart from defining and enforcing land use restrictions through the priority areas, the implementation of the regional greenbelt has been delegated from the Regional Authority in 2005 to a special purpose agency: the Regionalpark Ballungsraum Rhein-Main GmbH.

Created in 1994 and currently spanning approximately 4463 square kilometres, the Regionalpark's goals include open space protection, promoting regional identity and providing recreational areas (Regionalverband, 2010) (see Figure 1.3). The park is managed by a special purpose agency that is structured as a public-private partnership with the company managing Frankfurt's airport, and its implementation coordinated by six intermunicipal implementation bodies that are responsible for developing sub-projects. The Regionalpark is formally protected in Regional Authority Frankfurt RhineMain's regionalised land-use and landscape plans, the regional plan for South Hesse and the Hessian State Development Plan.

The Regionalpark RheinMain was designed as a regional greenspace network that includes Frankfurt and Offenbach's greenbelts, the Nature Park Hochtaunus and the Hessische Ried agricultural area. Similar to the GGH greenbelt, the Regionalpark builds upon the previously protected nature conservation areas. Connecting greenspaces along the Main river, the

4 Deviations are only permitted for reasons of public welfare and if compensation areas of a similar size, quality and comparable function can be assigned to the priority areas of the regional green corridor (Regionalverband, 2010). 
Offenbach green ring (Grünring) has been protected since the city's 1984 land-use plan and has been included as part of Regionalpark RheinMain in 2000 (Stadt Offenbach, 2017). The aim of the policies protecting the green ring include developing a continuous green corridor that links open spaces to the city and the river, providing leisure opportunities and connecting to regional greenspaces (ibid.). Protected in 1991, the Frankfurt greenbelt (Grüngürtel) is an 8000-hectare greenspace that forms a 70-kilometre belt around the city. The Frankfurt greenbelt is protected by the city's "GreenBelt constitution", with a key policy being to refrain from development within this greenspace. However, if land is removed, the individual or company responsible must compensate for that development by adding land of the same size and quality to the greenbelt elsewhere (Husung and Lieser, 1996). In addition, the greenbelt is strongly protected under inter-municipal and state spatial planning and nature conservation regulations, making it difficult to make land-use changes within this greenspace.

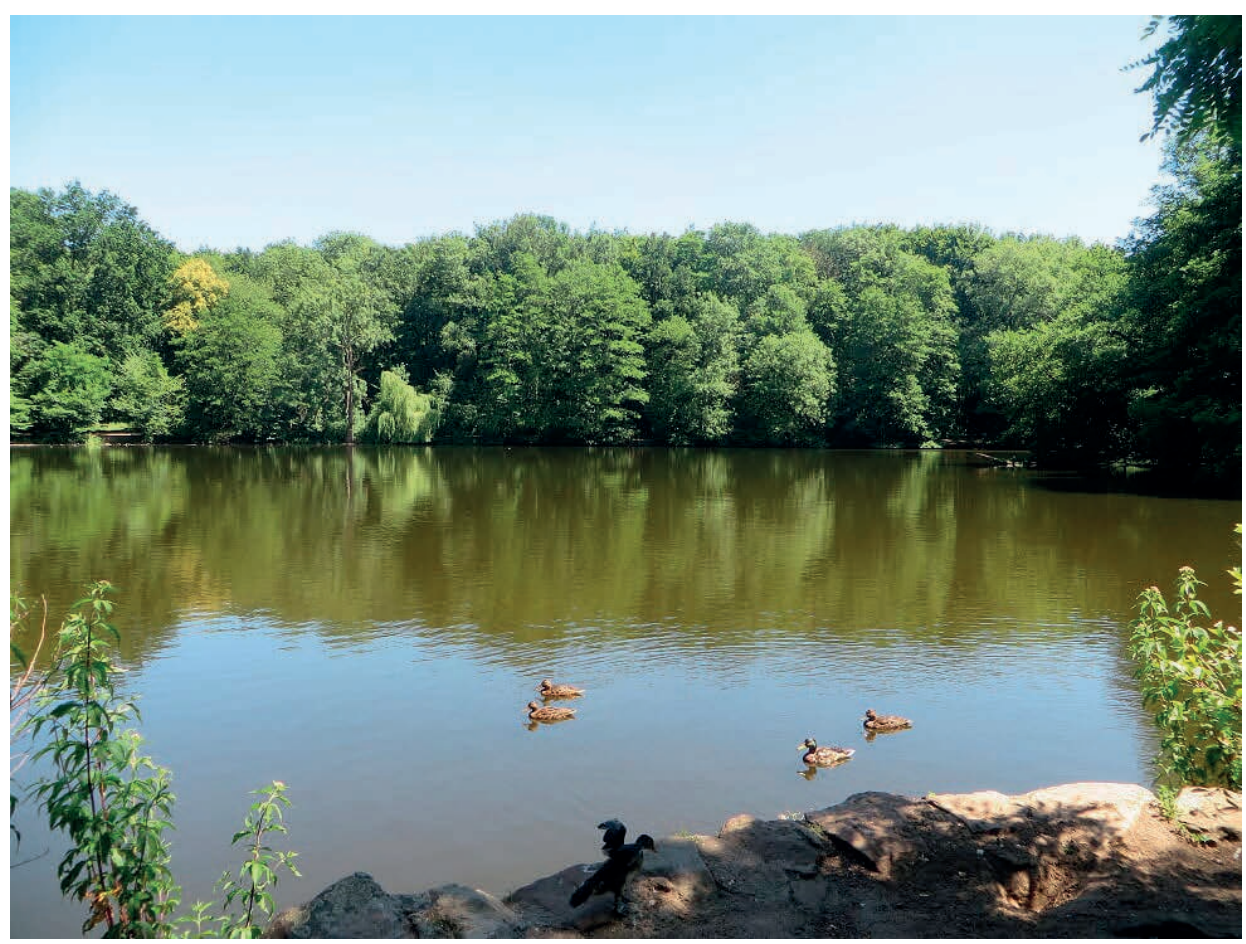

Figure 1.3: Lake within the Frankfurt Greenbelt (2015)

Source: author 


\subsection{STRUCTURE OF THE DISSERTATION}

This dissertation consists of seven chapters. Chapters 2 to 6 are based on journal articles that have been published or are under review in peer-reviewed journals. The organisation of this dissertation is briefly described below. Chapter 2 uses an urban political ecology lens to gain a better understanding of what greenbelts are and how they are produced and reproduced, through the GGH greenbelt policies ${ }^{5}$. Next, chapters 3 to 6 each examine different institutional dimensions of regional greenbelt governance. Theoretically guided by debates on new regionalism and state rescaling, chapter 3 examines the governance challenges faced in the first five years after the GGH greenbelt's introduction and how its policies shifted the scales of growth management in Southern Ontario. A similar conceptual framework of three institutional dimensions that impact regional greenbelt governance is applied to the Ontario and Frankfurt cases in chapters 4 and 5, which sets up the comparative analysis of both cases presented in chapter 6 . Chapter 4 explores the institutional complexities and governance challenges of upscaling a localised greenbelt to the regional scale in the Frankfurt Rhine-Main region. Chapter 5 examines the coordination problems and political challenges involved with smart growth policy implementation in Ontario. Chapter 6 introduces a typology of greenbelts and compares governance challenges of new generation greenbelt management in the GGH and Frankfurt RhineMain regions. Finally, chapter 7 draws overall conclusions from the research findings, provides theoretical reflections along with policy recommendations, and outlines avenues for future research.

5 It should be noted that chapter 3 was written before chapter 2. During the time between those two chapters, there was a change in leadership in the Ontario provincial government, stakeholders' attitudes towards the GGH greenbelt evolved and some regional planning policies were amended, influencing the discussions presented in chapter 2 . 


\subsection{REFERENCES}

Addie, J.-P. (2017). Governing the networked metropolis: The regionalisation of urban transportation in Southern Ontario. In Keil, R., Hamel, P., Boudreau, J. A., \& Kipfer, S. (Eds.). Governing cities through regions: Canadian and European perspectives. (pp. 121-142). Waterloo, ON: Wilfrid Laurier University Press.

Addie, J. P., \& Keil, R. (2015). Real existing regionalism: The region between talk, territory and technology. International Journal of Urban and Regional Research, 39(2), 407-417.

Aguado, I., Barrutia, J. M., \& Echebarria, C. (2017). Greenbelts: Some European experiences. Boletin de la Asociación de Geografos Españoles, (73), 463-467.

Alcantara, C., Broschek, J., \& Nelles, J. (2016). Rethinking multilevel governance as an instance of multilevel politics: A conceptual strategy. Territory, Politics and Governance, 4(1), 33-51.

Allen, A. (2014). Peri-urbanization and the political ecology of differential sustainability. In Parnell, S. and Olfield, S. (Eds.). Routledge handbook on cities of the Global South. (pp. 522-38). New York, NY: Routledge.

Allen, R. and Campsie, P. (2013). Implementing the growth plan for the Greater Golden Horseshoe. Has the strategic regional vision been compromised? The Neptis Foundation. Retrieved from http://www.neptis.org/publications/implementing-growth-plan-greater-golden-horseshoe

Allmendinger, P., Chilla, T., \& Sielker, F. (2014). Europeanizing territoriality-towards soft spaces?. Environment and Planning A, 46(11), 2703-2717.

Amati, M. (Ed.). (2008). Urban green belts in the twenty-first century. Hampshire, England: Ashgate.

Amati, M., \& Taylor, L. (2010). From green belts to green infrastructure. Planning Practice \& Research, 25(2), 143-155.

Angelo, H., \& Wachsmuth, D. (2015). Urbanizing urban political ecology: A critique of methodological cityism. International Journal of Urban and Regional Research, 39(1), 16-27.

Balz, V. and Zonneveld, W. (2020). The institutionalisation of a creative practice: Changing roles of regional design in Dutch national planning. In Lingua, V., Blaz, V. (Eds.). Shaping regional futures. Designing and visioning governance rescaling. (pp. 17-42). Cham, Switzerland: Springer.

Baxter, J. (2006): Case studies in qualitative research. In I. Hay (Ed.). Qualitative research methods in human geography. (pp. 81-97). Oxford, England: Oxford University Press.

Belina, B. and Lehrer, U. (2017). The global city-region. A constantly emerging scalar fix. In Keil, R., Hamel, P., Boudreau, J. A., \& Kipfer, S. (Eds.). Governing cities through regions: Canadian and European perspectives. (pp. 83-97). Waterloo, ON: Wilfrid Laurier University Press.

Benz, A. (2001). From associations of local governments to "regional governance" in urban regions. German Journal of Urban Studies, 40(2), 55-71.

Boudreau, J. A., Hamel, P., Jouve, B., \& Keil, R. (2007). New state spaces in Canada: Metropolitanization in Montreal and Toronto compared. Urban Geography, 28(1), 30-53.

Breit, H. and Troja, M. (2003). Institutional change and social learning in environmental contexts: An introduction. In Breit, H., Engels, A., Moss, T. and Troja, M. (Eds.). How institutions change. Perspectives on social learning in global and local environments. (pp. 13-30). Leske + Budrich, Germany.

Briassoulis, H. (2004). The institutional complexity of environmental policy and planning problems: The example of Mediterranean desertification. Journal of Environmental Planning and Management, 47(1), 115-135. 
Burton, W. (2016). From greenspace to greenbelt: The role of civil society in landscape protection in the Toronto region. (Unpublished doctoral dissertation). University of Toronto. Toronto, Canada.

Carrus, G., Scopelliti, M., Lafortezza, R., Colangelo, G., Ferrini, F., Salbitano, F., Agrimi, M., Portoghesi, L., Semenzato, P. \& Sanesi, G. (2015). Go greener, feel better? The positive effects of biodiversity on the well-being of individuals visiting urban and peri-urban green areas. Landscape and Urban Planning, 134, 221-228.

Carter-Whitney, M. (2010). Ontario's greenbelt in an international context. Friends of the Greenbelt Foundation. Retrieved from https://www.greenbelt.ca/ontario_s_greenbelt_in_an_ international_context2010

Caruso, N., Pede, E., \& Saccomani, S. (2019). Regionalization processes and institutional transformations in the Italian metropolitan areas among crises and ambiguities. International Planning Studies, 1-14.

Connolly, C. (2019). Urban political ecology beyond methodological cityism. International Journal of Urban and Regional Research, 43(1), 63-75.

Cornea, N. L., Véron, R., \& Zimmer, A. (2017). Everyday governance and urban environments: Towards a more interdisciplinary urban political ecology. Geography Compass, 11(4), 1-12.

Côté, A. and Fenn, M. (2014). Provincial-municipal relations in Ontario: Approaching and inflection point. Institute on Municipal Finance and Governance. Retrieved from https://munkschool. utoronto.ca/imfg/uploads/275/1560_imfg_no_17_online_full_colour.pdf

Creswell, J.W. and Creswell, J. D. (2018). Research design. Qualitative, quantitative, and mixed methods approaches. ( $5^{\text {th }}$ edition). Thousand Oaks, CA: Sage Publications Ltd.

Diller, C. (2016). The development of metropolitan regions in Germany in light of the restructuring of the German states: Two temporally overlapping discourses. European Planning Studies, 24(12), 2154-2174.

Econometric Research Limited. (2012). Evaluating the economic benefits of greenbelt assets. Friends of the Greenbelt Foundation. Retrieved from https://www.greenbelt.ca/evaluating the_economic_benefits_of_greenbelt_assets

Erickson, D. L. (2004). The relationship of historic city form and contemporary greenway implementation: A comparison of Milwaukee, Wisconsin (USA) and Ottawa, Ontario (Canada). Landscape and Urban Planning, 68(2-3), 199-221.

Falleth, E. I., \& Hovik, S. (2009). Local government and nature conservation in Norway: Decentralisation as a strategy in environmental policy. Local Environment, 14(3), 221-231.

Fawcett, L. (2004). Exploring regional domains: A comparative history of regionalism. International Affairs, 80(3), 429-446.

Filion, P., \& Pulver, N. M. (Eds.). (2019). Critical perspectives on suburban infrastructures: Contemporary international cases. Toronto, ON: University of Toronto Press.

Filion, P., \& McSpurren, K. (2007). Smart growth and development reality: The difficult co-ordination of land use and transport objectives. Urban Studies, 44(3), 501-523.

Freestone, R. (2002). Greenbelts in city and regional planning. In Parsons, K., and Schuyler, D. (Eds.). From garden city to green city: The legacy of Ebenezer Howard. (pp. 67-98). Baltimore, MD: John Hopkins.

Fung, F., \& Conway, T. (2007). Greenbelts as an environmental planning tool: A case study of southern Ontario, Canada. Journal of Environmental Policy and Planning, 9(2), 101-117.

Gabriel, N. (2014). Urban political ecology: Environmental imaginary, governance, and the nonhuman. Geography Compass, 8(1), 38-48. 
Galland, D. and Harrison, J. (2020). Conceptualising metropolitan regions: How institutions, policies, spatial imaginaries and planning are influencing metropolitan development. In Zimmermann, K., Galland, D. and Harrison, J. (Eds.). Metropolitan regions, planning and governance. (pp. 1-24). Cham, Switzerland: Springer.

Gallent, N., Andersson, J., \& Bianconi, M. (2006). Planning on the edge. The context for planning at the rural-urban fringe. London, England: Routledge.

Gibbs, D. and Lintz, G. (2016). Environmental governance of urban and regional development-scales and sectors, conflict and cooperation. Regional Studies. 50(6), 925-928.

Glass, M. R. (2018). Navigating the regionalism-public choice divide in regional studies. Regional Studies, 52(8), 1150-1161.

Goetz, K. (2008) Governance as a path to government. West European Politics, 31(1-2), 258-279.

Gordon, V. (2007). Partners or competitors? Perceptions of regional economic development cooperation in Illinois. Economic Development Quarterly, 21(1), 60-78.

Grant, J. (2009). Theory and practice in planning the suburbs: Challenges to implementing new urbanism, smart growth, and sustainability principles. Planning Theory \& Practice, 10(1), 11-33.

Guney, K. M., Keil, R., \& Ucoglu, M. (Eds.). (2019). Massive suburbanization:(Re)building the global periphery. Toronto, ON: University of Toronto Press.

Guay, L. and Hamel, P. (2015). The environmental governance of Canadian city-regions: Problems, actions and challenges. In Jones, K. E., Lord, A., \& Shields, R. (Eds.). City-regions in prospect?: Exploring the meeting points between place and practice. (pp. 214-236). Montreal, QB: McGillQueen's Press-MQUP.

Hajer, M. (2003). Policy without polity? Policy analysis and the institutional void. Policy sciences, 36(2), 175-195.

Hall, P. A., \& Taylor, R. C. (1996). Political science and the three new institutionalisms. Political studies, 44(5), 936-957.

Han, A. T., \& Go, M. H. (2019). Explaining the national variation of land use: A cross-national analysis of greenbelt policy in five countries. Land Use Policy, 81, 644-656.

Hansen, H. K., \& Winther, L. (2010). The spatial division of talent in city regions: Location dynamics of business services in Copenhagen. Tijdschrift voor economische en sociale geografie, 101(1), 55-72.

Haughton, G., Allmendinger, P., Counsell, D. and Vingar, G. (2010). The new spatial planning. Territorial management with soft spaces and fuzzy boundaries. New York, NY: Routledge.

Hawkins, C. (2014). Competing interests and the political market for smart growth policy. Urban Studies, 51(12), 2503-2522.

Healey, P. (2005). On the project of 'institutional transformation' in the planning field: Commentary on the contributions. Planning Theory, 4(3), 301-310.

Healey, P. (2013). Circuits of knowledge and techniques: The transnational flow of planning ideas and practices. International Journal of Urban and Regional Research, 37(5), 1510-1526.

Heeg, S. (2017). Governing the built environment in European cities. In Keil, R., Hamel, P., Boudreau, J. A., \& Kipfer, S. (Eds.). Governing cities through regions: Canadian and European perspectives. (pp. 65-82). Waterloo, ON: Wilfrid Laurier University Press.

Heinelt, H., and Kübler, D. (Eds.) (2005). Metropolitan governance. Capacity, democracy and the dynamics of place. London, England: Routledge.

Heley, J. (2013). Soft spaces, fuzzy boundaries and spatial governance in post-devolution Wales. International Journal of Urban and Regional Research, 37(4), 1325-1348. 
Heynen, N. (2014). Urban political ecology I: The urban century. Progress in Human Geography, 38(4), 598-604.

Heynen, N., Kaika, M., \& Swyngedouw, E. (2006). Urban political ecology: Politicizing the production of urban natures. In Heynen, N., Kaika, M., \& Swyngedouw, E. (Eds.) In the nature of cities: Urban political ecology and the politics of urban metabolism. (pp. 1-19). London, England: Routledge.

Hohn, U., \& Neuer, B. (2006). New urban governance: Institutional change and consequences for urban development. European Planning Studies, 14(3), 291-298.

Hooghe, L, \& Gary, M. (2003). Unraveling the central state, but how? Types of multi-level governance. American Political Science Review, 97(2), 233-243.

Horak, M. (2012). Conclusion: Understanding multi-level governance in Canada's cities. In Young, R., \& Horak, M. (Eds.). Sites of governance: Multilevel governance and policy making in Canada's big cities. (Vol. 3). (pp. 339-370). Montreal, QB: McGill-Queen's Press-MQUP.

Hoyler, M., Freytag, T., \& Mager, C. (2006). Advantageous fragmentation? Reimagining metropolitan governance and spatial planning in Rhine-Main. Built Environment, 32(2), 124-136.

Huggins, R. and Thompson, P. (2018). Regional innovation and growth theory: Behavioural and institutional approaches. In Paasi, A., Harrison, J., and Jones, M. (Eds.). (2018). Handbook on the geographies of regions and territories. (pp. 116-129). Chelenham, UK: Edward Elgar Publishing.

Husung, S. and Lieser, P. (1996). GreenBelt Frankfurt. In Keil, R., Bell, D. and Wekerle, G. (Eds.), Local places in the age of the global city. (pp. 211-222). Montreal, QC: Black Rose Books.

Jonas, A. (2011). Post-suburban regionalism: From local politics of exclusion to regional politics of economic development. In Phelps, N. A., \& Wu, F. (Eds.). International perspectives on suburbanization. (pp. 81- 100). London, England: Palgrave Macmillan.

Keil, R. (2018). Suburban planet: Making the world urban from the outside in. Cambridge, UK: Polity Press.

Keil, R., Hamel, P., Boudreau, J. A., \& Kipfer, S. (Eds.). (2017). Governing cities through regions: Canadian and European perspectives. Waterloo, ON: Wilfrid Laurier University Press.

Koch, P. (2013). Overestimating the shift from government to governance: Evidence from Swiss metropolitan areas. Governance, 26(3), 397-423.

Konijnendijk, C. C. (2010). The role of forestry in the development and reform of green belts. Planning Practice \& Research, 25(2), 241-254.

Kortelainen, J. (2010). The European green belt: Generating environmental governance-reshaping border areas. Quaestiones Geographicae, 29(4), 27-40.

Kühn, M. (2003). Greenbelt and green heart: Separating and integrating landscapes in European city regions. Landscape and Urban Planning, 64(1-2), 19-27.

Le Meur, P.-Y., \& Lund, C. (2001). Everyday governance of land in Africa. Bulletin de l'APAD [en ligne] $22 \mathrm{np}$.

Mace, A. (2018). The metropolitan green belt, changing an institution. Progress in Planning, 121, $1-28$.

March, J. G., \& Olsen, J. P. (2011). Elaborating the "new institutionalism". In Goodin, R. (Ed.). The Oxford handbook of political science. (pp. 159-175). Oxford, England: Oxford University Press.

Matkin, D. S., \& Frederickson, H. G. (2009). Metropolitan governance: Institutional roles and interjurisdictional cooperation. Journal of Urban Affairs, 31(1), 45-66.

McFarlane, C. (2010). The comparative city: Knowledge, learning, urbanism. International Journal of Urban and Regional Research, 34(4), 725-742.

Metzger, J., \& Schmitt, P. (2012). When soft spaces harden: the EU strategy for the Baltic Sea region. Environment and Planning A, 44(2), 263-280. 
Meyer, S. M., \& Konisky, D. M. (2007). Adopting local environmental institutions: Environmental need and economic constraints. Political Research Quarterly, 60(1), 3-16.

Ministry of Municipal Affairs. (2017a). Greenbelt plan, 2017. Retrieved from http://www.mah.gov. on.ca/Page13783.aspx

Ministry of Municipal Affairs. (2017b). Oak ridges moraine conservation plan (2017). Retrieved from https://www.ontario.ca/page/oak-ridges-moraine-conservation-plan-2017

Ministry of Municipal Affairs and Housing. (2019). Growth plan for the Greater Golden Horseshoe, 2019. Retrieved from https://www.placestogrow.ca/index.php?option=com_ content\&task=view\&id=9\&/temid=14

Ministry of Natural Resources and Forestry. (2017). Niagara escarpment plan (2017). Retrieved from https://files.ontario.ca/appendix__nniagara_escarpment_plan_2017___oc-10262017.pdf

Monstadt, J. and Meilinger, V. (2020). Governing suburbia through regionalized land-use planning? Experiences from the Greater Frankfurt region. Land Use Policy. 91. 104300.

Moss, T. (2004). The governance of land use in river basins: Prospects for overcoming problems of institutional interplay with the EU Water Framework Directive. Land Use Policy, 21(1), 85-94.

Natural England and the Campaign to Protect Rural England. (2010). Green belts: A greener future. Retrieved from https://www.cpre.org.uk/resources/housing-and-planning/green-belts/ item/1956-green-belts-a-greener-future

Nelles, J. (2013). Cooperation and capacity? Exploring the sources and limits of city-region governance partnerships. International Journal of Urban and Regional Research, 37(4), 1349-1367.

Nelles, J. (2012). Comparative metropolitan policy: Governing beyond local boundaries in the imagined metropolis. London, England: Routledge.

Oberthür, S., \& Gehring, T. (2006). Institutional interaction in global environmental governance. Synergy and conflict among international and EU policies. Cambridge, MA: The MIT Press.

Paasi, A., Harrison, J., and Jones, M. (2018). New consolidated regional geographies. In Paasi, A., Harrison, J., and Jones, M. (Eds.). Handbook on the geographies of regions and territories. (pp. 1-20). Chelenham, UK: Edward Elgar Publishing.

Paasi, A., \& Zimmerbauer, K. (2016). Penumbral borders and planning paradoxes: Relational thinking and the question of borders in spatial planning. Environment and Planning A, 48(1), 75-93.

Peters, B. G. (2019). Institutional theory in political science: The new institutionalism. ( $4^{\text {th }}$ ed.). Cheltenham, England: Edward Elgar Publishing.

Peters, G. and Pierre, J. (2000). Governance, politics and the state. London, England: Macmillan.

Pond, D. (2009). Institutions, political economy and land-use policy: Greenbelt politics in Ontario. Environmental Politics, 18(2), 238-256.

Regionalverband $=$ Regional Authority FrankfurtRhineMain (2018). Regionales monitoring 2018. Daten und fakten - metropolregion FrankfurtRheinMain. Frankfurt.

Regionalverband (2010). Regionalplan Südhessen / regionaler flächennutzungsplan, allgemeiner textteil of October 17, 2010. Darmstadt.

Rhodes, R. A. W. (1996). The new governance: Governing without government. Political studies, 44(4), 652-667.

Robinson, J. (2011). Cities in a world of cities: The comparative gesture. International Journal of Urban and Regional Research, 35(1), 1-23.

Robinson, J. (2016). Comparative urbanism: New geographies and cultures of theorizing the urban. International Journal of Urban and Regional Research, 40(1), 187-199. 
Röhring, A., \& Gailing, L. (2005). Institutional problems and management aspects of shared cultural landscapes: Conflicts and possible solutions concerning a common good from a social science perspective. Leibniz-Institut für Regionalentwicklung und Strukturplanung eV (IRS). Leipzig, Germany.

Salet, W., Vermeulen, R., Savini, F., Dembski, S. (2015). Planning for the new European metropolis: Functions, politics, and symbols. Planning Theory and Practice, 16(2), 251-275.

Savitch, H. V., \& Vogel, R. K. (2000). Introduction: Paths to new regionalism. State and Local Government Review, 32(3), 158-168.

Scharpf, F. W. (1997). Games real actors play: Actor-centered institutionalism in policy research. Oxford, UK: Westview Press.

Schmid, C. (2018). Networks, borders, differences: Towards a theory of the urban. In Brenner, N. (Ed.). Implosion/explosions. Towards a study of planetary urbanization. (pp. 67-80). Berlin, Germany: Jovis.

Schulz, M., Söderbaum, F. and Öjendal, J. (2001). Introduction: A framework for understanding regionalization. In Schulz, M., Söderbaum, F. and Öjendal, J. (Eds). Regionalization in a globalizing world: A comparative perspective on forms, actors, and processes. Zed Books.

Sieverts, T. (2003). Cities without cities: An interpretation of the zwischenstadt. London, England: Routledge.

Smith, M. (2005). Institutionalism in the study of Canadian politics: The English-Canadian tradition. In Lecours, A. (Ed.). New institutionalism: Theory and analysis. (pp. 101-127). Toronto, ON: University of Toronto Press.

Soja, E. (2015). Accentuate the regional. International Journal of Urban and Regional Research, 39(2), 372-381.

Stadt Offenbach. (August 4, 2017). 30 Jahre Grünring Offenbach: Wegweisende Entscheidung gegen die Südumgehung. Retrieved from https://www.offenbach.de/leben-in-of/planen-bauenwohnen/gruene_stadt/regionale_routen/dreissig-jahre-gruenring-offenbach-7.8.17.php

Stead, D., \& Meijers, E. (2009). Spatial planning and policy integration: Concepts, facilitators and inhibitors. Planning Theory \& Practice, 10(3), 317-332.

Stoker, G. (1998). Governance as theory: Five propositions. International Social Science Journal, 50(155), 17-28.

Storper, M. (2014). Governing the large metropolis. Territory, Politics, Governance, 2(2), 115-134.

Sturzaker, J., \& Mell, I. (2017). Green belts: Past; present; future? London, England: Routledge.

Swyngedouw, E. (1996). The city as a hybrid: On nature, society and cyborg urbanization. Capitalism Nature Socialism, 7(2), 65-80.

Swyngedouw, E. (2004). Social power and the urbanization of water: Flows of power. Oxford, England: Oxford University Press.

Swyngedouw, E., \& Heynen, N. C. (2003). Urban political ecology, justice and the politics of scale. Antipode, 35(5), 898-918.

Swyngedouw, E., \& Kaika, M. (2014). Urban political ecology. Great promises, deadlock... and new beginnings? Documents d'anàlisi geogràfica, 60(3), 459-481.

Taylor, L. (2019). The future of green belts. In Scott, M., Galant, N. and Gkartzios, M. (Eds.). Routledge companion to rural planning. (1 $1^{\text {st }}$ ed.). (pp. 458-468). New York, NY: Routledge.

Taylor, Z. (2019). Shaping the metropolis: Institutions and urbanization in the United States and Canada. Montreal, QB: McGill-Queen's Press-MQUP. 
Tomalty, R. (2012). Carbon in the bank: Ontario's greenbelt and its role in mitigating climate change. David Suzuki Foundation. Retrieved from https://davidsuzuki.org/science-learning-centrearticle/carbon-bank-ontarios-greenbelt-role-mitigating-climate-change/

Tuçaltan, G. (2019). Waste and metropolitan governance as vehicles of eviscerating urbanism: A case from Ankara. Capitalism Nature Socialism, 1-15.

Tzaninis, Y., Mandler, T., Kaika, M., \& Keil, R. (2020). Moving urban political ecology beyond the 'urbanization of nature'. Progress in Human Geography. Online first edition.

Wachsmuth, D. (2012). Three ecologies: Urban metabolism and the society-nature opposition. The Sociological Quarterly, 53(4), 506-523.

Walsh, C., Jacuniak-Suda, M., Knieling, J., \& Othengrafen, F. (2015). Soft spaces in spatial planning and governance: Theoretical reflections and definitional ideas. Conference paper. Retrieved from https://3ftfah3bhjub3knerv1hneul-wpengine.netdna-ssl.com/wp-content/uploads/2018/07/ walsh-et-al.pdf

Wekerle, G. R., Sandberg, L. A., Gilbert, L., \& Binstock, M. (2007). Nature as a cornerstone of growth: Regional and ecosystems planning in the Greater Golden Horseshoe. Canadian Journal of Urban Research, 16(1), 20-38.

Westerink, J., Haase, D., Bauer, A., Ravetz, J., Jarrige, F., \& Aalbers, C. B. (2013). Dealing with sustainability trade-offs of the compact city in peri-urban planning across European city regions. European Planning Studies, 21(4), 473-497.

Willi, Y., Pütz, M., \& Müller, M. (2018). Towards a versatile and multidimensional framework to analyse regional governance. Environment and Planning C: Politics and Space, 36(5), 775-795.

Yin, R. K. (2018) Case study research and applications: Design and methods. Los Angeles, CA: Sage.

Young, O. R., King, L. A., Schroeder, H., Galaz, V., \& Hahn, T. (2008). Institutions and environmental change: Principal findings, applications, and research frontiers. Cambridge, MA: MIT Press.

Young, O. (2002). The institutional dimensions of environmental change: Fit, interplay, and scale. London, England: MIT Press.

Young, R., \& Horak, M. (Eds.). (2012). Sites of governance: Multilevel governance and policy making in Canada's big cities (Vol. 3). Montreal, QB: McGill-Queen's Press-MQUP.

Zimmer, A. (2010). Urban political ecology: Theoretical concepts, challenges, and suggested future directions. Erdkunde, 343-354.

Zimmer, A., \& Sakdapolrak, P. (2012). The social practices of governing: Analysing wastewater governance in a Delhi slum. Environment and Urbanization Asia, 3(2), 325-341. 


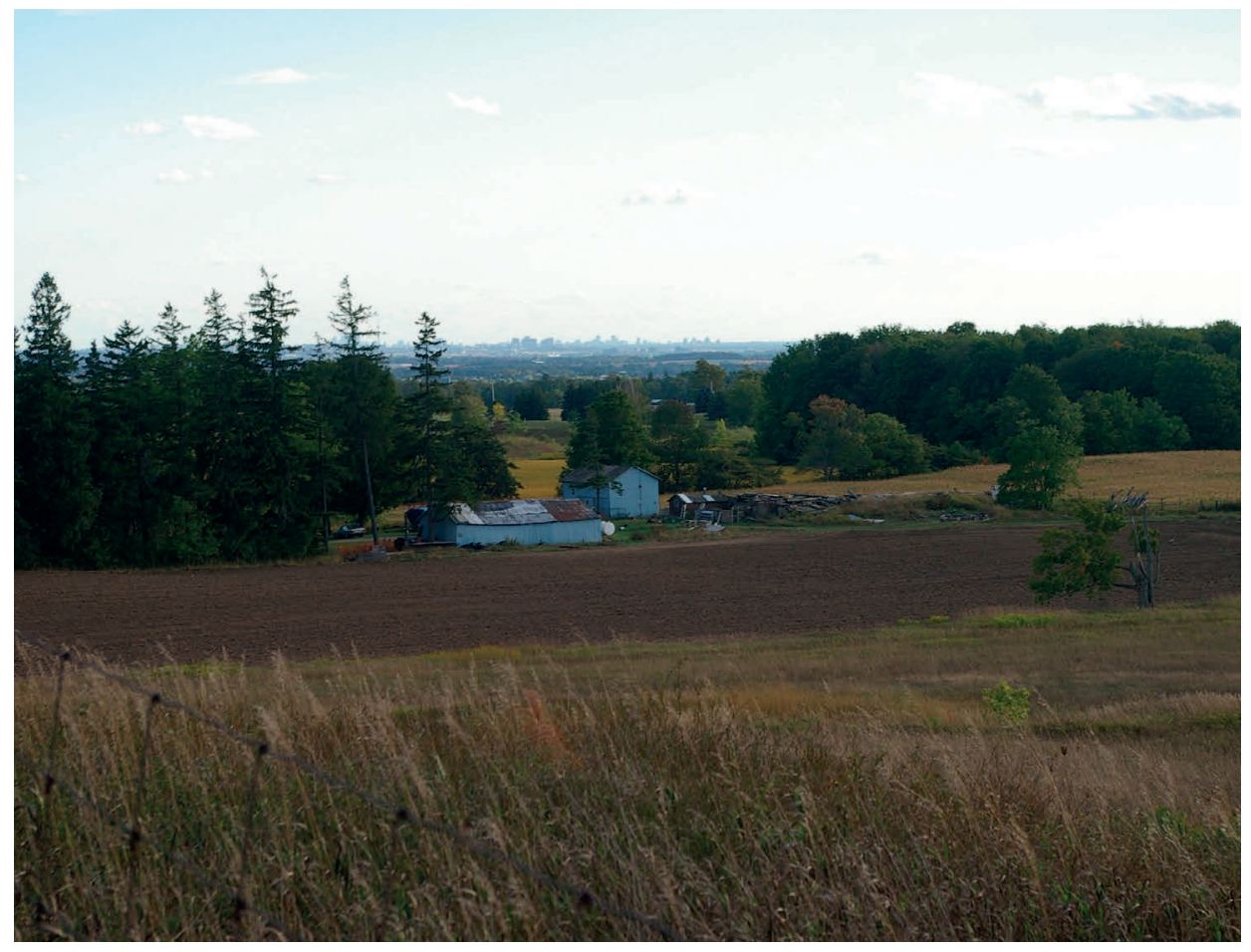

Looking from the Oak Ridges Moraine south towards Toronto (2007). Source: Roger Keil 


\section{Rethinking urban political ecology from the outside in:}

Greenbelts and boundaries in the post-suburban city

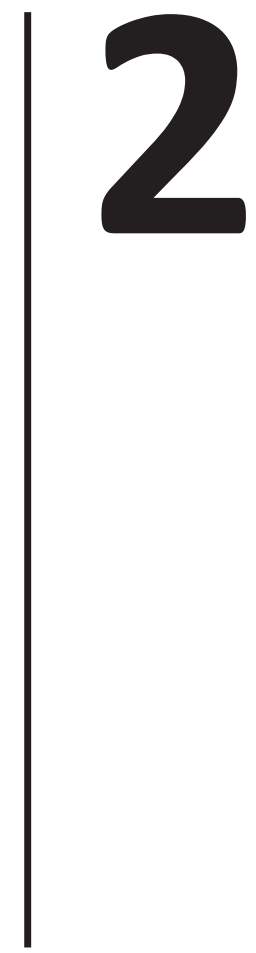

Published as Keil, R., \& Macdonald, S. (2016). Rethinking urban political ecology from the outside in: greenbelts and boundaries in the post-suburban city. Local Environment, 21(12), 1516-1533. Doi: 10.1080/13549839.2016.1145642 


\section{ABSTRACT}

This paper engages the existing literature on Urban Political Ecology (UPE) from the perspective of regulating urban expansion through greenbelts. The paper makes a contribution to a better understanding of suburbanisation and post-suburbanisation which have so far not been at the centre of the concerns of UPE. In an era of global suburbanisation, greenbelts differ from similar boundary setting exercises in the past and are as varied as the suburbanisation processes and their governance themselves. While conscious of those varieties, we focus here on the Greater Golden Horseshoe (GGH) greenbelt in Ontario that was created by provincial legislation in 2005. With the 2005 legislation, the Ontario government declared 720,000 hectares off limits for conventional urban development. The Greenbelt Act created an expansive area under protection from the Niagara Peninsula in the south to the Bruce Peninsula in the north, the Niagara Escarpment in the west to a series of moraines in the east. We will argue that the GGH greenbelt has become a prime negotiation space for the overall re-regulation of urban political ecologies in Southern Ontario. Largely surrounding the booming Toronto region, the GGH greenbelt is expansion space and projection screen of a suburbanizing region in search of redefinition.

\section{Keywords}

greenbelts, post-suburbanisation, urban political ecology, metabolism, boundaries 


\subsection{INTRODUCTION}

In this paper, we engage the existing literature on Urban Political Ecology (UPE) via the regulation of urban expansion through ostensible boundary setting. For our analysis, we focus on the instrument of a greenbelt, but we also glance at other examples of suburban boundary drawing and their significance for urban regions more generally. We treat this as an important frontier of global suburbanisation which we consider a defining feature of today's extensive urbanisation and part of the governance of suburbanisation (Hamel and Keil, 2015). Such boundary setting has been performed in mixed landscapes where suburbanisation proceeds. German planner Tom Sieverts (2003) has discussed various landscape-scaled boundary settings in his treatment of the Zwischenstadt, a term denoting an amorphous new metropolitan form that integrates urban, suburban and rural morphologies as well as open space. Sieverts incidentally had the Frankfurt and Ruhr regions on his mind when he coined the term, both sites of such boundarysetting exercises since the 1990s with the GreenBelt in Frankfurt and the Emscher International Building Exhibition in the Ruhr. The developmental dynamics of the boundary setting that greenbelts perform in an era of global suburbanisation are vastly different in various places as are the suburbanisation processes and their governance themselves (Friends of the Greenbelt Foundation, 2010; Hamel and Keil, 2015). In the booming Toronto region, the new greenbelt is an expansion space and projection screen where the global city is "going up the country" as Keil and Ronneberger (1994) once noted for Frankfurt. In the case of the Canadian oil town of Fort McMurray in Alberta, Shields (2012) discovers a particular "feral suburbanism" without much of a boundary between the vinyl suburban world of universal sub- divisions and the swamps of an unforgiving nature just beyond.

We will first discuss the merit of UPE literature which has now existed for two decades (Swyngedouw, 1996). We will argue that it has laid out a productive set of assumptions with which we can begin to understand the larger issues around boundaries and greenbelts in metropolitan areas today. The paper, in this sense, seeks to make a contribution to a better understanding of the UPE of suburbanisation and post-suburbanisation which has not been at the centre of the literature's concerns (for exceptions see the longstanding work by Andrew Jonas and Stephanie Pincetl on Southern California including Jonas et al. (2013) and Pincetl et al. (2011), as well as Keil and Graham (1998)). We will put forth the argument that the specific metabolic and discursive constellations engendered by massive suburbanisation and the accompanying attempts at limiting these expansions through environmentally themed and legitimised spatial boundary-setting exercises provide a prime lens through which to understand processes of post-suburbanisation and suburbanisation more generally.

Our eyes will be specifically on the Greater Golden Horseshoe (GGH) greenbelt. The Ontario government introduced strong legislation in 2005 that declared 720,000 hectares off limits 
for conventional urban development. The Greenbelt Act created an expansive area under protection from the Niagara Peninsula in the south to the Bruce Peninsula in the north, the Niagara Escarpment in the west to a series of moraines in the east. We will argue that the GGH greenbelt has become a negotiation space for the overall re-regulation of UPEs in Southern Ontario (Macdonald and Keil, 2012).

\subsection{UPE REVISITED}

Political ecology is an interdisciplinary field engaged in the critical analysis of environmental issues which has been established strongly in recent reviews and needs no detailed discussion here (Angelo and Wachsmuth, 2014; Heynen 2014; Keil, 2011a; Lawhon et al. 2014; Swyngedouw and Kaika 2014). UPE focuses on the urban and explores processes of urbanisation or "socio-nature" relationships with regards to urban environments (Swyngedouw, 1996). But, as Swyngedouw and Kaika (2014, 462-463) have noted, UPE is

"not so much concerned with the question of nature IN the city, but rather with the urbanization OF nature, that is, the process through which all types of nature are socially mobilized, economically incorporated (commodified), and physically metabolized/transformed in order to support the urbanization process." 6

6 We were asked to clarify our use of "nature" and "environment" in this article. This is obviously a larger task than can be addressed briefly in a footnote or paragraph. However, a few words are in order. Generally, we are bound to some degree through the use of the term by actors, policies, etc. that predate our analysis. This also includes the common usage in theoretical sources we consult. UPE speaks mostly to "nature" (like in the phrase "urbanisation of nature") and it refers to socionatural relationships above all. Our prime concern is with the reconceptualization of urban edges along the frontier of massive suburbanisation experienced in Southern Ontario. The "nature" encountered there is already layered by thousands of years of human presence. We use "nature" in this sense as, admittedly, a catch-all for human and non-human nature, bio-physical environment, the more or less greenfields, forests, streams, etc. around the settled area in Toronto. "Protecting agriculture" is not at the centre of this concern, neither for us as authors, nor for the authors of greenbelt legislation. It is not unimportant, but it is not central. In fact, one could (facetiously) argue that "agriculture" in any organic or green sense is sacrificed in much of the greenbelt as the agricultural areas there resemble the most industrialised forms of farming (soy, corn, Christmas tree farms) or gentrified ("horsfication", golf courses) land uses that may or may not deserve the monikers "green" or "nature". Nature is also not "public" in the GGH greenbelt, as it appears in Europe where greenbelts, wedges or fingers are often openly accessible to urban dwellers and where "into nature" includes this reference to public access. Instead, the GGH greenbelt is largely composed of privately owned land that opens itself to public access only through select hiking trails, for example. If not referring concretely to the surroundings of Toronto, "environment" is usually a political term as in environmental policy or environmental movement. 
UPE explores existing power relations and views cities as "historical products of humannature interaction" (Keil, 2003, 724). According to UPE "the ways in which urban environmental consumption, production, and exchange result in constant dialectical spatial reformation are helping to illustrate that urban metabolic force, propulsion, and agitation can never be seen as simply static circulations or simple recirculation" (Heynen, 2014, 600).

Some UPE literature has been focused on suburban issues of all kinds. Among them are critiques of ecological modernisation as a mechanism to accomplish growth goals in regions in articulation with conservation efforts. Certain policies or strategies, such as increased public transit access in suburbs, which on the surface appear to be eco-friendly, are part of "the hegemonic ecological modernization discourse [ ... and are] really generated as a thinly disguised attempt to create a better infrastructure for more sprawl" (Keil and Boudreau, 2006, 55). Suburban lawns - a product of human intervention: "grasses, weeds, and chemicals make us who we are" - have notably been subject to examination within a UPE framework (Robbins, 2007) as has the perceived "inside-outside" relationship between city and nature (Heynen et al. 2006; Swyngedouw 2006).

Very few contributions have, however, dealt directly with the kinds of boundary questions we focus on in this article. Urban areas have been conceptualised and defined as separate spaces, as "inside and outside, centrality and periphery, of town and countryside" (Keil and Graham, 1998, 103). This conceptualisation has been reproduced through time even though cities have always been built within nature, as cities are created by appropriating the natural environment to create urban environments where human populations continue to rely on nature through the practices of accumulation, consumption and reproduction. The articulation of nature in opposition to the urban has occurred since the medieval city where nature was physically separated from human populations through walls, gates, and trenches (ibid.). This spatial distinction of nature from the urban continued into the early industrial city and well into the Fordist city with its mass production and consumption apparatus. It appeared as if "agriculture [and nature] happens elsewhere" away from urban populations, with nature appearing as "a cultural artifact" (ibid., 105). After Fordism, nature has been more regarded as an intrinsic part of the urban; it is "no longer exiled from the city, but [has] become the key element of the current era of urban growth" (ibid., 107). Nature, in the form of the environment of and around the city, has become a fundamental element in institutional and legislative reforms regarding urban-regional development, which has manifested itself through various policy tools such as the use of greenbelts and other landscape regulations, flood control provisions, air and soil pollution policies, etc. (Desfor and Keil, 2004). 
The concept of "socio-nature" as put forth by Swyngedouw (1996) emerges from the rationale that nature is ubiquitous in the social realm, "while denying that nature can ever be independent of the social" (Wachsmuth, 2012,516). Urban environments have also been conceptualised by urban political ecologists as "assemblages of social and natural relationships" (Loftus, 2012, xxi). The critical UPE concept of metabolism, influenced by both political economy and biophysical science (Gandy, 2004), literally the "exchange of matter" in the German Stoffwechsel to which it lays root, is expressive of these assemblages (Girardet, 2008). Within the current literature, the dominant understanding of urban metabolism is expressed through socially regulated material flows such as energy and other matter (Gandy, 2004; Marvin and Medd, 2006; Pincetl et al. 2014). Urban metabolism has been understood as the "sum total of the technical and socioeconomic processes that occur in cities, resulting in growth, production of energy and the elimination of waste" (Kennedy et al., 2007, 44). Keil and Boudreau $(2006,43)$ assert that even though this traditional meaning of urban metabolism is useful, it has four "weakness[es] that need to be addressed": greater attention needs to be paid to political changes; a critique of capitalist socio-natural relationships needs to be included; there must be a focus on social issues; and nature needs to be viewed as dynamic and agentic. In a similar vein, Swyngedouw $(2006,106)$ proposes "to mobilise 'metabolism' and 'circulations as socio-ecological processes that permit framing questions of the environment and, in particular, the urban environment, in ways that are radically political". It is here that UPE conceptualises urban metabolism in a political manner.

\subsection{THE UPE OF GREENBELTS}

Our interest here is what contribution UPE can make to the theorisation of boundaries with the aggressive suburbanisation processes that define today's urban growth (Keil, 2013). To begin, UPE conceptualises the city as a sub-system located within a larger sociospatial system (an urban region), and the notion of metabolism highlights the interaction between and among multi-scalar systems (Heynen et al. 2006 in Wachsmuth 2012). To some critics of UPE's traditional mode of operation it appeared that UPE subscribes to a "unit-like" conceptualisation of urbanisation as "territorially discrete, bounded and selfcontained" (Brenner, 2013, 101), which has led to a "cityist" methodology (Angelo and Wachsmuth, 2014). Still UPE has been quite aware of the transnational and networked nature of metabolic flows and the relational nature that constitutes urbanity (Keil, 2011a, 2011b; Keil and Whitehead, 2012). 
We take, then, from the UPE literature, an interest in the urbanisation of nature, or rather suburbanisation of nature, which corresponds to an imbrication of the suburban with nature along perforated boundaries as we will discuss further below. The territorial boundary between greenbelt and suburbia separates and negotiates an increasingly complex set of productions of socio-natures that belie the original simplicity of the citycountry dichotomies in the earliest imaginaries associated with greenbelts in the UK. When talking about particular place-based metabolic relationships, we are always keenly aware of the scalar and topological relationships that define the metabolisms in a particular region. For example, immigrants to new suburbs, capital from abroad used to finance the building of subdivisions and commodities provided through the world market define the boundaries and perforations of metabolic relationships at the suburban frontier. But those metabolisms have to be stabilised and reproduced through local action under regional regulation where possible.

While we can imagine the metabolism of the urban region as a seamless web of human and non-human life with metabolic streams connecting organisms, we also must recognise the obstacles and facilitating channels by which those streams are conditioned and sustainabilities are fixed (Keil and Whitehead, 2012; Macdonald and Keil, 2012). The greenbelt, as a negotiated space of societal relationships of nature that connect urban and non-urban activities, becomes a canvas for the production of (social/urban) nature where suburbanisation and urbanisation are enclosed, enabled, and energised. The greenbelt faces a contradiction: it displays an ethics of enclosure; "the metaphor of the belt is one of control over flows" (Keil, 2011a, 30).

Metabolism is ultimately about the localisation of flows in specific socio-natural processes in situ (we can think of this in corporeal terms or in terms of technological systems). This may cast the process of urbanisation and suburbanisation in terms of how socionatural flows accommodate the built and social environment, undoubtedly leading to the exploitation of natural ecosystems while, in turn, nature is (discursively) preserved and (legally) protected. Greenbelts are an important planning mechanism as they not only control growth and flows, but they are also considered to be important landscapes for urban resilience. The concept of resilience needs to be understood "in terms of socioecological systems and that dynamic interactions between socio-economic and biophysical processes operate over multiple scales" (Buxton, 2011, 2).

In this context, greenbelts have been used not only as a planning tool to control urban growth and prevent sprawl but also to create green space for urban populations. As such greenbelts create a rural and urban divide (real and imagined). Greenbelts have taken hold in urban planning since the nineteenth century (i.e. Garden Cities), with Ebenezer Howard 
being the most prominent figure attached to the concept (Amati and Taylor, 2010, 143). It was within Britain that the concept of greenbelts was first fully realised. As a Keynesian instrument, it served the rationalisation of controls of urban growth and of housing development in non-greenbelt areas. Currently, the debate about British greenbelts has flared up as major housing needs are felt in the country's cities, especially in the London area, and arguments have been put forth that greenbelt restrictions should be loosened in order to meet those needs (Thompson, 2015). Germany also had an early greenbelt movement with Frankfurt as an important example from the 1920s where modernist housing projects under the direction of Ernst May were integrated into a comprehensive landscape plan along the city's two rivers. Internationally, the concept has taken hold globally with local variations such as "green wedges" in Australia (Buxton and Goodman, 2002) or through promoting urban agriculture in Tokyo as noted by Watanabe et al. (2008).

Today's greenbelts react to a different set of challenges than the ones encountered by planners in the 1920s and 1940s. Diversification of purposes in the greenbelt mirrors changing city-hinterland relationships and more differentiated socio-natures on both sides of the greenbelt boundary. Greenbelts are also now viewed frequently in terms of efficiency and economic value as is common in neoliberal societies. Within Southern Ontario, the GGH greenbelt is described as "a multifunctional space for agriculture, nature and settlement negotiated at the local municipal level" (Amati and Taylor, 2010, 147), and as with other greenspaces in or near urban areas it also provides "ecosystem services" (Pincetl, 2010). Greenbelts as multifunctional greenspaces for this reason can be understood as also having economic benefit, or "contributing to place competitiveness" (Thomas and Littlewood, 2010, 216). This is largely attributed to the fact that "ecosystems are seen as critical for sustainable economic growth and social goals, not just a way of supporting wildlife and 'the environment'" (Natural Economy Northwest, 2008, 2, in Thomas and Littlewood 2010, 216). The contemporary process of urbanisation is being envisioned as needing to be achieved "through nature and ecology rather than against it" (Keil and Graham, 1998, 108), as there are numerous associated social, economic, political and environmental benefits.

Undoubtedly, greenbelts have spread globally as a planning tool in contemporary environmental governance. There are many actors involved within a network to implement greenbelts, particularly researchers, government agencies and non-governmental organizations (Kortelainen, 2010, 31). Since the 1960s and 1970s governments have increasingly engaged non-governmental organizations and public-private partnerships through new arrangements of "technologies of governing", which is a response to "changing socioeconomic and cultural conditions" (Swyngedouw, 2005, 1992), in official and unofficial formation and implementation of policy often historically also referred to as 
the transition from the Keynesian, or welfare, state to the neoliberal state (Harvey, 2007). This transition has often been seen coincident with a shift from government to governance as "governance, unlike government, refers to policies rather than politics" (Pincetl, 2010, 49). In this reading of governance, the top-down approach of government is replaced by stakeholder-based arrangements "in which [the] traditional state forms partake with experts, NGOs, and other responsible partners" (Krueger and Gibbs, 2007 in Pincetl $2010,49)$. This approach is seen in all aspects of government administration including environmental planning and resource management. As such, organisations such as the Friends of the Greenbelt Foundation, the David Suzuki Foundation, Environmental Defense, along with other non-governmental organizations, conservation authorities and grass-roots community organisations are part of the "institutional arrangements of "governing" which give a much greater role in policy-making, administration and implementation to private economic actors on the one hand and to parts of civil society on the other in self- managing what until recently was provided or organised by the national or local [governments]." (Swyngedouw 2005, 1992).

Heynen and Perkins $(2005,107)$ assert that, since nature is "socially produced, urban political economy increasingly dictates that they are produced in accordance with market forces" where neoliberal environmental management "will likely lead to an increasingly uneven ecology" (ibid., 111) and therefore there are "contradictions of how neoliberalisation affects socio- natural relations at all scales" (ibid., 112). As the boundary between urban and nature is blurred (Keil, 2005), the neoliberalisation of environmental planning and resource management is redrawing the boundary between public and private environments; or eroding boundaries of "political territories, and physical spaces" (Monstadt, 2009, 1935). This distortion has ultimately led to challenges in defining traditionally understood boundaries (Kennedy et al., 2007).

\subsection{THINKING ABOUT POST-SUBURBANISATION}

Historically, urbanisation has been associated with the inside/outside problematic as settlement expansion boundaries have forever defined the urban (Keil and Shields, 2013). This is where the narrative of urbanisation is really one of suburbanisation. In the traditions of both the Chicago and Los Angeles schools of urban studies, the spatial negotiation of the city's edge received wide, if rather different, attention throughout the last century (Judd and Simpson, 2011). Teaford $(2011,15)$ reminds us, "suburbs have existed virtually as long as cities", and have been the space of desire and fear, freedom and displacement: "The fringe represented freedom from the city - the ability to do what was not allowed or impossible within the densely-populated core". From the fringe one can look both 
back towards the city and outward towards the world beyond. Here, suburbs appear as transitional zones, not yet entirely urban, but clearly not rural anymore. Historically, there are two archetypes in which this boundary is marked: the city edge or the sprawl. Boundaries in this context, as historic-spatial products of relationships between urban activities and non-urban activities, need to be rethought in a postsuburban world (Phelps and $\mathrm{Wu}, 2011)$. In post-suburbia, the rural and the urban are sublated into a new landscape of which city, boundary and fringe are mere elements.

Different boundary topologies in post-suburbia - freeways, rivers, farmland, and greenbelts - mesh in this landscape. Greenbelts, official reserves of agricultural or open space, appear as "thresholds" that have to be differentiated sharply from the conventional idea of boundary as "on the threshold two different spaces overlap" (Prigge, 1991). Far from being a hard line, the threshold marks a space for multiple negotiations that Barraclough, for instance, has examined in the "rural urbanism" of the San Fernando Valley in Los Angeles (Barraclough, 2011, 3). Having said that, we recognise that instruments of boundary setting between suburbanisation and its outside in Southern California are usually regional habitat conservation planning, growth control measures and development agreements. ${ }^{7}$

Land uses in the greenbelt change as the mode of production switches: what used to be associated with agriculture now serves as the basis for a spatial fix for the post(sub) urban-regional metropolis. Para-agriculture emerges with horse farms, trailer parks, Christmas tree plantations, apple picking farms and fall festivals. Today's greenbelts are not qualitatively different from the city but congealed conjugations of postsuburban relationships, temporary sedimentations of the confrontation of suburbanisation with its outside. They take shape in conversation with the push of the surrounding suburbs. The use of infrastructure in the greenbelt is no longer subject primarily to the primacy of agricultural pursuits, but by the interests of public and private actors who are based in the city in real and imagined green landscapes. Suburbanisation, through metropolitan governance, redefines boundaries establishing buffer zones (greenbelts, wedges, fingers, urban national parks). Greenbelt initiatives are now imposing themselves on the political discourses of a variety of urban areas around the world. In Toronto, such "threshold politics" include temporal boundaries between the modernism and industrialism of the previous period and the fragmented post-industrialism of the current period that are also now the spatial boundaries between different imaginaries in which the urban is refracted: is this golf course in the greenbelt urban, suburban or rural?

7 We thank one of our reviewers for reminding us of that fact. 


\subsection{THE GGH REGION}

Population and economic growth within the province of Ontario is concentrated in the so-called Greater Golden Horseshoe region (GGH). This urban region covers approximately 32,000 square kilometres (Figure 2.1) (Ministry of Infrastructure, 2013). The GGH is made up of a range of urban settlements including large cities such as Toronto and Hamilton, mid-sized cities and villages, hamlets, and altogether includes 110 different municipal jurisdictions (ibid.). The GGH is considered Ontario's economic engine, as it generates twothirds of the province's gross domestic product (ibid.). This is one of the fastest growing regions within North America, and of the 250,000 people who immigrate to Canada every year, about half of them choose to settle in the GGH (ibid.). This region was home to 8.76 million people in 2011, a number that is expected to grow significantly in the coming years (Statistics Canada, 2013). The Ontario government predicts that by 2041 the GGH could be home to 13.48 million people and 6.27 million jobs, accounting for more than $80 \%$ of Ontario's population growth (Ministry of Infrastructure, 2012).

Since the mid-1990s, consecutive provincial governments have introduced several changes to the land-use planning system in Ontario. Between 1995 and 2003, a Conservative government promoted low-density development within the province. They rewrote policies in order to remove previous efforts to curb urban sprawl or amended existing regulations with weakened language that was to the benefit of the development community. In 2001, however, under much public pressure including from new exurban movements in the conservative heartland, the government of the time adopted the Oak Ridges Moraine Conservation Act and Plan for the protection of this landscape. The Niagara Escapement Conservation Act that goes back to the 1970s and the Moraine Act would serve as the future basis for the GGH greenbelt.

Elected in 2003, a Liberal government under Premier Dalton McGuinty made several reforms that effected regional growth and development in the province. In 2006, they created the Greater Toronto Transportation Authority, now Metrolinx, which is responsible for improving the integration of regional transportation systems within the Greater Toronto Area and Hamilton, and in 2008, this agency released a regional transportation plan called "The Big Move" (see Metrolinx, 2008). Other changes to provincial planning policies included an emphasis on sustainable growth and development and giving local municipalities and the public more say in the planning process. However, the focus of this paper will be on two sets of policies that aim to rethink how people could live within the GGH in the coming years: the Greenbelt Act and the Places to Grow Act. 


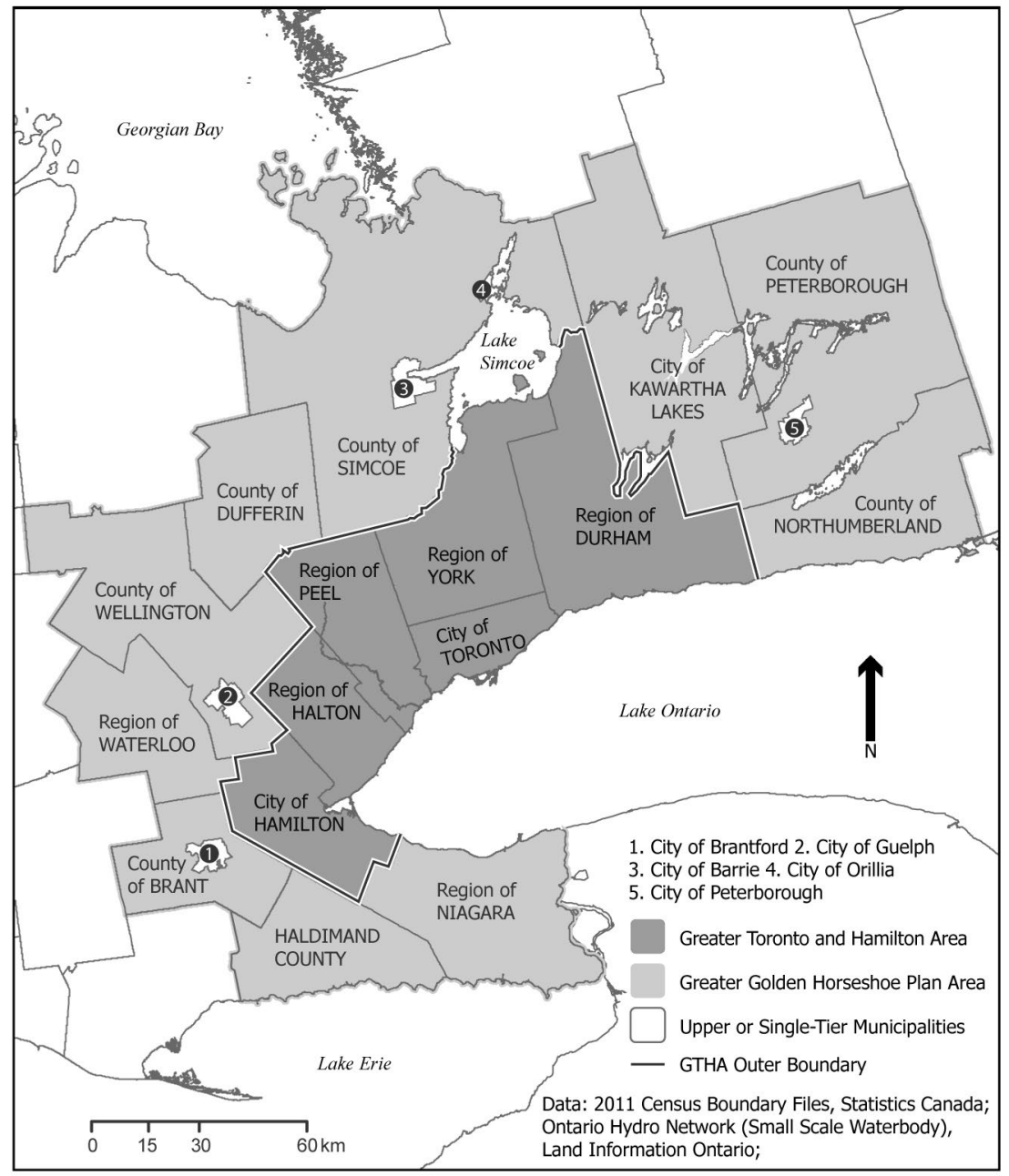

Figure 2.1: The Greater Golden Horseshoe Region

Source: Ministry of Infrastructure, 2006 


\subsection{THE GGH GREENBELT}

In their 2002 provincial election platform, the Liberal Party, led by Dalton McGuinty, promised that "we will protect the greenspace that surrounds our cities, forever" by promising to create a greenbelt that would permanently protect an additional 400,000 hectares of environmentally sensitive land in the GGH region (Ontario Liberal Party, 2002, 17-18). Right after they were elected in 2003, the Liberal government introduced Bill 21, the Greenbelt Protection Act, which placed an immediate one-year moratorium on development within a proposed greenbelt study area. ${ }^{8}$ During the moratorium, the Minister of Municipal Affairs and Housing (MMAH) appointed a 13-member Greenbelt task force and after public consultations, they made recommendations to the Minister on how planning the greenbelt should be approached. In February 2005, the Greenbelt Act was passed by Ontario's provincial government and this legislation allowed for the creation of a Greenbelt Plan, which was also released that year.

The GGH greenbelt is a permanently protected countryside that stretches from the Niagara Peninsula at the American border to Northumberland County north of Lake Ontario. Billed as the largest permanently protected greenbelt in the world, the GGH greenbelt contains areas that were previously preserved under the Niagara Escarpment Plan and the Oak Ridges Moraine Conservation Plan (Figure 2.2) (Friends of the Greenbelt Foundation, n.d.). The greenbelt was designed to protect against the loss of farmland, natural heritage and water resource systems and to support the economic and cultural activities associated with rural communities (MMAH, 2005). The plan generally prohibits the designation of protected areas for development purposes, prevents development close to environmentally sensitive areas and promotes the creation of recreational spaces. The greenbelt features a diverse range of land uses and activities. Agriculture is a primary land use in the greenbelt, as $43 \%$ of the total area within the greenbelt was used for agricultural purposes in 2011. There were over 5500 farms in the greenbelt in 2011, which represents $7 \%$ of all farms in the province (JRG Consulting Group, 2014). The greenbelt helps to preserve some of the most significant agricultural land in the country and it protects valuable specialty crop areas such as the Niagara Peninsula Tender Fruit and Grape Area (known for its ice-wine) and Holland Marsh (known as Ontario's vegetable basket) (Friends of the Greenbelt Foundation, n.d.). The greenbelt's natural heritage system covers 216,000 hectares of wetlands, lakes, river valleys and forest, while providing habitat for 78 species at risk (ibid.). Also, a $475 \mathrm{~km}$

8 The Greenbelt Study Area was larger than the eventual size of the GGH greenbelt and included lands under the jurisdiction of the Greater Toronto Area regions of Durham, York, Halton and Peel; the cities of Toronto and Hamilton; the tender fruit and grape lands as designated in the Region of Niagara's official plan; the Niagara Escarpment Plan and the Oak Ridges Moraine Conservation Plan (MMAH, 2004). 
greenbelt cycling route was launched in the summer of 2015, and visitors can now access downloadable regional maps to plan their trips or follow 900 new directional road signs posted along the route (Wallcraft, July 3, 2015). In addition, this protected landscape provides many other recreational and tourism opportunities to residents within the GGH such as hiking, horse farms, camping, skiing, and golfing along with other seasonal activities such as apple picking and sugar shacks.

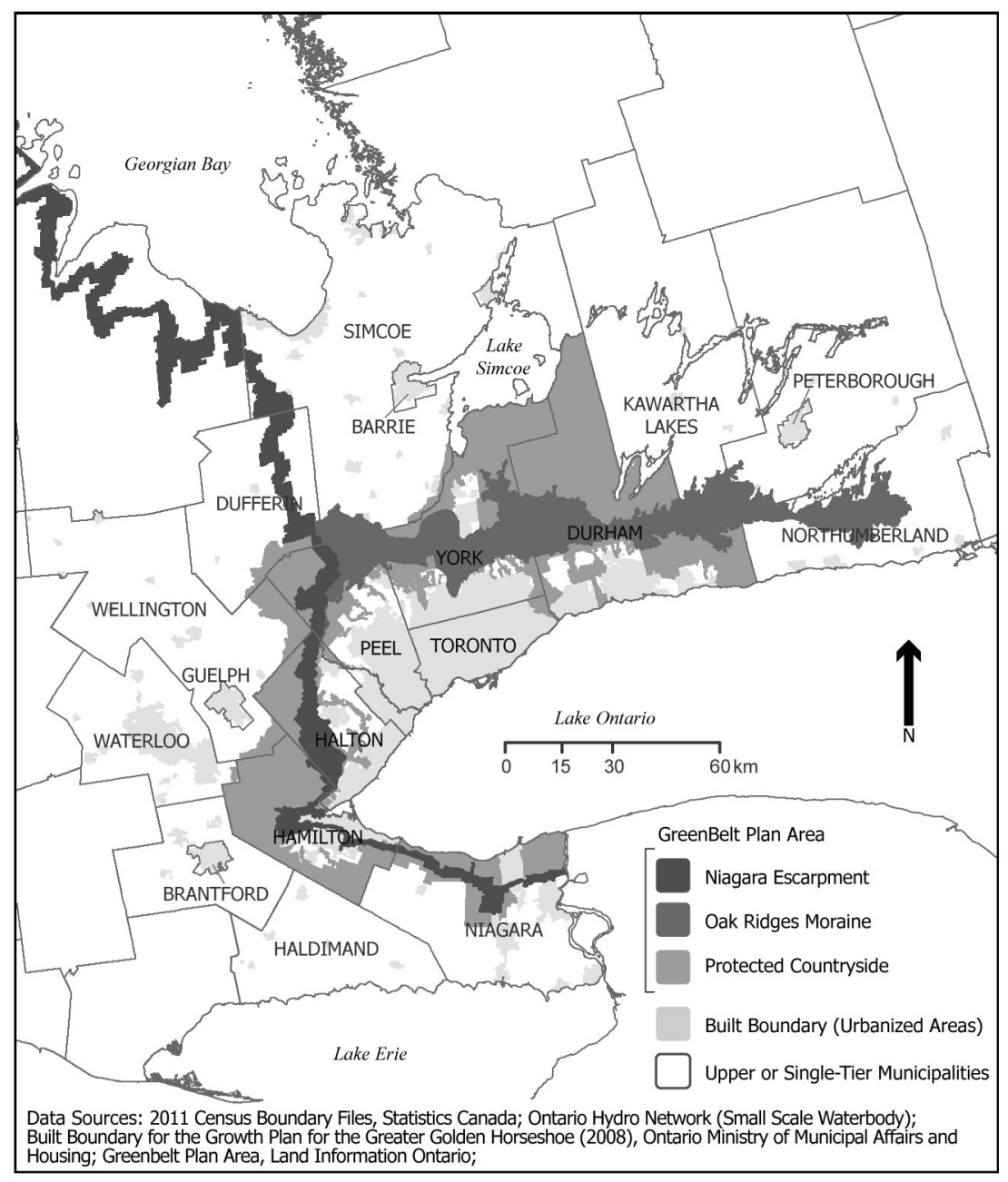

\section{Figure 2.2: The Greater Golden Horseshoe Greenbelt}

Source: Ministry of Infrastructure, 2006; Ministry of Municipal Affairs and Housing, 2005 
Right from the time that the Greenbelt Plan was introduced, there was controversy about its boundaries. The strongest objections about how the greenbelt boundaries were drawn and what land was included or excluded from the plan came from the development industry and the agricultural community. In 2005, a representative from the Ontario Federation of Agriculture called the greenbelt policies "the most draconian piece of legislation farmers in this Province have ever been faced with", as it "ignores science, it ignores economics, it ignores farm businesses and their contributions to the Ontario economy" (Ontario Federation of Agriculture, 2005). Several years have passed since the time the Greenbelt Plan was introduced and those original tensions and scepticism regarding the greenbelt's policies seem to have subsided. Polls conducted in 2013 for the Friends of the Greenbelt Foundation showed that support for the greenbelt was at an all-time high with $93 \%$ of Ontarians supporting this landscape and with $74 \%$ of respondents wanting the greenbelt to continue to grow (Environics Research Group, 2013). While it is unclear if the survey respondents fully understood all facets of the Greenbelt Plan, the general public within Ontario seems to have become more accepting and supportive of the greenbelt policies.

The municipal level of government has been tasked with the primary responsibility for implementing these policies. Municipalities are responsible for designating agricultural lands, identifying key natural heritage features, and incorporating this information into their Official Plans. Municipalities are required to bring their planning documents into conformity with the Greenbelt Plan and make sure that local councils' decisions conform as well. The Ministry of Municipal Affairs and Housing is the provincial ministry responsible for these policies and their staff will conduct a review of the Greenbelt Plan every ten years to assess the plan's effectiveness. The first 10-year review is taking place in 2015. It is only during this review process that the MMAH can make amendments to protected areas within the greenbelt and those changes are not allowed to decrease the total area of the greenbelt (MMAH, 2005). The province has also set up two organisations to help support the Greenbelt Plan: (1) The Friends of the Greenbelt Foundation, one of the biggest champions of the plan, has helped to increase the public's awareness of this protected landscape through their successful grant-making programmes, research activities, highway and trail signage and promotion of farmers markets and tourism; and (2) the Greenbelt Council, a group of experts from both the public and private sectors that provide advice to the Minister about the greenbelt. 


\section{7 "PLACES TO GROW: BRIGHTER CHOICES, BRIGHTER FUTURE"}

To get a complete understanding about Ontario's greenbelt, one must also look at the so-called "Places to Grow" legislation, as these policies were meant to work together with one another. In 2005, the province passed the Places to Grow Act to serve as a foundation for preparing growth plans in Ontario and the first plan released was for the GGH in 2006 (Ministry of Infrastructure, 2005). This 25-year growth plan was designed to manage growth in the region until 2031, create a clearer picture for long-term investment decisions and to secure the economic prosperity of the region (Ministry of Infrastructure, 2006). The principles that will guide the province's decisions on how to develop land and invest funding during the next 30 years include:

- Building compact, vibrant, and complete communities ${ }^{9}$;

- Managing growth to support a strong and competitive economy;

- Protecting valuable natural resources for future generations and;

- Optimising the use of existing and new infrastructure to support compact development (ibid.,10).

Through these principles, the province is advocating an alternative approach to managing population and economic growth based on the ideas of smart growth and sustainability, which emphasize higher density living, infill development, planning mixed-use communities, protecting natural heritage features and supporting alternative transportation systems.

In order to accommodate the millions of new residents expected to come to the region in the coming decades, the province wants the majority of that growth to be handled through intensification in urban areas. The Growth Plan states that by the year 2015, a minimum of $40 \%$ of all residential development occurring annually within each upper and single-tier municipality must be within the built up area (Ministry of Infrastructure, 2006, 14). The majority of this intensification is not to occur within greenfield areas, but rather in a series of 25 proposed urban growth centres located primarily in the downtown areas of the region's mid-sized cities. Urban growth centres are mixed-use communities, which have, or are proposed to have, high to medium density residential developments, good

9 The Growth Plan defines complete communities as meaning "a person's needs for daily living throughout an entire lifetime by providing convenient access to an appropriate mix of jobs, local services, a full range of housing, and community infrastructure including affordable housing, schools, recreation and open spaces for their residents. Convenient access to public transportation and options for safe, non-motorized travel is also provided." (Ministry of Infrastructure, 2006, 41, emphasis is in the original document). 
inter-regional transportation connections and a variety of employment and retail areas to serve residents' needs (Ontario Growth Secretariat, 2005, 1). The provincial government has identified these centres as being suited for additional growth and as such these areas are expected to accommodate a significant portion of population and employment growth, serve as high density employment centres and support transportation infrastructure (Ministry of Infrastructure, 2006, 16). Similar to the Greenbelt Plan, municipalities have to bring their planning documents into conformity with the Growth Plan. The Growth Plan will also be reviewed by the provincial government every ten years with the first review expected to begin in 2015. The reviews of the Niagara Escarpment and Oak Ridges Moraine Conservation Plans were delayed to sync up with the review of the Greenbelt Plan, so the coordinated reviews of all these plans began in 2015. The provincial government under Liberal Kathleen Wynne was elected to a majority mandate for 4 years in 2014, which provides some stability to the coordinated land-use planning review process in 2015. However, while the protection of the greenbelt could be maintained or even strengthened in 2015, its success is highly dependent on what happens with the Growth Plan review. If the province decides to decrease density targets and expand new areas for development, then the Growth Plan's effectiveness could be decreased, which in turn impacts the greenbelt (personal communication, October 28, 2014).

Since the Growth Plan was introduced in 2006, two amendments have either been made or proposed to the original policies. In 2012, the first amendment came into effect for an area that was previously excluded from both the Greenbelt and Growth Plan: Simcoe County. Including the cities of Barrie and Orillia, it was predicted that the "cottage country" area of Southern Ontario could have faced significant growth pressures and leapfrog development over the greenbelt if left without legislative protection over time. So the provincial government made an amendment to the Growth Plan that will allow this area to plan for growth in a way that suits their communities' specific needs, while both curbing urban sprawl and protecting natural areas (Ministry of Infrastructure, January 2012). The Lake Simcoe watershed faces a range of environmental concerns such as excessive nutrient levels in the lake, invasive species, impacts of climate change and new development pressures (Ministry of Environment and Climate Change, 2009). As a result of these concerns and the work of organisations such as Environmental Defense and the Rescue Lake Simcoe Coalition, the provincial government provided additional protection to this environmentally sensitive area in 2008 under the Lake Simcoe Protection Act and Plan. The second amendment to the Growth Plan was proposed in November 2012 and involved updating the population projections upon which the policies were based. The original timeframe from the Growth Plan was until 2031 (which is now less than 20 years away) and there is the expectation that regional growth will continue at a steady pace past this date. Municipalities also rely on the population and employment projections in the plan 
to make decisions about how much land to make available for future urban development, so there was a need for the province to extend the time horizon of the Growth Plan to assist local and regional governments with their planning. As a result, the second proposed amendment to the plan shows that the GGH could grow to 13.5 million people by 2041 (Ministry of Infrastructure, November 2012).

\subsection{THE GREENBELT IS NOT SEPARATE FROM THE CITY}

One of the main themes underlying most of the UPE literature is that the urban and the natural are not seen as separate entities, but rather as intertwined and inseparable from one another (Keil, 2003, 728). This is in direct contrast to historical ideas about the city and nature, where there was a clear opposition between society and the natural world. Tracing the roots of this separation back to the industrial revolution, nature was seen as external to human society (and even sometimes as its antithesis) and this opposition was further strengthened by the clear separation between town and countryside that was occurring at the time in nineteenth-century capitalism (Wachsmuth, 2012).

The history of greenbelts also relates back to these ideas in that the traditional concept of a greenbelt was that these planning tools created firm boundaries to separate urban areas from the countryside. Dating back to the nineteenth century and Ebenezer Howard's plan for a Garden City, greenbelts were designed to create a clear division between urban and agricultural land, to protect the countryside and to protect against urban development in the fringes (Friends of the Greenbelt Foundation, 2010). While long-established greenbelts (such as those in the UK) may have been built on those traditional ideas, the boundaries between city and countryside are much more fluid in more recently created greenbelts (such as the Ontario one). The GGH greenbelt is intricately connected with the urban centres of the $\mathrm{GGH}$ region and this connection occurs on multiple scales including the physical, the metabolic, the conceptual and the legislative.

In 2013, the provincial government passed an amendment to the Greenbelt Plan creating a new "urban river valley" designation, which would allow publicly owned lands within urban river valleys currently outside the greenbelt to be brought into the Plan (MMAH, 2013). By adding this new urban river valley designation to the Greenbelt Plan, it will now be possible for urban municipalities located outside the greenbelt to be physically connected to this greenspace through their river valleys. The urban river valley designation does not allow for privately owned land to be included into the greenbelt and most of these river valleys were already protected by other jurisdictions. The main significance of the urban river valleys 
designation is psychological as urban residents can feel more connected to the greenbelt, as they will not have to drive outside of the city limits to access this space. Through the urban river valleys, residents in cities can have their own "piece of the greenbelt" right in their own backyards, which offers an opportunity for potentially millions of urban residents in the GGH to connect to the greenbelt and gain a new understanding and appreciation of this complex landscape (Ontario Greenbelt Alliance, 2013, 5). Since the amendment was passed in 2013, the Greenbelt Foundation has launched a "Love The Ravines" social media campaign to promote these urban greenspaces, and municipalities such as Oakville and Mississauga have passed motions in their councils asking the province to extend the greenbelt into their river valleys (Ontario Greenbelt Alliance, February 28, 2014). This returns our discussion once again to the notion of urban metabolism. Swyngedouw and Heynen (2003, 906-907) have stated that the

"interwoven knots of social process, material metabolism and spatial form that go into the formation of contemporary urban socionatural landscapes ( ... ) [I]t is on the terrain of the urban that [the] accelerating metabolic transformation of nature becomes most visible, both in its physical form and its socioecological consequences." (emphasis is in the original text).

In the case of the GGH greenbelt, one can see several examples of how this landscape plays an active role in the metabolic relationships between the urban centres within the GGH region and the countryside. The greenbelt was designed to provide a "continuous and permanent land base necessary to support human and ecological health in the Greenbelt and beyond" and the natural heritage systems protected by the plan are "functionally inter-related and collectively support biodiversity and overall ecological integrity" (MMAH, $2005,15)$. The greenbelt policies take a so-called "systems based" approach to planning, whereby decision makers need to consider the impact of development on the landscape as a whole, rather than just an individual piece of land. The greenbelt is home to 78 at risk or endangered species and the primary threat to these species is habitat loss and fragmentation (David Suzuki Foundation, 2011, 15). However, by preserving such a large area, the greenbelt helps to protect against habitat loss and fragmentation from development pressures, protects against biodiversity loss and provides important wildlife corridors for at-risk species such as the Jefferson salamander. The greenbelt also protects many of the headwaters and watersheds that connect to Lake Ontario, which is a major source of drinking water for the GGH region. Source water protection is one of the most effective ways of protecting the drinking water safety and the greenbelt's watersheds help to do that by providing many services such as water filtration, flood control and waste treatment (David Suzuki Foundation, 2008, 4). 
The greenbelt also protects some of the highest quality agricultural land in Canada and farming is the main land use within the greenbelt. Greenbelt farmers have more than 8 million potential customers within half a day's drive of their farms and, as such, the greenbelt provides a tremendous opportunity for the GGH region's urban residents to access locally grown food (Petrie et al., 2008). In recent years, there has been a huge demand within urban areas for farmers' markets, where locally grown and made products are available to urban residents. In 2009, the Greenbelt Farmers' Market Network was established to support farmers across the GGH region to sell their products directly to customers and to increase profits, and there are now more than 100 markets in the network (personal communication, October 14, 2014). There is also a huge demand for foods preferably consumed by the burgeoning immigrant populations in the region's suburban and urban municipalities. The potential market for "world crops" has been estimated at $\$ 720$ million annually in the Greater Toronto Area alone, yet this demand is met almost solely through imports (JRG Consulting, 2014). Despite challenges such as climate, soil conditions and customer preferences, the greenbelt provides a unique opportunity for farmers to meet these demands for world crops locally (ibid.). While a thorough and comprehensive empirical study of the flows of energy, waste and materials in and out of the greenbelt does not yet exist, the above examples highlight the ways in which the GGH greenbelt can strengthen and re-affirm the metabolic relationships within the region.

The Greenbelt and Growth Plans for the GGH Region were both introduced around the same time by the provincial government of Ontario and these plans are meant to be read in conjunction with one another. While two different ministries are responsible for these plans and they are separated into two different pieces of legislation, the Greenbelt and GGH Growth Plans are very much interlinked with one another and their long-term success is dependent on both of them meeting their goals. Because the provinces set up their legislative framework this way for the greenbelt, it shows that the provincial government did not see future urban development and the preservation of agricultural land as separate issues, but rather as interconnected with one another.

\subsection{THE CHANGING RELATIONSHIP BETWEEN GREENBELTS AND CITIES}

While the traditional concept of the greenbelt dates back to the nineteenth century, more recent research is showing that greenbelts in the twenty-first century are facing a host of new challenges and land-use conflicts and, as such, may be doing more than their predecessors were. Greenbelts may become increasingly important in coming years to cities due to changing global conditions such as climate change, water scarcity, escalating 
oil prices and concerns about food security (Friends of the Greenbelt Foundation, 2010). There has been a lot of research recently published about the GGH greenbelt showing the range of environmental benefits it provides. A study by the David Suzuki Foundation has found that these natural areas found within the greenbelt provide significant ecosystem services (such as carbon and water storage, flood control, waste treatment, water filtration and pollination) and that this natural capital can be valued at $\$ 2.6$ billion per year or $\$ 3487$ per hectare (David Suzuki Foundation, 2012). This foundation has also found that the greenbelt could play a significant role in mitigating climate change impacts through its carbon storage, in that the greenbelt's forests and wetlands store 47-million tonnes of carbon and that the economic value of this stored carbon is estimated at $\$ 2.4$ billion (in 2005 dollars) (Tomalty, 2012). Lessons from land conservation exercises in other jurisdictions are also instructive here. A report from the UK suggested that the country's greenbelts have the potential to mitigate some of the negative impacts associated with climate change, specifically in cities, through reducing the urban heat island effect and reducing flood risks around urban areas (The Campaign to Protect Rural England and Natural England, 2010). Also, policy measures such as greenbelts are seen as ways to increase food security for urban areas, in that by protecting locally grown food sources they can reduce the transportation costs and distances of food production, which can in turn help to make cities more self-sufficient in the face of climate change, escalating fuel prices and global population growth (ibid.). As a result of these benefits, greenbelts could become increasingly important for urban and suburban areas in the future, in particular in the face of uncertain global changes. As the role of greenbelts has evolved (and will continue to evolve) over time, this highlights the changing relationship between the city and nature, as cities and urban residents may become more dependent on the greenbelt's assets in the future.

\subsection{CONCLUSION: THE GGH GREENBELT AS BOUNDARY IN THE UNBOUNDED REGION}

In outlining their "manifesto" for UPE, Heynen et al. $(2006,12)$ state that "the urban world is a cyborg world: part natural/part social, part technical/part cultural, but with no clear boundaries, centres or margins". Although the greenbelt has been constructed with the ostensible purpose to be a planning tool creating a firm boundary between the city and the countryside, it has in fact become more of a territorial threshold that helps facilitate, negotiate and hold suburban boundaries ${ }^{10}$. The greenbelt in its current form in Ontario is a messy and complicated construction. As a regulatory instrument it is rolled out, rolled back,

10 We thank one of our reviewers for asking us to clarify these points. 
defended through the modalities of suburban governance, between the state, the market and privatism (Ekers et al., 2012). Being born out of a neoliberal period of policymaking in Ontario, it is brought into play and contested through discourses of value and valorisation of nature. At the same time, the moral and political geography of the greenbelt is potentially complex: whose interests are being served by the greenbelt? Whose interests are served by not having the greenbelt? Who acts upon those interests on whose or what behalf? It is as of yet unclear whether and to what degree such a "greenbelt of the 21st century" can stem the tide of suburbanisation, given all the pressures and demands placed on it. The current 10-year review will yield additional insights into this question.

At this point, we can safely say, though, that rather than being a hard line, the greenbelt instead becomes a multi-faceted space of negotiation through which meaningful, sustainable and long-term relationships between the city and the countryside are being enacted. Instead of the zero-one exclusivity that characterised traditional environmentdevelopment relationships, the greenbelt in its emerging form provides the terrain for a postsuburban relationality of a new kind. It becomes part of a canvas of new metabolic relationships (or if you wish, ecosystem services) in sectors such as mobility, water, food, recreation and even culture. This makes the greenbelt a constitutive piece and even an enabler in the post-suburbanisation of the region as new and aging suburban landscapes evolve into a more appropriate and perhaps resilient rapport with their assumed counterpart in the regional landscape. This forges as of yet underdeveloped societal relationships with nature that connect urban and non-urban activities in novel ways. The conventional "consumption" of land through development is transformed into the "production" of a new social and urban nature where post-suburbanisation processes are enclosed, enabled, and always emerging. Quinby $(2011,128)$ has warned that "the spatiotemporal ecology of the post-metropolis has subsumed the entire built environment of North America, displacing the logic of the traditional city within a suburban-like order of horizontality and dispersal". This has come with a simultaneous "explosion of romantic and ideological writing on cities that does little to uncover the connection between our environments and capitalist power" (ibid., 129). The currently widely practiced wishful thinking of a renewed urbanism in the centre has done little to theorise the wider metabolic relationships that are at the basis of the reproduction of urban life in the inner city, its in-between regions and its outer suburbs.

In this article we suggested to view one important aspect of these relationships, those embedded in the new greenbelt, to closer scrutiny using an UPE perspective. We can now conclude that, understood in the manner suggested above, the greenbelt is not a static enclosure, a timeless emerald band in an otherwise alienated and destructive neoliberal cityscape of horizontalized high density and commercialised space (Quinby, 2011). Much more, it is part and parcel of a performative postsuburban renewal that has the potential 
to point beyond the drab, dichotomous status quo of destructive hypergrowth in the city and green musealisation outside of its conventional borders. Recognising the important regional and global metabolisms that sustain the urban political ecologies of the greenbelt and its surroundings opens the conceptual door to a new way of thinking about postsuburbia as a terrain of liberation. In a recent commentary on the politics of the urban and the wild, of spaces of environmental consumption, recreation and leisure, Daniel Aldana Cohen $(2014,159)$ has concluded: "The shameless, confrontational pursuit of low-carbon leisure, ... and mixing in the most useful expertise around, could produce democratic, decarbonised cities - not cramped, dull warehouses, but diverse, stimulating metropoles with plentiful access to the wild beyond". While Southern Ontario's fledgling greenbelt still has to prove its boundary-setting power, we can already attest it the ability to be a powerful space of redefinition of the Toronto region's postsuburban reality. 


\subsection{REFERENCES}

Amati, M., \& Taylor, L. (2010). From green belts to green infrastructure. Planning Practice \& Research, 25(2), 143-155.

Angelo, H. and Wachsmuth, D. (2014). Urbanizing political ecology: A critique of methodological cityism. In Brenner, N. (Ed.) Implosions/explosions. (pp. 372-385). Berlin, Germany: Jovis.

Barraclough, L. R. (2011). Making the San Fernando valley: Rural landscapes. Urban development and white privilege. Athens, GA: University of Georgia Press.

Brenner, N. (2013). Theses on urbanization. Public Culture, 25(1), 85-114.

Buxton, M. (2011). Greenbelt and peri-urban resilience to fundamental change. Global greenbelts conference, local solutions to global challenges; Closing panel: Five big ideas for greenbelts, March 24, 2011, Toronto, Canada.

Buxton, M., \& Goodman, R. (2002). Maintaining Melbourne's green wedges: Planning policy and the future of Melbourne's green belt. Melbourne, Australia: RMIT University.

The Campaign to Protect Rural England and Natural England. (2010). Green belts: A greener future. Retrieved from http://www.cpre.org.uk/campaigns/planning/green-belts/green-beltscampaign-update

Cohen, D. A. (2014). Seize the Hamptons. Jacobin Magazine, 15/16, (Fall), 151-159.

David Suzuki Foundation. (2008). Ontario's wealth, Canada's future. Appreciating the value of the greenbelt's eco-services. Retrieved from http://www.davidsuzuki.org/publications/ reports/2008/ontarios-wealth-canadas-future-appreciating-the-value-of-the-greenbelts-ecoserv/

David Suzuki Foundation. (2011). Biodiversity in Ontario's greenbelt. Retrieved from http://www. davidsuzuki.org/publications/downloads/2011/REPORT-GB_Habitat-Dec2011.pdf

David Suzuki Foundation. (2012). Carbon in the bank: Ontario's greenbelt and its role mitigating climate change. Retrieved from http://davidsuzuki.org/publications/reports/2012/carbon-inthe-bank-ontarios-greenbelt-and-its-role-in-mitiga ting-climate-change/

Desfor, G. and Keil, R., (2004). Nature and the city: Making urban environmental policy in Toronto and Los Angeles. Tucson, AZ: University of Arizona Press.

Ekers, M., Hamel, P., \& Keil, R. (2012). Governing suburbia: Modalities and mechanisms of suburban governance. Regional Studies, 46(3), 405-422.

Environics Research Group. (2013). Greenbelt foundation awareness measurement fall 2013. Retrieved from http://www. greenbelt.ca/environics 2013

Friends of the Greenbelt Foundation. (2010). Ontario's greenbelt in an international context. Friends of the Greenbelt Foundation. Retrieved from http://www.cielap.org/pdf/ GreenbeltInternationalContext2010.pdf

Friends of the Greenbelt Foundation. (n.d). About the greenbelt. Retrieved from http://www. greenbelt.ca/about_the_greenbelt

Gandy, M. (2004). Rethinking urban metabolism: Water, space and the modern city. City, 8(3), 363379.

Girardet, H. (2008). Cities, people, planet: Urban development and climate change. Chichester: Wiley. Hamel, P. and Keil, R. (Eds.). (2015). Suburban governance: A global view. Toronto, ON: University of Toronto Press.

Harvey, D. (2007). A brief history of neoliberalism. Oxford, England: Oxford University Press. 
Heynen, N. (2006). Green urban political ecologies: Toward a better understanding of inner-city environmental change. Environment and Planning A, 38(3), 499-516.

Heynen, N. (2014). Urban political ecology I: The urban century. Progress in Human Geography, 38(4), 598-604.

Heynen, N., Kaika, M., and Swyngedouw, E. (2006). Urban political ecology: Politicizing the production of urban natures. In N.C. Heynen, M. Kaika, and E. Swyngedouw (Eds.), In the nature of cities: Urban political ecology and the politics of urban metabolism (pp. 1-20). Abingdon: Routledge.

Heynen, N., \& Perkins, H. A. (2005). Scalar dialectics in green: Urban private property and the contradictions of the neoliberalization of nature. Capitalism Nature Socialism, 16(1), 99-113.

Jonas, A. E., Pincetl, S., \& Sullivan, J. (2013). Endangered neoliberal suburbanism? The use of the federal endangered species act as a growth management tool in southern California. Urban Studies, 50(11), 2311-2331.

JRG Consulting Group. (2014). Agriculture by the numbers: Understanding the greenbelt's unique advantages. Friends of the Greenbelt Foundation. Retrieved from http://www.greenbelt.ca/ agriculture_by_the_numbers_2014

Judd, D. R., \& Simpson, D. W. (Eds.). (2011). The city, revisited: Urban theory from Chicago, Los Angeles, and New York. Minneapolis, MN: University of Minnesota Press.

Keil, R. (2003). Urban political ecology 1. Urban Geography, 24(8), 723-738.

Keil, R. (2005). Progress report-urban political ecology. Urban Geography, 26(7), 640-651.

Keil, R., (2011a). Frontiers of urban political ecology. In M. Gandy (Ed.), Urban constellations. (pp. 26-30). Berlin, Germany: Jovis.

Keil, R., (2011b). Transnational urban political ecology: Health, environment and infrastructure in the unbounded city. In G. Bridge and S. Watson (Eds.), The new companion to the city. (2nd ed.) (pp. 713-725). Oxford, England: Wiley-Blackwell.

Keil, R., (Ed.). (2013). Suburban constellations: Governance, land and infrastructure in the 21st century. Berlin, Germany: Jovis.

Keil, R. and Boudreau, J.A. (2006). Metropolitics and metabolics: Rolling out environmentalism in Toronto. In N.C. Heynen, M. Kaika, and E. Swyngedouw (Eds.), In the nature of cities: Urban political ecology and the politics of urban metabolism. (pp. 41-62). Abingdon: Routledge.

Keil, R. and Graham, J. (1998). Reasserting nature: Constructing urban environments after Fordism. In B. Braun and N. Castree (Eds.) Remarking reality: Nature at the millennium. (pp. 98-124). London, England: Routledge.

Keil, R. and Ronneberger, K. (1994). Going up the country: Internationalization and urbanization on Frankfurt's northern fringe. Environment and Planning D: Society and Space, 12(2), April, 137-166.

Keil, R. and Shields, R. (2013). Suburban boundaries: Beyond greenbelts and edges. In R. Keil, (Ed.), Suburban constellations. (pp. 71-78). Berlin, Germany: Jovis.

Keil, R. and Whitehead, M. (2012). Cities and the politics of sustainability. In K. Mossberger, S.E. Clarke, and P. John (Ed.), The Oxford handbook of urban politics. (pp. 520-523). New York, NY: Oxford University Press.

Kennedy, C., Cuddihy, J., \& Engel-Yan, J. (2007). The changing metabolism of cities. Journal of Industrial Ecology, 11(2), 43-59.

Kortelainen, J. (2010). The European green belt: Generating environmental governance-reshaping border areas. Quaestiones Geographicae, 29(4), 27-40.

Krueger, R. and Gibbs, D. (Eds.). (2007). The sustainable development paradox: Urban political economy in the United States and Europe. New York, NY: Guildford Press. 
Lawhon, M., Ernstson, H., \& Silver, J. (2014). Provincializing urban political ecology: Towards a situated UPE through African urbanism. Antipode, 46(2), 497-516.

Loftus, A. (2012). Everyday environmentalism: Creating an urban political ecology. Minneapolis, MN: University of Minnesota Press.

Macdonald, S., \& Keil, R. (2012). The Ontario greenbelt: Shifting the scales of the sustainability fix? The Professional Geographer, 64(1), 125-145.

Marvin, S. and Medd, W. (2006). Metabolism of obe-city: Flows of fat through bodies, cities and sewers. In N.C. Heynen, M. Kaika, and E. Swyngedouw (Eds.), In the nature of cities: Urban political ecology and the politics of urban metabolism. (pp. 143-156). Abingdon: Routledge.

Metrolinx. (2008). The big move. Transforming transportation in the Greater Toronto area and Hamilton. Government of Ontario. Retrieved from http://www.metrolinx.com/thebigmove/ Docs/big_move/TheBigMove_020109.pdf

Ministry of Environment and Climate Change. (2009). Lake Simcoe protection plan. Queen's Printer for Ontario. Retrieved from http://www.ontario.ca/environment-and-energy/lake-simcoeprotection-plan

Ministry of Infrastructure. (2005). Places to grow act, 2005. Toronto: Legislative Assembly of Ontario. Retrieved from http://www.ontla.on.ca/documents/Bills/38_Parliament/Session1/b136rep_e. htm

Ministry of Infrastructure. (2006). Places to grow. Better choices. Brighter future. Growth plan for the Greater Golden Horseshoe 2006. Retrieved from http://www.pir.gov.on.ca/english/growth/ gghdocs/FPLAN-ENG-WEB-ALL.pdf

Ministry of Infrastructure. (January 2012). Proposed amendment 2 to the growth plan for the Greater Golden Horseshoe, 2006. Retrieved from https://www.placestogrow.ca/content/ggh/ amendment2/gghplan-pa2-e.pdf

Ministry of Infrastructure. (November 2012). Simcoe sub-area amendment, January 2012. Retrieved from https:// www.placestogrow.ca/index.php?option = com_content\&task = view\&id $=$ 210\&ltemid $=15 \#$ feedback

Ministry of Infrastructure. (2013). The Greater Golden Horseshoe. Retrieved from https://www. placestogrow.ca/ index.php?option $=$ com_content\&task $=$ view\&id $=270 \& 1$ temid $=84$

Ministry of Municipal Affairs and Housing. (2004). Towards a golden horseshoe greenbelt task force. Discussion paper: A framework for consultation. Toronto: Queen's Printer for Ontario.

Ministry of Municipal Affairs and Housing. (2005). Greenbelt plan, 2005. Toronto: Queen's Printer for Ontario.

Ministry of Municipal Affairs and Housing. (2013). Greenbelt plan amendment \# 1. Retrieved from http://www.mah.gov.on.ca/Page10215. aspx

Monstadt, J. (2009). Conceptualizing the political ecology of urban infrastructures: Insights from technology and urban studies. Environment and Planning A, 41(8), 1924-1942.

Natural Economy Northwest. (2008). The economic value of green infrastructure. Kendal: Natural Economy Northwest.

Ontario Federation of Agriculture. (2005). Comments by: Paul Mistele, Vice-president. Ontario federation of agriculture. Standing committee on general government - bill 135. (January 31, 2015). Queen's Park, Toronto, Ontario. Retrieved from http://www.ontarioagriculture.ca/ uploads/File/Lobby\%20Activities/2005/Janary/Paul\%20Mistele\%20-\%20Comments\%20on\%20 General\%20Government\%20Bill\%20135.pdf 
Ontario Greenbelt Alliance. (2013). Good things are growing in Ontario. Expanding Ontario's greenbelt through urban river valleys. Retrieved from https://environmentaldefence.ca/report/ report-good-things-are-growing-in-ontario/

Ontario Greenbelt Alliance. (2014). Happy 9th birthday to the Ontario greenbelt. Retrieved from http:// greenbeltalliance.ca/blog/happy-9th-birthday-ontarios-greenbelt

Ontario Growth Secretariat. (2005). Urban growth centres in the greater golden horseshoe. Retrieved from http://www.pir.gov.on.ca/userfiles/page_attachments/Library/4/UGC_TechnicalPaper_ Winte05_Feb.pdf?N_ID $=4$

Ontario Liberal Party. (2002). Growing strong communities. The Ontario Liberal plan for clean, safe communities that work.

Petrie, S., et al., (2008). Greenbelt agriculture. A breakdown of agricultural facts and figures in the greenbelt. The Friends of the Greenbelt Foundation. Retrieved from http://greenbelt.ca/sites/ default/fies/research/greenbelt_agriculture_a_breakdown_of_agricultural_facts_and_figures_ in_the_greenbelt.pdf

Phelps, N.A. and Wu, F. (Eds.). (2011). International perspectives on suburbanization: A post-suburban world? London, England: Palgrave Macmillan.

Pincetl, S. (2010). From the sanitary city to the sustainable city: Challenges to institutionalising biogenic (nature's services) infrastructure. Local Environment, 15(1), 43-58.

Pincetl, S., Jonas, A. E., \& Sullivan, J. (2011). Political ecology and habitat conservation for endangered species planning in Southern California: Region, places, and ecological governance. Geoforum, 42(4), 427-438.

Pincetl, S., Chester, M., Circella, G., Fraser, A., Mini, C., Murphy, S., Reyna, J. and Sivaraman, D. (2014). Enabling future sustainability transitions: An urban metabolism approach to Los Angeles. Journal of Industrial Ecology, 18(6),871-882.

Prigge, W. (1991). Übergänge: Auf der schwelleeinerneuen stadtentwicklungspolitik. In T. Koenigs, (Ed.). Vision offener grünräume: GrünGürtel Frankfurt. (pp. 1173-1178). Frankfurt \& New York: Campus Verlag.

Quinby, R. (2011). Time and the suburbs: The politics of built environments and the future of dissent. Winnipeg, MB: Arbeiter Ring.

Robbins, P. (2007). Lawn people: How grasses, weeds and chemicals make us who we are. Philadelphia, PA: Temple University Press.

Shields, R. (2012). Feral suburbs: Cultural topologies of social reproduction, Fort McMurray, Canada. International Journal of Cultural Studies, 15(3), 205-215.

Sieverts, T. (2003). Cities without cities: An interpretation of the zwischenstadt. London, England: Spon Press.

Statistics Canada. (2013). Table 3.3 population, Greater Golden Horseshoe, 1971, 2001 and 2011. Retrieved from: http://www.statcan.gc.ca/pub/16-201-x/2013000/t003-eng.htm

Swyngedouw, E. (1996). The city as a hybrid: on nature, society and cyborg urbanization. Capitalism Nature Socialism, 7(2), 65-80.

Swyngedouw, E. (2005). Governance innovation and the citizen: The Janus face of governancebeyond-the-state. Urban Studies, 42(11), 1991-2006.

Swyngedouw, E. (2006). Metabolic urbanization: The making of cyborg cities. In N.C. Heynen, M. Kaika, and E. Swyngedouw (Eds.). In the nature of cities: Urban political ecology and the politics of urban metabolism. (pp. 21-40). Abingdon: Routledge.

Swyngedouw, E., \& Heynen, N. C. (2003). Urban political ecology, justice and the politics of scale. Antipode, 35(5), 898-918. 
Swyngedouw, E., \& Kaika, M. (2014). Urban political ecology. Great promises, deadlock... and new beginnings? Documents d'anàlisi geogràfica, 60(3), 459-481.

Teaford, J.C. (2011). Suburbia and post-suburbia: a brief history. In N.A. Phelps and F. Wu (Eds.). International perspectives on suburbanization: A post-suburban world? (pp.15-34). London: Palgrave Macmillan.

Thomas, K., \& Littlewood, S. (2010). From green belts to green infrastructure? The evolution of a new concept in the emerging soft governance of spatial strategies. Planning Practice \& Research, 25(2), 203-222.

Thompson, B. (2015). Review green belt rules to ease London housing crisis, says study. Financial Times, February 24. Retrieved from: http://www.ft.com/intl/cms/s/0/c5fc3608-bb49-11e4-a31f 00144feab7de.html\#axzz3oYljzNaF

Tomalty, R. (2012). Carbon in the bank: Ontario's greenbelt and its role in mitigating climate change. The David Suzuki Foundation. Retrieved from http://greenbelt.ca/sites/default/files/dsf_ ontario_carbon_greenbelt.pdf

Wachsmuth, D. (2012). Three ecologies: Urban metabolism and the society-nature opposition. The Sociological Quarterly, 53(4), 506-523.

Wallcraft, S. (July 3, 2015). Greenbelt route a path to discovering Ontario. The Toronto Star. Retrieved from http://www.thestar.com/autos/2015/07/03/greenbelt-route-a-path-to-discoveringontario.html

Watanabe, T., Amati, M., Endo, K., Yokohari, M. (2008). The abandonment of Tokyo's green belt and the search for a new discourse of preservation in Tokyo's suburbs. In M. Amati (Ed.) Urban greenbelts in the twenty-first century. (pp. 21-36). London, England: Ashgate. 



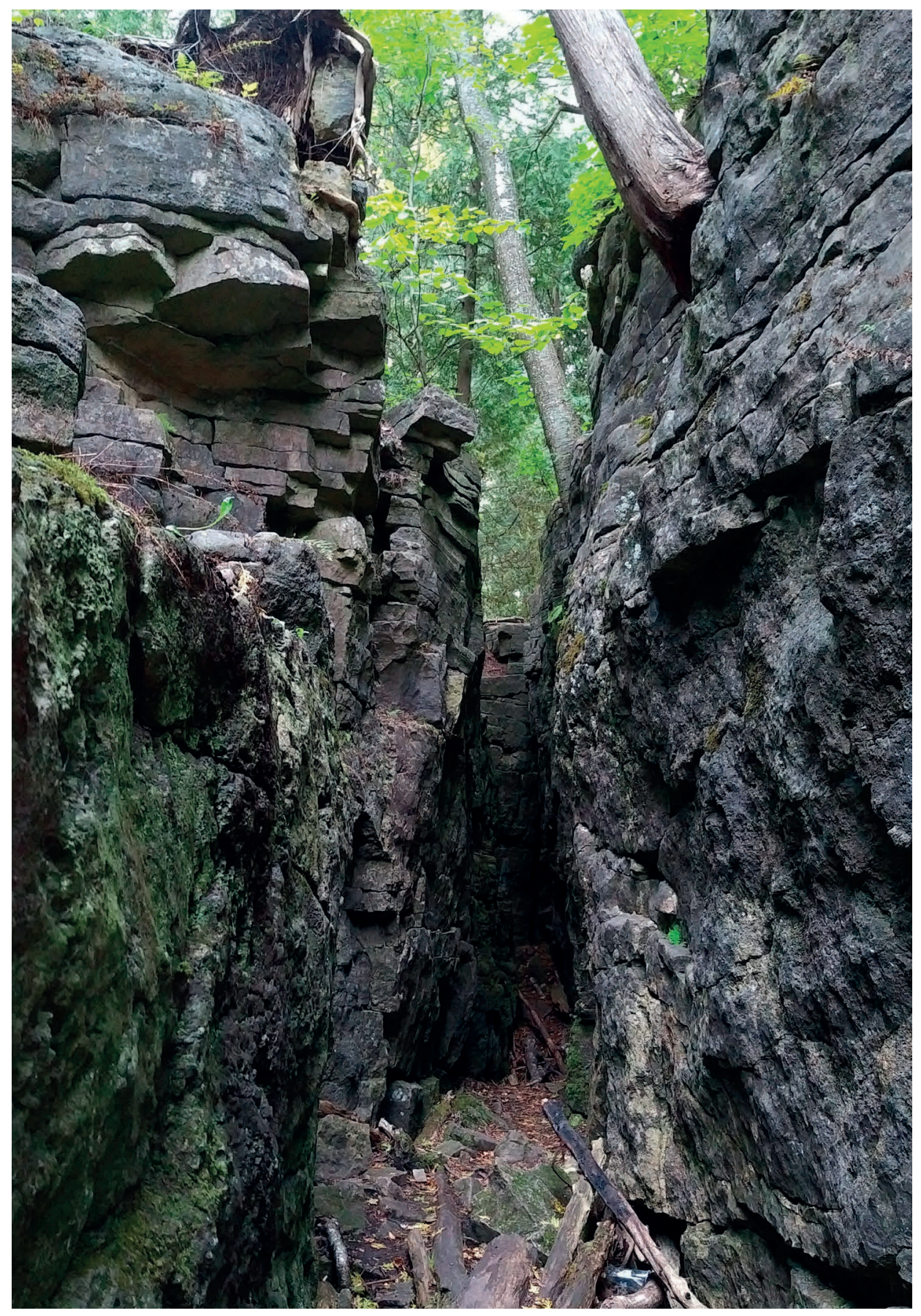

Niagara Escarpment, Limehouse Conservation Area, Town of Halton Hills (2018).

Source: Michael Collens 


\section{The Ontario greenbelt:}

\section{Shifting the scales of the}

sustainability fix?

Published as Macdonald, S., \& Keil, R. (2012). The Ontario greenbelt: shifting the scales of the sustainability fix? The Professional Geographer, 64(1), 125-145. Doi: 10.1080/00330124.2011.586874 


\section{ABSTRACT}

The government of Ontario, Canada, has passed legislation to protect large parts of the southern portions of the province from most development. An extensive Greenbelt Plan was introduced that surrounds the Greater Toronto Area and other regional growth centres. This paper looks at the new policy as a spatial strategy that shifts the scales of environmental and growth management policy in Ontario. The legislation also sets the framework for a state spatial project, i.e. a set of changes in how the regional state internally operates. The current Greenbelt legislation is a new step in a longer-term development by which governments in Ontario have attempted to regulate the relationships between cities and regions, town, and hinterland. Overlapping strongly with what is usually called the Toronto bioregion between Niagara Escarpment, Oak Ridges Moraine and Lake Ontario, the Greenbelt reorganizes space in Southern Ontario in ways that would further ecosystem policies and practices in the area. Theoretically guided by newer debates on re-scaling and regionalism, and based on close reading of the planning and policy documents on the Greenbelt as well as a series of expert interviews, we argue that the current Greenbelt legislation is an act of up-scaling traditional urban-regional regulation in Southern Ontario, which we shall call "extended metropolitanization". Such rescaling recasts traditional political conflicts in new terms. We conclude that "extended metropolitanization" in Southern Ontario has been a process, which has brought nature, the state, and governance together into a new regional sustainability fix.

\section{Keywords}

greenbelt, sustainability fix, regionalism 


\subsection{INTRODUCTION}

The province of Ontario in central Canada is currently the stage for a comprehensive land regulation initiative, which designates half of the province's southern part for intensified development, while the other half will be protected by sweeping greenbelt legislation. During the 2003 provincial election campaign, the Liberal Party, led by Dalton McGuinty pledged to create a greenbelt in the Greater Golden Horseshoe (GGH) region. Right after their election victory in December of that year, the Liberal government introduced Bill 21, the Greenbelt Protection Act, which placed an immediate one-year moratorium on development within a proposed greenbelt study area ${ }^{11}$. During the moratorium, the Ministry of Municipal Affairs and Housing (MMAH) appointed a 13-member Greenbelt task force and after public consultations, they made recommendations to the Minister on how planning the greenbelt should be approached. In February 2005, the Greenbelt Act was passed, and this legislation allowed for the creation of a Greenbelt Plan, which was also released that year. The greenbelt is a permanently protected countryside that stretches from the Niagara Peninsula at the American border to Northumberland County north of Lake Ontario (Figure 3.1). Spanning approximately 1.2 million hectares, the greenbelt contains areas already preserved under the Niagara Escarpment Plan and the Oak Ridges Moraine Conservation Plan. The greenbelt was designed to protect against the loss of agricultural land, natural heritage systems, and water resource systems and to support the economic and social activities associated with rural communities (MMAH, 2005a). The plan generally prohibits the designation of protected areas for development purposes, prevents development close to environmentally sensitive areas and promotes the creation of recreational spaces. The greenbelt includes the following land uses: a) an agricultural system, b) a natural system, c) parkland, open space and trails, and d) settlement areas. Each of these designations offers varying degrees of protection.

In this paper, we view the current Greenbelt Act as a regional state spatial strategy (Brenner, 2004) aimed at reordering the economic and political space of the larger Toronto region. The legislation also sets the framework for a state spatial project, i.e. a set of changes in how the regional state internally operates. Metropolitan regions have recently been the object of state rescaling as nation states and regional governments have repositioned their territories and institutions vis-à-vis other competing jurisdictions and economies. The metropolitan region gains a particularly important role in this game,

11 The Greenbelt Study Area was larger than the eventual size of the Greenbelt and included lands under the jurisdiction of the Greater Toronto Area regions of Durham, York, Halton and Peel; the cities of Toronto and Hamilton; the tender fruit and grape lands as designated in the Region of Niagara's official plan; the Niagara Escarpment Plan and the Oak Ridges Moraine Conservation Plan (MMAH, 2004). 
especially those regions that are viewed as major players in the international competition of global city regions (Boudreau et. al., 2006, 2007). Traditionally, the Toronto Region at the centre of Southern Ontario is a politically weakly constructed and economically defined area, which includes the City of Toronto as well as the urbanizing regions of Halton, Peel, York, and Durham. In the past, this area was commonly referred to as the Greater Toronto Area (GTA). This region is not politically integrated, and after amalgamation of the core metropolitan area in 1998, no further consolidation through territorial or functional measures has occurred. Only sectoral integration has begun to happen, most visibly in transportation with the creation of the regional planning agency Metrolinx (Keil and Young, 2008). Overlapping strongly with what is usually called the Toronto bioregion between Niagara Escarpment, Oak Ridges Moraine and Lake Ontario, the greenbelt may significantly contribute to further ecosystem policies and practices in the area.

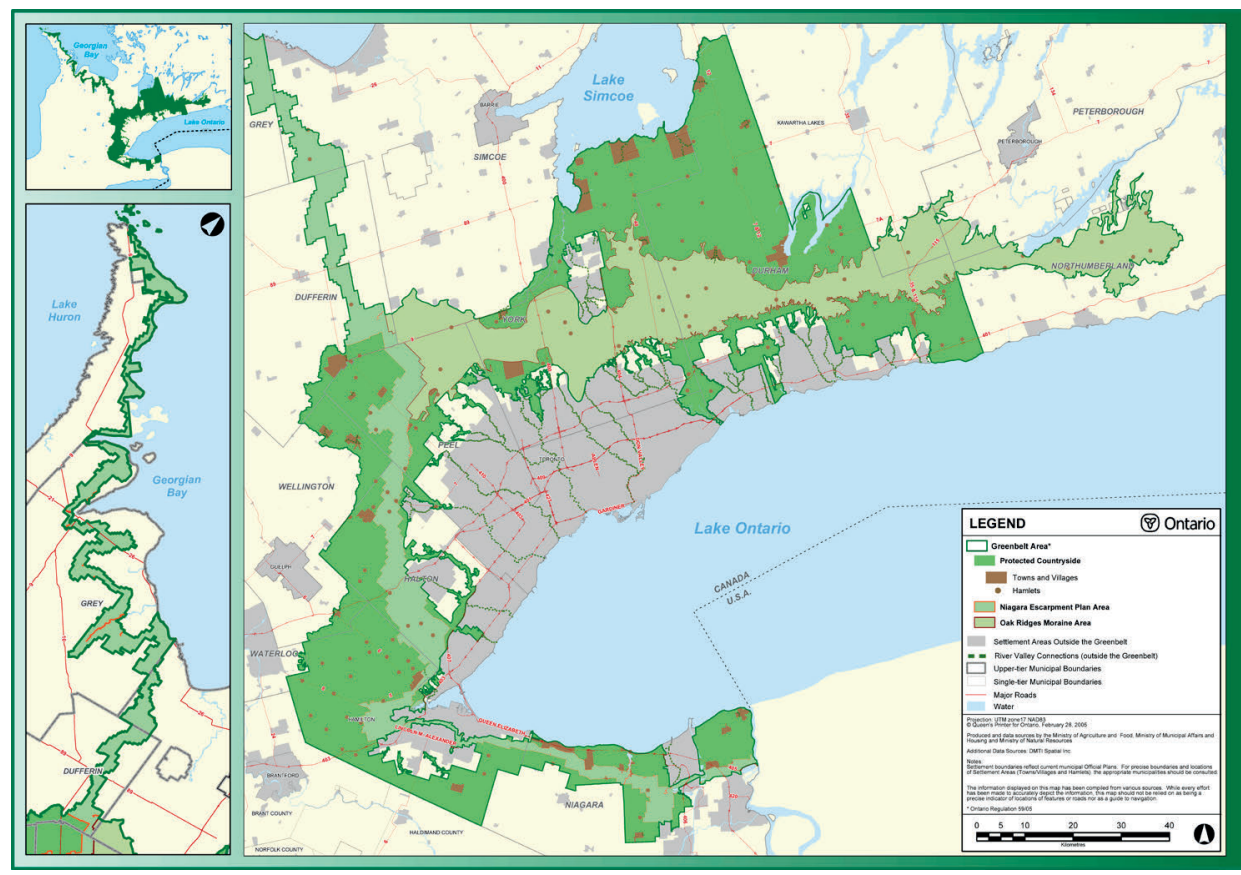

\section{Figure 3.1: The Greater Golden Horseshoe Greenbelt}

Source: Ministry of Municipal Affairs and Housing, 2005

The current greenbelt legislation is a new step in a longer-term development by which governments in Ontario have attempted to regulate the relationships between cities and regions, town, and hinterland. This history included previous greenbelt schemes, 
growth management plans, remedial action plans, regional governance reforms, and conservation legislation of all kinds. Returning only to the 1980s, reveals a strong and continuous tradition of rethinking urban growth in the context of its more or less natural hinterland. Three government policies that set the stage for today's greenbelt discussion stand out. The most important institution created at the time was the Royal Commission on the Toronto Waterfront, an organization put in charge of rethinking land use, conservation, and development along the Lake Ontario waterfront. Under the Chair of David Crombie, a former mayor of Toronto and federal Conservative minister, the Royal Commission declared watersheds part of the waterfront and using an ecosystem approach to planning changed the way Torontonians have been thinking about the nature of their urban region (Crombie, 1992). Second, the Commission on Planning and Development Reform in Ontario chaired by another former Toronto mayor, John Sewell, recommended in 1993 to fundamentally alter the way in which urban growth was regulated and managed and the way in which non-urban areas in Ontario would be seen: not open for any development but receptive to what we would now call "smart development". Lastly, there was the comprehensive proposal by the so-called Golden Commission in 1996 to redesign the local government boundaries of Southern Ontario into a regional city. During the second half of the 1990s, an aggressively neoliberal Ontario government under Mike Harris rescinded the tender beginnings that had been achieved in urban and regional regulation towards more ecological sustainability and redistributive social justice, which were inscribed in all three schemes. Instead, it amalgamated the inner-city municipalities with Metropolitan Toronto and created a rift between the 416 and 905 telephone areas ${ }^{12}$. Instead of restricting development legislatively, the Harris government opened up huge areas of land for the building of single-family home subdivisions, serviced by new roads and other infrastructures. Only late into the tenure of the Tory government, under the pressure of their own electoral basis in the exurban "blubber belt" of the region, the Conservatives made an attempt to find some statutory protection for the Oak Ridges Moraine. These policies and the preexisting Niagara Escarpment Plan were the immediate pieces of preservation legislation that preceded the current Greenbelt Plan. At first glance, the Ontario greenbelt replicates the split of the 416 and 905 areas that had been so disruptive and destructive to regional governance since at least the Mike Harris years. Yet, it is quite a different tool: rather than deepening the split, it actually has the potential to reconcile some of the erstwhile territorial contradictions of Southern Ontario.

12 The 416 telephone area code is used to describe the area within the City of Toronto, while the 905 code refers to suburban areas outside Toronto (including the Niagara Peninsula, Hamilton and Oshawa). In politics, the 416 area traditionally has strong ties to the Liberal and New Democratic Party, while the 905 area has been a Progressive Conservative stronghold. 
This research began as major changes were being made to the Ontario land-use planning system in the early 2000s and has followed those developments throughout the past several years. An extensive number of provincial planning documents were reviewed for this research, along with the critiques and commentaries about these policies in the popular media. To understand the key voices and debates in this process, we focused on several actors in addition to the provincial government such as farming organizations, the development industry, environmentalists, and the affected municipalities. These actors submitted both oral and written comments to the provincial government about these regional policies as they were being developed, and these submissions were reviewed, along documents reflecting how their reactions to the Greenbelt and Growth Plans have evolved over time. Several interviews were conducted in 2006 with representatives from the Ministry of Municipal Affairs and Housing, the Ministry of Energy and Infrastructure, the Friends of the Greenbelt Foundation, the Greenbelt Council, and lobby organizations from the agricultural, environmental and development sectors. The research was embedded in a larger conceptual and methodological concern with the emergence of new regional agency in the Toronto region (for an elaboration of this approach see Boudreau et al., 2006; 2007; Keil and Young, 2008).

In this paper, we argue that the current Greenbelt legislation is in the first instance an act of up-scaling of traditional urban-regional regulation in Southern Ontario, which we shall call extended metropolitanization. The province takes back and fully occupies the space of regional planning. The up-scaling through Greenbelt and Places to Grow legislation outflanks the traditional lines of conflict between inner and outer cities in the province. Secondly, we will present the Greenbelt legislation as a new regional "sustainability fix" (While et. al, 2004). While Toronto remains the leading centre in the region, a policy to regulate land use and transportation now takes into account the fragmented regional "in-between" landscape where much of the regional growth dynamics now plays out (Keil and Young, 2010; Sieverts, 2003). Decision-making actors as well as contesting voices, elite organizations and citizen groups, transportation planners and environmentalists in Toronto have regrouped around a still emerging regional project that is ostensibly set up to achieve success both in the area of economic competitiveness in a globalized world and social cohesion through metropolitan integration in spite of a more dramatically polarized and splintered urban region. The dialectics of Growth Plan and greenbelt is expressive of this spatial logic. 


\subsection{PLACING THE GREENBELT THEORETICALLY: RESCALING, NEW REGIONALISM AND THE "SUSTAINABILITY FIX"}

The new Ontario Greenbelt has been interpreted as part of the provincial government's attempt to create a naturalized growth discourse for the region. Wekerle et al. (2007) argued that by linking growth management and environmental conservation in both the Greenbelt and Growth Plans, the provincial government has used nature as a cornerstone to centralize regional planning within the GGH and that this process could eventually operate in ways that are harmful to the natural environment (see also Wekerle et al., 2009). The greenbelt has also been examined in the context of environmental planning by Fung and Conway (2007), who has analysed the Greenbelt Plan's potential for success and its ability to address past mistakes by comparing this legislation to the earlier policies protecting the Oak Ridges Moraine. Finally, Ali (2008) assessed the Ontario greenbelt initiative by examining factors identified in previous studies as being important to the successful applications of greenbelt policies and concluded that the Ontario example's major strengths include a strong political will and enabling legislation that ensures and enforces the implementation of the Greenbelt Plan. By contrast, the current paper will demonstrate the greenbelt's important function as an instrument of regional governance despite regional fragmentation. We are interested in how the newer literature on metropolitan regions - often summarily referred to as new regionalism - relates to the environment conceptually. We take this discussion further in a more in-depth look at how the greenbelt in intention and effect rescales regional political ecologies. We are unable, in the constraints of this paper, to discuss recent debates on scale here in detail. We take as a starting point the advice of Mahon and Keil (2009, 14; see also Keil and Mahon 2009 for an overview of the debate) who have argued that "Scale theory seems to offer a [...] nuanced approach, one focused on the construction, destruction, and reconstitution of scales and inter-scalar arrangements". While we recognize that the literature on scale offers only one possible lexicon that allows us to talk about scale (others might be topologies, networks, etc.), we prioritize the scale approach here over others as it seems able to explain the mutability of government policy arenas, the dialectical causalities across scales, multiple hierarchies in regional urban political ecologies, changes in existing rule regimes, and the relationships of state and social scales in light of democratic and justice claims (Mahon and Keil, 2009, 17-18). The metropolitan amalgamation of Toronto in 1998 was both a protective boundary-drawing ostensibly benefiting the surrounding exurban region (the power base of the politicians who brought in consolidation and were untouched by any amalgamation itself) and an internal consolidation of economic interests at the metropolitan level. Due to the provincial origin of local government restructuring in Canada, regional problems remain on the agenda of any Ontario government. Whereas the recent round 
of amalgamation did little by way of regional unification (it rather amplified intraregional competition and strife), the unresolved issues of economic, transportation, political and ecological regionalisation remain in everyone's view. These regional issues, be they waste, water, transit, or anything else environmental, have a habit of jumping scales back and forth by spilling both into municipal domains and into provincial or federal jurisdictional powers. What may be 'regional' in scale and responsibility elsewhere is often 'metropolitan' at first glance in Toronto. In order to understand Toronto properly, we therefore need to consider a new metropolitanism, which has found the interest of scholars on both sides of the Atlantic (see Collin and Robertson, 2007; Heinelt and Kübler, 2005). It is the hallmark of this new metropolitanism that it does not allow itself to view consolidation and fragmentation, centralization and decentralization as necessarily oppositional and fixed but as moments in a rescaling process that is using temporary spatio-political fixes. Metropolitan areas are now meant to thrive on diversity rather than uniformity. ${ }^{13}$ In this context, we view the Ontario Greenbelt legislation as part of an extended metropolitanization at once extending to urban governance to a larger scale and submits the urban core to the diffusion and dissemination of the polycentric region.

\subsection{A NEW REGIONALISM?}

The rescaling of regional policy in Southern Ontario does not just extend to the usual institutions of regionalism as commonly referred to in the literature on new regionalism. It also extends specifically and perhaps exceptionally to areas of environmental regulation. The most elaborate work on the new regionalism and its environmental aspects has been done in the UK by David Gibbs, Andrew Jonas and Aidan While (Gibbs, 2006; Gibbs and Jonas, 2000; Jonas et al., 2004a and 2004b; Jonas and Gibbs, 2003; While et al., 2004). The UK research group has unearthed a rich connection between the regionalisation of the state and the regionalisation of environmental policy. Aware of the debates around re-scaling and taking up an important observation by Marshall, they note the importance of the regional level of governance because of its connections in both the ecosystem and socioeconomic sense. Specifically the metabolic-societal relationships with nature in the "supplies of water, land, soil and other natural or semi-natural resources (like wind, sun or different forms of waste sinks)" are relevant in this connection (quoted in Gibbs and Jonas, 2001, 12). Further building on Marshall's idea of "environmentally intelligent regional governance", Gibbs and Jonas discussed the difficulties of relating ecological to

13 There is a terminological imprecision here with regards to the use of the term 'metropolitan/ métropolitain' in English and French. See Boudreau et al., 2006, 2007 for a discussion of this terminology in various literatures. 
political boundaries and concluded: "The environment needs to be a key component of the economic development strategy for a region, rather than marginal to it" $(2001,281)$. They further developed this thinking in introducing the notion of an "'urban sustainability fix' to describe the selective incorporation of ecological objectives in local territorial structures during an era of ecological modernization" (While, Jonas and Gibbs, 2004, 549). In our analysis of the Ontario Greenbelt, we take up this concept of "sustainability fix" and apply it at the regional scale: The extended metropolitanization that the greenbelt represents also entails an extended sustainability fix.

Gibbs' and his co-authors - in their work on the sustainability fix - concern themselves centrally with, and discusses in this context, the shift from urban and regional government to governance, which has brought into sharper relief the non-state actors in environmental governance (Desfor and Keil, 2004; Gibbs and Jonas 2000). The role of environments in a general reordering of regional political spaces has also been noted by scholars who have looked at the "nature of the state" (Whitehead, 2008; Whitehead et al., 2007, 2006). While the challenge of urban and regional sustainability is ultimately a political one, the ways in which we regulate and govern ourselves, and the urban/regional-nature relationships that sustain our cities, are hotly contested. Urban and regional political ecology is not an afterthought of how globalized networks and territories in space are governed but it is central to how the way the spatialization of urban regions now operates. This becomes part of the way in which regions are reimagined in terms of identity (Paasi, 2003).

Next, we are going to give a sketch of the Greater Golden Horseshoe region and provide an overview of the existing Greenbelt legislation in relationship to the overall land-use regulation in Ontario. We will then draw some of the main lines along which the greenbelt proposes to change the way we live in the Golden Horseshoe. Finally, we will discuss the politics of the greenbelt and the context of its implementation.

\subsection{THE GREATER GOLDEN HORSESHOE REGION AND THE IMPACT OF "BUSINESS AS USUAL" DEVELOPMENT}

Population and economic growth within Ontario are concentrated in the so-called Greater Golden Horseshoe region (Figure 3.2). This region was home to 8.1 million people as of 2008 and is bounded by Kitchener-Waterloo to the east, Peterborough to the west, Barrie to the north and Lake Ontario to the south (Hemson Consulting, 2005). The GGH saw the largest growth in employment in the province between 1996 and 2001 and during that 
same time, more than 90 percent of Ontario's population growth occurred here (Winfield, 2005). This region is expected to grow significantly in the coming years as it is predicted that by 2031, the Greater Golden Horseshoe could be home to more than 11.5 million people (Hemson, 2005).

For the past several decades, low-density, automobile-dependent communities built on greenfields at the urban fringe have characterized development within the GGH. If this sprawling development pattern was allowed to continue for the next 30 years and the region's population increased as is predicted, then there is the potential for significant negative environmental, social, and economic impacts to occur. Over the next 30 years, an estimated 1070 square kilometres of land within the region would be urbanized and, 92 percent of the land that would need to be developed to meet the demands of the projected incoming residents will be either Class 1, 2 or 3 agricultural land as classified by the Canadian Land Inventory (IBI Group, 2002). In addition to the loss of agricultural land, the rising population in the coming years could strain the region's transportation systems. There would be a significant increase in vehicle travel within the region over the next 30 years and the majority of this growth would be seen outside of the City of Toronto in its surrounding municipalities. Automobile trips would be expected to increase by 51 percent and as a result, there would be a substantial increase in traffic congestion and emissions of transportation related greenhouse gases would increase by 42 percent over current levels (IBI Group, 2002). This increase in emission levels could contribute to a number of problems as a poor urban air quality, negative health impacts for residents (in particular for children and the elderly) and global climate change. In order to keep up with demand over the next 30 years, $\$ 44$ billion would have to be invested by the public sector into transportation infrastructure and of those investments, 57 percent of that would have to be spent on roads and highways (IBI Group, 2002). As this above analysis highlights, the costs of continuing this "business-as-usual" development pattern that has characterized the region for years would not be sustainable; therefore an alternate approach to urban growth and development within the region will be needed.

Since the mid-1990s, several significant changes have occurred to the provincial landuse planning system within Ontario. During their term from 1995 to 2003, a number of the Conservative government's policies continued to promote and facilitate low density, automobile dependent development within the province. In 1996, the Provincial Policy Statement (PPS) was rewritten and previous policies aimed at curbing urban sprawl, protecting agricultural areas, and promoting public transportation were removed (Winfield, 2005). The Planning Act was amended so that planning decisions would only need to "have regard to" provincial policies and the weakening of this language gave municipalities and developers freer rein in land-use matters (Winfield, 2003). Changes 
were made to the Planning Act that allowed for the speeding up of the development approval process. Municipalities were given less time to process applications and as such, when they could not do so in the allotted timeframes, applicants could appeal directly to the Ontario Municipal Board (OMB), bypassing the local level almost completely. However, in 2001, the Conservatives took some positive steps by launching a series high profile Smart Growth panels throughout Ontario and adopted the Oak Ridges Moraine Conservation Act and Plan.

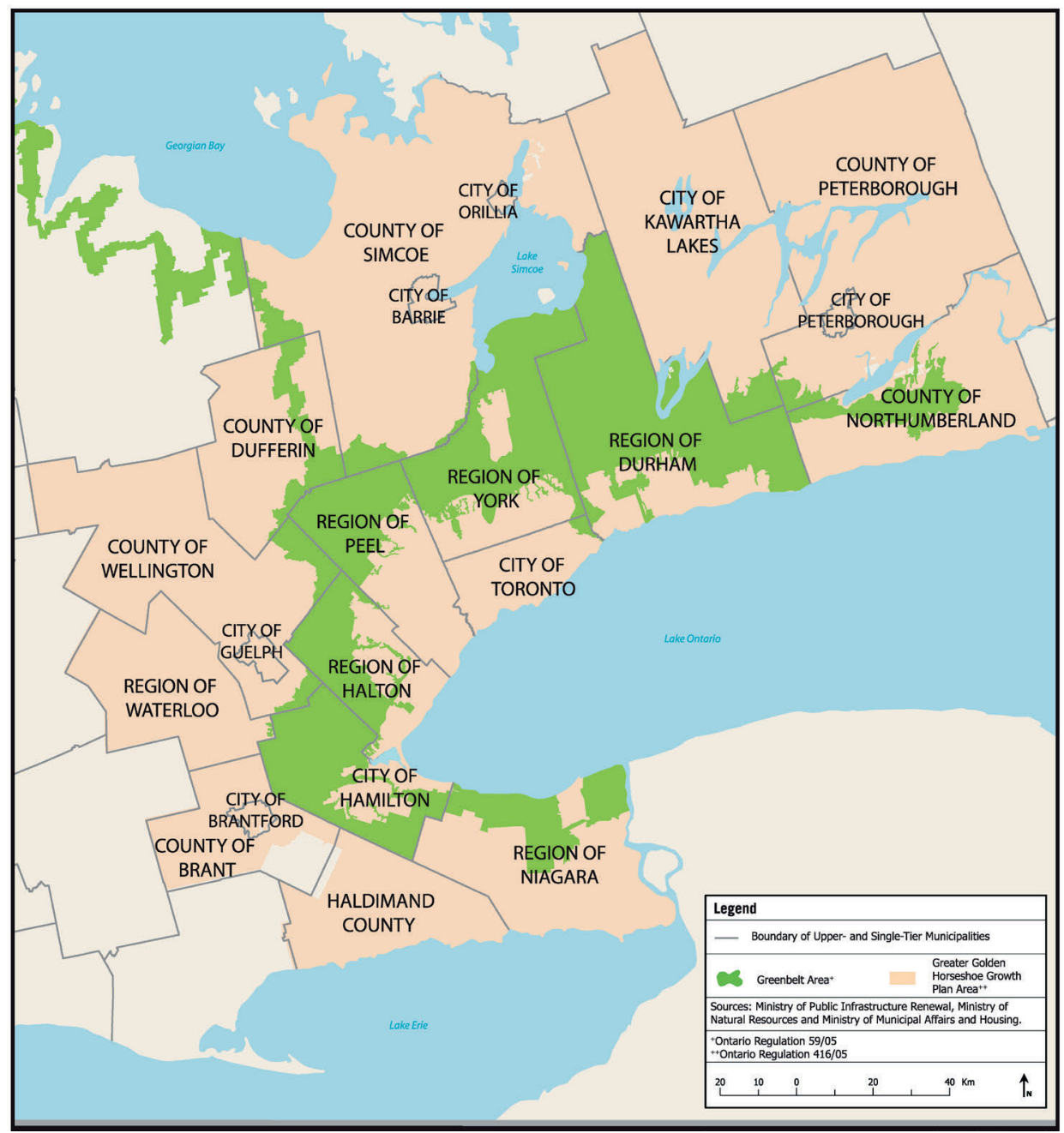

Figure 3.2: The Greater Golden Horseshoe Region

Source: Ministry of Public Infrastructure and Renewal, 2006 
Since the 2003 election of the Liberal government, the province has made a number of changes designed to address the policy vacuum related to regional growth and development in Ontario. In 2003, the Liberals created the Ministry of Public Infrastructure and Renewal (MPIR) by combining the former Ontario Growth Secretariat with the SuperBuild Corporation and this ministry's original mandate was to integrate land-use and infrastructure planning; however that ministry's functions since being incorporated into the new Ministry of Energy and Infrastructure. In 2004, the Strong Communities (Planning Amendment) Act was introduced to allow for more accountability, transparency and public input in the planning process and this legislation restored the 'shall be consistent with provincial policy' language removed by the previous provincial government (MMAH, 2006). A new PPS became effective in 2005 and this document contained important modifications from the 1996 version including an emphasis on intensification, limiting settlement boundary expansions, and protecting renewable resources, wetlands, and specialty cropland (MMAH, 2005c). The Planning and Conservation Land Statute Law Amendment Act was passed in 2006 and was designed to give local councils and the public more say in how their communities develop (MMAH, 2005b). Also, that year, the Greater Toronto Transportation Authority (now called Metrolinx) was created and given the mandate to develop and implement an integrated multi-modal transportation plan for the Greater Golden Horseshoe region. Most salient to this discussion is the introduction of two additional sets of policies that propose to re-define how people would live within southern Ontario in the next 30 years and it is the Greenbelt Act and the Places to Grow Act that will be the focus of the next section of the paper.

\subsection{THE GREENBELT}

The primary responsibility for implementing the Greenbelt Plan falls to the affected municipalities. This level of government is responsible for designating agricultural lands, identifying key natural heritage features within their jurisdictions, and then incorporating this information into their official plans. Municipalities are required to bring their planning documents such as their official plans into conformity with the Greenbelt Plan. Planners and local councils must ensure that their decisions on planning applications conform to the Greenbelt Plan as well. In addition to these municipal responsibilities, the provincial government is still active in the implementation of the Greenbelt Plan. This plan is to be reviewed every ten years to assess the effectiveness of its policies and to update or add any applicable new information. The first 10-year review is to take place in 2015 and it is only during this ten-year review process that the Minister of Municipal Affairs and Housing can make amendments to protected areas within the greenbelt; those changes are not allowed 
to decrease the total area of the greenbelt (MMAH, 2005a). Additionally, the province set up two organizations designed to assist with the successful implementation of the plan. The Greenbelt Council was created in 2005 to provide advice to the Minister on the ongoing implementation of the plan and to assist with the ten-year review process. Started in 2005, the Friends of the Greenbelt Foundation (referred to herein as the Greenbelt Foundation) were given $\$ 25$ million from the provincial government to support and promote activities related to the greenbelt.

\section{6 "PLACES TO GROW: BRIGHTER CHOICES, BRIGHTER FUTURE"}

The greenbelt must be understood in the context of other regional policies. Therefore in 2005, the province passed the Places to Grow Act to serve as a foundation for preparing growth plans in Ontario and the first plan released was for the GGH region (MPIR, 2005). After producing a discussion paper in 2004, two drafts of the plan in 2005 and conducting public consultations, the Ministry of Public Infrastructure and Renewal released the finalized version of the Growth Plan for the Greater Golden Horseshoe in 2006. The plan was designed to manage growth in the region until 2031, create a clearer picture for longterm investment decisions and to secure the economic prosperity of the region (MPIR, 2006). The principles that will guide the provincial government's decisions on how to develop land and invest funding during the next 30 years include:

- Building compact, vibrant, and complete communities ${ }^{14}$;

. Managing growth to support a strong and competitive economy;

- Protecting valuable natural resources for future generations and;

- Optimizing the use of existing and new infrastructure to support compact development (MPIR, 2006).

Through these principles, the provincial government is advocating an alternative approach to managing population and economic growth based on the ideas of smart growth and sustainability, which emphasize higher density living, infill development, planning mixed-use communities, protecting natural heritage features and supporting alternative transportation systems.

14 The Growth Plan defines complete communities as meeting "a person's needs for daily living throughout an entire lifetime by providing convenient access to an appropriate mix of jobs, local services, a full range of housing, and community infrastructure including affordable housing, schools, recreation and open spaces for their residents. Convenient access to public transportation and options for safe, non-motorized travel is also provided." (MPIR, 2006). 
To accommodate the 3.7 million residents expected to come to the region by 2031 , the provincial government wants the majority of that growth to be handled through intensification in urban areas. The Growth Plan states that by the year 2015, a minimum of 40 percent of all residential development occurring annually within each upper and single-tier municipality must be within the built-up area (MPIR, 2006). The majority of this intensification is not to occur within greenfield areas, but rather in a series of twenty-five proposed urban growth centres that located primarily in the downtown areas of the region's mid-sized cities (Figure 3.3). Urban growth centres are mixed-use communities, which have, or are proposed to have, high to medium density residential developments, good inter-regional transportation connections and a variety of employment and retail areas to serve residents' needs (Ontario Growth Secretariat, 2005). The province has identified these centres as being suited for additional growth, and as such these areas are expected to accommodate a significant portion of population and employment growth, serve a high density employment centres and support transportation infrastructure (MPIR, 2006). Similar to the Greenbelt Plan, municipalities have to bring their planning documents into conformity with the Growth Plan. The Growth Plan will also to be reviewed by the province every ten years. Therefore, the Greenbelt and Growth Plans function as "Ying and Yang" (i.e. that is the greenbelt is about where growth is not allowed, while Places to Grow is about where growth is desirable and how this growth should happen) and these policies provide the basis of the province's 'smart growth' agenda for the GGH, according to a director with MPIR (personal communication, February 23, 2005).

Because the Greenbelt and Growth Plans have now been in place for a few years, it is now possible to begin assessing the impacts of these policies. The region has struggled in the past to adequately address governance issues such as unchecked urban sprawl, transportation congestion, and environmental degradation, as outlined earlier in this paper, these challenges could be exacerbated in the coming decades if the business-as-usual development patterns were allowed to continue. Therefore, when the province began reforming Ontario's land-use planning system starting in 2003, it was done with the recognition that the GTA's influence and problems extend far beyond its political boundaries and that solutions to the above concerns had to be sought at a larger scale. A senior associate with the Ministry of Public Infrastructure and Renewal stated that there was a "realization that the province has to step in and think big picture [in terms of] regional planning" and that the government "can't just look at the GTA alone in a plan", but instead must "look at that inter-relationships of the region as a whole." (personal communication, April 12, 2006). From discussions with ministry staff, it became clear that through the Greenbelt and Growth Plans, the province intended to upscale urban-regional regulation within Southern Ontario from the level of the GTA to that of the Greater Golden Horseshoe. According to a manager at the MMAH, the province's thought process going into the planning reform exercise was that the GGH "is the right scale for the province to be involved in, because [they] don't want to duplicate what the Regions 
are doing, but nobody is looking at that inter-regional perspective, at least in any formal way" (personal communication, April 12, 2006). Through the Greenbelt and Growth Plans, the province has actively reinserted itself back into the regional planning process within Southern Ontario and in doing so, has begun restructuring the GGH region in a top down fashion. However, while these policies were designed to upscale traditional urban-regional regulation, the provincial government has stopped short of creating formal institutions at the city-regional scale to address governance issues (aside from Metrolinx); instead taking on the role of a regional government themselves.

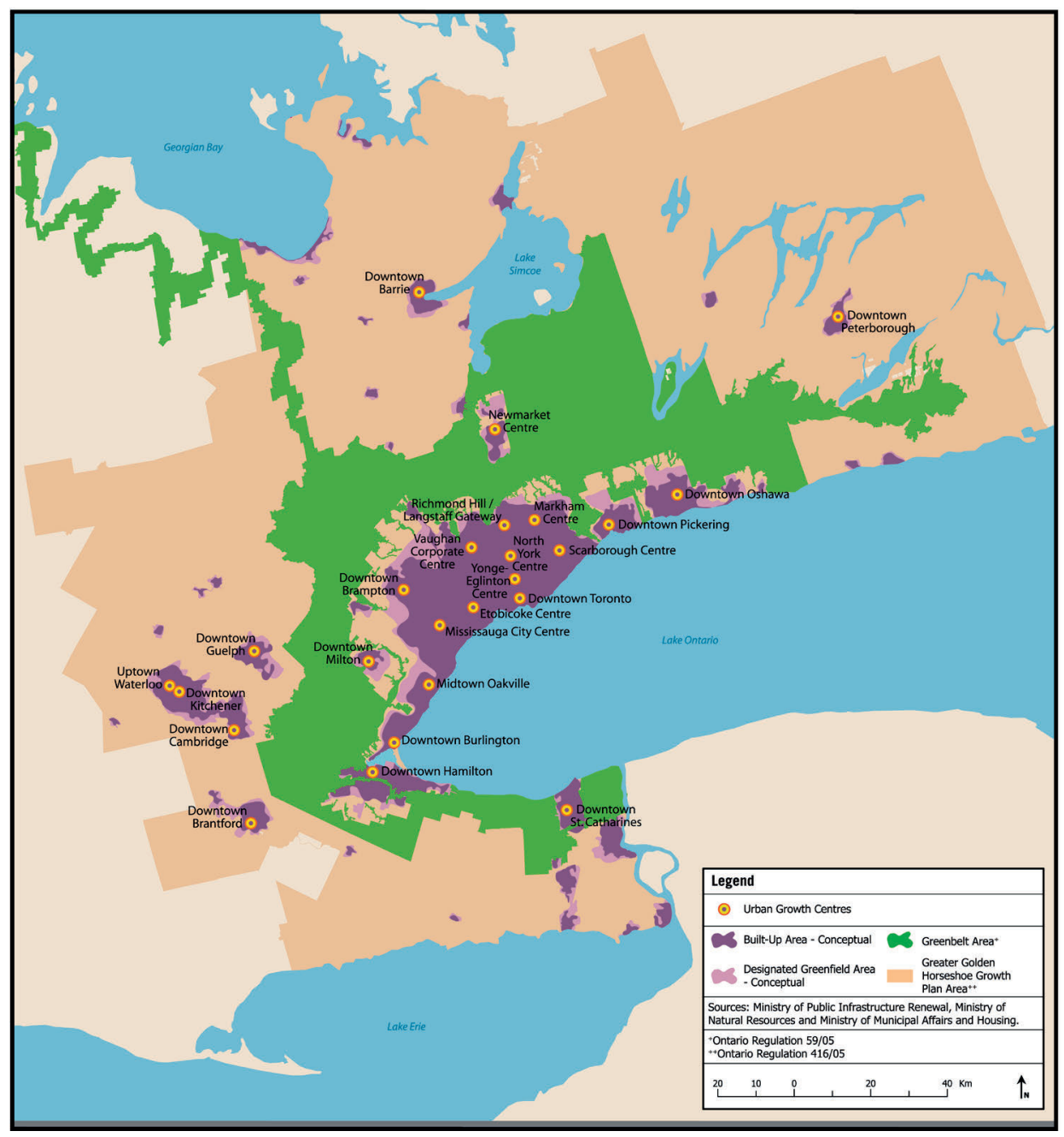

Figure 3.3: Urban Growth Centres in the Greater Golden Horseshoe Region

Source: Ministry of Public Infrastructure and Renewal, 2006 
One of the implications of this is that a number of the affected municipalities have felt that the process surrounding the creation of the Greenbelt and Growth Plan was undemocratic and they resented the imposition by the provincial government into their affairs. When the Greenbelt Plan was being finalized, many municipalities were very vocal about not supporting the plan because it either severely limited or halted their ability to expand urban areas for future development. However, a manager from the Ministry of Municipal Affairs and Housing has said that the provincial government wanted to "send a clear message that they [municipalities] can't always rely on greenfield growth forever to make their way in the world" (personal communication, April 12, 2006). While there have been (and continue to be) objections to the Greenbelt Plan, that same manager from the Ministry of Municipal Affairs and Housing also said that in principle, the municipal sector has been supportive because "big urban ones [municipalities] have been left to grow, while smaller ones never wanted to urbanize and [this plan] fits with their vision" (personal communication, April 12, 2006). Some municipalities have even taken the spirit behind the Greenbelt Plan a step further than the prescribed policies; for example in December 2009, Markham proposed an ambitious plan to protect farmland in a permanent 'foodbelt' within the town's borders that represents a significant shift from how other GTA municipalities view greenspace protection and urban sprawl (Gombu, January 9, 2010).

In addition to this mixed municipal reaction, the province made the municipalities responsible for implementing of the Greenbelt and Growth Plans and so far, this process has not been as integrated as provincial staff might have initially envisioned, as the implementation of the GGH Growth Plan is significantly behind schedule (Ontario Greenbelt Alliance, 2009). While the majority of upper tier municipalities have brought their Official Plans into compliance with the GGH Growth Plan, only six of eighty-nine lower tier municipalities had done so, as of July 2009 (ibid.). ${ }^{15}$ Also four municipalities (i.e. Durham, York, Niagara and Simcoe County) have either passed or drafted changes to their Official Plans that directly contradict the Places to Grow Act and leave natural areas at risk and susceptible to sprawl (ibid.). As the municipal reaction to and the implementation of these policies continues to be mixed, the province will have to continue to aggressively defend the Greenbelt and Growth Plan from future challenges that might threaten their integrity because there is no regional government or actor in place that can take on this role.

15 In Ontario, the municipalities are divided into different tiers or levels. A lower tier municipality refers to a town, township, city or village and is part of a higher level of municipal government. An upper tier municipality refers to a county, region or district and has a number of local municipalities within their jurisdiction. 
The provincial government has been given consistent praise by environmental organizations such as the Ontario Greenbelt Alliance for their efforts since 2003 to protect and promote this landscape (see Ontario Greenbelt Alliance, 2006; 2007). Since the creation of the Greenbelt Plan, the province has designated several additional parcels of provincially owned land within the greenbelt as protected parkland and they have taken a strong stand in support of its planning policies by intervening and defending challenges made by municipalities and developers to the plan in court (Ontario Greenbelt Alliance, 2007). By creating the greenbelt, the province has also guaranteed that the vital role provided by this landscape's ecosystems will be preserved into the future. The greenbelt also enjoys a high approval rating among GTA residents, as a 2006 survey indicates that 89 percent support this protected area as a way to ensure that cities remain liveable and sustainable (Monsebraaten, November 3, 2006). While Ontario's Greenbelt has come to be accepted and even celebrated by local governments, environmentalists, and the region's residents, not all of the groups involved in the greenbelt debate have had such positive response to this new landscape.

The region's agricultural communities are the single largest group affected by the greenbelt because of its direct and daily impact on their livelihoods and as a result, a representative from the Ontario Federation of Agriculture (OFA) has said that farmers are "the major stakeholder" in the greenbelt debate (personal communication, April 3, 2006) (Figure 3.4). However, the OFA felt that the importance of farming communities was not often recognized during the process to create the Greenbelt Plan and as a result, they strongly objected to the plan, calling it "the most draconian piece of legislation farmers in this Province [have] ever been faced with" (OFA, January 31, 2005). One of the primary objections that farmers had to the Greenbelt Plan is that it does not address the issue of the economic viability of farming. Agricultural communities within the province have faced a host of significant challenges in recent years including the effects of mad cow disease, increasing fuel costs and difficulty competing at the international scale because of a lack of government subsidies and the recent global recession (personal communication, April 3, 2006). These difficult circumstances could lead to farmers being forced into debt, taking other jobs, or selling their properties for development. The Greenbelt Plan provides an incomplete solution to the issues faced by farmers because while it protects agricultural land from urban encroachment, it also does not provide them with other means of support to make sure that their businesses survive and thrive. There are a number of measures that the province could take to assist farmers including promoting greenbelt grown products through buy local campaigns, investing in rural infrastructure and strengthening safety net programs to address problems such as the weather that are beyond a farmer's control (Ontario Fruit and Vegetable Growers Association, March 3, 2005). The Greenbelt Foundation has been active in promoting locally grown food. However there appears to be few other signs from the provincial government that they are willing to address the above issues and so for the 
time being, the economic viability of farming in the greenbelt remains a concern. The recently documented disappearance of animal agriculture such as beef, dairy and hog farming from the greenbelt highlights these concerns, as some farmers are relocating due to a lack of public and policy support for their businesses (Leeder, December 23, 2009). So while a representative the OFA says that their members recognize that "the preservation of agricultural land is important for their industry because there has been a longstanding concern that sprawl has been eating into a finite supply of agricultural land, they are not convinced that the greenbelt is the ideal solution to it" (personal communication, April 3, 2006).

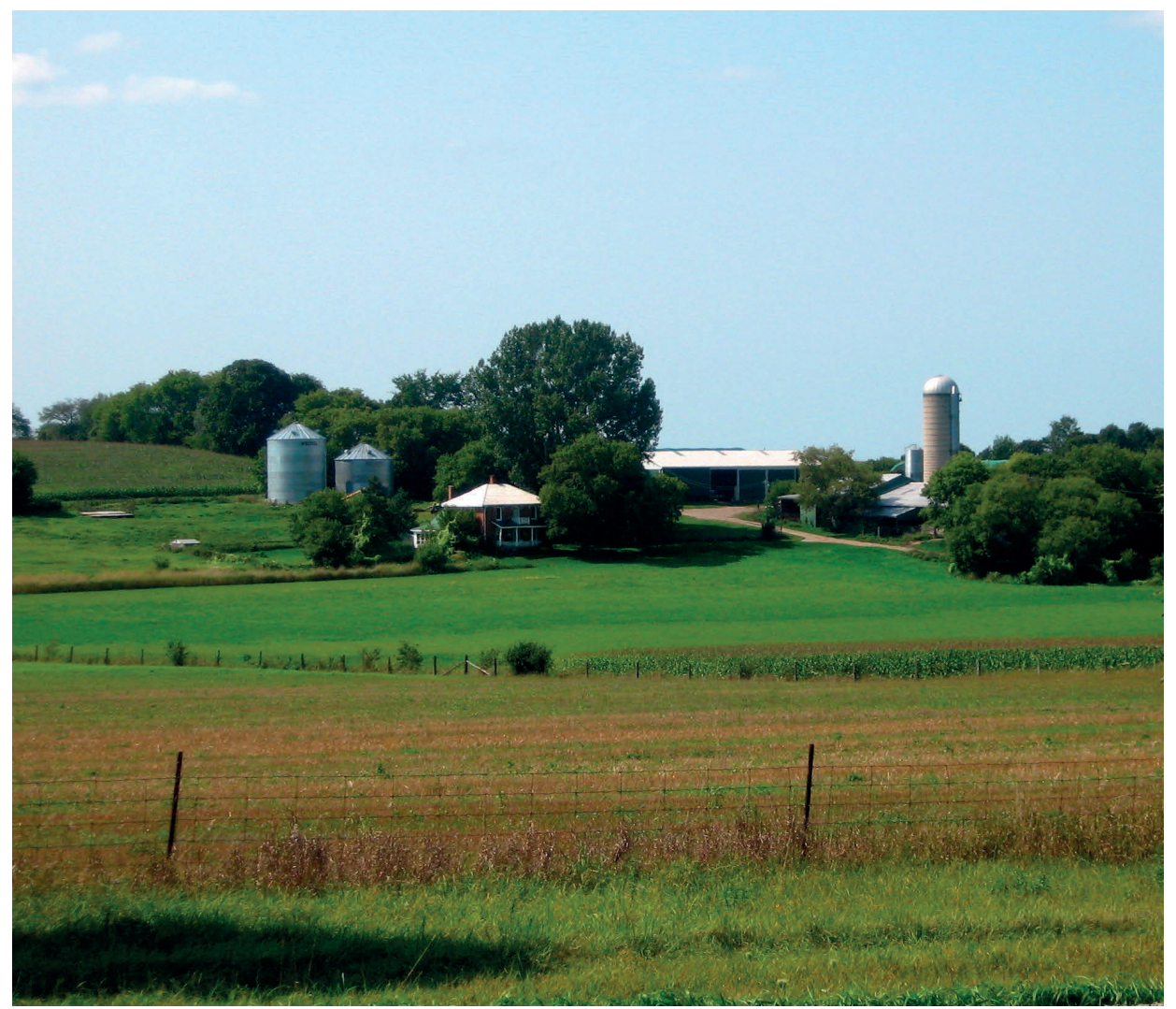

Figure 3.4: Agriculture in the Greenbelt (2009)

Source: Sara Macdonald

Similarly, to agricultural communities, the development industry in Ontario has been vocal in their objections to the Greenbelt and Growth Plans. The Urban Development Institute (UDI, which has now merged with the Greater Toronto Home Builders Association) was a lobby organization representing Ontario's development and construction industries. 
They had strong criticisms of the Greenbelt Plan when it was introduced, calling it "fundamentally flawed", containing "substantial mapping errors" and warning that the Plan will increase housing costs to such a degree that it will jeopardize Ontario's economic prosperity (UDI, 2005, 2; UDI, 2004). UDI questioned the rationale behind the location of the greenbelt's boundaries and a representative from this organization argued that the government produced none of the science (e.g. hydro-geological studies) behind the boundaries and that they were based on what they termed "political science, not 'sciencescience"' (personal communication, April 7, 2006). However, a manager from the Ministry of Municipal Affairs and Housing has said that constructing the boundaries of the greenbelt was not a science based exercise, but rather a planning one in which staff considered a number of factors such as growth projections, land supply estimates and the desire to build upon already protected areas such as the Oak Ridges Moraine, Niagara Escarpment, specialty crop areas and key natural heritage features (personal communication, April 12, 2006). The objections raised by the agricultural and development communities to the greenbelt's boundaries was not surprising when one considers the tremendous changes that the Greenbelt Plan has on their respective industries. The location of the greenbelt's boundaries determined if a farmer could sell their property for development or not, or if a developer had purchased land that could be turned into a new community or had to remain as greenspace. However, despite these objections, the region is expected to grow rapidly in the next 30 years and with that growth, there will be continued demand for new housing, so it will be interesting to see in the coming years how the development industry adapts to these recent policies changes and the impact that this will have on the region's land-use patterns.

The greenbelt also faces some difficult challenges in the years ahead. A report from the Canadian Institute for Environmental Law and Policy has compared the Ontario Greenbelt to international areas within North America and Europe that have greenbelts located by rapidly growing urban centres (see Carter-Whitney, 2008). Their analysis revealed that greenbelts face four common challenges: housing and urban development pressure, natural resource extraction pressures, protecting agriculture from urban encroachment and the construction of transportation infrastructure (ibid.). Of all these threats to greenbelts, the most prevalent one for the Ontario case study is that of the development pressures found within the Greater Golden Horseshoe region (Figure 3.5).

Since the greenbelt was proposed, numerous environmental organizations such as the Ontario Greenbelt Alliance have called on the province to expand the size of the greenbelt. They argue that the greenbelt is not large enough as it excludes over 50 percent $(675,000$ hectares) of the threatened greenlands in the Toronto Metropolitan Area (Ontario Greenbelt Alliance, n.d.) If these environmentally sensitive areas continue to remain 
without legislative protection, then this land could be threatened in the coming years by the development that could leapfrog over the greenbelt. When the Greenbelt Plan was introduced in 2005, it was predicted that Simcoe County could turn into a 'wild west' for development, as "there are developers literally at the gates of these communities who want to push urban sprawl over the Greenbelt" (Leong, June 22, 2005). Since that time, growth has leapfrogged over the greenbelt into this area as developers have placed pressure on towns such as Alliston, Clearview and Bradford-West Gwillimbury (Urquhart, December 5, 2007). As a result, there have been calls for the provincial government to expand the greenbelt, in part to protect communities from the potentially harmful impacts associated with a rapid population increases. In August 2008, the province released criteria to consider requests from regional, county and single tier governments to expand the greenbelt's boundaries, which would allow municipalities to identify areas within their jurisdictions that could become part of the greenbelt (MMAH, 2008). Since that time, a number of municipalities have proposed greenbelt expansions including Markham, Prince Edward County, Mississauga, Oakville, and Toronto (Greenbelt Alliance, 2010). By allowing municipalities the opportunity to expand the greenbelt, the province has shown their commitment to this legislation and seems willing to strengthen these policies when the need arises.

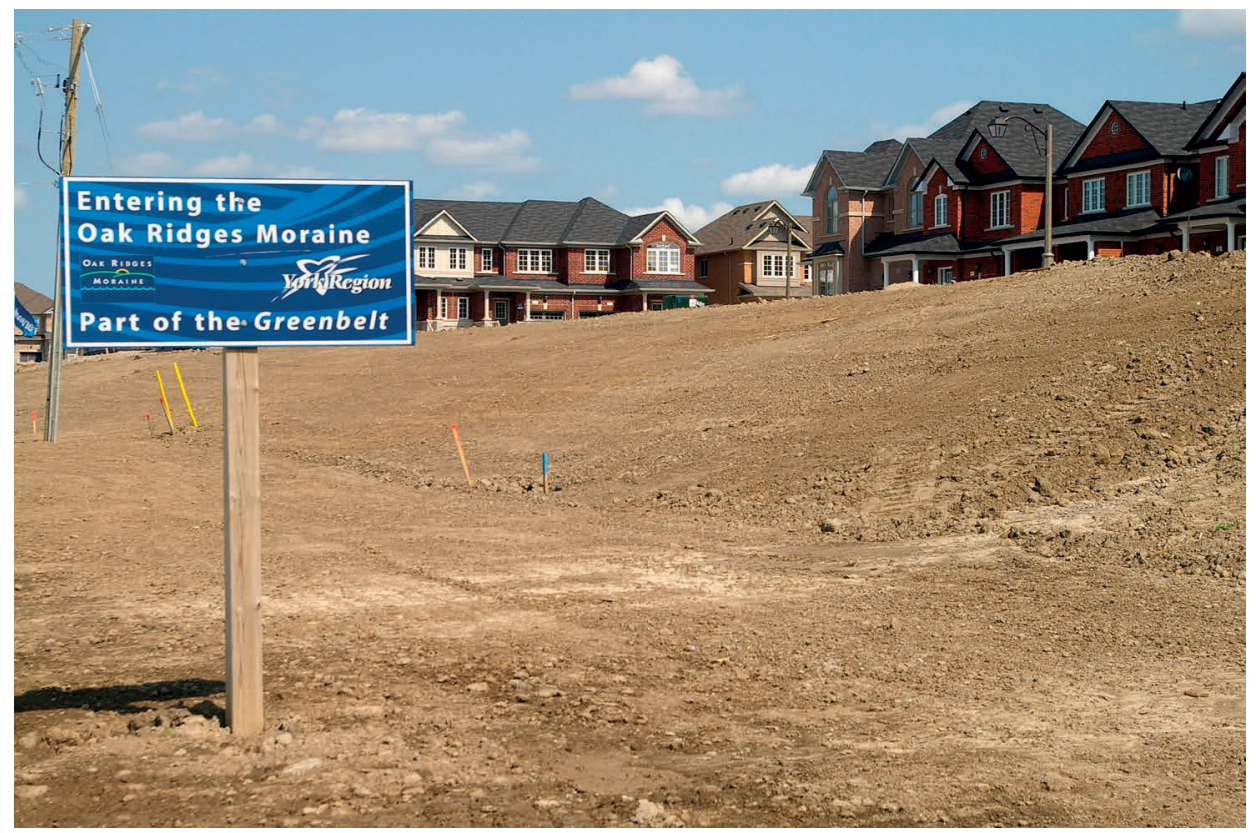

Figure 3.5: New Residential Development in the Greenbelt (2009)

Source: Roger Keil 
One area of the greenbelt policies that continues to be a key area of concern for environmentalists is the use of infrastructure within the greenbelt. The Greenbelt Plan allows for the creation and expansion of new infrastructure in protected areas provided that these facilities either a) "supports the agriculture, recreation and tourism, rural settlement areas, resource use or the rural economic activity that exists and is permitted within the Greenbelt" or b) "serves the significant growth and economic development expected in southern Ontario beyond the Greenbelt by providing for the appropriate infrastructure connections among urban growth centres and between these centres and Ontario's boarders" (MMAH, 2005a, 30). Therefore, infrastructure such as highways, water treatment operations, sewage systems, waste management facilities and aggregate operations can all be created or expanded in the natural heritage areas of the greenbelt, if the need for these uses can be demonstrated (MMAH, 2005a). There are several highway expansion plans currently proposed: the Mid-Peninsula Corridor, Highway 404 and Highway 407 East and each of these projects are continuing despite the fact that these roadways will cut through the protected areas of the greenbelt (Ontario Greenbelt Alliance, 2007). While it is necessary for municipalities to keep pace with future demands, a representative from the Ontario Greenbelt Alliance argued that "highway proposals do not support the direction and the whole idea behind the Greenbelt" as they encourage incompatible landuses and facilitate leapfrog development, which threatens the environmental integrity of the greenbelt (personal communication, April 3, 2006). While the decision to permit roads, sewers and other types of infrastructure in the greenbelt may be unpopular, a director with the Ministry of Municipal Affairs and Housing contended that they are a "necessary evil" and that there "has to be areas where these things happen" (personal communication, April 10, 2006). However, the Ontario Greenbelt Alliance (2007) states that if the province continues to allow the greenbelt to be fragmented by the expansion of infrastructure into its boundaries, than these policies could fail to serve as an effective regional growth management tool.

In addition to these development challenges facing the greenbelt, we are also interested in how managing this environment is being incorporated into regional governance structures. As mentioned previously, the environment can have a strong influence on regionalism, as Gibbs and Jonas $(2001,281)$ have argued that "the environment needs to be a key component of the economic development strategy for a region, rather than marginal to it". This is evidenced by the case of the GGH, since in addition to addressing unsustainable growth patterns, one of the key purposes of the Greenbelt and Growth Plans were to increase the economic competitiveness of the region. When designing the Growth Plan, a director with the Ministry of Public Infrastructure and Renewal said that they took the position that "the economic competitiveness and the future prosperity [of the GGH] is directly linked to how we grow" (personal communication, February 23, 2005). Therefore, one of the guiding principles of the 
plan is to "plan and manage growth to support a strong and competitive economy" (MPIR, $2006,10)$. Through the Greenbelt and Places to Grow legislation, the provincial government is trying to balance the sometimes-conflicting agendas of protecting the environment yet encouraging economic and population growth in the region. While et al. (2004) use the idea of a sustainability fix at the urban scale to show the dilemmas that governments are currently facing in balancing economic, social, and environmental concerns. However, the greenbelt takes this concept to another level as it represents a regional sustainability fix that is part of the provincial government's attempt to regulate socio-environmental relationships in the GGH. While et al. (2004) have found that government officials have used a variety of methods to organize sustainability fixes in their cities including developing partnerships with non-state actors, investing in a range of environmental policy initiatives, constraining antienvironmental behaviours and experimenting with alternative forms of economic activity and development. Through the Greenbelt and Growth Plan, the province has mandated an alternative form of development for the region that promotes the creation of mixed-use communities that differ from the low-density growth patterns that have characterized the GGH for decades, and has also made an effort to constrain anti-environmental practices by discouraging development in environmentally sensitive areas. Given the growth pressures and their environmental impact in the GGH, the province had to intervene in the region's growth politics and in doing so, has clearly "fixed" these issues at a new scale not seen before in Southern Ontario.

In light of the above discussion, there are two issues to keep in mind about the Greenbelt and Growth Plans. First, these policies are only a few years old, so it will take time to see the results of these initiatives. A manager with the Ministry of Municipal Affairs and Housing said that the province purposely left a portion of land (i.e. the controversial so-called 'whitebelt') between the southern boundary of the greenbelt and the northern edge of urban development for future growth (personal communication, April 10, 2006). Urban expansion can continue for decades on the 146,000 hectares of land in the 'whitebelt' before reaching the southern edge of the greenbelt (Neptis Foundation, 2005). Also, the PPS requires that planning authorities maintain a minimum of a 10-year supply of land for residential growth (MMAH, 2005c). Therefore, land that was purchased and approved for development before the Greenbelt and Growth Plans came into effect would still be subject to the old policies and thus it could take years to see the impact that these recent policies will have at the ground level. Second, a representative from the Ontario Greenbelt Alliance argued that the "Greenbelt alone is not enough to stop sprawl. It has to be taken in consideration with the other policies and initiatives that are going ahead" (personal communication, April 3, 2006). While changes to the provincial land-use planning system are well underway through amendments to the Planning Act, the release of an updated PPS and OMB reforms, there are other initiatives that are necessary to support the Greenbelt and Growth Plan. In November 2008, Metrolinx 
released "The Big Move" a long-term strategic regional transportation plan for the Greater Golden Horseshoe and this plan, along with the Greenbelt and Growth Plans, are designed to create compact and sustainable communities (see Metrolinx, 2008). However, more work still needs to be done to ensure that the region's agricultural sector remains productive and the province could assist this community by developing programs that reward farmers for the effective environmental management of their lands and supporting farmers who want to develop businesses related to agriculture (Carter-Whitney, 2008). The province has demonstrated strong commitments towards addressing the environmental, social, and economic impacts of existing development patterns within the region. However, it will take years and the continued support of all parties involved to create the more sustainable communities envisioned for Ontario.

\subsection{CONCLUSION}

We have argued here that extended metropolitanization in Southern Ontario has been a process, which has brought nature, the state, and governance together into a new constellation of a regional sustainability fix. The new regionalism practiced by Ontario's Liberal government has meant since its inception in 2003 that regional environments are considered central to the growth of the competitive Greater Golden Horseshoe. We have demonstrated that the Ontario government, by creating super-regional land use legislation, has up scaled the conflict around political regulation of the Toronto region to the level of a new unit: the Greater Golden Horseshoe. In doing so, the provincial government, with the support of important environmental groups, in particular the Ontario Greenbelt Alliance, Earthroots, Ontario Nature and the Toronto Environmental Alliance, has effectively downgraded and pacified previous contestations between the core of the metropolitan area (416) and the suburbs (905). By enlarging their policy framework in this manner, the province has been able to break a political stalemate that has existed since the acrimonious debates around municipal reform in the 1990s. Of importance in this context was that the geographical "upscaling" went along with a 10-year moratorium on development in the greenbelt, while growth is simultaneously accelerated and concentrated in the Places to Grow Act. In contrast to previous governments that had facilitated sprawl and development through market liberalization, the Liberal provincial government of Ontario in recent years has 'rationalized' the impact of growth and reinserted the state firmly into the process. In addition, while the Tory government had de-democratized and privatized the planning process, the Liberals opened governance of large territories in the province explicitly to civic organizations, non-elected special purpose bodies that have broad support in the general population and are tied in with more than just a narrow class of property developers in the region. 
Although the current government has not engaged in redistributive strategies to address the income and public expenditure gaps between the inner city and the exurbs, and it has lagged behind its ambitious implication strategy (Ontario Greenbelt Alliance, 2009), it has redefined the conflicts around growth along new lines: with the Places to Grow Act that accompanies Greenbelt legislation. All areas not in the greenbelt (and not just the inner city of Toronto) will have to shoulder part of the growth pressures of the expected demographic and economic expansion over the next generation. This effectively urbanizes the suburbs (which are also part of the growth area) and is set up to protect rural and agricultural land from sprawl. Besides being a deliberate up-scaling of the urban-regional problematic, this development can also be discussed as a sustainability fix at the regional level as now the attempts to come to terms with growth pressures and their environmental impact are clearly fixed at the regional level. It is peculiar, of course, that this happens precisely without creating a new political or jurisdictional unit of government at that scale outside the Places to Grow and Greenbelt legislations. Once again, as has been the case through most of the history of regional governance in Ontario (Frisken, 2007), the province has taken on the role not just of regional regulator but also of regional government in absentia.

The current Greenbelt legislation represents both a continuation and a break in Ontario land use policy. In this sense, we can conclude that it is a complex piece of legislation, which is both a directive and platform for further state and civic action, and a comprehensive set of regional governance measures by provincial government. Thus, we can argue that it is many competing and complementary things at once:

It is first and foremost an object and result of a politics of scale through which the Ontario government scaled up existing and long lasting regional governance by taking the reins firmly in their hands and creating clear and reliable legal frameworks for conservation on one hand and development on the other for a reasonable time frame (Wekerle et al., 2007). As a government intervention, it is a "policy of scale". The greenbelt (and its complement, the Places to Grow) legislation is also a state spatial strategy and project which orders state space in southern Ontario anew. As a state project, it has given a framework to government departments, municipalities, and other state actors, who must adapt and implement regional planning policy to specific communities and sites. The dissemination of the strategy has largely been a top-down affair with orchestrated participation - a rearrangement of territorial powers organized by the government. New instruments of participation have been created, most importantly the Greenbelt Foundation, whose mission it is "to promote and sustain our Greenbelt as a beneficial, valuable, and permanent feature, enhancing the quality of life for all residents of Ontario." (Friends of the Greenbelt Foundation, n.d.). Despite the orchestrated nature of its implementation as a state strategy, the greenbelt has to be seen as a territorial compromise (Schmid, 1996). Its existence needs to be seen 
as a result of long-standing conflicts around the regulation of space in Southern Ontario precisely at a time of heightened restructuring pressure in the region. The Greenbelt Act and the Places to Grow Act provide a truce in those conflicts, which allows structural actors to pause but act strategically when needed in the future. The Greenbelt legislation is therefore to be understood as an instrument of extended metropolitanization, i.e. it orders a large urban region in a traditional and path-dependent fashion that extends the logic of metropolitanism (infrastructure, etc.) to traditionally rural areas. Instead of opening the region up to sprawl as usual, it regulates development of these areas in ways that are compatible with the growing environmental sensitivities of urban populations. In this sense, the greenbelt (along the Places to Grow legislation) is an urban plan through which the city organizes the countryside. What it also does, though, in contrast to previous, Toronto-centred pieces of legislation, is take into account the polycentric realities of a postFordist, Zwischenstadt- landscape of the Toronto region (Sieverts, 2003). It is not just a belt around one dominant centre but curls geographically and thematically around an entire array of "places to grow" between Niagara and the eastern central edge of Lake Ontario, between the winelands of the south and the northern reaches of the Niagara Escarpment. Finally, as an inverted growth plan, it is an attempt at spatial ecological modernization, a regional sustainability fix, which - for at least the period of ten years, fastens the regional political ecology in a legal and planning framework which will determine the terms of the conflict around environmental territories in Southern Ontario.

This way, the current Ontario greenbelt narrative tells adds a $21^{\text {st }}$ century chapter to the century-old greenbelt debate. The traditional concept of the greenbelt dates back to the $19^{\text {th }}$ century and Ebenezer Howard's concept of the Garden City, whereby greenbelts were supposed to create distinct boundaries between rural and urban spaces and preserve the countryside (Carter-Whitney, 2010). However, over time, the roles of greenbelts have evolved and now greenbelts are designed to protect agricultural land, natural heritage features, environmentally significant areas, and act as urban growth boundaries. As was discussed in this paper, at the start of the $21^{\text {st }}$ century, greenbelts are facing a host of new challenges and land-use conflicts and as such, may be doing more than their predecessors.

Greenbelts may become increasingly important in coming years due to global conditions such as climate change, water scarcity, escalating oil prices, and concerns about food security (ibid.). They have the potential to mitigate some of negative impacts associated with climate change through increasing the amount of carbon stored in soils and trees, contributing to reducing the urban heat island effect and reducing flood risks in areas around cities (The Campaign to Protect Rural England and Natural England, 2010). Also, policy measures such as greenbelts that encourage locally grown food can reduce the transportation costs and distances of food production, which can help to make a community more self-sufficient 
(ibid.). Greenbelts also provide a range of environmental benefits. A report by the David Suzuki Foundation has found that the value of these ecosystem services provided by the Ontario greenbelt such as water filtration, pollination, flood control, wildlife habitat, carbon storage and waste treatment are worth an estimated $\$ 2.6$ billion annually and $\$ 8$ billion since its establishment in 2005 (Wilson, 2008). However, greenbelts also can exacerbate some of these same conditions since they can encourage leapfrog development, which increases commuting times and emission levels and contributes to climate change. It is clear that the role of greenbelts is changing, and it is only just beginning to be understood both the positive and negative impacts that these protected spaces could have on future populations. Although it is impossible to predict the ways that the Ontario greenbelt can address future challenges that may arise, the examples presented here highlight that this landscape has the potential to become increasingly important in the coming years. 


\subsection{REFERENCES}

Ali, A. K. (2008). Greenbelts to contain urban growth in Ontario, Canada: Promises and prospects. Planning, Practice \& Research, 23(4), 533-548.

Boudreau, J. A., Hamel, P., Jouve, B., \& Keil, R. (2006). Comparing metropolitan governance: The cases of Montreal and Toronto. Progress in Planning, 66(1), 7-59.

Boudreau, J. A., Hamel, P., Jouve, B., \& Keil, R. (2007). New state spaces in Canada: Metropolitanization in Montreal and Toronto compared. Urban Geography, 28(1), 30-53.

Brenner, N. (2002). Decoding the newest "metropolitan regionalism" in the USA: A critical overview. Cities, 19(1), 3-21.

Carter-Whitney, M. (2008). Ontario's greenbelt in an international context: Comparing Ontario's greenbelt to its counterparts in Europe and North America. Canadian Institute for Environmental Law and Policy. Retrieved from http://www.cielap.org/pdf/GreenbeltInternationalContext.pdf

Carter-Whitney, M. (2010). Ontario's greenbelt in an international context. The Friends of the Greenbelt Foundation. Retrieved from http://www.greenbelt.ca/webfm_send/622

Collin, J.-P. and Robertson, M. (Eds.) (2007). Governing metropolises: Profiles of issues and experiments on four continents. Quebec City, QB: Les Presses de I'Université Laval.

Crombie, D. (1992). Regeneration: Toronto's waterfront and the sustainable city. Toronto, ON: The Royal Commission on the Toronto Waterfront.

Desfor, G. and Keil, R. (2004). Nature and the city: Making urban environmental policy in Toronto and Los Angeles. Phoenix, AZ: University of Arizona Press.

Friends of the Greenbelt Foundation. (n.d.). Vision, mission and goals. Retrieved from http://www. ourgreenbelt.ca/foundation/vision-mission-goals

Frisken, F. (2007). The public metropolis: The political dynamics of urban expansion in the Toronto region, 1924-2003. Toronto, ON: Canadian Scholars' Press.

Fung, F., \& Conway, T. (2007). Greenbelts as an environmental planning tool: A case study of southern Ontario, Canada. Journal of Environmental Policy and Planning, 9(2), 101-117.

Gibbs, D. (2006). Prospects for an environmental economic geography: Linking ecological modernization and regulationist approaches. Economic Geography, 82(2), 193-215.

Gibbs, D., \& Jonas, A. E. (2000). Governance and regulation in local environmental policy: The utility of a regime approach. Geoforum, 31(3), 299-313.

Gombu, P. (2010, January 9). Food before suburbia; developers frustrated by a Markham initiative to freeze town farmland, create denser housing. The Toronto Star, p. GT. 1

Heinelt, H., \& Kübler, D. (2004). Metropolitan governance in the 21st century: Capacity, democracy and the dynamics of place. Milton Park, England: Routledge.

Hemson Consulting Ltd. (2005). The growth outlook for the Greater Golden Horseshoe. Retrieved from http://www.hemson.com/news/GrowthOutlookorGGH\%2017Jan2005a.pdf

IBI Group. (2002). Toronto-related region futures study. Interim report: Implications of business-asusual development. The Neptis Foundation. Toronto, Canada.

Jonas, A. E., \& Gibbs, D. C. (2003). Changing local modes of economic and environmental governance in England: A tale of two areas. Social Science Quarterly, 84(4), 1018-1037.

Jonas, A. E., While, A., \& Gibbs, D. C. (2004a). State modernisation and local strategic selectivity after local agenda 21: Evidence from three northern English localities. Policy \& Politics, 32(2), 151-168. 
Jonas, A. E., While, A., \& Gibbs, D. C. (2004b). Uneven development, sustainability, and cityregionalism contested: English city-regions in the European context. In Halkier, H. and Sagan, I. (Eds.). Regionalism contested: Institution, society and territorial governance, (pp. 223-243). London, England: Ashgate.

Keil, R. and Mahon, R. (Eds.) (2009). Leviathan undone? Towards a political economy of scale. Vancouver, BC: UBC Press.

Keil, R., \& Young, D. (2008). Transportation: The bottleneck of regional competitiveness in Toronto. Environment and Planning C: Government and Policy, 26(4), 728-751.

Leeder, J. (2009, December 23). Greenbelt tension drives farmers out. The Globe and Mail, p. A1.

Leong, M. (2005, June 22). Simcoe activists fear builders will leapfrog greenbelt. National Post, p. A15.

Mahon, R. and Keil, R. (2009). Introduction. In Keil, R. and Mahon, R. (Eds.) (2009). Leviathan undone? Towards a political economy of scale. (pp. 3-23). Vancouver, BC: UBC Press.

Metrolinx. (2008). The big move: Transforming transportation in the Greater Toronto and Hamilton area. Retrieved from http://www.metrolinx.com/Docs/big_move/TheBigMove_020109.pdf.

Ministry of Municipal Affairs and Housing. (2004). Towards a Golden Horseshoe greenbelt. Greenbelt task force. Discussion paper: A framework for consultation. Toronto, ON: Queen's Printer for Ontario.

Ministry of Municipal Affairs and Housing. (2005a). Greenbelt plan, 2005. Toronto, ON: Queen's Printer for Ontario.

Ministry of Municipal Affairs and Housing. (2005b). Ontario government strengthens role of local councils and residents in community planning. Retrieved from http://www.mah.gov.on.ca/ userfiles/HTML/nts_1_25823_1.html

Ministry of Municipal Affairs and Housing. (2005c). The provincial policy statement. Toronto, ON: Queen's Printer for Ontario.

Ministry of Municipal Affairs and Housing. (2006). The strong communities (planning amendment) act, 2004 (bill 26). Retrieved from http://www.mah.gov.on.ca/userfiles/HTML/nts_1_16239_1. html

Ministry of Municipal Affairs and Housing. (2008). Growing the greenbelt. Retrieved from http:// www.mah.gov.on.ca/AssetFactory.aspx?did=5767

Ministry of Public Infrastructure and Renewal. (2005). Places to grow act, 2005. Toronto: Legislative assembly of Ontario. Retrieved from http://www.ontla.on.ca/documents/Bills/38_Parliament/ Session1/b136rep_e.htm

Ministry of Public Infrastructure and Renewal. (2006). Places to grow. Better choices. Brighter future. Growth plan for the Greater Golden Horseshoe 2006. Retrieved from http://www.pir.gov.on.ca/ english/growth/gghdocs/FPLAN-ENG-WEB-ALL.pdf

Monsebraaten, L. (2006, November 3). New poll supports greenbelt. 89\% of residents favour curbing urban sprawl and results suggest voters behind green agenda. The Toronto Star, p. C1.

Neptis Foundation. (2005). Neptis commentary on the draft greenbelt plan. Retrieved from http://209.200.93.249/library/show.cfm?id=67\&cat_id=30

Ontario Federation of Agriculture. (2005, January 31). O.F.A. vice-president Paul Mistele comments to the standing committee on general government bill 135. Retrieved from http://www.ofa.on.ca/ whatwedo/lobby/correspondence/2005/january/Paul\%20Mistele\%20-\%20Comments\%20 on\%20General\%20Government\%20Bill\%20135.pdf

Ontario Fruit and Vegetable Growers Association. (2005). Let's work on getting the greenbelt right for all. Retrieved from http://www.ofvga.org/communications.php 
Ontario Greenbelt Alliance. (n.d). Greenbelt alliance presentation to legislative standing committee reviewing bill 135, the greenbelt act. Retrieved from http://www.greenbelt.ca/reports/ Standing\%20Committee\%20Brief\%20-\%20Bill\%20135.pdf

Ontario Greenbelt Alliance. (2006). Greenbelt report card: Grading implementation and progress in year 1. Retrieved from http://www.environmentaldefence.ca/reports/Grading\%20the\%20 GreenbeltFINAL.pdf

Ontario Greenbelt Alliance. (2007). Greenbelt report card: 2nd anniversary edition. Retrieved from http://www.greenbelt.ca/reports/GreenbeltReportCard_FINAL_embargoed.pdf

Ontario Greenbelt Alliance. (2009). Places to sprawl. Report on municipal conformity with the growth plan for the Greater Golden Horseshoe, as provided for under Ontario's places to grow act. Retrieved from http://environmentaldefence.ca/reports/pdf/PlacesToSprawl.pdf

Ontario Greenbelt Alliance. (2010). Green among the grey. Fifth anniversary progress report on the Greater Golden Horseshoe greenbelt. Retrieved from http://greenbeltalliance.ca/files/pdf/ GreenbeltProgressReportFINAL.pdf

Ontario Growth Secretariat. (2005). Urban growth centres in the Greater Golden Horseshoe. Ministry of Municipal Affairs and Housing. Retrieved from http://www.pir.gov.on.ca/userfiles/page_ attachments/Library/4/UGC_TechnicalPaper_Winter05_Feb.pdf?N_ID=4

Paasi, A. (2003). Region and place: Regional identity in question. Progress in Human Geography, 27(4), 475-485.

Paasi, A. (2004). Place and region: looking through the prism of scale. Progress in Human Geography, 28(4), 536-546.

Schmid, C. (1996). Urbane region und territorialverhältnis -Zur regulation des urbanisierungsprozesses. In Bruch, M. and Krebs, H.P. (Eds). Unternehmen globus. (pp. 224-253). Münster, Germany: Verlag Westfälisches Dampfboot.

Sieverts, T. (2003). Cities without cities: An interpretation of the zwischenstadt. New York, NY: Spon Press.

The Campaign to Protect Rural England and Natural England. (2010). Green belts: A greener future. Retrieved from http://www.cpre.org.uk/campaigns/planning/green-belts/green-beltscampaign-update

Urban Development Institute. (2004). Urban development institute/ Ontario submission. Re: bill $27-$ greenbelt protection act, 2003. Retrieved from http://www.udiontario.com/Submissions/2004/ Bill27_EBR_Submission_040323.pdf

Urban Development Institute. (2005). Urban development institute/ Ontario remarks to the standing committee on general government. Re: bill 135 - greenbelt act, 2004. Retrieved from http:// www.udiontario.com/Submissions/2005/Bill135_Presentation_SCGeGov_050131.pdf

Urquhart, I. (2007, December 5). The battle for Simcoe county. The Toronto Star. p. A22.

Wekerle, G. R., Sandberg, L. A., Gilbert, L., \& Binstock, M. (2007). Nature as a cornerstone of growth: Regional and ecosystems planning in the Greater Golden Horseshoe. Canadian Journal of Urban Research, 16(1), 20-38.

Wekerle, G., Sandberg, A., and Gilbert, L. (2009). Regional resistances in an exurban region: Intersections of the politics of place and the politics of scale, In Keil, R. and Mahon, R. (Eds.). (2009). Leviathan undone? Towards a political economy of scale. (pp. 247-264). Vancouver, BC: UBC Press.

While, A., Jonas, A. E., \& Gibbs, D. (2004). The environment and the entrepreneurial city: Searching for the urban 'sustainability fix' in Manchester and Leeds. International Journal of Urban and Regional Research, 28(3), 549-569. 
Whitehead, M. (2008). Cold monsters and ecological leviathans: Reflections on the relationships between states and the environment. Geography Compass, 2(2), 414-432.

Whitehead, M., Jones, M., \& Jones, R. (2006). Spatializing the ecological leviathan: Territorial strategies and the production of regional natures. Geografiska Annaler: Series B, Human Geography, 88(1), 49-65.

Whitehead, M. (2007). The nature of the state: Excavating the political ecologies of the modern state Oxford geographical and environmental studies series. Oxford, England: Oxford University Press.

Wilson, S. (2008). Ontario wealth, Canada's future: Appreciating the value of the greenbelt's eco-services. David Suzuki Foundation. Retrieved from http://www.ourgreenbelt.ca/sites/ ourgreenbelt.ca/files/DSF-Greenbelt-Web1.pdf

Winfield, M. (2005). Building sustainable urban communities in Ontario: A provincial progress report. The Pembina Institute. Retrieved from http://www.pembina.org/pdf/publications/sg-update05final-lo.pdf

Winfield, M. (2003). Smart growth in Ontario: The promise vs. provincial performance. The Pembina Institute. Retrieved from http://www.pembina.org/pdf/publications/smartgrowth030307.pdf

Young, D., \& Keil, R. (2010). Reconnecting the disconnected: The politics of infrastructure in the inbetween city. Cities, 27(2), 87-95. 



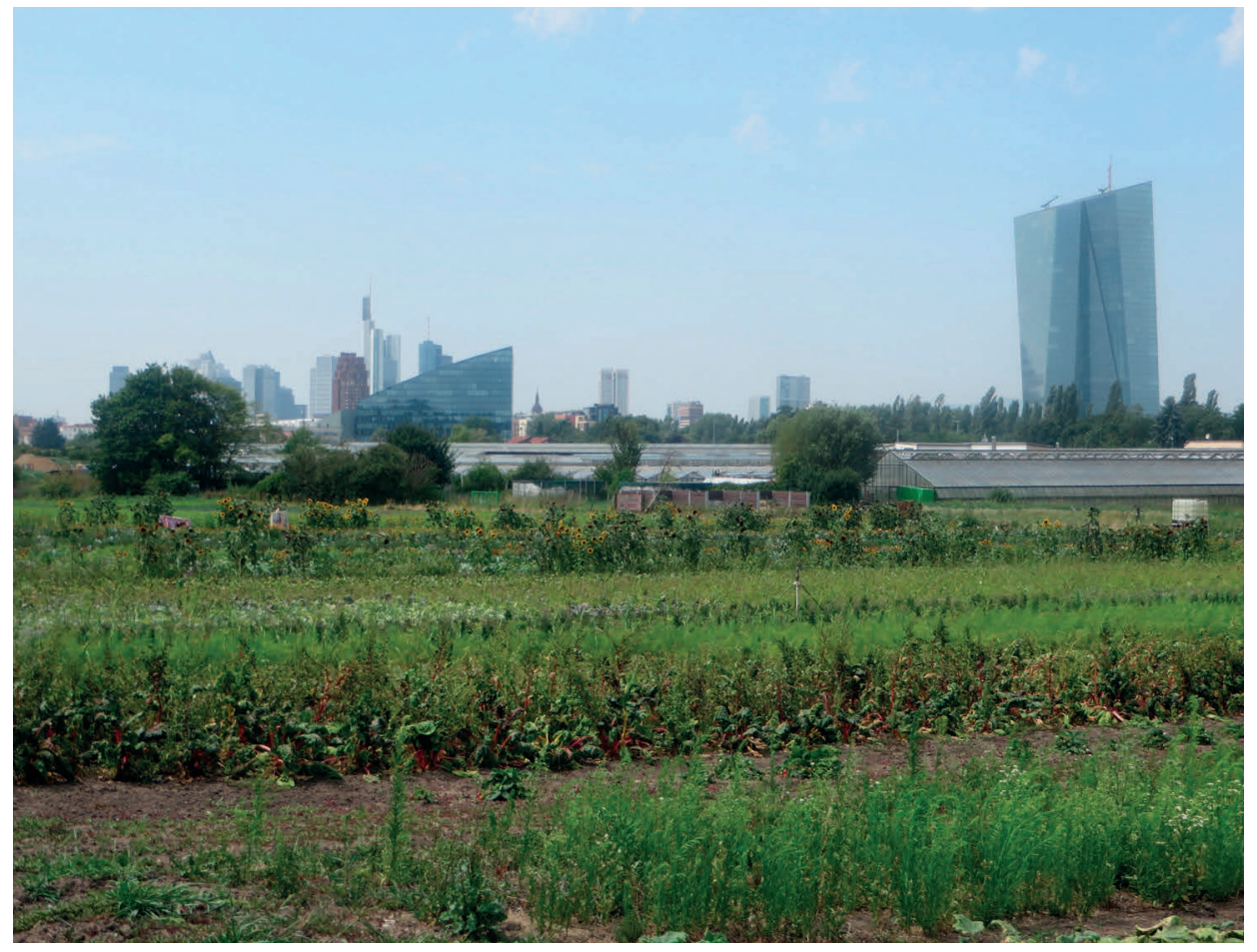

Frankfurt Greenbelt, Oberrad neighbourhood (2015). Herbs for the region's traditional green sauce (Grüne Soße) are grown in this area.

Source: author 


\title{
From the Frankfurt Greenbelt to the Regionalpark RheinMain:
}

\author{
An institutional perspective on \\ regional greenbelt governance
}

Published as Macdonald, S., Monstadt, J., \& Friendly, A. (2020). From the Frankfurt greenbelt to the Regionalpark RheinMain: an institutional perspective on regional greenbelt governance. European Planning Studies. Doi: 10.1080/09654313.2020.1724268 


\section{ABSTRACT}

Legally protected by its own constitution since 1991, the greenbelt (or GrünGürtel) forms a ring of greenspace around Frankfurt, Germany and has been considered an effective reaction to municipal development pressures. As a response to Frankfurt's embeddedness within a highly interconnected suburbanized region under extensive growth pressures, the Regionalpark RheinMain was established to upscale the greenbelt to the regional level. In this article, we explore the institutional complexities of upscaling a localized greenbelt to the regional scale in the Frankfurt Rhine-Main region, which is known for its fragmented institutional environment formed by numerous planning authorities and special purpose agencies with overlapping jurisdictions. Engaging with the literature on the governance of greenbelts from an institutional perspective, we analyse how the development of the Regionalpark RheinMain is shaped by horizontal, vertical, and territorial coordination problems. We conclude that that the Regionalpark RheinMain is not appropriately institutionalized to serve as an effective regional greenbelt, resulting in localized initiatives and the delegation of greenbelt planning to municipalities.

\section{Keywords}

greenbelts, regional governance, Regionalpark RheinMain, Frankfurt Rhine-Main region, institutions. 


\subsection{INTRODUCTION}

This article presents an institutional approach to explore the governance of regional greenbelts. By focusing on the institutional dimensions of regional governance and applying concepts of horizontal, vertical and territorial coordination to this research, this article aims to enrich regional governance literature both empirically, by focusing on regional greenbelts, and conceptually, through systematically addressing institutional problems in regional governance. To illustrate this argument, we explore a case study of regional greenspace planning in the Frankfurt Rhine-Main region which has been upscaled from the municipal Frankfurt greenbelt (or GrünGürtel) to the metropolitan Regionalpark RheinMain. Legally protected by its own constitution since 1991 and supported by nature conservation regulations, the Frankfurt greenbelt has been a successful response to municipal development pressures. However, this municipal greenbelt now hardly reflects Frankfurt's embeddedness within a regionalised suburban environment-a sprawling landscape in-between a network of cities that form the Frankfurt Rhine-Main region. This polycentric region can best be characterized by what Sieverts (2003) calls an "urbanized landscape" or a "landscaped city" - a mixture of developed and open spaces at the regional scale, under intense growth pressures that have recently been amplified by Brexit. This urban region, combining peripheral development and strong inter-municipal competition with a regional division of labour, faces considerable planning challenges: including the containment of development within its "system of central places" and along regional growth and transportation corridors and as Germany's main transportation hub. Within Frankfurt Rhine-Main's suburban landscape, the municipal greenbelt can no longer be regarded as an effective solution for urban growth containment. Consequently, the Regionalpark RheinMain was established in 1994 with a mandate to safeguard regional greenspaces. The formation of the localized Frankfurt greenbelt has attracted academic attention (Husung and Lieser, 1996; Wei, 2017), while the Regionalpark RheinMain has been analysed regarding its policy ambitions but not the institutional challenges shaping its implementation (Dettmar, 2012; Rautenstrauch, 2015). However, the Frankfurt RhineMain region's ambition to establish a regional greenbelt is particularly complex. As spatial strategies, the development of the regional greenbelt reveals key regional governance challenges. It requires not only a regulation of city-hinterland relationships but also between diverse interests associated with greenspace usage. These interests can range from providing recreational facilities, enabling new development and agriculture. From an institutional perspective, the governance of regional greenbelts overarches territorial jurisdictions of multiple municipalities and the Greater Frankfurt Planning Authority; it requires the coordination of multiple policy domains (e.g., nature conservation, land-use planning and transportation), private stakeholders and non-governmental organizations; and is shaped by policies from the municipal to the regional state (Länder) levels. The 
regional governance challenges resulting from this "new generation" of greenbelt schemes thus involve complex institutional problems of horizontal, vertical, and territorial coordination that have rarely been addressed in existing literature.

While some literature reflects the regionalism of greenbelts (Addie and Keil, 2015; Macdonald and Keil, 2012), the institutional complexities of regional governance are usually not discussed, with some exceptions (Röhring and Gailing, 2005). Therefore, we address this literature gap and bring together three concepts of institutional coordinationhorizontal, vertical, and territorial-to explore how the governance of greenbelts is shaped by their institutional environments. Based on an empirical case study of the Regionalpark RheinMain, the objective of this article is to explain how the governance of regional greenbelts is challenged by institutional arrangements within the Frankfurt Rhine-Main region. Thus, we ask: how could the development of the Regionalpark RheinMain be more effectively coordinated between different policy domains and their related stakeholders at multiple policy levels and across various municipal and special purpose agency jurisdictions? What lessons could be drawn for policymakers to improve greenbelt planning and for regional governance debates?

We examine these issues using a case study of regional greenspace planning in the Frankfurt Rhine-Main region, which has a reputation for its complex spatial planning system. This empirical research is based on a review of regional and state policy documents and promotional material about the Frankfurt greenbelt and the Regionalpark RheinMain. This was complemented by 37 interviews within the Frankfurt Rhine-Main region (September 2017-July 2019) with representatives from local, regional, and state governments, environmental organizations, and special purpose bodies. These interview participants were selected because they include all major interest groups involved in the Frankfurt greenbelt and Regionalpark RheinMain's management. Discussions focused on how these greenspaces' policy implementation has been influenced by coordination challenges between stakeholders at multiple policy levels and across numerous policy domains and municipalities' jurisdictions. Using our conceptual framework, an analysis of the empirical literature was used to identify how the region's institutional environment shapes greenbelt management. This article is organized as follows. First, we provide an overview of literature on the governance of greenbelts focusing on institutional dimensions, and introduce the conceptual framework applied to this research. Next, the governance and the institutional set-up of the Frankfurt greenbelt and Regionalpark RheinMain is outlined. Through a discussion of horizontal, vertical and territorial institutional coordination, we argue that the Regionalpark RheinMain is not appropriately institutionalized to serve as an effective regional greenbelt, resulting in activities being downscaled to the local level and the delegation of greenbelt planning to municipalities. 


\subsection{FROM URBAN TO REGIONAL GREENBELTS}

Urban regions around the world have responded to problems associated with rapid urbanization by developing numerous land-use policies to manage urban growth. Among those policies, the development of greenbelts has been an important approach to retain farmland and conservation areas surrounding cities. Greenbelts are designed to prevent urban sprawl by keeping undeveloped areas permanently open, to protect land for farming and recreation, and to conserve natural habitats (Amati, 2008). The greenbelt concept is based on Ebenezer Howards' Garden City idea with a focus on city-countryside separation and preserving greenspaces (Sturzaker and Mell, 2017). Following their 1930s introduction in UK planning policy, greenbelt principles spread internationally to locations such as Seoul, Melbourne, Toronto, and Frankfurt (ibid.).

In recent decades, a "new generation" of greenbelts has emerged from those UK policies which is based less on an industrial past, instead forming multi-purpose policy frameworks. Going beyond the traditional greenbelt policy goals of urban growth containment and farmland preservation, the expected benefits from this new generation of greenbelts include providing ecosystem services, mitigating and adapting to climate change and developing green infrastructures (Natural England and Campaign to Protect Rural England, 2010). These multi-functional greenbelt policies are also expected to support urban regions' economic competitiveness and contribute to regional identity by promoting landscape attractiveness (Macdonald and Keil, 2012). In several cases, these new generation greenbelts have been upscaled to be more regional in scope, reflecting recent trends of metropolitanization of urban growth and regionalism, with expanding regions that see their settlement cores becoming increasingly interconnected (ibid.; Addie and Keil, 2015). With greenbelt policies addressing multiple purposes, contemporary environmental management becomes institutionally more complex-involving a network of government agencies, non-governmental organizations, and public-private partnerships (Kortelainen, 2010).

Particularly in the German case, greenbelt planning shows some significant differences from the UK cases. As the rise of regional parks since the early 1990s demonstrates, greenbelts in Germany are often designed as strategies to contain urban growth and protect greenspace at regional scales (Siedentop et al., 2016). These regional greenbelts have been developed to address the growing complexity of city-regions, as strong interregional competition increased development pressure on greenspaces with the municipal land-use planning system failing to reduce sprawl and greenspace loss (Gailing, 2007). Apart from often being at the regional scale, German greenbelt management is characterized by limited legal requirements or guidance from the national government (Siedentop et 
al., 2016). As both greenbelts and regional parks are not formally defined under national nature conservation or spatial planning laws, regional and municipal authorities have flexibility in their implementation resulting in heterogeneous planning practices (ibid.). In particular, regional parks are project-oriented landscape development strategies whose features include the multi-functionality of different land-uses as well as their strengthening of regional competitiveness and identity (Gailing, 2007). Prominent examples include the Emscher Landscape Park, the Regionalpark RheinMain and the Berlin-Bradenburg regional parks. In contrast to traditional greenbelt policies, these regional parks represent specific forms of greenspace governance, which are designed to complement formal spatial planning and nature conservation policies (ibid.). Strong cooperation is necessary for successful regional park development, as these regional greenbelts are designed as inter-authority initiatives involving collaboration between state, regional and municipal authorities, along with private and civil society stakeholders (ibid.). These greenbelts thus involve coordination across multiple policy domains, various jurisdictions and between policy levels. They challenge government-led forms of greenbelt planning and include collaborative arrangements with private and civil society stakeholders, which are increasingly involved in greenbelt management that was previously the primary purview of the state.

\subsection{INSTITUTIONAL COMPLEXITIES AND THE GOVERNANCE OF REGIONAL GREENBELTS}

Given the conditions of increasingly multi-purpose greenbelts involving arrangements between numerous stakeholders, we argue that applying a regional governance lens is most appropriate when studying German greenbelt development. Similar to broader regional development processes, it can be argued alongside Willi et al. $(2018,12)$ that the governance of regional greenbelts happens through "network-like coordination [...] processes and comprises vertical and horizontal coordination of state and non-state actors in a functional space." To understand the challenges involved in governing new generation greenbelts, it becomes necessary to analytically shift the focus away from hierarchical systems of state government to include more networked arrangements bringing an array of stakeholders into policy analysis (Stoker, 1998). Based on the observation that state responsibilities in greenbelt management have been partially redistributed to non-state actors who operate at different geographical scales and whose scope crosses jurisdictional borders, this indicates a re-scaling of decision-making to address regional problems (Brenner, 2003; Kortelainen, 2010). However, managing the interdependencies between the various institutions and stakeholders involved in new generation greenbelt management creates coordination challenges. 
The governance of regional greenbelts is significantly shaped by their institutional environments - an aspect that has hardly been addressed in current literature (exceptions with regards to German and UK cases include Röhring and Gailing, 2005 and Mace, 2018). Institutional environments shape the model of greenbelt planning used in that city or region, influencing greenbelt policy implementation (Han and Go, 2019). Behind all the stakeholders involved in greenbelt governance are institutions, which we define as the practices and rules that are situated within structures that are relatively resilient in the face of changing external circumstances (March and Olsen, 2011). Thus, institutions distribute power relations, enable, and constrain actors and create order (ibid.). What constitutes an institution varies across the disciplines, yet the focus in all institutional analyses is on the connection between institutions and actors' behaviour and exploring how institutions are established and change (Hall and Taylor, 1996). Institutions provide the structures necessary for governance, as institutional arrangements shape actors' interactions and influence the outcomes of those interactions (Hohn and Neuer, 2006). Within governance debates, institutions are seen as key elements of metropolitan governance, yet questions remain about which institutional arrangements are best to address regional problems (Galland and Harrison, 2020). Prominent institutional perspectives within the governance literature include the metropolitan reform model, the public choice school and new regionalism, which each advocating different approaches to governing city-regions (see Glass, 2018; Nelles, 2012). Once established, urban planning related institutions can become increasingly hard to change over time (Sorensen, 2015). Thus, as stakeholders see greenbelt policies sustained for years, they adjust their behaviours accordingly, particularly landowners within a greenbelt which have the assurance that development is unlikely to occur within these protected areas (Mace, 2018).

Through applying an institutional lens to greenbelt development, we identify three institutional dimensions impacting the effectiveness of regional greenbelt governance ${ }^{16}$. Horizontal coordination results from interdependencies between institutions at the same policy level-municipal, regional, or state. The number of policy fields affected through horizontal interactions complicates greenbelt management, which includes spatial planning, nature conservation and transportation and their associated stakeholders in the public and private sectors, along with civil society groups. Institutions are often created within siloed policy domains without considering their interdependencies with other policy fields, leading to conflicts affecting regional parks (Röhring and Gailing, 2005). At the same time, greenbelt governance is often strongly influenced by powerful private stakeholders such as developers, resulting in stakeholder self-interests impacting policy implementation (Cadieux et al., 2013).

16 For similar analytical categories see: Röhring and Gailing, 2005; Young et al., 2008; Young, 2002. 
Vertical coordination results from the interdependencies between institutions at different policy levels-municipal, regional, or state. A significant issue affecting regional greenspace governance is that the vertical institutional design of regional greenbelt policies requires cooperation between stakeholders at different policy levels. However, as greenbelt policies are usually set by a higher-level government and then implemented by a lower-level of government, coordination problems between these stakeholders can cause implementation issues (Carter-Whitney, 2010).

There is also a need for territorial coordination between institutions as regional greenspaces do not match boundaries of municipal or regional jurisdictions, but often cross jurisdictional borders, resulting in institutional "misfits" (Röhring and Gailing, 2005; Young, 2002). Thus, regional greenbelt management requires territorial coordination across multiple municipal and special purpose bodies' jurisdictions, which influences policy implementation. Greenbelt management can also be hindered by conflicts arising along boundaries between institutions and the interaction of stakeholders from multiple policy fields, which can have separate yet overlapping memberships. Each of these types of coordination is contested, involving entrenched power relations. Combining these three forms of institutional coordination allows for an analysis of the difficulties of greenbelt management as well as to examine the institutional problems associated with regional greenbelt governance, which will be discussed later in the article.

\subsection{THE GOVERNANCE OF THE FRANKFURT GREENBELT AND THE REGIONALPARK RHEINMAIN}

This section outlines how the Frankfurt greenbelt and Regionalpark RheinMain are embedded within the Frankfurt Rhine-Main region's complex institutional environment. The greenbelt is located within the City of Frankfurt, which has approximately 740,000 residents and is the largest among the 75 municipalities forming of the Greater Frankfurt region (Regionalverband, 2018). As a politically defined territory of the Regional Authority Frankfurt RhineMain, the Greater Frankfurt region has 2.34 million people, including a network of cities (Frankfurt and Offenbach), smaller towns and the government centres of Wiesbaden, Mainz, and Darmstadt (ibid.). The City of Frankfurt constitutes the biggest urban node in the Frankfurt Rhine-Main Metropolitan region-established to strengthen the region's international competitiveness-which has 5.7 million inhabitants and 468 municipalities (Diller, 2016; Regionalverband, 2018) (Figure 4.1). In recent years, the Greater Frankfurt region has experienced strong demographic growth and is expected to grow by 191,000 inhabitants by 2030 (ibid.). Frankfurt has significant functional 
interdependencies with its surrounding region through commuter flows, a regional division of labour and suburbanisation of service industries. Other than the Frankfurt greenbelt and the Regionalpark RheinMain, the Frankfurt Rhine-Main region has a greenspace network including the Offenbach greenbelt, the Nature Park Hochtaunus, and the Hessische Ried agricultural area.

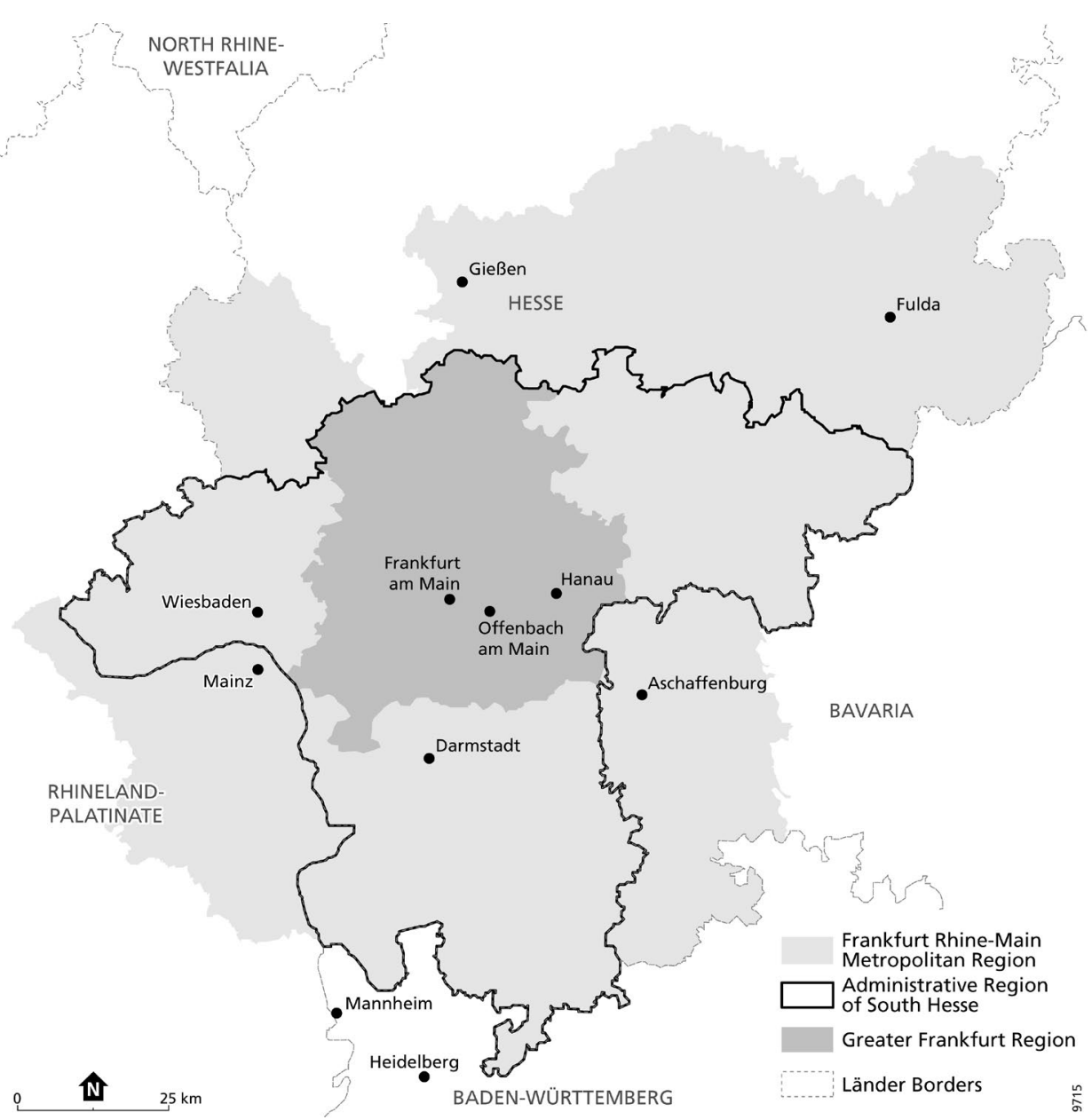

Figure 4.1: Frankfurt Rhine-Main Metropolitan Region and the Greater Frankfurt Region

Source: Regionalverband, 2018

The governance of regional greenspaces in the Frankfurt Rhine-Main region is strongly shaped by regional institutional reform and organized through inter-municipal planning. Already in 1975, the state government forced 43 municipalities in the Greater Frankfurt Area to collaborate within the Greater Frankfurt Association (Umlandverband Frankfurt). 
Faced with the increasing embeddedness of Frankfurt within a metropolitanized region, multiple municipal planning tasks were upscaled to the level of the Greater Frankfurt Area. The Umlandverband Frankfurt was the planning association responsible for the creation and initial management of the Regionalpark RheinMain in the early 1990s, including 43 municipalities and 1.5 million residents until its dissolution in 2001 (Freund, 2003). In 2001, the state government created an enlarged Greater Frankfurt Region with 75 municipalities. A new planning association was installed, the Planungsverband Ballungsraum Frankfurt/ RheinMain, which briefly managed the Regionalpark RheinMain in the early 2000s. Due to the Umlandverband's alleged inefficiencies, the responsibility for several public services that were previously concentrated in the Umlandverband were either "re-municipalized" or delegated to a plethora of voluntary inter-municipal agencies and special purpose organizations (Monstadt et al., 2012). This also applies to the development of the regional greenbelt whose management is not overseen by a government administration but has since 2005 been delegated to a special purpose organization, the Regionalpark Ballungsraum RheinMain $\mathrm{GmbH}$. Other responsibilities delegated to such single purpose organizations include the provision of water, waste and transportation services, and promoting business development activities, which operate within task-specific geographies and often only partly overlapping jurisdictions (ibid; Hoyler et al., 2006). In 2011, the Planungsverband was disbanded and a new regional institution was created, known as the Regional Authority (Regionalverband FrankfurtRheinMain). The Regional Authority prepared a regionalised land-use plan and landscape plan for its 75-member municipalities and 2.34 million residents in the Greater Frankfurt region.

While the city of Frankfurt held the responsibility for land-use planning within its jurisdiction when the Frankfurt greenbelt was designed, the Regionalpark RheinMain is influenced by various levels of spatial planning policies by its member municipalities, the Regional Authority and the state government. The Regional Authority developed a regionalised land-use plan (regionaler Flächennutzungsplan) that came into effect in 2011, replacing previous municipal plans in its member municipalities. The result is that these cities need to negotiate their interests at the regional scale. Drawing on the German "central place system" principle in spatial planning, the regionalised land-use plan prioritizes development within existing urban areas and along transportation corridors, securing greenspaces and expanding the Regionalpark RheinMain (Regionalverband, 2010; Schmidt et al., 2018). Organized by a "counterflow principle" in which the federal, state and municipal levels influence each other's plans, the State development plan for Hesse (Landesentwicklungsplan) and the regional plan for South Hesse set general objectives, which are detailed in the regionalised land-use plan (Schmidt, 2009). Both the regionalised land-use plan and spatial development plan by the state government include policies protecting the Regionalpark RheinMain and Frankfurt greenbelt. 
This greenbelt and Regionalpark are strongly shaped by nature conservation and landscape planning policies. The Federal Nature Conservation Act is the main source of German nature conservation law. Landscape planning runs parallel to the spatial planning system at the Länder, regional and municipal levels and landscape plans only become binding when they are integrated into spatial planning policies (Federal Agency for Nature Conservation, 2008). An important principle of German nature conservation law is that greenspace destruction through development must be compensated for by the person or organization responsible for that project, in case it cannot be avoided (Rautenstrauch, 2015). Both the Frankfurt greenbelt and the Regionalpark RheinMain have benefited from these compensation policies, particularly because of the airport extension, further securing their protection.

\subsection{FROM THE FRANKFURT GREENBELT TO THE REGIONALPARK RHEINMAIN}

The histories of the Frankfurt greenbelt and Regionalpark RheinMain reflect regionalisation processes within the Frankfurt Rhine-Main region over the past three decades. The Frankfurt greenbelt is an 8000-hectare protected greenspace forming a 70-kilometre belt around the city. Apart from endangered species protection, the conservation of cultural landscapes and its function as a fresh air corridor, there is a focus on recreation within the greenbelt. Influenced by planner Ernst May's work, the greenbelt has an extended history including the forest to the south of Frankfurt and two previous smaller greenbelts (Wei, 2017). As one of the most important environmental policies of a newly elected coalition of Frankfurt's Social Democrats and Green Party in 1989, the current greenbelt was a product of an innovative planning process overseen by both the office of Tom Koenigs (the Head of the Environment Department) and the GreenBelt Project office, and approved by city council (Ronneberger and Keil, 1993). In 1991, the Frankfurt City parliament unanimously passed the "GreenBelt constitution." A key principle of this legally non-binding agreement was to refrain from development and, if not feasible, to compensate for land removed from the greenbelt by adding land of the same size and quality to the greenbelt elsewhere (Husung and Lieser, 1996).

Following a period of management by the GreenBelt GmbH, the GreenBelt Group-a collaboration of 13 staff members within multiple city departments-has been responsible for greenbelt development since 1997. It has an annual budget of $€ 200$ thousand for investments in new construction or maintenance and shares $€ 150$ thousand per year with other departments for planning programs (Interview 1 ). The greenbelt is strongly protected under spatial planning and nature conservation regulations. Through the designation as 
an area under protection by the Federal Nature Conservation Act, the greenbelt and areas in neighbouring municipalities enjoy far-reaching building restrictions that are adopted in municipal, regional, and state spatial plans. Making land-use changes to the greenbelt is thus difficult as this requires amendments at numerous policy levels given that greenbelt policies are included in the regionalised land-use plan and the state development plan for Hesse (Interview 2). In 2015, the "Spokes and Rays" (Speichen und Strahlen) Plan released an updated greenbelt concept making stronger connections between the Frankfurt greenbelt and regional greenspaces, although ultimately, this plan was not adopted (Stadt Frankfurt am Main, 2015). Similar greenspace developments took place in Offenbach, which developed its green ring (Grünring) before Frankfurt's greenbelt. Enclosing the city's core and connecting greenspaces along the Main river, the green ring was initially protected in Offenbach's 1984 land-use plan, later included in the Regionalpark RheinMain in 2000 and secured in the Regional Authority's landscape plan (Stadt Offenbach, 2017). Despite several regional reforms (see above), greenspace policies in the Greater Frankfurt region have mostly adhered to traditional municipal or regional jurisdictions. However, regional policymakers have long recognized its greenbelt's regional connections, with Frankfurt's or Offenbach's localized greenbelt policies no longer reflecting the highly interconnected regional context within which these greenspaces are situated. The establishment of the Regionalpark RheinMain can thus be seen as a response to the increasingly metropolitanized region and as an ambition to upscale localized initiatives to a (more functional) regional scale and to integrate them into a regionalised greenspace network.

Similar to other German regions, the Greater Frankfurt greenbelt is called a Regionalpark. The Regionalpark RheinMain stretches across the metropolitan region as a green corridor network reaching to the Nature Park Hochtaunus. Comparable to traditional greenbelt policies such as those in the UK, the Regionalpark was designed to protect regional greenspaces, provide recreational spaces (Dettmar, 2012) and to control the direction of development (Interview 3). The Regionalpark also includes contemporary greenbelt policy goals such as contributing to economic development and promoting regional identity. However, since the Regionalpark is comprised of a regional greenspace network, it differs from one of the main purposes of traditional greenbelts, as its policies were not intended to create a boundary around the growth of a city. Approved in 1994 by the Umlandverband and following a transitional period of management by the Planungsverband, a regional greenbelt agency (Regionalpark Ballungsraum RheinMain GmbH) was founded in 2005 (Rautenstrauch, 2015). The Regionalpark is coordinated by this agency, which was planned as a public-private partnership with its implementation delegated to six inter-municipal implementation bodies that are responsible for developing sub-projects. The greenbelt agency is supported by 15 shareholders, including 123 municipalities, the Regional Authority, and the state government, which each pay an annual fee to the company (Dettmar, 2012). 
The financial model of the greenbelt agency is based on an annual contribution of $€ 75$ thousand from each of its shareholders, the Regional Authority, and the state government, amounting to $€ 1.25$ million per year (Interview 4). The remaining budget comes from Fraport AG's contribution-the operator of Frankfurt's airport-and since 1997 the only private sponsor for the park (Dettmar, 2012). In 1997, Flughafen AG (now known as Fraport AG) established a voluntary fund for nature conservation projects, giving the Regionalpark top priority (Rautenstrauch, 2015). Fraport has provided approximately $€ 800$ thousand per year to the greenbelt agency and as of 2016, €17 million from this fund has gone to the park (Dettmar, 2012; Krug, 2016). However, the Fraport AG has announced its intention to reduce its contribution to $€ 400$ thousand per year in 2020 and to fully withdraw from financing the Regionalpark in 2021 (Interview 5).

The size of the Regionalpark has increased significantly since its introduction. Starting with 3 municipalities, it grew to 129 municipalities by 2012 (Dettmar, 2012) and is currently 4463 square kilometres. As the greenbelt agency has no planning authority over its territory, its staff must consult with the Regional Authority and the Regional Planning Authority for South Hesse to ensure that its greenspaces are integrated into spatial planning policies. However, despite the strong German spatial planning system, the Regionalpark RheinMain is only weakly protected. Its only formal protection is under the land-use category of "regional green corridors" (Grünzüge) in the regional plan for South Hesse and the regionalised land-use plan. Also, several areas within the Regionalpark are protected by different types of nature conservation areas with varying levels of protection. The Regionalpark's establishment and development was strongly supported by key individuals such as Lorenz Rautenstrauch. These individuals' commitment over the past three decades and the creation of informal networks of public, private, and civil society stakeholders supporting park projects contributes to the fact that the Regionalpark still exists today.

\subsection{THE COMPLEXITIES OF PLANNING A GREENBELT FOR THE FRANKFURT RHINE-MAIN REGION}

In this section, we explore how institutional coordination at various policy levels and between public and private actors across numerous municipalities in the Frankfurt Rhine-Main region impact the Regionalpark's implementation. Through a discussion of institutional coordination at different policy levels, between several policy fields, and across administrative jurisdictions related to the Regionalpark, we analyse the challenges involved in planning a regional greenbelt for Frankfurt Rhine-Main. 


\subsubsection{Horizontal coordination: How interdependencies between policy fields influences Regionalpark implementation}

The Regionalpark RheinMain's management is complicated by connections to numerous policy fields including nature conservation, economic growth and their related stakeholders in the public, private and civil society sectors. First, the Regionalpark is displayed prominently within nature conservation policies. One of the regionalised landscape plans' main targets in securing greenspaces is through the park, giving priority to nature compensation measures within the Regionalpark and the Frankfurt and Offenbach greenbelts (Planungsverband, 2001). By integrating the Regionalpark into the regionalised landscape and land-use plans, planners are required to incorporate these objectives into local policies, reinforcing park protection (Gailing, 2007). However, the region's landscape plans are outdated and do not reflect the current regional conditions, as the Regional Authority's most recent landscape plan is from 2001.

Also, the Regionalpark is promoted beyond nature conservation policies as an important mechanism contributing to economic development strategies. The Frankfurt and Offenbach greenbelts and Regionalpark promote regional attractiveness, which is becoming increasingly important to regional competitiveness, particularly considering Brexit and the resulting ambitions by municipal and Länder governments to incentivize businesses to relocate from London to Frankfurt. The regionalised land-use plan states that so-called "soft location factors" such as greenspaces contribute to regional competitiveness and that the Regionalpark is a "significant soft location factor that improves the image of the region" (Regionalverband, 2010, 89) ${ }^{17}$. The Strategic Vision “Frankfurt/Rhein-Main 2020" also promotes landscapes such as the Regionalpark and supports greenspace protection (Planungsverband and Regierungspräsidium, 2005). Frankfurt's ability to attract investment rests on the region's capacity to provide a range of supportive services, while the region's economic competitiveness and inter-municipal competition is linked to its polycentric structure (Hoyler et al., 2006). In practice though, power asymmetries between Frankfurt and its neighbouring municipalities often challenge the institutionalization of regionalism within the Greater Frankfurt region (Keil, 2011).

At the same time, the Regionalpark's implementation is vulnerable through its financial dependency upon the airport operator Fraport. It has recently been decided that Fraport's funding to the park will end in 2021 (Interview 5). In response, the park's shareholders have pledged to increase their annual payments in the next few years to compensate for Fraport's funding withdrawal (Interview 5). However, no long-term official decisions have been made as of the time of writing. This financial uncertainty currently affecting

17 All translations are done by the authors. 
the Regionalpark reflects a larger concern within greenbelt planning. While there is an increasing reliance upon public-private-partnerships in environmental management, the Regionalpark's financial structure highlights the weakness of this governance model, given that greenbelt policy implementation can be threatened by shifting funders' priorities.

In addition to the complexities created by horizontal connections to nature conservation and economic policies, the Regionalpark's effective implementation is vulnerable to the region's powerful growth politics. Regional greenspaces are under increasing pressure due to the regional housing shortage. Despite strong spatial planning policies, the inter-municipal land-use planning system has failed to contain suburbanisation, and development patterns are influenced by local growth coalitions and municipal competition for taxes, resulting in a spatially fragmented suburban landscape (Monstadt and Meilinger, 2020). This is particularly a problem since the greenbelt agency has no planning authority to confine regional growth patterns. In the past 25 years, there have been few cases of Regionalpark land being lost to development (Interview 4). Regional politicians have generally adhered to these policies, seeing the park as a regional asset (Interviews 4 and 6). However, long-held views on the firm protection of regional greenspaces are beginning to shift, as these natural areas may no longer be considered "untouchable" to future development (Interview 7). Thus, the strong dynamics of regional growth politics, the Regionalpark's weak institutional design and shifting opinions on greenspace protection combine to make park's policies vulnerable to local self-interests.

In summary, as the Regionalpark policies intersect with numerous policy domains, this increases the number of stakeholders involved in park management. However, this process can create conflicting demands between policy goals, with some stakeholders disproportionately influencing Regionalpark implementation.

\subsubsection{Vertical coordination: Collaboration challenges between policy levels results in localized greenbelt initiatives}

To effectively manage a regional greenbelt, coordination between stakeholders is needed at multiple policy levels including municipal, regional, and state governments. However, analysis of the Frankfurt Rhine-Main's governance arrangements reveals significant tensions in vertical interactions between institutions at these different policy levels. These coordination problems challenge the ability to have an effective regional greenbelt, resulting in the delegation of greenbelt planning to the local level. The strong connections between multiple policy fields at different policy levels that promote nature conservation and compact development, at first glance, appear to promote favourable conditions within the Frankfurt Rhine-Main region for a regional greenbelt to emerge. However, further investigation shows that vertical coordination issues between state, regional and local 
authorities create challenges for greenbelt implementation. Nonetheless, on the positive side, the German spatial planning system restrains municipal growth, as development approvals require either respective designations as building areas in land-use plans or changes of such plans, which require approval by upper-tier planning authorities. Moreover, the Federal Nature Conservation Act provides several instruments to protect greenspaces including a multi-tier system of landscape planning at the Länder, regional and municipal level, a system of protected areas, and compensation schemes for the destruction of nature. The Frankfurt and Offenbach greenbelts, and Regionalpark RheinMain are protected by a system of protected areas and their development is promoted by the landscape plan at the inter-municipal level.

However, the agency managing the Regionalpark has only limited authority over its member municipalities to effectively implement a regional greenbelt. On the one hand, regional greenbelt management is coordinated by a special purpose body with limited planning authority, staff and resources, and these resources became further strained by increasing membership (Dettmar, 2012). The main institutional resources and the authority to designate protected areas, to confine urban growth and to develop greenspaces are horizontally and vertically distributed between nature conservation and spatial planning authorities at different levels. On the other hand, Regionalpark implementation has been delegated to six inter-municipal implementation bodies, giving municipalities more freedom in developing their own sub-projects. Given its weak institutionalization, the greenbelt agency's mandate shifted to tourism promotion since 2008 from its original focus on protection from development (Rautenstrauch, 2015).

A weakness in the vertical institutional design of regional greenbelt management is that the state government (and its spatial planning authorities at the Länder level and level of South Hesse) has no active role in greenbelt development. However, the Regional Authority has greater involvement in Regionalpark planning as its staff collaborates with the greenbelt agency on relevant projects and the Regionalpark is integrated in the regionalised land-use and landscape plans (Interview 6). Apart from this collaboration with spatial planning and nature conservation authorities, the greenbelt agency has no power to enforce compliance to its goals, making it vulnerable to local self-interests. However, there appears to be no desire by the state government or the Regional Authority to give more powers or resources to the greenbelt agency, and municipalities would likely resent further development restrictions (Interview 5 and 6). Because of these factors, the Regionalpark RheinMain faces considerable institutional challenges in effectively fulfilling a mandate in regional growth and greenspace management. 
With these concerns in mind, the Regional Authority seems to be the appropriate organization to manage a regional greenbelt, given its mandate in metropolitan development, its planning authority for the Greater Frankfurt region and its policies on nature conservation and smart growth as formulated in its regionalised land-use and landscape plans. However, the Regional Authority's capacity for effective growth management is challenged by its embeddedness within a complex and fragmented institutional environment including state, municipal and special purpose organizations. The Regional Authority as an inter-municipal body established by the state government needs to coordinate not only with its 75-member municipalities, but also with the region of South Hesse and the state government, each of which have their own development interests (Monstadt and Meilinger, 2020). Thus, while the Regional Authority has the statutory powers to define land-use and has more resources available than a special purpose body does, it also faces challenges that would impact regional greenbelt management.

Due to these institutional constraints that influence the effectiveness of regional greenbelt implementation, key authority for greenbelt planning is de facto with the municipalities. Here, particularly the Frankfurt greenbelt has been successful in that almost no land has been lost to development since its introduction (Wei, 2017). However, given the local scale of the Frankfurt greenbelt, it cannot effectively manage regional growth, nor was it designed to address regional concerns. Thus, if regional authorities want to achieve the benefits a regional greenbelt could offer, localized initiatives such as the Frankfurt greenbelt cannot realize those goals. The discussion about horizontal and vertical coordination reveals the challenges of implementing a regional greenbelt within the Frankfurt Rhine-Main region. Ultimately, greenbelt planning must occur at the regional scale and must be properly institutionalized with strong regulatory protection.

\subsubsection{Territorial coordination: Coordination problems across jurisdictions results in the downscaling of activities to the local level}

Frankfurt Rhine-Main provides a perfect case to study a common regional governance problem: the misalignment of administrative and functional spaces (Nelles, 2012). These institutional misfits create coordination challenges with conflicts arising along these overlapping boundaries. The Regionalpark RheinMain and its institutional arrangements contains misfits, given that it is situated within various layers of regional governance structures including multiple municipalities, the Regional Authority, and the regional planning authority of South Hesse-none of which match the boundaries of the park (Figure 4.2). For example, when the Regionalpark was created, two cities-Darmstadt and Mainz-were excluded. Neither city was part of the Umlandverband, which could only finance projects within its own boundaries (Interview 4). However, the city of Wiesbaden is located within the Regionalpark, yet it is not within the jurisdiction of the Regional 
Authority (see Figure 4.2) (Interview 5). An additional layer of territorial complexity is that the Regionalpark is part of a larger regional greenspace network including the Frankfurt and Offenbach greenbelts, a national park, a biosphere reserve, and nature parks, each having different and partially overlapping territorialities.

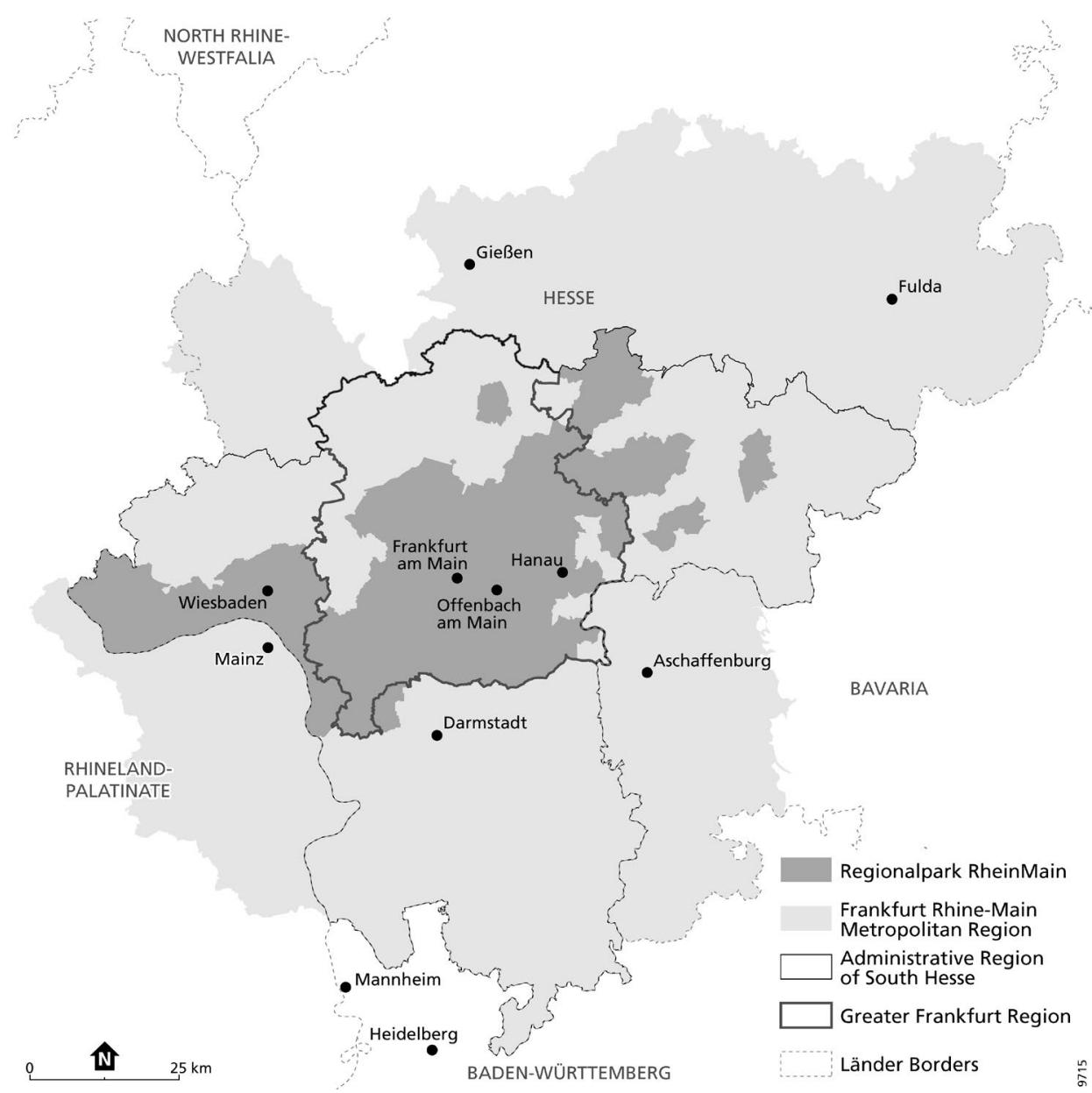

Figure 4.2: The Fragmented Regional Governance Landscape in Frankfurt Rhine-Main

Source: Regionalverband, 2018; Regionalpark RheinMain GmbH

Navigating these multi-layered territorialities presents significant governance challenges for the greenbelt agency, as it must coordinate with municipal, regional, and state agencies. For example, coordination is complex when the greenbelt agency tries to promote its activities, resulting in staff contacting eight tourism organizations that overlap the park's area. Thus, collaborating with many organizations challenges the delivery of a consistent 
message to the public (Interview 5). Analysing the Regionalpark reveals a regional governance landscape within the Greater Frankfurt region that has multiple administrative jurisdictions overlapping with geographies of special purpose bodies. While the Greater Frankfurt region has undergone waves of governance reforms, the territorial scope of its planning associations has only partially reflected functional relationships. Moreover, special purpose organizations' jurisdictions often do not coincide with the planning association's borders, reinforcing inter-municipal competition (Freund, 2003; Nelles, 2012).

Because of these institutional misfits, a coping mechanism has been to downscale activities to the local level. Park project development has been delegated to the municipal scale, as inter-municipal implementation bodies are responsible for delivering these activities. At the local level, governance processes are facilitated by providing stakeholder participation opportunities for farmers, park users and businesses, particularly through the park's popular programs (Krause, 2014). Also organized at this scale are civil society initiatives for nature conservation, which are historically rooted in local engagement activities. Examples are BUND - the Federation for Environment and Nature Conservation (Bund für Umwelt- und Naturschutz e.V.), NABU-the German Association for Nature Conservation (Naturschutzbund Deutschland e.V.) and initiatives for the protection of the Taunus, which are either organized at the scale of neighbourhoods, cities, municipal districts (Kreise) or the state level of Hesse. While they have been effective in lobbying for the Frankfurt and Offenbach greenbelt or the Nature Park Hochtaunus, their engagement with regional issues have been mostly limited to protests against the airport extension. However, regional environmental issues such as regional greenspace conservation overreach local groups' jurisdictions, thus regional greenbelt initiatives are largely absent.

Also missing is public awareness about the Regionalpark, resulting in part due to this greenspace's vast territorial scope. Indeed, the increasing size of the park and member municipalities' diverging interests influenced the greenbelt agency's decision to concentrate its resources on the area of the park within the agglomeration to increase public awareness (Interview 6). This lack of recognition reflects the Greater Frankfurt region, which "remains internally fragmented both politically and administratively and lacks a clear regional identity" (Hoyler et al., 2006, 133). To conclude, there will never be a perfect fit between administrative and functional boundaries, thus numerous mechanisms are needed to overcome these institutional mismatches. However, the Frankfurt Rhine-Main region's complex and overlapping institutional structures present significant challenges to finding effective strategies to overcoming institutional misfits, resulting in the downscaling of greenbelt activities to the local scale to address issues in a simpler institutional context. 


\subsection{CONCLUSION}

This article examined the institutional complexities of upscaling a greenbelt to the regional scale in the Frankfurt Rhine-Main region, shaped by horizontal, vertical, and territorial coordination problems. By exploring these three dimensions, we analysed the institutional challenges of regional greenbelt governance, which showed the diverse policy fields affecting greenbelt implementation, the interdependencies between institutions at different policy levels and territorial misfits. Embedded at the interface of multiple policy domains, the Regionalpark's implementation is affected by inter-policy conflicts. While nature conservation authorities and environmental groups promote greenspace protection, powerful economic development policies and their related private stakeholders lobby against land-use restrictions. Coordination problems between stakeholders at different policy levels and across municipal and special purpose bodies' territorial jurisdictions create significant challenges for Regionalpark management, resulting in localized initiatives. Also, several factors negatively influence its implementation including weak policy protection and the greenbelt agency's lack of spatial planning authority, low staffing levels, fiscal uncertainty, and its embeddedness within a fragmented institutional environment. In a region with a history of land-use conflicts affecting greenspaces (e.g. airport runway expansions), the greenbelt agency made a decision to focus its activities on an uncontroversial tourism mandate and moved away from its initial focus of the park serving as a buffer from urban sprawl, thus trying to avoid conflicts with other organizations. Therefore, we conclude that the Regionalpark RheinMain's agency is not properly institutionalized to manage an effective regional greenbelt, resulting in a delegation of greenbelt planning to the municipal level. Progressive for their time, the Frankfurt and Offenbach greenbelts were significant steps in urban environmental protection. However, as both cities are now embedded within a region experiencing extensive growth pressures, more ambitious efforts are needed to effectively manage regional greenbelts.

When assessing the effectiveness of the Regionalpark RheinMain to serve as a regional greenbelt, it is important to reflect upon what its original purposes were, which included protecting greenspaces from development and providing recreational opportunities (Rautenstrauch, 2015). While the multi-layered spatial planning system has been moderately effective in directing development away from greenspaces and minimal land within the Regionalpark has been lost to urban growth (Interview 4), we find that it is unlikely that the park can fulfil larger ambitions as a regional greenbelt.

Traditionally, greenbelt policies were designed as an urban growth buffer through restrictive land-use planning instruments that provide long-term protection against urban development. In contrast, regional park policies reflect more flexible institutional 
arrangements, providing municipalities much leeway in park project implementation. As Frankfurt Rhine-Main is a polycentric region experiencing substantial peripheral growth pressures, the spatial shape of a traditional urban greenbelt forming a ring of greenspace separating a central city from the surrounding countryside is no longer suitable. Instead, similar to other international greenbelts such as that in Milan, a regional greenspace network is more appropriate for these current regional conditions. However, regional greenbelts require adequate institutional arrangements to contain growth and protect greenspaces at a regional scale.

While Frankfurt Rhine-Main would benefit from a regional greenbelt, overly complex arrangements in the governance of the Regionalpark make this goal almost impossible to achieve. Thus, our research indicates that the Regionalpark agency's institutional design as a special purpose body does not enable effective regional greenbelt implementation. Accordingly, strategies could be applied to improve the existing situation. First, Regionalpark policies need to be monitored and evaluated to assess their effectiveness in meeting their policy goals and then updated regularly based on this data. Also, the greenbelt agency could capitalize on the park's potential to provide eco-system services and create educational programs promoting these features. Finally, the greenbelt agency could build upon their successful relationships with local stakeholders to diversify their collaborations beyond their tourism mandate. Thus, the greenbelt agency could form strategic partnerships with nature conservation authorities, environmental groups, and agriculture and forestry related organizations, which would allow this agency to pool resources together with relevant stakeholders to create larger programs supporting the Regionalpark.

However, these are only incremental strategies aimed at improving the existing situation, and institutional reforms are required to develop the Regionalpark into an effective greenbelt that confines urban and suburban growth. Regional greenbelt planning should be re-integrated into the Regional Authority (Regionalverband FrankfurtRheinMain), as they have the authority for spatial and landscape planning in Greater Frankfurt and can lead strategically important processes for the metropolitan region such as facilitating cooperation amongst regional companies. The Regionalpark has a well-established history with the Regional Authority, as it was previously managed by its predecessor (the Planungsverband), and staff from the greenbelt agency and Regional Authority already work together on park planning. If the Regional Authority were to be given more authority and resources to effectively manage the Regionalpark (e.g. by integrating the greenbelt agency as its own department within the Regional Authority), the park could reinforce the growth management goals of the regionalised land-use plan and this reform could partially reduce regional institutional fragmentation. Although not having the formal responsibility for greenbelt development, the Regional Authority currently complements the soft approach of the regional greenbelt 
agency by its formal planning instruments that are used to protect open spaces from urban sprawl. These include the designation of nature conservation areas or the use of financial compensation schemes for the destruction of greenspaces through nature conservation policies or the designation of Priority and Reserve Areas (Vorrang- und Vorbehaltsgebiete) for agriculture, nature and landscape and green corridors in regional plans. Hereby, it would be more efficient to concentrate key responsibilities for the Regionalpark with the Regional Authority, as it could synergistically combine hard and soft planning approaches in greenbelt governance. However, regional greenbelt development cannot be effectively sustained by the Regional Authority alone without the support of civil society initiatives. The localized scope of nature conservation groups in the Frankfurt Rhine-Main region and their limited engagement for regional issues are thus important challenges to overcome. Regional collaboration of these localized environmental groups is equally important to effectively support regional greenbelt implementation.

The Frankfurt case provides insights for regional governance debates related to greenbelts and institutions. Within the regional governance literature, there is a greater focus on more flexible institutional arrangements including soft spaces of governance and the increased use of special purpose agencies to provide public services (Lucas, 2016; Zimmerbauer and Paasi, 2019). Urban regions have thus become increasingly institutionally fragmented with numerous authorities at multiple policy levels, which creates governance problems (Storper, 2014). However, our research indicates that these flexible and collaborative arrangements can also entail "governance failures" and that more effective institutional frameworks are required to ensure regional greenbelt management (Jessop, 2000). Special purpose agencies often have limited authority and institutional capacity, can contribute to regional fragmentation, and may not be situated at the appropriate territorial scale to properly undertake the responsibilities assigned to them. However, successful greenbelt management-understood as confining urban and suburban growth and protecting greenspaces - needs an effective allocation and re-allocation of land-use rights against the resistance of municipalities and developers. This redistribution of land-use rights that comes with urban growth containment and greenspace protection, though, requires strong planning authority and thus cannot be undertaken by special purpose bodies. Instead, we argue that new generation greenbelt management requires government organizations with sufficient regulatory powers and resources to effectively implement greenbelt policy goals. To conclude, the Regionalpark RheinMain and the Frankfurt and Offenbach greenbelts are important environmental assets to the Frankfurt Rhine-Main region. However, the Regionalpark RheinMain is now at a crossroads due to increasing regional development pressures. While it is more important than ever to strengthen the Regionalpark's future protection, it remains uncertain if that is possible given the significant institutional constraints within which it is situated in the Frankfurt Rhine-Main region. 


\subsection{REFERENCES}

Addie, J. P. D., \& Keil, R. (2015). Real existing regionalism: The region between talk, territory and technology. International Journal of Urban and Regional Research, 39(2), 407-417.

Amati, M. (Ed.). (2008). Urban green belts in the twenty-first century. Hampshire, England: Ashgate. Brenner, N. (2003). Metropolitan institutional reform and the rescaling of state space in contemporary Western Europe. European Urban and Regional Studies, 10(4), 297-324.

Cadieux, K. V., Taylor, L. E., \& Bunce, M. F. (2013). Landscape ideology in the Greater Golden Horseshoe greenbelt plan: Negotiating material landscapes and abstract ideals in the city's countryside. Journal of Rural Studies, 32, 307-319.

Carter-Whitney, M. (2010). Ontario's greenbelt in an international context. Friends of the Greenbelt Foundation. Retrieved from https://www.greenbelt.ca/ontario_s_greenbelt_in_an_ international_context2010

Dettmar, J. (2012). Weiterentwicklung des regionalparks Rheinmain. In Monstadt, J., Schönig, B., Zimmermann, K., \& Robischon, T. (Eds.). Die diskutierte region: Probleme und planungsansätze der metropolregion Rhein-Main. (pp. 231-254). Frankfurt am Main, Germany: Campus Verlag.

Diller, C. (2016). The development of metropolitan regions in Germany in light of the restructuring of the German states: Two temporally overlapping discourses. European Planning Studies, 24(12), 2154-2174.

Federal Agency for Nature Conservation. (2008). Landscape planning. The basis for sustainable landscape development. Retrieved from https://www.bfn.de/fileadmin/MDB/documents/ themen/landschaftsplanung/landscape_planning_basis.pdf

Freund, B. (2003). The Frankfurt Rhine-Main region. In Salet, W. G., Thornley, A., \& Kreukels, A. (Eds.). Metropolitan governance and spatial planning: Comparative case studies of European city-regions. (pp.125-144). London, England: Spon.

Gailing, L. (2007). Regional parks: Development strategies and intermunicipal cooperation for the urban landscape. German Journal of Urban Studies, 46(1).

Galland, D. and Harrison, J. (2020). Conceptualising metropolitan regions: How institutions, policies, spatial imaginaries and planning are influencing metropolitan development. In Zimmermann, K., Galland, D. and Harrison, J. (Eds.). Metropolitan regions, planning and governance. (pp. 1-24). Cham, Switzerland: Springer.

Glass, M. R. (2018). Navigating the regionalism-public choice divide in regional studies. Regional Studies, 52(8), 1150-1161.

Hall, P. A., \& Taylor, R. C. (1996). Political science and the three new institutionalisms. Political Studies, 44(5), 936-957.

Han, A. T., \& Go, M. H. (2019). Explaining the national variation of land use: A cross-national analysis of greenbelt policy in five countries. Land Use Policy, 81, 644-656.

Hohn, U., \& Neuer, B. (2006). New urban governance: Institutional change and consequences for urban development. European Planning Studies, 14(3), 291-298.

Hoyler, M., Freytag, T., \& Mager, C. (2006). Advantageous fragmentation? Reimagining metropolitan governance and spatial planning in Rhine-Main. Built Environment, 32(2), 124-136.

Husung, S. and Lieser, P. (1996). GreenBelt Frankfurt. In Keil, R., Bell, D. and Wekerle, G. (Eds.). Local places in the age of the global city. (pp. 211-222). Montreal, QC: Black Rose Books.

Jessop, B. (2000). The dynamics of partnership and governance failure. In Stoker, G. (Ed.), The new politics of British local governance, (pp. 11-32). Basingstoke: Macmillan. 
Keil, R. (2011). The global city comes home: Internalised globalisation in Frankfurt Rhine-Main. Urban Studies, 48(12), 2495-2517.

Kortelainen, J. (2010). The European green belt: Generating environmental governance-reshaping border areas. Quaestiones Geographicae, 29(4), 27-40.

Krause, R. (2014). Placemaking in the RhineMain regionalpark. (Master's thesis, Karlskrona, Sweden, Blekinge Institute of Technology). Retrieved from http://www.diva-portal.se/smash/get/ diva2:832027/FULLTEXT01.pdf

Krug, M. (December 27, 2016). "Fraport AG stockt umweltfonds auf fünf millionen euro auf." HessenDepesche-Wirtschaft. Retrieved from https://www.hessen-depesche.de/wirtschaft/fraport-agstockt-umweltfonds-auf-f\%C3\%BCnf-millionen-euro-auf.html

Lucas, J. (2016). Fields of authority: Special purpose governance in Ontario, 1815-2015. Toronto, ON: University of Toronto Press.

Macdonald, S., \& Keil, R. (2012). The Ontario greenbelt: Shifting the scales of the sustainability fix? The Professional Geographer, 64(1), 125-145.

Mace, A. (2018). The metropolitan green belt, changing an institution. Progress in Planning, 121, $1-28$.

March, J. G., \& Olsen, J. P. (2011). Elaborating the "new institutionalism". In Goodin, R. (Ed.). The Oxford handbook of political science. (pp. 159-175). Oxford, England: Oxford University Press.

Monstadt, J. and Meilinger, V. (2020). Governing suburbia through regionalized land-use planning? Experiences from the Greater Frankfurt region. Land Use Policy. 91.

Monstadt, J., Zimmermann, K., Robischon, T. \& Schönig, B. (2012). Die diskutierte region. Probleme und planungsansätze der metropolregion Rhein-Main. Frankfurt am Main, Germany: CampusVerlag.

Natural England and the Campaign to Protect Rural England (2010). Green belts: A greener future. Retrieved from https://www.cpre.org.uk/resources/housing-and-planning/green-belts/ item/1956-green-belts-a-greener-future

Nelles, J. (2012). Comparative metropolitan policy: Governing beyond local boundaries in the imagined metropolis. London, England: Routledge.

Planungsverband Ballungsraum Frankfurt/Rhein Main and Regierungsprasidium Darmstadt. (2005). Frankfurt/Rhein-Main 2020- the European metropolitan region. Strategic vision for the regional land use plan and for the regionalplan Sudhessen. Frankfurt, Darmstadt.

Planungsverband Frankfurt Region RheinMain. (2001). Landschaftsplan UVF. Aufbau, ziele, umsetzung. Retrieved from https://www.region-frankfurt.de/media/custom/1136_3_1.PDF

Rautenstrauch, L. (2015). Regionalpark RheinMain- Die geschichte einer verführung. Regionalpark RheinMain Ballungsraum GmbH. Frankfurt am Main, Germany: Societaets Verlag.

Regionalverband $=$ Regional Authority FrankfurtRhineMain. (2018). Regionales monitoring 2018. Daten und fakten - metropolregion FrankfurtRheinMain. Frankfurt, Germany.

Regionalverband. (2010). Regionalplan Südhessen / regionaler flächennutzungsplan, allgemeiner textteil of October 17, 2010. Darmstadt, Germany.

Röhring, A., \& Gailing, L. (2005). Institutional problems and management aspects of shared cultural landscapes: Conflicts and possible solutions concerning a common good from a social science perspective. Leibniz-Institut für Regionalentwicklung und Strukturplanung eV (IRS).Erkner, Germany.

Ronneberger, K., \& Keil, R. (1993). Riding the tiger of modernization: Red-green municipal reform politics in Frankfurt am main. Capitalism Nature Socialism, 4(2), 19-50. 
Schmidt, S., Siedentop, S. \& Fina, S. (2018) How effective are regions in determining urban spatial patterns? Evidence from Germany. Journal of Urban Affairs, 40(5), 639-656.

Schmidt, S. (2009). Land use planning tools and institutional change in Germany: Recent developments in local and regional planning. European Planning Studies, 17(12), 1907-1921.

Siedentop, S., Fina, S., \& Krehl, A. (2016). Greenbelts in Germany's regional plans-An effective growth management policy? Landscape and Urban Planning, 145, 71-82.

Sieverts, T. (2003). Cities without cities: An interpretation of the zwischenstadt. London, England: Routledge.

Sorensen, A. (2015). Taking path dependence seriously: An historical institutionalist research agenda in planning history. Planning Perspectives, 30(1), 17-38.

Stadt Frankfurt am Main. (2015). Prozessdokumentation: Specichen und strahlen Frankfurt am Main. Frankfurt am Main, Germany.

Stoker, G. (1998). Governance as theory: Five propositions. International Social Science Journal, 50(155), 17-28.

Storper, M. (2014). Governing the large metropolis. Territory, Politics, Governance, 2(2), 115-134.

Sturzaker, J., \& Mell, I. (2016). Green belts: Past; present; future? London, England: Routledge.

Stadt Offenbach. (August 4, 2017). 30 jahre grünring Offenbach: Wegweisende entscheidung gegen die südumgehung. Retrieved from https://www.offenbach.de/leben-in-of/planen-bauenwohnen/gruene_stadt/regionale_routen/dreissig-jahre-gruenring-offenbach-7.8.17.php

Wei, L. (2017). Multifunctionality of urban green space-An analytical framework and the case study of greenbelt in Frankfurt am Main, Germany. (Doctoral dissertation). Technische Universität Darmstadt, Darmstadt, Germany.

Willi, Y., Pütz, M., \& Müller, M. (2018). Towards a versatile and multidimensional framework to analyse regional governance. Environment and Planning C: Politics and Space, 36(5), 775-795.

Young, O. R. (2002). The institutional dimensions of environmental change: Fit, interplay, and scale. London, England: MIT Press.

Young, O. R., King, L. A., Schroeder, H., Galaz, V., \& Hahn, T. (2008). Institutions and environmental change: Principal findings, applications, and research frontiers: Cambridge, MA: MIT Press.

Zimmerbauer, K., \& Paasi, A. (2019). Hard work with soft spaces (and vice versa): Problematizing the transforming planning spaces. European Planning Studies, 1-19. 


\subsection{APPENDIX: CITED INTERVIEWS}

\begin{tabular}{llll}
\hline Interview No. & Position Title & Organization & Date \\
\hline 1 & $\begin{array}{l}\text { Municipal Planning } \\
\text { Official }\end{array}$ & $\begin{array}{l}\text { Environment Department, } \\
\text { Frankfurt }\end{array}$ & March 14, 2018 \\
\hline 2 & $\begin{array}{l}\text { Municipal Planning } \\
\text { Official }\end{array}$ & $\begin{array}{l}\text { Environment Department, } \\
\text { Frankfurt }\end{array}$ & September 22, 2017 \\
\hline 3 & Regional Planning & Regionalverband, Frankfurt & September 14, 2018 \\
& Official & Regionalpark Ballungsraum & May 14, 2018, \\
\hline 4 & Former Director & RheinMain GmbH, Flörsheim & June 14, 2018 and \\
& & am Main & September 9, 2018 \\
\hline 5 & Director & Regionalpark Ballungsraum & May 18, 2018, \\
& & RheinMain GmbH, Flörsheim & August 23, 2018 and \\
& am Main & July 15, 2019 \\
\hline 6 & Researcher & Technische Universität & March 8, 2018, \\
& & Darmstadt, Darmstadt & August 20, 2018 and \\
& & & July 18, 2019 \\
\hline 7 & Municipal Planning & Environment Department, & December 4, 2017 \\
& Official & Frankfurt & \\
\hline
\end{tabular}





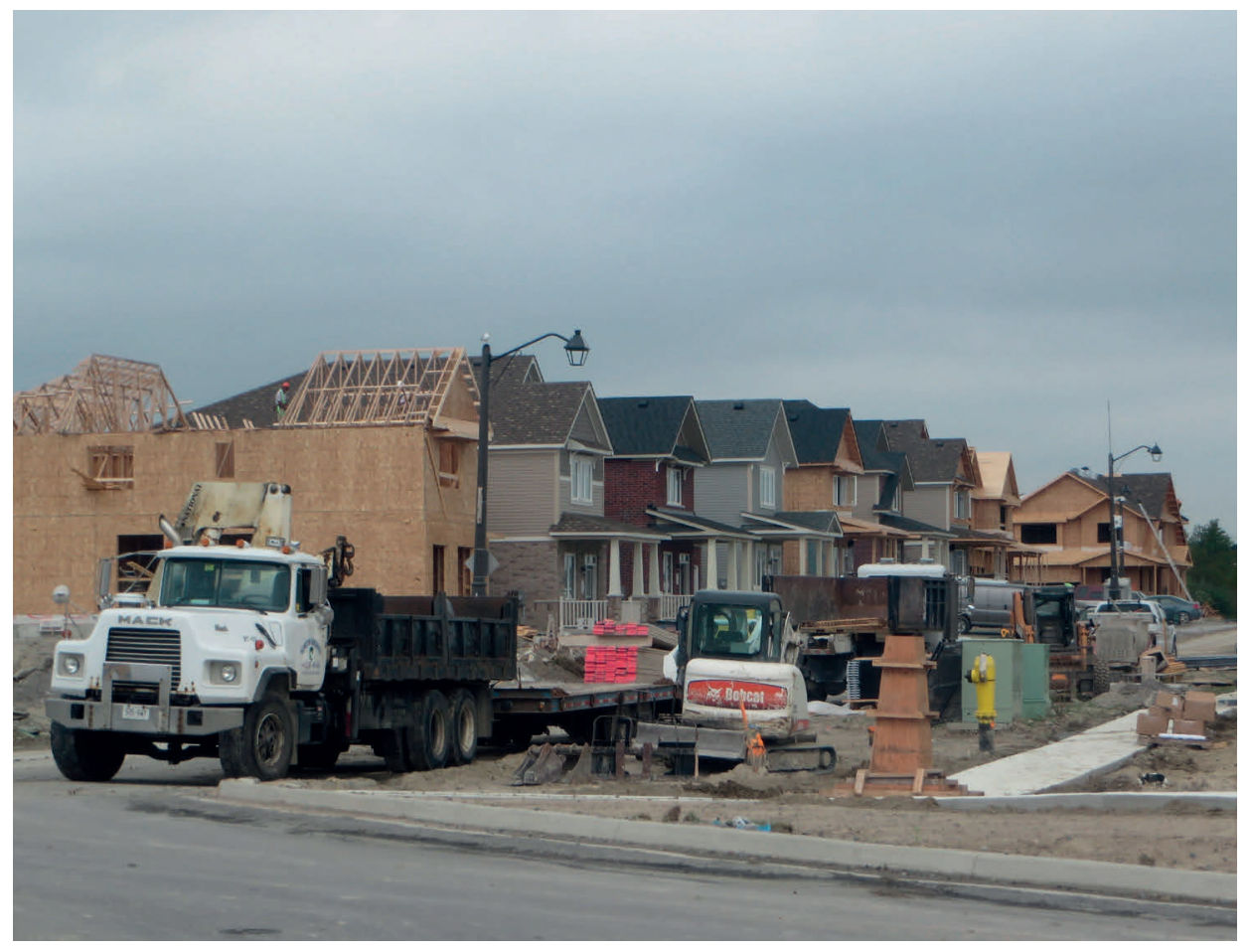

New residential development in Oshawa (2014).

Source: author 


\section{Towards smart regional growth: Institutional complexities and the regional governance of Southern Ontario's greenbelt}

Submitted as Macdonald, S., Monstadt, J., \& Friendly, A. Towards Smart Regional Growth: Institutional Complexities and the Regional Governance of Southern Ontario's Greenbelt. (under review). 


\section{ABSTRACT}

The task of developing regional greenbelts poses multi-dimensional challenges to policymakers. Unlike their early 20th century predecessors, these greenspaces incorporate multiple functions including growth management, farmland and environmental protection and increasing economic competitiveness. This regional and multi-functional approach is complex, as it increases the number of policy fields such as economic growth, agriculture, housing, nature conservation, stakeholders at different policy levels and in various territorial jurisdictions involved in greenbelt management. However, the institutional complexities and governance challenges of managing these contemporary greenbelts are hardly reflected within the literature. Given these literature gaps, we examine how the institutional environment of the Greater Golden Horseshoe region in Southern Ontario, Canada has influenced the implementation of its Greenbelt Plan during a 15-year period (2003-2018). By engaging with literature on the institutional dimensions of the governance of regional greenbelts, we analyse how this greenbelt's management has been influenced by vertical, horizontal, and territorial coordination challenges and politics at the provincial and local levels. We conclude that institutional coordination problems have resulted in uneven greenbelt and smart growth policy implementation and produced unintended outcomes, which undermine greenbelt management, preventing these policies from delivering the significant regional land-use changes promised by the Ontario government.

\section{Keywords}

greenbelts; smart growth; regional governance; institutions; Greater Golden Horseshoe. 


\subsection{INTRODUCTION}

Greenbelts originated in late $19^{\text {th }}$ century and early $20^{\text {th }}$ century efforts to preserve European urban greenspaces, spreading from England internationally after the Second World War (Amati and Taylor, 2010). Such greenspace protections have since been established in other locations including Melbourne, Seoul, Copenhagen, and Toronto. While greenbelts were originally designed to maintain city-countryside divisions, over the past thirty years, a new generation of greenbelts has emerged (Sturzaker and Mell, 2017). These greenbelts pursue more ambitious policy goals than did their predecessors, including protecting natural habitats and farmland, containing urban growth, incorporating smart growth principles, and contributing to economic development. Yet given these comprehensive policy objectives, many more stakeholders are involved in greenbelt policy implementation, including farmers, environmentalists, and local officials. Effective greenbelt management also requires coordination across several policy fields such as agriculture, nature conservation and housing, as well as engagement with public, private, and civil society actors at all policy levels. In addition, regional greenbelts involve territorial coordination across numerous administrative jurisdictions. While greenbelts create a firm barrier to urban growth that protects farmland, these policies can also push urban development further out into a region creating unintended environmental problems. Greenbelt and other smart growth policies challenge deeply entrenched low-density development practices. However, the politics involved in effectively implementing these policies requires balancing competing stakeholder interests, which can be difficult given the influence of local growth coalitions. Therefore, these institutional complexities and political influences present challenges for policymakers to manage $21^{\text {st }}$ century greenbelts. Yet regional greenbelt policies are not implemented by a single governmental institution, but rather require coordination across governments at several levels, and with the private and civil society sectors. Thus, these policies blur traditional vertical, horizontal, and territorial institutional policy-making arrangements.

Despite the complicated nature of this new generation of greenbelts, regional governance debates rarely focus on the institutional and political complexities of governing greenbelts. We address this literature gap by analysing how greenbelt governance is impacted by the institutional environment in which the greenbelt is situated. More specifically, we address how greenbelt and smart growth policies are coordinated between different policy levels (vertical coordination), stakeholder groups (horizontal coordination) and across the territorial jurisdictions of various municipalities (territorial coordination), along with the politics involved in these coordination processes. We take the greenbelt in the rapidly growing Greater Golden Horseshoe (GGH) region in Southern Ontario, Canada as our empirical case study. Established in 2005, the GGH greenbelt was designed to preserve farmland and natural 
areas, contain urban growth, and provide recreational spaces. The greenbelt stretches across the $\mathrm{GGH}$, a region characterized by its strong regional economy, multicultural population, and intensifying urban and suburban growth pressures. Given this context, we ask the following questions: how can greenbelt and smart growth policy implementation be better coordinated across numerous municipal jurisdictions, policy domains and policy levels? In addition, what insights can be drawn for policymakers and more broadly, for regional governance debates?

This article focuses on a 15-year period (2003-2018) in Ontario's history under a Liberal government. This research is based on 43 interviews conducted in the GGH region between August 2014 and June 2019 with municipal and provincial planners, and representatives from environmental and farming organizations. Interview participants were selected to include key stakeholder groups responsible for greenbelt management. The interviews focused on how greenbelt and smart growth policy implementation has been influenced by coordination and political challenges between provincial and municipal governments, prominent stakeholders and across multiple municipalities. Using our conceptual framework on three dimensions of institutional coordination, interview transcripts were analysed to identify how the institutional environment impacts greenbelt policy implementation. A range of empirical literature including provincial planning documents, media articles and foundation reports were also reviewed for this research. Our article is structured as follows: first, we review literature on greenbelt and smart growth debates, the institutional complexities of regional greenbelt governance, and summarize the conceptual framework applied to this research. Following that, an overview of the GGH region, the greenbelt and the regional growth plan is provided, focusing on institutional complexities. Through a discussion of vertical, horizontal, and territorial institutional coordination, we argue that coordination problems have resulted in uneven greenbelt and smart growth policy implementation and produced unintended outcomes. Ultimately, these problems undermine effective greenbelt management and prevent these policies from delivering the fundamental changes originally promised by the Liberals' ambitious planning framework for the GGH region.

\subsection{THE GOVERNANCE OF REGIONAL GREENBELTS: AN INSTITUTIONAL PERSPECTIVE}

Contemporary greenbelts are designed to respond to more complex challenges than those from the early $20^{\text {th }}$ century. With roots in the English Garden City movement, greenbelts were originally designed to separate cities and countryside, protect agricultural land, and provide greenspaces for urban residents (Amati and Yokohari, 2006). Seen as the "universal solution to [control] urban growth", greenbelt policies ultimately spread internationally, 
taking on numerous forms and functions based on each jurisdiction's institutional arrangements (Amati, 2008, 9; Han and Go, 2019). Since that time, the original greenbelt concept has evolved due to societal changes including globalisation and suburbanisation, requiring new institutional arrangements for greenbelt planning. Thus, a new generation of greenbelts has emerged in recent decades with comprehensive policy goals. In addition to protecting farmland and containing urban growth, these multi-functional greenbelts provide numerous benefits including ecosystem services and contributing to economic development and regional identity. Also, because of growing regionalisation pressures, policymakers have taken a broader regional approach to some recent greenbelt policies, reflecting an upscaling of urban-regional regulation to new policy levels (Macdonald and Keil, 2012). However, there is increasing pressure from developers to reform long-standing greenbelt policies including those in the UK, and a shift towards flexible greenspace protection models, such as green infrastructure (Sturzaker and Mell, 2017).

As greenbelts and urban growth boundaries are major approaches to achieve compact urban development, they have also become a key component of smart growth agendas. In the past two decades, smart growth emerged in the North American planning discourse as a reaction against low-density development (Grant, 2009). Smart growth principles include mixed land-uses, compact development, transit-accessible communities and establishing multi-actor governance partnerships necessary for policy implementation which often reach across territorial boundaries (Krueger and Gibbs, 2008; Scott, 2007). While smart growth approaches have become popular, they can also create conflicts amongst local stakeholders (Hawkins, 2014). These types of policies have substantial effects on redistributing the costs and benefits of land development, creating power struggles between smart growth advocates such as environmental groups and pro-growth interests including developers (ibid.; Ramirez de la Cruz, 2009). Thus, political institutions must mediate these competing demands, with economic interests forming local growth coalitions that often disproportionately influence smart growth policy decisions (Logan and Molotch, 1987; Ramirez de la Cruz, 2009). While the smart growth literature focuses on policy evaluation (Hawkins, 2014; Ramirez de la Cruz, 2009), some debate has been more critical about implementation of these policies (Filion and McSpurren, 2007; Grant, 2009). However, the territorial politics of smart growth and greenbelts are hardly reflected within this literature, with some exceptions (Dierwechter, 2013).

Given that new generation greenbelt management is an inherently political process involving collaboration between diverse stakeholders at multiple policy levels and across administrative jurisdictions, a regional governance perspective is needed to analyse greenbelt implementation. Indeed, reflecting recent trends of state spatial re-organization (Brenner, 2004), greenbelt planning has evolved to include complex relationships involving 
institutions and stakeholders that include but also go beyond governments. The governance of regional greenbelts thus occurs through "the vertical and horizontal coordination of regional transformation processes beyond administrative boundaries by state and nonstate actors" (Willi et al., 2018, 12). Greenbelt management increasingly involves nongovernmental agencies and civil society groups, reflecting recent trends to contract out service delivery to the private sector and community-based organizations (Obeng-Odoom, 2012). However, greenbelt implementation also occurs in a politically contested context that seeks to reconcile the conflicting demands of urban growth and nature conservation. Thus, new generation greenbelt management requires a high level of negotiation and coordination with these diverse groups to achieve policy goals. However, power imbalances between these stakeholders make greenbelt policies vulnerable to being undermined by municipal politics and the politics of local growth coalitions.

Greenbelts have been discussed as part of new forms of multi-scalar regionalism (Addie and Keil, 2015), as an upscaling of urban-regional regulation to new policy levels (Macdonald and Keil, 2012), and as a way that nature can be used to legitimate growth management (Wekerle et al. 2007). However, greenbelts are hardly examined in the regional governance literature. Moreover, the institutional dimensions of greenbelt governance are rarely discussed, with some exceptions (Han and Go, 2019; Mace, 2018; Pond, 2009). In this article, we address these theoretical gaps to explore the institutional and political complexities of the governance of regional greenbelts.

Similar to other environmental policies, institutional settings significantly influence greenbelt planning and their implementation challenges (Briassoulis, 2004). Thus, the design of greenbelts as elements of smart growth policies reflects their institutional environment and the "political economy of anti-sprawl regulation" (Pond, 2009, 239). Depending on a jurisdiction's land-use planning laws, a range of planning regulations such as zones or designations may be available to protect greenspaces, resulting in the diversity of greenbelt spatial forms and policy goals seen internationally (Taylor, 2019). Greenbelt management happens within complex institutional arrangements. We view institutions as rules and practices that are embedded within structures, which are relatively stable in the face of changing circumstances (March and Olsen, 2011). Following this definition, institutions create order, distribute power relations, affect actors' behaviour, and are shaped by politics, representing the coordination of structures needed for decision-making processes (ibid.). Within the literature, the key analytical approaches include rational choice institutionalism, sociological institutionalism, and historical institutionalism, each exploring how institutions shape actors' interactions (see Peters, 2019). Indeed, institutional development and change have long been at the centre of governance debates, and institutions have been viewed as essential for 
regional governance (Galland and Harrison, 2020). Despite this agreement, there is academic debate about how to properly govern urban regions. Key approaches include the metropolitan reform model, the public choice school, and new regionalism (see Glass, 2018; Savitch and Vogel, 2000). Also, there are several analytical frameworks to conceptualize the governance of urban regions (see Foster and Barnes, 2012; Galland and Harrison 2020), yet these approaches do not focus on institutions.

Therefore, to analyse the role of institutions in greenbelt management, we identify three dimensions shaping the effectiveness of the governance of regional greenbelts: vertical, horizontal, and territorial institutional coordination ${ }^{18}$. Vertical coordination results from the interdependencies between stakeholders at different policy levels - municipal, regional, or provincial. The coordination of greenbelt and smart growth policies between different policy levels has a substantial impact on these policies' implementation. Greenbelt policies are usually set by senior levels of government and implemented by a lower government authority (Carter-Whitney, 2010). Often, uneven power relations between these policy levels result in coordination and implementation problems.

In addition to these vertical coordination challenges posed by the institutional design of greenbelt policies, different departments within a specific government level play a role in policy implementation (ibid.). This highlights how horizontal coordination involves the interaction between stakeholders or institutions at the same policy level. In the case of greenbelt and smart growth governance, horizontal coordination includes various policy domains - land-use planning, nature conservation and agriculture - as well as the communities shaping these domains including private stakeholders and citizen initiatives. Pro-growth interests such as developers often try to influence politicians at all policy levels. Given that these stakeholders tend to have access to considerable financial resources, they can significantly shape land management policies (Hawkins, 2014).

At the same time, administrative jurisdictions rarely match a greenbelt's boundaries, resulting in territorial coordination problems and possible institutional "misfits" (Young, 2002). Regional greenbelt and smart growth policy management involves coordinating across multiple administrative jurisdictions, creating conflicts that can arise along these borders that influence effective policy implementation. Each of these types of coordination is interrelated, contested by stakeholders amidst power dynamics. Without strong guidance from senior government authorities about how coordination between these three institutional dimensions should occur, greenbelt and smart growth policy implementation may become vulnerable to politics and the influence of local

18 For analytical categories that are comparable, see Young et al., 2008; Young, 2002. 
growth coalitions. Bringing together these three forms of institutional coordination allows for an analysis of the institutional complexities of greenbelt governance to examine the difficulties of managing new generation greenbelts, which we discuss later in the article. Based on this framework for the institutional complexities of the governance of regional greenbelts, in the next section we provide an overview of the GGH region and the legislation related to its greenbelt.

\subsection{KEY POLICIES OF THE LIBERALS' REGIONAL PLANNING FRAMEWORK FOR THE GGH REGION}

As one of the fastest growing regions within North America, the GGH region covers approximately 32,000 square kilometres composed of large cities including Toronto, midsized cities and towns, and overall, a total of 110 municipalities (see Figure 5.1) (Allen and Campsie, 2013). With a population of approximately 9 million people as of 2016, the region is predicted to grow to 13.48 million people by 2041 (Ministry of Municipal Affairs and Housing, 2019). The GGH is institutionally complex, including the Ontario provincial government, a municipal level divided between upper, lower, and single tier municipalities, and a range of special purpose bodies. ${ }^{19}$ Ultimately, this institutional structure creates coordination and governance challenges.

Moreover, the establishment of the GGH region's greenbelt resulted from several planning and governance failures. Between the late 1970s and the early 2000s, the Toronto region lacked a regional planning body and regional plan (White, 2007). Given that the Conservative government at the time (1995-2003) had weakened planning legislation that ultimately encouraged suburban growth, residential development remained unregulated (Frisken, 2001). By the late 1990s, increasing public and political awareness of urban sprawl-related problems and development proposals in the Oak Ridges Moraine fuelled the creation of concerned citizen initiatives (Sandberg et al., 2013). These groups later became a driving force behind the greenbelt's creation. As these conditions intensified, the Conservatives protected the Oak Ridges Moraine and created a series of Smart Growth panels, inspired by American smart growth ideas (Taylor, 2013). With regional planning back on the provincial agenda, in 2003, a newly elected Liberal government under Premier

19 There are 21 upper and single-tier and 89 lower-tier municipalities in the GGH region, which divide responsibilities for municipal services between these levels of governments. Upper-tier municipalities are usually counties or regions within which there are several lower tier levels of municipal government. Single-tier municipalities are usually large cities where services are delivered by that level of government alone (Allen and Campsie, 2013). 
Dalton McGunity capitalized on the groundwork laid by the Conservatives, proposed a greenbelt, and rebranded the prior smart growth agenda as "Places to Grow". The Liberals did what no previous government had done in the past 40 years: they implemented a regional plan for the greater Toronto region (ibid.). In their first years in office, the Liberal government established an ambitious planning framework for the GGH designed to achieve their regional vision.

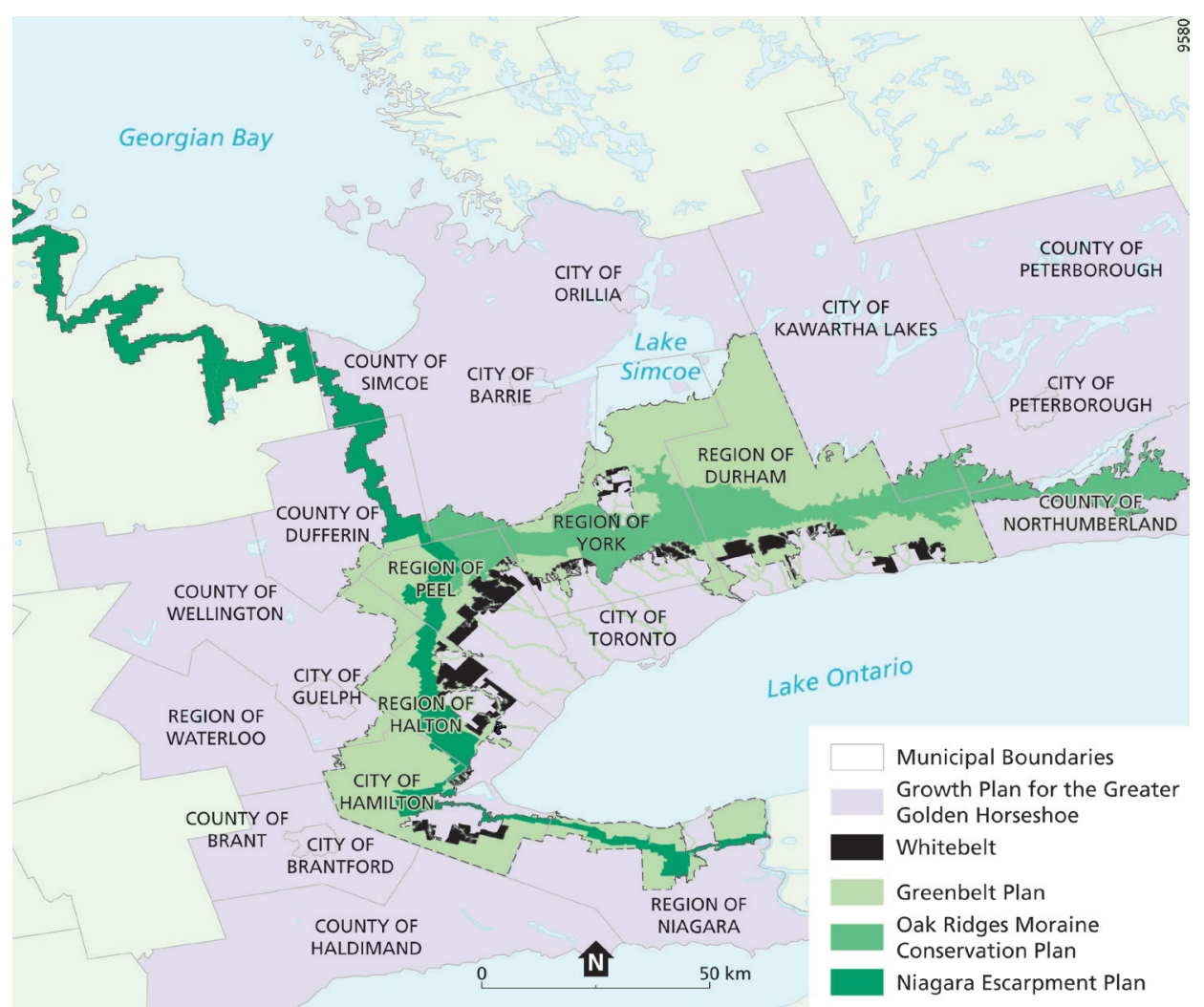

\section{Figure 5.1: The Greater Golden Horseshoe Region}

Sources: Ministry of Municipal Affairs and Housing, 2019; Ministry of Municipal Affairs, 2017

Billed as the largest permanently protected greenbelt in the world, the GGH greenbelt spans approximately 720,000 hectares and integrates areas that were previously preserved under the Niagara Escarpment Plan and the Oak Ridges Moraine Conservation Plan (Friends of the Greenbelt Foundation, n.d.). In 2005, the Greenbelt Act was passed by the provincial government (referred to herein as the Province), allowing for the creation of a Greenbelt Plan, also released that year. The Greenbelt Plan addresses multiple policy fields including 
agriculture, nature conservation and infrastructure, and is designed to protect against the loss of farmland and natural heritage systems, and to mitigate climate change (Ministry of Municipal Affairs, 2017). Developing strong stakeholder support is key to the long-term success of a greenbelt, which the Liberals facilitated by providing \$25 million CAD for the creation of the Friends of the Greenbelt Foundation to promote the greenbelt through education programs. The Province also created a Greenbelt Council of experts from stakeholder groups to provide guidance to the Minister of Municipal Affairs and Housing about plan implementation. However, the Liberals made a strategic political decision not to create a special purpose body to oversee the greenbelt's management, which would create yet another organization they could not control and instead retained responsibility for the greenbelt within the Province (Interview 1). In the time since the greenbelt began, there has been a positive shift in discourse surrounding the greenbelt (Interview 2; Interview 3). Indeed, the greenbelt was initially politically contentious, and contested by farmers, developers, and municipalities. However, these stakeholders' initial objections have been replaced with acceptance, representing an achievement towards the effective governance of the greenbelt. The Greenbelt Plan has benefited from dedicated stakeholder support in addition to the foundation's activities, resulting in broad public support for the greenbelt.

From the beginning, the Greenbelt Plan was designed to work together with a regional growth plan. The Greenbelt Plan identifies where urbanization cannot occur to protect farmland, while the "Places to Grow" legislation designates how and where to accommodate urban growth. In 2005, the province passed the Places to Grow Act as a foundation for preparing growth plans in Ontario. The first of these plans to be released was for the GGH in 2006. Based on smart growth principles, this 25-year growth plan was designed to manage the region's growth until 2031 (now extended to 2041), outline population projections, and encourage intensification in 25 urban growth centres (Ministry of Municipal Affairs and Housing, 2019)..$^{20}$ Provincial staff review the Greenbelt and Growth Plans every 10 years to assess their effectiveness. Thus, the greenbelt is strongly protected because it is only during this review process that the Minister of Municipal Affairs and Housing can make amendments to protected areas within the greenbelt. However, such changes are not allowed to decrease the total area of the greenbelt (Ministry of Municipal Affairs, 2017). The Province launched the first simultaneous review of the Greenbelt Plan, the GGH Growth Plan, the Niagara Escarpment Plan, and the Oak Ridges Moraine Conservation Plan in 2015. For the coordinated review of these four plans, the Province appointed an advisory panel, and based on that panel's findings and public consultations, revised plans were released in 2017.

20 Urban growth centres are in the downtown areas of the region's mid-sized cities and are the focus of public service investment, serve as employment centres, and accommodate significant population growth (Ministry of Municipal Affairs and Housing, 2019). 
The institutional design of the Greenbelt and Growth Plans are based on a vertical hierarchical structure that fits within Ontario's provincially led land-use planning system (Figure 5.2).

The Planning Act

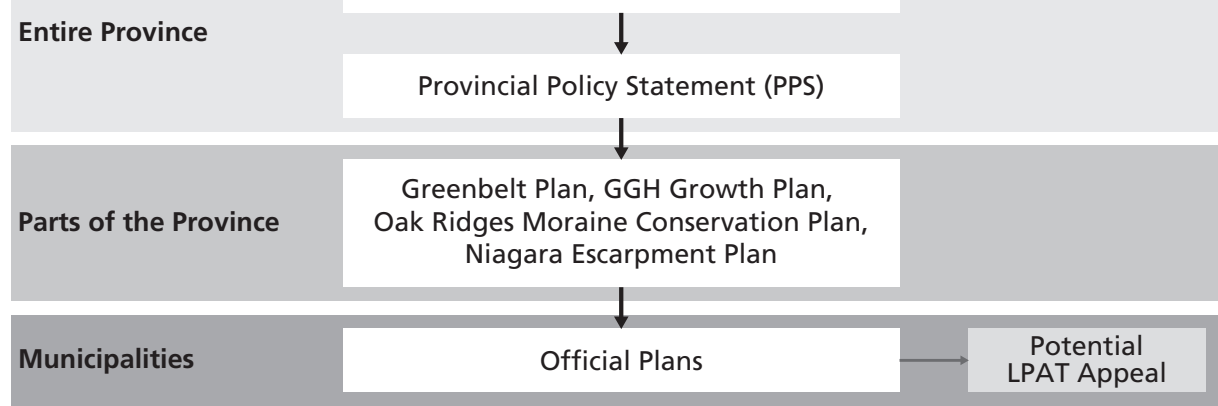

Figure 5.2: Ontario's Land-Use Planning System

Source: author

Through the Planning Act and the Provincial Policy Statement, the Province provides direction for land-use planning in Ontario. Within specific areas of the province, provincial plans have more detailed policies to meet certain goals such as the GGH Growth and Greenbelt Plans. Municipalities must then implement these provincial policies through their official plans. In cases of disputes related to municipal planning decisions, appeals can be made to the Local Planning Appeal Tribunal (LPAT). As a quasi-judicial administrative tribunal that makes decisions about municipal land-use planning matters, the LPAT provides an important dispute resolution function in Ontario's land-use planning system. In the next section of the article, we analyse the governance and institutional problems of implementing the GGH greenbelt.

\subsection{THE INSTITUTIONAL CHALLENGES AND TERRITORIAL POLITICS INVOLVED IN IMPLEMENTING THE GREENBELT PLAN}

In this section, we explore how greenbelt governance is coordinated between public, private, and civil society actors at different policy levels, in diverse policy fields and across jurisdictions within the GGH region. Through our analytical lens of vertical, horizontal, and territorial coordination, we analyse the politics and challenges faced during the first 15 years of greenbelt implementation in Ontario. 


\subsubsection{Vertical coordination: Greenbelt development as an articulation of provincial- municipal relations}

The Greenbelt Plan provides an excellent illustration of vertical institutional coordination. Indeed, the implementation of these policies can be seen as the geographical articulation of provincial interests at the municipal level. Provincialmunicipal relations in Ontario reflect complicated arrangements of shared responsibilities, power asymmetries and coordination problems that influence Greenbelt Plan implementation. During their time in office, the Liberal government tried to improve provincial-municipal relations, which was necessary for the success of regional planning policies. Indeed, provincial-municipal relations in Ontario are still strongly influenced by the legacy of $19^{\text {th }}$ century legislation that reinforces uneven power relations by limiting municipal authority, making municipalities subordinate to the Province (Côté and Fenn, 2014). Since the early 2000s, provincial-municipal relations have evolved with updated legislation including the Municipal Act, 2001 and the City of Toronto Act, 2006, providing municipalities more autonomy and reflecting a less prescriptive provincial approach (ibid.). The late 1990s and early 2000s marked a turbulent political period of major municipal institutional reforms initiated by a Conservative government including forced amalgamations (ibid.). The Liberals sought to rebuild this conflictual provincial-municipal relationship that had been damaged by the territorially divisive politics of their Conservative predecessors which favoured suburban municipalities over the urban core (Addie and Keil, 2015). In contrast to the Conservative approach, the Liberals appeared to view local governments as partners, significantly increasing provincial support for municipalities through municipal enabling legislation (Côté and Fenn, 2014; Henstra, 2017).

The Liberals further committed to regional planning by introducing ambitious land-use policies including the Greenbelt and Growth Plans, created a regional transportation agency known as Metrolinx, and strengthened land-use planning laws. The greenbelt policy design fits well within the existing institutional arrangements, as the Province has the authority to set Ontario's land-use planning frameworks (Pond, 2009). As a result, the Liberals faced no institutional barriers to establishing the greenbelt and had no legal obligation to compensate landowners. The Liberals could also distance themselves from local politics given that municipalities are responsible for implementation (ibid.). An institutional weakness of the Greenbelt and Growth Plans, however, is that their effective implementation is dependent upon consistent provincial support, otherwise the politics of economic interest groups may undermine these polices. Moreover, Ontario has a history of fluctuating provincial political involvement in regional affairs. While the Liberals promoted a regional agenda at this time, the provincial government had slowly retreated from playing a more engaged regional role during the last half of 
the $20^{\text {th }}$ century (Frisken, 2001). The Ontario government's history of benign neglect of regional affairs thus raises questions about the status of the Greenbelt Plan when provincial priorities' change, and how to ensure the long-term success of this plan, given this political context.

Also, there has been an institutional void at the regional level within the Toronto area for decades. With the establishment of the Growth Plan, the Liberals introduced a new policy level: the Greater Golden Horseshoe, fixing regional issues at a new territorial scale ${ }^{21}$. However, the Liberals stopped short of creating a formal regional government for the GGH, instead taking the role as the regional government in absentia, which has been common practice throughout Ontario's regional governance history (Frisken, 2001)22. While a regional government was a key recommendation of the 1996 report of the Greater Toronto Area Task Force studying regional governance reform, since that time, only the Greater Toronto Services Board was established in 1998 to coordinate regional services, yet was dissolved by 2001 (White, 2007). Due to this continued institutional void, the provincial response has been to create numerous GGH specific policies to direct municipal action, creating coordination problems and ultimately influencing policy implementation.

Despite the Liberals' efforts to improve municipal relations, the Greenbelt and Growth Plans reinforce the traditional hierarchical provincial-municipal relationship of uneven power relations, with institutionalized vertical coordination influencing policy implementation. While some municipalities resent what they perceive as unfair provincial restrictions placed upon them, others have settled into a "culture of comfortable subordination," blaming the Province for problems that might arise (Henstra, 2017; Siegel, 2009, 65). Despite recent municipal legislative reforms, power asymmetries are evident as municipalities still operate in an uncertain political environment, where shifts in provincial interests can alter local resources and responsibilities (Henstra, 2017). Challenges in the vertical institutional arrangements needed to implement the Greenbelt and Growth Plans are reflected in municipal non-compliance and resistance to these provincial policies. With recent municipal legislative changes as well as inconsistencies in the initial policies, municipalities have freedom to pursue different strategies to achieve provincial policy goals, resulting in problems in the initial phase of Greenbelt and Growth Plan implementation. Therefore, in the 2015 policy review, for example, provincial planning staff took a prescriptive approach by closing policy loopholes and providing municipalities less flexibility to achieve plan

21 The GGH has been recognized as a geographic region for decades but was only established as a policy level in the 2006 Growth Plan.

22 A regional government refers to a formal level of government located between the GGH's municipalities and the provincial government. 
outcomes, causing conflict with municipalities (Interview 4). Thus, while cooperation between the Province and municipalities has recently become the norm, the Ontario government remains firmly in control and will assert its authority to ensure municipal compliance, if needed (Henstra, 2017).

In addition to provincial-municipal relations, special purpose bodies have a substantial impact on Greenbelt and Growth Plan implementation. The Ontario Municipal Board (OMB) was a quasi-judicial tribunal that was situated at a policy level between the Ontario government and municipalities and heard appeals on municipal planning decisions (Siegel, 2009). As the most powerful board of its kind in North America, the controversial OMB had significant power to disregard local decisions by substituting its own decision for local council rulings (Moore, 2013). One example of such disregard occurred in 2009 when the Region of Waterloo adopted a new regional official plan focused on smart growth principles. Following an OMB appeal by developers, in 2013 the board's ruling favoured the appellants' case to allow 1053 hectares of land for urban development by 2031, significantly higher than the 85 hectares deemed appropriate by the Region (Region of Waterloo, 2015; Smart Growth Waterloo Region, n.d.). Waterloo's planning staff spent years defending its official plan before the case was settled in 2015 (ibid.). This example highlights how the OMB undermined local political processes by removing municipal oversight from land-use planning (Moore, 2013). The OMB also reinforced unequal power relations between stakeholders, as involvement in hearings was expensive for civil society groups and developers would often try to avoid the municipal planning process entirely by focusing on appeals to the board instead (ibid.). The Liberals reformed the OMB by reducing its scope of power to override municipal decisions, renaming it the Local Planning Appeal Tribunal (LPAT) in 2018. It is uncertain at the time of writing what future impact the LPAT might have. However, this case shows that while special purpose bodies' mandates evolve over time, these agencies strongly influence land-use planning outcomes and municipal politics ${ }^{23}$.

To conclude, at first sight it appears that the Greenbelt Plan's vertical institutional design is effective given that the Province sets the planning framework that is implemented by municipalities. This comes with advantages as the Province has the strong authority to shape smart growth policies. Upon closer examination, however,

23 In 2019, the Ontario legislature under a Conservative government passed the More Homes, More Choices Act, with far-reaching implications for environmental protection and land-use planning. As part of this legislation, significant amendments were made to the planning appeal process that reversed the changes introduced by the Liberals. While the LPAT retains its name, this agency will reinstate many of the old $\mathrm{OMB}$ procedures, highlighting the influence of changing political regimes on special purpose bodies' mandates (Ryerson City Building Institute, 2019). 
we find that this vertical institutional design translates into considerable challenges of horizontal coordination at the local level influencing Greenbelt Plan implementation, which will be discussed in the next section.

\subsubsection{Horizontal coordination: How politics and stakeholder self-interests undermine greenbelt implementation}

Despite the benefits of the vertical institutional design of greenbelt and smart growth policies and some gradual improvements in provincial-municipal relations, trade-offs at the municipal level are also a feature of this institutional context. Indeed, horizontal coordination at the local level is reflected through relationships with municipalities, developers, and farmers, contributing to uneven Greenbelt and Growth Plan implementation. There have been diverse municipal reactions to these plans, reflecting the complexity of the GGH region's municipal structures. With 110 municipalities including large cities and rural communities, GGH municipalities have varying administrative capacities and development perspectives. Many municipalities have embraced the Greenbelt Plan by pursuing their own initiatives with local organizations to further support greenbelt policy goals (Hertel and Markovich, 2015). Thus, the Greenbelt Plan has become a mechanism to facilitate better governance practices. For example, increased opportunities for stakeholder participation have resulted through the creation of new organizations including the Friends of the Greenbelt Foundation and the Greenbelt Farmers Market Network. In addition, the Greenbelt Plan has benefitted from committed leadership in all sectors that strongly defend this greenspace's protection.

At the same time, some municipalities view the greenbelt as "strangling them" due to the policies' land-use restrictions which could impede their economic viability to attract new residential development and hinder their reliance on traditional revenue generating mechanisms such as development charges (Interview 2). ${ }^{24}$ Some municipalities eager to attract new development become accommodating to developers and low-density development, creating conditions that conflict with regional planning (Filion, 2003). These municipalities can be seen as "growth machines", which are significantly influenced by the politics of local growth coalitions who dominate local decision-making processes (Logan and Molotch, 1987). In Ontario, developers significantly influence municipal politics by financing local election campaigns. The non-profit organization Campaign Fairness Ontario (2016) finds that the development industry is a major supporter of local political

24 Development charges, used by municipalities to pay for the capital costs of growth, are defined as "a per-unit levy to cover the cost of municipal services to property and the neighbouring community in addition to the physical services developers install themselves" (Côté and Fenn, 2014, 49). 
candidates $^{25}$. For example, in the 2014 municipal election, the development community strategically donated in specific ridings, particularly in areas outside the greenbelt which have less development restrictions (ibid.). Through these donations, the development industry affects municipal election results, leading to the creation of local councils more favourable to their economic development interests (ibid.; MacDermid, 2006). These practices highlight the uneven power relations involved in growth politics, as these developers have the financial resources to influence municipal elections, undermining democratic processes. While these municipalities must adhere to provincial planning laws, they may not entirely accept these policies. For instance, during the initial phase of the Growth Plan's implementation, many municipalities were resistant to these policies and applied the lowest possible intensification targets allowed by the plan (Burchfield, 2016). Thus, this pro-growth mentality of local councils in some municipalities creates conflicts with the advocates of the Greenbelt and Growth Plans including environmental groups and progressive planners. These business-as-usual development practices ultimately undermine the smart growth principles of these policies.

Beyond the influence of municipalities, greenbelt implementation has also been impacted by problems of horizontal coordination across policy domains. The many land-use and transportation policies for the GGH region - including the Greenbelt Plan, the Growth Plan, the Oak Ridges Moraine Conservation Plan, the Niagara Escarpment Plan, and the regional transportation plan - have created numerous conflicts. In particular, inconsistent language between these GGH specific planning policies challenges implementation, given the varied land-use allowances and regulatory frameworks of each plan. Given the contradictions between these plans, local planners make their own judgements based on their municipal context (Interview 5). Also, the Growth Plan's initial implementation was faced problems such as delays with updating local official plans to conform to provincial policies. These issues resulted, ultimately, in inconsistent policy implementation (Allen and Campsie, 2013; Burchfield, 2016).

As a result of these horizontal coordination concerns, provincial staff attempted to harmonize the language among the revised 2017 plans to reduce potential conflicts (Interview 6). The Liberals also made changes to internal organizational governance to improve their role in policy design and implementation. While the Greenbelt and Growth Plans were initially located in separate ministries, both policies were later moved under the authority of the Ministry of Municipal Affairs and Housing. In addition, the 2015 policy

25 In Ontario, the development industry includes development companies that purchase land and supervise the development process, and development related companies. Few developers conduct all aspects of land development (e.g. land assembly, building completion and sales), while much of the work is contracted out to construction or finance-related companies (MacDermid, 2006). 
review increased provincial staff collaboration between different ministries, translating into a more integrated policy-making process, while the Greenbelt Council was expanded to include a larger membership of greenbelt experts (Interview 6). Finally, ahead of the 2015 policy review, provincial staff established performance monitoring indicators for the Greenbelt and Growth Plans to evaluate their progress in achieving their goals. However, the Liberals also attempted to silence critical voices from within the civil service. In one case, for example, a senior provincial planner was demoted for defending the Greenbelt and Growth Plans in the media (Gray, November 8, 2018).

The impacts of these horizontal coordination problems related to policy implementation are experienced first-hand by farmers, as they are most directly affected by the Greenbelt Plan. While protecting farmland is necessary to prevent its loss to development, the Greenbelt Plan alone is not enough to ensure a sustainable agricultural industry, given the significant constraints to Ontario's farms. Caldwell and Proctor (2013) find that farmers appreciate the benefits that the Greenbelt Plan offers in protecting farmland. However, policy complexities along with horizontal coordination problems at the provincial and municipal levels create landowner frustration. Farmers face difficulties navigating the many provincial and municipal policies applying to their land, including the Greenbelt, Oak Ridges Moraine and Niagara Escarpment Plans, endangered species regulations and conservation authority rules (ibid.). There are also concerns about inconsistent interpretations of provincial policies across different municipalities, conservation authorities and provincial ministries, and a lack of clarity from municipal planners about what is allowed under these policies (ibid.; Interview 7). Thus, while the Greenbelt Plan provides an excellent basis for protecting farmland, other government programs to support the economic viability of the agricultural sector are needed to ensure a sustainable working countryside.

Overall, horizontal, and vertical coordination problems are strongly inter-related in the case of Ontario, as the vertical institutional design of the Greenbelt and Growth Plan creates considerable coordination problems at the local level. The horizontal coordination challenges outlined here have resulted in uneven policy implementation between municipalities and frustration for landowners, influencing the effectiveness of these plans to achieve the Liberals' regional vision for the GGH.

\subsubsection{Territorial coordination: How leapfrogging reveals unintended impacts of the Greenbelt Plan}

The misalignment between administrative and functional spaces in Southern Ontario is problematic as a result of institutional misfits, which both creates territorial conflicts and influences stakeholder collaboration (Young, 2002). Significant coordination problems for greenbelt implementation result from the overlapping territorialities and different spatial 
scopes of the numerous policies applied to the GGH region. Covering the entire GGH region, the Growth Plan has a larger spatial scope than does the Greenbelt Plan (see Figure 5.1). However, the Greenbelt builds upon the Oak Ridges Moraine and Niagara Escarpment, and each has its own territorial scope and dedicated policies. The Growth Plan further divides the region into an inner ring (urbanized municipalities) and an outer ring (rural communities). ${ }^{26}$ In addition, the regional transportation agency Metrolinx covers a different territory, focusing on the Greater Toronto and Hamilton Area (GTHA). There is also inconsistency regarding regional greenspace management: while conservation authorities are organized at a watershed level, the greenbelt and Oak Ridges Moraine are managed by the Ministry of Municipal Affairs and Housing, the escarpment is overseen by the Niagara Escarpment Commission, and parts of the greenbelt operate as municipal, provincial or federal parks. These overlapping territorialities create problematic implementation; some policies are organized for the whole province (the Provincial Policy Statement), others for the GGH region (Growth Plan), and many at functional sub-GGH regions (Greenbelt Plan). These multiple, partially overlapping jurisdictions create coordination problems, conflicts between stakeholders and challenge effective greenbelt management.

A more adequate institutional design to achieve smart growth would be to integrate the Greenbelt Plan into the Growth Plan, forming a cohesive regional policy framework for the GGH, which did not happen with the first versions of these plans. In the 2015 review, while provincial staff did not merge the Greenbelt, Oak Ridges Moraine, Niagara Escarpment and Growth Plans into an integrated policy framework, they increased the consistency between these plans to create a more unified policy design (Interview 8). In addition, some elements of the greenbelt, including natural heritage and agricultural systems, were added to the 2017 Growth Plan to better integrate these two plans (Interview 8). Despite these promising efforts, the coordination of multiple territorial scopes of different policies within the GGH creates significant challenges for municipal implementation. While the Growth Plan allocates future municipal population growth, having the necessary infrastructure to support such growth has yet to be fully designed. For example, rapidly growing areas often lack adequate access to regional transportation networks. In Ontario, Metrolinx is unlikely to be unable to extend services to these communities given that their territorial jurisdiction is the GTHA rather than the entire $\mathrm{GGH}$ region. Thus, these types of barriers must be overcome to ensure the necessary infrastructure service provision levels to properly support Growth Plan implementation.

26 The inner ring includes the cities of Toronto, Hamilton and the Regions of Halton, Durham, Peel and York. The outer ring includes the Regions of Niagara and Waterloo; the cities of Barrie, Brantford, Guelph, Kawartha Lakes, Orillia, and Peterborough; and the Counties of Brant, Dufferin, Haldimand, Northumberland, Peterborough, Simcoe, and Wellington (Ministry of Municipal Affairs and Housing, 2019). 
Smart growth policy implementation has also been influenced by some unintended, yet not entirely unanticipated outcomes produced by the Greenbelt Plan. In determining the greenbelt's boundaries, the Liberals made a strategic political decision to leave land outside of the Greenbelt Plan to accommodate future urban development. With approximately 45,000 hectares of land as of 2016, the 'whitebelt' refers to rural areas between the southern boundary of the greenbelt and the outer edge of urban settlement areas adjacent to Lake Ontario (see Figure 5.1). ${ }^{27}$ Designed to relieve growth pressures, this area has fewer restrictions than land protected under the Greenbelt Plan, which can be re-designated as needed for urbanization in local planning processes (Tomalty and Komorowski, 2011). The creation of the whitebelt can be viewed as a political decision by the Liberals to appease developers. By unofficially allocating land for future development, the Liberals were "not going to completely offend the development industry. They will still get to do business somewhat [as] usual for 30, 40, 50 years" (Interview 9). However, there is no immediate need to designate whitebelt lands for development, given the considerable land already approved to accommodate urban growth until 2031 (Neptis Foundation, 2015).

The effect of the challenges of territorial coordination is that greenbelt legislation has apparently facilitated leapfrog development beyond its boundaries into the outer ring municipalities, which is further fuelled by developer-driven politics in these areas (see Figure 5.1). This "displacement of sprawl" is characterized by development 'leaping' over the greenbelt to occur on farmland on the other side (Sturzaker and Mell, 2017, 71). Leapfrog development is problematic because it requires constructing roadways across greenbelts, which increases traffic, fragments natural areas, and undermines the Growth Plan's smart growth approach of encouraging compact communities (Tomalty and Komorowski, 2011). Since the greenbelt's introduction, scholars have warned about the risk of leapfrog development (Fung and Conway, 2007; Pond, 2009). The Greenbelt Plan has stimulated leapfrog development, according to representatives from environmental NGOs, farmers, and local planners (Interviews 2, 5 and 10). However, our findings show that this situation is more complicated. The development industry continues to speculatively buy farmland beyond the greenbelt with a specific segment of this activity driven by foreign companies and pension funds, who pressure landowners to sell their properties resulting in conflicts between residents and agricultural disinvestment (Interview 10). Development companies with large land assemblages can also have considerable influence in persuading local councils to rezone their land to allow the necessary infrastructure to support future developments, highlighting how power dynamics strongly shape territorial politics beyond

27 The whitebelt is not an official term used in provincial policy documents. Officially, all areas outside the Greenbelt and settlement areas are termed agricultural and rural areas (Tomalty and Komorowski, 2011). 
the greenbelt (Interview 10). However, while this land speculation may be common, there is little statistical data to confirm these practices within the region, as governments are not required to keep these records (Tomalty, 2015). Urban sprawl has also been facilitated beyond the greenbelt due to Growth Plan implementation problems such as plan amendments allowing low-density development in Simcoe County, and municipalities adopting minimum intensification targets (ibid.). Thus, while the Greenbelt Plan has been effective in directing development to cities and away from farmland within the greenbelt (Ministry of Municipal Affairs and Housing, 2015), unprecedented growth rates have occurred in some communities such as Simcoe County. This low-density development has led to problems including increased farmland prices (Vyn, 2012) and territorial coordination challenges with regional public service provision (Interview 11). Also, there are conflicts between municipalities regarding paying for the increased maintenance costs associated with higher traffic volumes on regional roadways (Interview 5). While the Liberals launched a consultation on the possibilities for expanding the greenbelt in 2017, the expansion of the greenbelt alone is not enough to address the leapfrogging problem, as the region's growth machine continues to drive development within the GGH's urban fringe.

In connection to leapfrog development, the Greenbelt Plan has become a scapegoat for the development industry, which blames this plan for restricting land supplies due to their fear of escalating housing prices. Developers launched campaigns pressuring provincial politicians to expand urban boundaries ahead of the 2015 policy review (Interview 12). Indeed, international smart growth approaches such as greenbelts and urban growth boundaries highlight the contribution of these policies to increasing land values and housing prices (Dawkins and Nelson, 2002). In the GGH case, however, there is little connection between the Greenbelt and Growth Plans and housing prices. Several factors contribute to regional housing unaffordability including an unbalanced housing stock, supply chain changes, increasing land prices, and shifting demographics (Interview 13). However, as housing prices become unaffordable within the inner ring municipalities, residents seek less expensive housing within the outer ring municipalities, further fuelling leapfrog development. These concerns about housing affordability and leapfrog development show that it is necessary to coordinate smart growth policies between inner and outer ring municipalities to effectively manage these regional growth dynamics. In addition, the issue of leapfrog development, whitebelt lands and housing affordability reflects the Greenbelt Plan impacts communities far beyond the greenbelt's boundaries. These territorial coordination challenges highlight how the GGH region's multi-layered policy structure and overlapping territorialities creates collaboration problems and unintended impacts influencing Greenbelt and Growth Plan implementation. Yet overcoming these problems could be challenging in a region known for its fragmented regional coordination and weak levels of inter-municipal cooperation (Nelles, 2012). 
The outcomes of coordination problems across numerous municipal jurisdictions, policy domains and policy levels are reflected in the GGH region's development patterns. An initial purpose of the Growth Plan was to reduce the rate of regional land consumption compared to past low-density patterns. Indeed, the Neptis Foundation (2015) has found that urban expansion rates have slowed in recent years. However, the results of the first 10 years of Growth Plan implementation show that a large portion of the region's growth is still set to occur in areas not well served by public transit beyond the greenbelt. Without significant changes, the region will continue the problematic suburban development patterns that the "Places to Grow" and Greenbelt legislation were designed to tackle (Burchfield, 2018; 2016).

\subsection{CONCLUSION}

This article explores how the GGH's institutional arrangements influence the governance and implementation of its greenbelt, which has been shaped by vertical, horizontal, and territorial coordination problems. The greenbelt appears to have a functional institutional design with a clear vertical implementation structure managed by the Province and implemented by municipalities. However, further examination reveals institutional coordination challenges. Thus, the policy implementation structure reinforces traditional provincial-municipal relations, yet the Liberals were only willing to relinquish limited control in their efforts to re-engage with regional planning. The lack of a functional regional governance structure for the GGH region has been a persistent problem for decades that would be politically difficult to resolve. With no administrative body specifically responsible for this supra-regional level, the response has been the development of GGH specific policies with overlapping functional and territorial jurisdictions creating difficulties for local implementation. While improvements were made in the 2015 policy review, provincial institutional problems have been downscaled to the local level. Municipal implementation of the Greenbelt and Growth Plans are strongly affected by coordination difficulties with the often-competing policy fields related to greenbelt management, and the significant influence of local growth politics and special purpose bodies. We find that the institutional arrangements safeguarding the greenbelt's protection are vulnerable to shifting political agendas, as weak institutional designs can create opportunities for politics to detract from greenbelt policy goals. Introducing the Greenbelt and Growth Plans represented a tremendous achievement for the Liberals. Indeed, we argue that the institution of this regional planning framework has been positive, rather than allowing traditional land-use planning practices favouring low-density development to continue. However, institutional coordination problems have resulted in uneven greenbelt and smart growth policy implementation, which undermine effective greenbelt management and prevent these policies from delivering the fundamental changes promised by the Liberals' ambitious vision for GGH region. 
Despite these implementation and coordination problems outlined above, we find that our case reflects several best practices for the planning of new generation greenbelts. The GGH greenbelt is supported by strong legislation, a regional growth plan and transportation plan, and its policies are monitored and regularly updated by the Province. Also, organizations such as the Greenbelt Council and the Friends of the Greenbelt Foundation were established by the Province to facilitate policy implementation. These organizations' activities, along with the long-term commitment of civil society groups, have enabled the development of wide public support for the greenbelt. However, the greenbelt's implementation could be further improved, with the following changes being made to the current framework. First, additional initiatives beyond the Greenbelt Plan are needed to support farmers including prioritizing agriculture in planning policies, providing more flexibility with greenbelt policy implementation (Caldwell and Proctor, 2013), and increased training for municipal planning staff about agricultural issues (Interview 7). Also, similar to Burchfield (2018), we argue for the creation of more formal collaboration structures for municipal politicians to address regional issues and partnerships to encourage consensus-building. Finally, the Province could ban or regulate the foreign ownership of farmland and land purchases by pension funds, as has happened in the Canadian provinces of Saskatchewan and Manitoba. Such strategies could restrict some of the land speculation happening beyond the greenbelt, thus reducing suburbanisation pressures on the greenbelt. However, although it might prove difficult to achieve given the current political climate, institutional reforms are needed to achieve more effective Greenbelt and Growth Plan implementation. We argue that a supra-regional agency would have to be created at the GGH level to coordinate regional land-use planning. To avoid the past problems that have afflicted similar agencies such as the Greater Toronto Services Board, this organization would have to be given the appropriate authority to fulfil its mandate.

The case of the GGH greenbelt provides insights for the institutional dimensions and politics of greenbelt governance. Our research indicates that higher level government authorities are seen to be more effective at addressing regional problems and have the institutional capacity and resources to properly support policy implementation (Savitch and Vogel, 2000). However, as greenbelt and smart growth policies require coordination between public and private stakeholders at numerous policy levels, cooperation between these actors is key to effective policy implementation. While local authorities are often responsible for policy implementation, they can contest or even block top-down government interventions (Nelles et al., 2018), highlighting how government interactions significantly shape greenbelt implementation. As the pace of urban sprawl continues almost unabated in most urban regions worldwide, greenbelts are under increasing pressure from local growth politics and land speculation. Indeed, as our case reflects, suburban growth coalitions have a strong impact on greenbelt and smart growth policy implementation, 
reflecting the substantial role that capital accumulation plays in driving development and suburban governance (Ekers et al., 2012). Moreover, it takes years for the effects of greenbelt and other smart growth policies to be seen on the ground; such legislation aims to redirect often deeply ingrained low-density development patterns. Therefore, as Filion and McSpureen (2007) argue, strong institutional structures are needed to ensure smart growth policy implementation over the long-term. In the end though, there is often a difference between smart growth planning ambitions and development practices (Grant, 2009), highlighting the significant impact that politics, institutional coordination problems and competing interests have on new generation greenbelt management.

The power of the Province's authority over land-use planning matters reflects a concern about the institutional design of greenbelt governance, given the vulnerability of these policies to shifting political agendas. This institutional design problem has been seen since the June 2018 election of a new Conservative provincial government under Premier Doug Ford, who has prioritized the greenbelt differently than their predecessors did. In late 2018, legislation was introduced - later retracted due to public protest in January 2019 - which would have allowed for new development within the greenbelt (Gray, January 23, 2019). In June 2019, the More Homes, More Choices Act was approved, which has been criticized for sweeping changes to the province's land-use planning and development system that weakens environmental protections and encourages urban sprawl (Ryerson City Building Institute, 2019). Given the rapid shift in the provincial political regime shown by the Ford Conservative government during its initial months in office, it is difficult to predict what the future of the GGH greenbelt will be. However, the early signs have been very concerning and raise serious questions about the longevity of the greenbelt. After 15 years of stability under a Liberal government, the GGH greenbelt has now reached a critical inflection point in its history. Establishing and implementing a regional greenbelt has taken years of dedicated commitment by multiple stakeholders and it would be a lost opportunity to halt this progress now. The greenbelt is already dealing with significant institutional and governance constraints that influence its implementation. Considering the direct threat by a new provincial political regime, the future of the GGH greenbelt therefore remains highly uncertain. 


\subsection{REFERENCES}

Addie, J. P., \& Keil, R. (2015). Real existing regionalism: The region between talk, territory and technology. International Journal of Urban and Regional Research, 39(2), 407-417.

Allen, R. and Campsie, P. (2013). Implementing the growth plan for the Greater Golden Horseshoe. Has the strategic regional vision been compromised? The Neptis Foundation. Retrieved from http://www.neptis.org/publications/implementing-growth-plan-greater-golden-horseshoe

Amati, M. (Ed.). (2008). Urban green belts in the twenty-first century. Hampshire, England: Ashgate.

Amati, M., \& Taylor, L. (2010). From green belts to green infrastructure. Planning Practice \& Research, 25(2), 143-155.

Amati, M., \& Yokohari, M. (2006). Temporal changes and local variations in the functions of London's green belt. Landscape and Urban Planning, 75(1-2), 125-142.

Brenner, N. (2004). New state spaces: Urban governance and the rescaling of statehood. New York, N.Y.: Oxford University Press.

Briassoulis, H. (2004). The institutional complexity of environmental policy and planning problems: The example of Mediterranean desertification. Journal of Environmental Planning and Management, 47(1), 115-135.

Burchfield, M. (2016). Province must embrace its role as regional planner for growth plan to succeed. The Neptis Foundation. Retrieved from http://www.neptis.org/latest/news/province-mustembrace-its-role-regional-planner-growth-plan-succeed

Burchfield, M. (2018). Bold election ideas for the Toronto region. The Neptis Foundation. Retrieved from http://www.neptis.org/latest/news/bold-election-ideas-toronto-region-0

Caldwell, W. and Proctor, K. (2013). Farming in Ontario's greenbelt: Possibility grows here. Friends of the Greenbelt Foundation. Retrieved from https://www.greenbelt.ca/farming_in_ontario_s_ greenbelt_possibility_grows_here

Campaign Fairness Ontario. (2016). If it's broke, fix it. A report on the money in municipal campaign finances of 2014.

Carter-Whitney, M. (2010). Ontario's greenbelt in an international context. Friends of the Greenbelt Foundation. Retrieved from https://www.greenbelt.ca/ontario_s_greenbelt_in_an_ international_context2010

Côté, A. and Fenn, M. (2014). Provincial-municipal relations in Ontario: Approaching an inflection point. Institute on Municipal Finance and Governance. Retrieved from https://munkschool. utoronto.ca/imfg/uploads/275/1560_imfg_no_17_online_full_colour.pdf

Dawkins, C. J., \& Nelson, A. C. (2002). Urban containment policies and housing prices: An international comparison with implications for future research. Land Use Policy, 19(1), 1-12.

Dierwechter, Y. (2013). Smart growth and state territoriality. Urban Studies, 50(11), 2275-2292.

Ekers, M., Hamel, P., \& Keil, R. (2012). Governing suburbia: Modalities and mechanisms of suburban governance. Regional Studies, 46(3), 405-422.

Filion, P., \& McSpurren, K. (2007). Smart growth and development reality: The difficult co-ordination of land use and transport objectives. Urban Studies, 44(3), 501-523.

Filion, P. (2003). Towards smart growth? The difficult implementation of alternatives to urban dispersion. Canadian Journal of Urban Research, 12(1), 48-70.

Foster, K. A., \& Barnes, W. R. (2012). Reframing regional governance for research and practice. Urban Affairs Review, 48(2), 272-283. 
Friends of the Greenbelt Foundation. (n.d.). About the greenbelt. Retrieved from http://www. greenbelt.ca/about_the_greenbelt

Frisken, F. (2001). The Toronto story: Sober reflections on fifty years of experiments with regional governance. Journal of Urban Affairs, 23(5), 513-541.

Fung, F., \& Conway, T. (2007). Greenbelts as an environmental planning tool: A case study of southern Ontario, Canada. Journal of Environmental Policy and Planning, 9(2), 101-117.

Galland, D. and Harrison, J. (2020). Conceptualising metropolitan regions: How institutions, policies, spatial imaginaries and planning are influencing metropolitan development. In Zimmermann, K., Galland, D. and Harrison, J. (Eds.). Metropolitan regions, planning and governance. (pp. 1-24). Cham, Switzerland: Springer.

Glass, M. R. (2018). Navigating the regionalism-public choice divide in regional studies. Regional Studies, 52(8), 1150-1161.

Grant, J. (2009). Theory and practice in planning the suburbs: Challenges to implementing new urbanism, smart growth, and sustainability principles. Planning Theory \& Practice, 10(1), 11-33.

Gray, J. (November 8, 2018). Planner behind Ontario's greenbelt wins discipline case. The Globe and Mail. Retrieved from https://www.theglobeandmail.com/canada/article-planner-behindontarios-greenbelt-wins-discipline-case/

Gray, J. (January 23, 2019). Ontario reverses course on bill that could have opened greenbelt for development. The Globe and Mail. Retrieved from https://www.theglobeandmail.com/canada/ article-ontario-reverses-course-on-bill-that-could-have-opened-greenbelt-for/

Han, A. T., \& Go, M. H. (2019). Explaining the national variation of land use: A cross-national analysis of greenbelt policy in five countries. Land Use Policy, 81, 644-656.

Hawkins, C. (2014). Competing interests and the political market for smart growth policy. Urban Studies, 51(12), 2503-2522.

Henstra, D. (2017). Local government and politics in Ontario. In Collier, C. and Malloy, J. (Eds.). The politics of Ontario. (pp. 118-134). North York, ON: University of Toronto Press.

Hertel, S. and Markovich, J. (2015). Local leadership matters: Ontario municipalities taking action to strengthen the greenbelt. Friends of the Greenbelt Foundation. Retrieved from https://www. greenbelt.ca/local_leadership_matters_greenbelt2015

Krueger, R., \& Gibbs, D. (2008). 'Third wave' sustainability? Smart growth and regional development in the USA. Regional Studies, 42(9), 1263-1274.

Logan, J.R. and Molotch, H. (1987). Urban fortunes: The political economy of place. Berkeley, CA: University of California Press.

Macdonald, S., \& Keil, R. (2012). The Ontario greenbelt: Shifting the scales of the sustainability fix? The Professional Geographer, 64(1), 125-145.

Mace, A. (2018). The metropolitan green belt, changing an institution. Progress in Planning, 121, 1-28.

March, J. G., \& Olsen, J. P. (2011). Elaborating the "new institutionalism". In Goodin, R. (Ed.). The Oxford handbook of political science. (pp. 159-175). Oxford, England: Oxford University Press.

MacDermid, R. (2006, June). Funding municipal elections in the Toronto region. Paper presented at the Annual General Meetings of the Canadian Political Science Association, Toronto, Canada.

Ministry of Municipal Affairs and Housing. (2015). Performance indicators for the greenbelt plan. Part 1, 2015. Retrieved from http://www.mah.gov.on.ca/AssetFactory.aspx?did=10850

Ministry of Municipal Affairs. (2017). Greenbelt plan, 2017. Retrieved from http://www.mah.gov. on.ca/Page13783.aspx 
Ministry of Municipal Affairs and Housing. (2019). A place to grow. Growth plan for the Greater Golden Horseshoe. Retrieved from https://www. placestogrow.ca/index.php?option=com content\&task=view\&id=9\&Itemid=14

Moore, A. (2013). Planning politics in Toronto: The Ontario municipal board and urban development. Toronto, ON: University of Toronto Press.

More homes, more choices act, 2019. (ON). Schedule 9. (CA). Retrieved from https://www.ontario. ca/laws/statute/s19009

Nelles, J., Gross, J. S., \& Kennedy, L. (2018). The role of governance networks in building metropolitan scale. Territory, Politics, Governance, 6(2), 159-181.

Nelles, J. (2012). Comparative metropolitan policy: Governing beyond local boundaries in the imagined metropolis. London, England: Routledge.

Neptis Foundation (2015). Understanding the fundamentals of the growth plan. Retrieved from http://www.neptis.org/sites/default/files/gp_primer/understanding_the_fundamentals_of_ the_growth_plan_march20_0.pdf

Obeng-Odoom, F. (2012). On the origin, meaning, and evaluation of urban governance. Norsk Geografisk Tidsskrift-Norwegian Journal of Geography, 66(4), 204-212.

Peters, B. G. (2019). Institutional theory in political science: The new institutionalism. (4th ed.) Cheltenham, England: Edward Elgar Publishing.

Pond, D. (2009). Institutions, political economy and land-use policy: Greenbelt politics in Ontario. Environmental Politics, 18(2), 238-256.

Ramirez de la Cruz, E. E. (2009). Local political institutions and smart growth: An empirical study of the politics of compact development. Urban Affairs Review, 45(2), 218-246.

Region of Waterloo. (2015). Ontario municipal board approves new regional official plan. Retrieved from https://www.regionofwaterloo.ca/Modules/News/index.aspx?feedld=928b711d-2b23416c-b47b-b674c929bab6,95abcc5b-2e79-4c15-9386-e36865f55f5a, ab159244-c732-45c7b4c9-67b38b43eed5\&newsld=2f4cacca-9cf4-42c8-90c7-e31de48cb520

Ryerson City Building Institute. (June 10, 2019). Our submission re. bill 108. Retrieved from https:// www.citybuildinginstitute.ca/portfolio/bill-108-analysis/

Sandberg, L. A., Wekerle, G. R., \& Gilbert, L. (2013). The Oak ridges moraine battles: Development, sprawl, and nature conservation in the Toronto region. Toronto, ON: University of Toronto Press.

Savitch, H. V., \& Vogel, R. K. (2000). Introduction: Paths to new regionalism. State and Local Government Review. 32(2). 158-168.

Scott, J. (2007). Smart growth as urban reform: A pragmatic 'recoding' of the new regionalism. Urban Studies, 44(1), 15-35.

Siegel, D. (2009). Ontario. In Sancton, A., \& Young, R. A. (Eds.). Foundations of governance: Municipal government in Canada's provinces. (pp. 20-69). Toronto, ON: University of Toronto Press.

Smart Growth Waterloo Region. (n.d.). About the OMB decision. Retrieved from http:// smartgrowthwaterloo.ca/whats-going-on/about-the-omb-decision/

Sturzaker, J. and I. Mell (2017). Green belts: Past; present; future? New York, NY: Routledge.

Taylor, L. (2019). The future of green belts. In Scott, M., Gallent, N. and Gkartzios, M. (Eds). Routledge companion to rural planning. (pp. 458-468). New York, NY: Routledge.

Taylor, Z. (2013, October). Right-wing populism and the curious revival of regional planning in Toronto. Paper presented at Society for American City and Regional Planning History, Toronto, Canada. 
Tomalty, R. (2015). Farmland at risk: How better land use planning could help ensure a healthy future for agriculture in the Greater Golden Horseshoe. Ontario Federation of Agriculture and Environmental Defense. Retrieved from https://environmentaldefence.ca/2015/11/24/ontariofarmland-at-risk-better-land-use-planning-can-help-save-the-family-farm/

Tomalty, R. and Komorowski, B. (2011). Inside and out: Sustaining Ontario's greenbelt. Friends of the Greenbelt Foundation. Retrieved from http://www.greenbelt.ca/inside_and_out_sustaining ontario_s_greenbelt2011

Vyn, R. J. (2012). Examining for evidence of the leapfrog effect in the context of strict agricultural zoning. Land Economics, 88(3), 457-477.

Wekerle, G., Sandberg, A., Gilbert, L. and Binstock, M. (2007). Nature as a cornerstone of growth: Regional and ecosystems planning in the Greater Golden Horseshoe. Canadian Journal of Urban Research, 16(1): 20-38.

White, R. (2007). The growth plan for the Greater Golden Horseshoe in historical perspective. The Neptis Foundation. Retrieved from http://www.neptis.org/publications/growth-plan-greatergolden-horseshoe-historical-perspective

Willi, Y., Pütz, M., \& Müller, M. (2018). Towards a versatile and multidimensional framework to analyse regional governance. Environment and Planning C: Politics and Space, 36(5), 775-795.

Young, O. R. (2002). The institutional dimensions of environmental change: Fit, interplay, and scale. London, England: MIT Press.

Young, O. R., King, L. A., Schroeder, H., Galaz, V., \& Hahn, T. (2008). Institutions and environmental change: Principal findings, applications, and research frontiers. Cambridge, MA: MIT Press. 


\subsection{APPENDIX: CITED INTERVIEWS}

\begin{tabular}{|c|c|c|c|}
\hline Interview No. & Position Title & Organization & Date \\
\hline 1 & Professor & GGH Region University & November 8, 2018 \\
\hline 2 & Municipal Politician & GGH Region Municipality & August 20, 2014 \\
\hline 3 & Manager & $\begin{array}{l}\text { Environmental Non- } \\
\text { governmental } \\
\text { Organization }\end{array}$ & October 17, 2017 \\
\hline 4 & Planner & $\begin{array}{l}\text { Ministry of Municipal } \\
\text { Affairs and Housing, Ontario } \\
\text { Government }\end{array}$ & August 29, 2018 \\
\hline 5 & Community Planner & GGH Region Municipality & November 5, 2018 \\
\hline 6 & Two Senior Planners & $\begin{array}{l}\text { Ministry of Municipal } \\
\text { Affairs and Housing, Ontario } \\
\text { Government }\end{array}$ & October 16, 2017 \\
\hline 7 & Senior Officer & $\begin{array}{l}\text { Farming Non-governmental } \\
\text { Organization }\end{array}$ & November 12,2014 \\
\hline 8 & Planner & $\begin{array}{l}\text { Ministry of Municipal } \\
\text { Affairs and Housing, Ontario } \\
\text { Government }\end{array}$ & January 28, 2019 \\
\hline 9 & Two Planners & $\begin{array}{l}\text { GGH region Conservation } \\
\text { Authority }\end{array}$ & August 27, 2014 \\
\hline 10 & Environmental Activist & & August 19, 2014 \\
\hline 11 & $\begin{array}{l}\text { Environmental } \\
\text { Consultant }\end{array}$ & & April 2, 2019 \\
\hline 12 & Senior Official & Environmental Foundation & October 10, 2017 \\
\hline 13 & Manager & Home Builders Association & October 13, 2017 \\
\hline
\end{tabular}





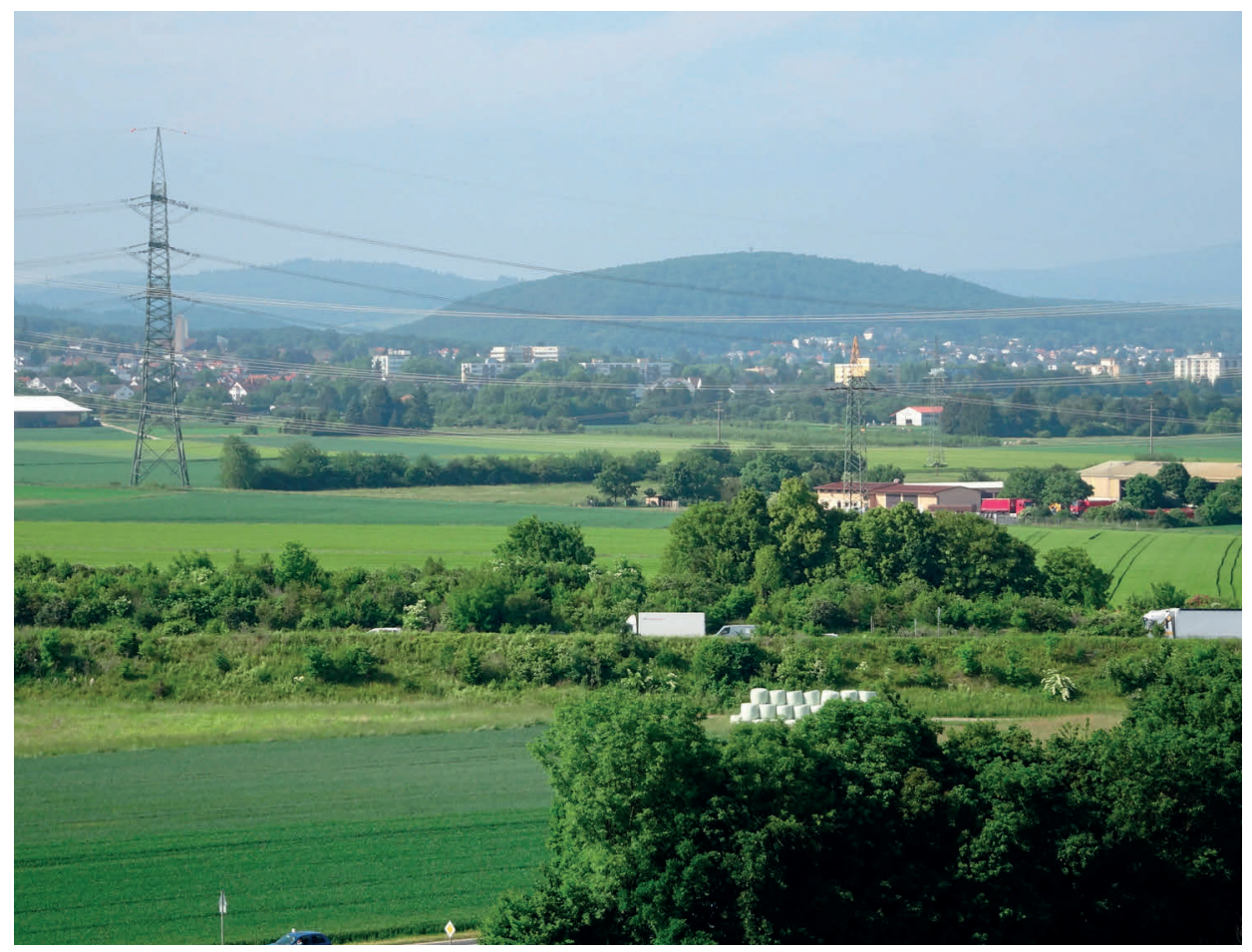

View from the Regionalpark Visitor Centre, Flörsheim am Main (2018). Source: author 


\section{Re-thinking the governance and planning of a new generation of greenbelts}

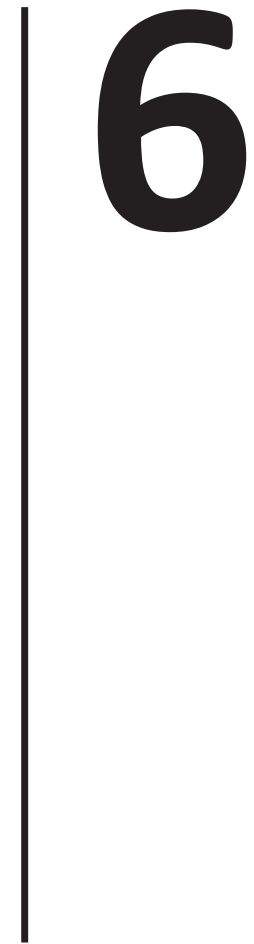

Published as Macdonald, S., Monstadt, J., \& Friendly, A. (2020). Rethinking the governance and planning of a new generation of greenbelts. Regional Studies (forthcoming special issue "Regional planning: interests, institutions and relations"), Doi: 10.1080/00343404.2020.1747608 


\section{ABSTRACT}

In recent decades, a new generation of greenbelts has developed that are embedded within dynamic regionalism processes. Governing these greenbelts is increasingly challenged by institutional arrangements requiring coordination across multiple policy fields, territorial jurisdictions, and policy levels - complexities that are not yet reflected within the literature. Thus, we explore how vertical, horizontal, and territorial coordination problems shape the development of greenbelts in Southern Ontario and the Frankfurt region. We conclude that regional greenbelts need new policy approaches and institutional reforms to manage the governance challenges facing this new generation of greenbelts.

\section{Keywords}

greenbelts, regional governance, institutions, Greater Golden Horseshoe region, Frankfurt Rhine-Main region. 


\subsection{INTRODUCTION}

The greenbelt concept has evolved since its introduction more than a century ago taking on new meanings, influenced by evolving planning discourses. Greenbelt policies from the late $19^{\text {th }}$ and early $20^{\text {th }}$ centuries were based on an industrial heritage and created city-hinterland divisions. The greenbelt concept spread internationally from England after World War II and cities implemented these policies with diverse results (Han and Go, 2019; Sturzaker and Mell, 2017). In recent decades, a new generation of greenbelts has emerged. Contemporary greenbelt policies often address regionalised suburbanisation and pursue multi-functional policy goals including economic development, nature protection and growth containment. Similarly, as the greenbelt concept has shifted, regional governance structures have evolved in recent decades faced with territorial competition and state deregulation (Keil et al., 2017). These co-evolving trends and societal shifts create new challenges to govern greenbelts and raise questions about how to best manage greenbelts in today's changing urban regions.

As greenbelt policies have become more ambitious in addressing multiple policy goals and reaching far into urban regions, we argue that greenbelts are now implanted into complex regional governance arrangements shaping wider socio-spatial relationships. However, managing regional greenbelts involves considerable institutional complexities and governance challenges. Greenbelt policy implementation requires coordination across several policy fields such as housing, farming, and nature conservation (horizontal coordination), across numerous policy levels (vertical coordination) and multiple administrative jurisdictions (territorial coordination). Being situated within these increasingly complex institutional environments raises questions about whether new generation greenbelt policies can deliver on their promises.

Greenbelt policies inherited from previous eras are partially seen as anachronistic and in response, alternative greenspace protection models such as green infrastructure have become popular (Lennon, 2015; Sturzaker and Mell, 2017). Recent greenbelt approaches often involve flexible governance arrangements with actors from multiple sectors and territorial jurisdictions. Yet, the institutional complexities and governance challenges involved in managing new generation greenbelts are not well reflected within the literature. To explore the challenges involved in regional greenbelt governance, we selected two examples of greenbelts in Southern Ontario (Canada) and the Frankfurt Rhine-Main region (Germany). Both greenbelts were established within the past 25 years under different governance models. Ontario's Greater Golden Horseshoe (GGH) greenbelt policies reflect a top-down approach, while the Frankfurt Rhine-Main greenbelt is managed by a publicprivate partnership. Comparing these greenbelts' different institutional designs allows 
for an examination of the governance challenges involved in greenbelt management under different institutional settings. In this article, we analyse how the institutional and governance arrangements in Southern Ontario and the Frankfurt region impact greenbelt management. We ask: How is greenbelt implementation in both regions coordinated across numerous territorial jurisdictions, policy domains and policy levels and how could it be more effectively governed?

This article is organized as follows: first, the methodology section outlines the case study selection rationale. Then we review greenbelt debates from a governance and institutional perspective and discuss the conceptual framework being applied to this research. This is followed by an overview of the GGH and Frankfurt regions and their respective greenbelts. Finally, we discuss the governance challenges of managing both greenbelts, structured along the dimensions of vertical, horizontal, and territorial coordination. Through a comparative analysis of our cases, we find that the GGH greenbelt policies have effectively halted growth within the greenbelt yet have encouraged leapfrog development. The RhineMain region's greenbelt policies have stimulated tourism promotion but hardly provide an effective mechanism for growth containment. Thus, we conclude that while the GGH greenbelt has been more effective in achieving more ambitious policy goals, both cases have mixed outcomes.

\subsection{RESEARCH METHODOLOGY}

This research responds to calls for comparison across diverse urban contexts (Robinson, 2011). Based upon a literature review, it builds a typology of greenbelt planning signalling a shift from traditional models from the late $19^{\text {th }}$ century to a new generation of greenbelts. This article focuses on a 15-year time period (2003-2018) in the GGH region under a provincial Liberal government. The Frankfurt case reflects a similar timeframe (2005-2018), beginning with the establishment of a regional greenbelt agency—the Regionalpark Ballungsraum Rhein-Main $\mathrm{GmbH}$. The empirical research is based on 79 interviews: 42 within the GGH region (August 2014 - June 2019) and 37 within the Frankfurt Rhine-Main region (September 2017 - July 2019). Interviews were held with representatives from municipal, regional, and provincial governments, environmental activists, farmers, and academics. Interview participants were selected to include major stakeholder groups responsible for greenbelt management. The interviews focused on how greenbelt implementation has been coordinated across multiple policy levels, stakeholders, and municipalities. This was complemented by a review of government policy documents and non-governmental organization reports from both cases. Using our conceptual framework, the interview transcripts were analysed to identify how each case's institutional environment impacts greenbelt implementation. 
The case study selection rationale was that the GGH greenbelt and Frankfurt's regional greenbelt, the Regionalpark RheinMain, share various commonalities. Both are examples of the new generation of greenbelts: they have a regional scope, their policies are set by provincial or state governments, and their implementation requires coordination between numerous stakeholders in various policy domains, at multiple policy levels and across municipalities. However, these cases exhibit different institutional designs of greenbelt management (see above). By comparing the different institutional arrangements, we reflect on governance challenges involved in greenbelt implementation.

\subsection{THE EVOLUTION OF GREENBELTS: FROM TRADITIONAL MODELS TO A NEW GENERATION OF GREENBELTS}

Greenbelts are one of the most well-known planning approaches to control urban growth. Their purposes and governance complexities have evolved since their origin over a century ago (Table 6.1) ${ }^{28}$. While the greenbelt concept is associated with numerous greenspace projects in the late $19^{\text {th }}$ and early $20^{\text {th }}$ centuries, greenbelts are most strongly connected to UK planning and the Garden City idea (Freestone, 2002). Traditional greenbelts were developed before World War II in response to problems associated with industrialization, largely implemented in top-down planning systems. Introduced by national or local governments, traditional greenbelt policies were designed to protect farmland, provide greenspaces for urban residents, and reinforce city-countryside divisions (Sturzaker and Mell, 2017). However, this top-down approach creates challenges as municipalities often take discretion in applying higher-level government policies, resulting in inconsistent greenbelt implementation.

Following World War II until the late 1970s, the greenbelt concept reached peak popularity in planning discourses, spreading internationally based on the UK model. Modernist greenbelts diverged from their traditional counterparts as cities adapted greenbelt policies to their needs, resulting in multiple spatial forms and diverse policy goals (Amati, 2008). However, compared to the previous period, greenbelts established after 1945 often displayed a restrictive planning approach with their main purpose being urban growth containment (Hall, 2007). Greenbelt policies adopted during the early post World War II years reflected modernist planning principles, based on an assumption that other

28 This table distinguishes between three types of greenbelts that are characteristic for a specific period. However, these are ideal types and traditional or modernist greenbelts could be developed today. 
jurisdictions could apply the greenbelt model as effectively as in England (Amati, 2008). However, international greenbelt examples achieved mixed results (Han and Go, 2019). The traditional top-down approach evolved during this time to include increased state and regional government involvement and more decentralized governance models, including increasing civil society influence on greenbelt planning. Also, during this period, planning de-regulation forced some governments to alter their greenbelt policies (Amati, 2008).

Since the 1990s, a new generation of greenbelts has emerged, with the greenbelt concept being rethought to reflect more complex thinking about urban regions. Traditional postWWII suburbs have evolved towards regionalised in-between cities (Sieverts, 2003) or post-suburban forms of regional urbanization (Phelps and $\mathrm{Wu}, 2011$ ), requiring new governance arrangements (Hamel and Keil, 2015). Reflecting the shifts in urban regions in recent decades (Paasi and Metzger, 2017), greenbelts are now embedded within regionalised suburban landscapes, reflected in adaptations to greenbelt planning. While this new generation of greenbelts continues to pursue policy goals such as urban growth containment and farmland protection, they go beyond their modernist predecessors to include new objectives such as providing eco-system services, contributing to economic development and climate mitigation and adaptation. Also, given the popularity of smart growth planning principles, greenbelts are now key components of integrated land-use planning frameworks that are designed to better manage regional development (Filion and McSpurren, 2007; Macdonald and Keil, 2012). However, the larger number of policy fields incorporated into greenbelt policies increases the number of stakeholders at multiple policy levels involved in policy implementation, subsequently increasing the governance complexities involved in their management. Compared to modernist greenbelts, however, these recent greenbelts often have flexible governance approaches, with less higher-level government involvement and an increased role of special purpose bodies and NGOs in greenbelt management, reflecting current environmental planning trends. 
Table 6.1: Typology of Greenbelts

\begin{tabular}{|c|c|c|c|}
\hline Characteristic & Traditional greenbelts & Modernist greenbelts & New Generation Greenbelts \\
\hline Time period & Pre-World War II & 1945 to late $1980 \mathrm{~s}$ & 1990s to the present \\
\hline Examples & $\begin{array}{l}\text { London, Vienna, } \\
\text { Berlin, Paris }\end{array}$ & $\begin{array}{l}\text { Melbourne, Randstad, } \\
\text { Copenhagen }\end{array}$ & $\begin{array}{l}\text { Greater Golden Horseshoe, } \\
\text { Frankfurt Rhine-Main, São } \\
\text { Paulo }\end{array}$ \\
\hline Context & $\begin{array}{l}\text { Unhealthy cities, } \\
\text { industrialization, } \\
\text { urbanization }\end{array}$ & $\begin{array}{l}\text { Rapid urbanization, } \\
\text { participatory } \\
\text { planning approaches, } \\
\text { environmental } \\
\text { movements }\end{array}$ & $\begin{array}{l}\text { Globalisation, } \\
\text { suburbanisation, } \\
\text { regionalisation, sustainable } \\
\text { development, state } \\
\text { de-regulation }\end{array}$ \\
\hline $\begin{array}{l}\text { Institutional } \\
\text { design }\end{array}$ & $\begin{array}{l}\text { Top-down government } \\
\text { approach }\end{array}$ & $\begin{array}{l}\text { Top-down government } \\
\text { approaches or de- } \\
\text { centralized governance } \\
\text { models }\end{array}$ & $\begin{array}{l}\text { More flexible governance } \\
\text { approaches }\end{array}$ \\
\hline Policy goals & $\begin{array}{l}\text { City-countryside } \\
\text { separation, farmland } \\
\text { preservation, open } \\
\text { spaces for urban } \\
\text { residents }\end{array}$ & $\begin{array}{l}\text { Urban growth } \\
\text { containment, nature } \\
\text { conservation, farmland } \\
\text { protection, recreational } \\
\text { spaces }\end{array}$ & $\begin{array}{l}\text { Multi-purpose: adding } \\
\text { climate mitigation/ } \\
\text { adaptation, economic } \\
\text { development, ecosystem } \\
\text { services, regional identity to } \\
\text { earlier goals }\end{array}$ \\
\hline Spatial scope & $\begin{array}{l}\text { Ring of greenspace } \\
\text { around a city }\end{array}$ & Variety of spatial forms & $\begin{array}{l}\text { Functional scope to address } \\
\text { regional suburbanisation }\end{array}$ \\
\hline $\begin{array}{l}\text { Relevant } \\
\text { stakeholders }\end{array}$ & $\begin{array}{l}\text { National \& local } \\
\text { governments, } \\
\text { landowners, planners, } \\
\text { general public }\end{array}$ & $\begin{array}{l}\text { Same as traditional } \\
\text { greenbelts, but } \\
\text { increasing role of state/ } \\
\text { regional governments, } \\
\text { civil society }\end{array}$ & $\begin{array}{l}\text { Same as modernist } \\
\text { greenbelts, but increasing } \\
\text { role of special purpose } \\
\text { bodies, non-governmental } \\
\text { organizations (NGOs), public- } \\
\text { private partnerships (PPPs) }\end{array}$ \\
\hline $\begin{array}{l}\text { Governance } \\
\text { complexities }\end{array}$ & $\begin{array}{l}\text { Government } \\
\text { policy creation \& } \\
\text { implementation. } \\
\text { Vertical coordination: } \\
\text { Municipal discretion in } \\
\text { applying higher-level } \\
\text { government policies } \\
\text { resulted in uneven } \\
\text { applications. }\end{array}$ & $\begin{array}{l}\text { Horizontal } \\
\text { coordination: } \\
\text { Landowner resistance } \\
\text { to greenbelts. } \\
\text { Vertical coordination: } \\
\text { Planning de-regulation } \\
\text { undermined greenbelt } \\
\text { implementation. }\end{array}$ & $\begin{array}{l}\text { Horizontal coordination: } \\
\text { Increased role of special } \\
\text { purpose bodies, NGOs, PPPs. } \\
\text { Horizontal coordination: } \\
\text { Increased policy multi- } \\
\text { functionality expands } \\
\text { number of actors \& policy } \\
\text { fields involved. Territorial } \\
\text { coordination: multiple } \\
\text { municipalities involved } \\
\text { in regional greenbelt } \\
\text { management. }\end{array}$ \\
\hline
\end{tabular}

Source: own figure based on Amati, 2008; Amati and Taylor, 2010; Carter-Whitney, 2010; Freestone, 2002; Sturzaker and Mell, 2017. 


\subsection{THE INSTITUTIONAL DIMENSIONS OF THE GOVERNANCE OF REGIONAL GREENBELTS}

As the new generation of greenbelts often cross administrative boundaries and are shaped by multiple stakeholders, we argue that applying a regional governance lens is necessary for analysing regional greenbelt implementation. Greenbelt development has evolved as the state itself has reorganized (Jessop, 2000) and traditional forms of spatial planning led by municipalities prove insufficient to tackle complex public responsibilities. Similar to other regional development processes, the governance of regional greenbelts happens through "network-like coordination [...] processes and comprises vertical and horizontal coordination of state and non-state actors in a functional space" (Willi et al., $2018,12)$. Greenbelt decision-making also increasingly involves civil society groups and special purpose bodies, reflecting recent trends to delegate public service provision to the private sector (Stoker, 1998). New generation greenbelts are often regional in spatial scope, thus involving multiple municipal and regional jurisdictions. While greenbelts are now embedded within these complex governance and institutional structures, these greenspaces are not highlighted within regional governance debates. Some literature explores the regionalism of greenbelts (Addie and Keil, 2015; Macdonald and Keil, 2012). However, the institutional challenges of regional governance are often not addressed, with some exceptions (Röhring and Gailing, 2005). Some literature compares greenbelt practices in several countries (Amati, 2008; Carter-Whitney, 2010), yet these hardly analyse the institutional dimensions of greenbelt governance.

As greenbelt development reflects the institutional environments in which they were established (Pond, 2009), we argue that an institutional perspective is needed to understand greenbelt governance. Han and Go (2019) find that institutional structures play a key role in shaping greenbelt policies and determine the greenbelt governance model applied in each case. The types of planning regulations available to establish a greenbelt such as a designation or zone depend on that location's land-use planning regime, contributing to the variation seen in international greenbelt examples (L. Taylor, 2019). Greenbelt governance is structured by institutions, which we define as rules and practices embedded within structures of meaning that are fairly resistant to changing circumstances (March and Olsen, 2011). Institutions thus enable and constrain actors, distribute power relations, create order, and represent the structures necessary for governing processes (ibid. ${ }^{29}$. The main institutional perspectives within the literature

29 Within institutionalism, a distinction is made between formal and informal institutions. Formal institutions include constitutions, laws and regulations, while informal institutions include traditions and conventions (Hall and Taylor, 1996). 
includes historical institutionalism, rational choice institutionalism and sociological institutionalism (see Peters, 2019; Lowndes, 2010), with each approach explaining processes of institutional stability and change, and the interaction between institutions and individuals in change processes (Hall and Taylor, 1996). Within urban and regional governance debates, institutions are viewed as essential for spatial development, as the design of institutions structures the governance of cities and regions and defines urbanization and suburbanisation (Z. Taylor, 2019). There is discussion within the literature about how to best govern urban regions, with prominent institutional approaches including the metropolitan reform school, the public choice model and new regionalism (see Glass, 2018; Nelles, 2012). Apart from these different approaches to institutional reforms in regional governance, academic debates have also addressed alleged shifts away from formal institutional frameworks towards more flexible, soft spaces of governance (Allmendinger and Houghton, 2009). Once established, urban and regional planning institutions are often resistant to change or develop in a path dependent way. Given their longevity and path dependency, institutional arrangements in greenbelt governance can impact stakeholders' behaviour who anticipate the continuance of greenbelt institutions, adjusting their actions accordingly (Mace, 2018).

By applying an institutional perspective to greenbelt planning, we introduce three institutional dimensions influencing the effectiveness of regional greenbelt governance: vertical, horizontal, and territorial coordination ${ }^{30}$. A key concern impacting greenbelt management is the vertical coordination of greenbelt policies between stakeholders at multiple policy levels (e.g. municipal, regional, provincial, or state). Greenbelt policies often have a vertical institutional design where legislation is set by higher levels of government and its implementation is overseen by lower level authorities, resulting in coordination challenges (Carter-Whitney, 2010). How greenbelt policies are framed by senior government authorities is important, as it structures local stakeholders' responses to these policies (Han and Go, 2019).

At the same time, effective greenbelt management necessitates horizontal coordination across multiple policy domains at the same level-nature conservation, agriculture, and housing - with the private sector and civil society actors shaping those domains. Greenbelt implementation is often influenced by dominant groups such as developers, causing politics and stakeholders' self-interests to impact policy outcomes (Cadieux et al., 2013).

Finally, regional greenbelt management requires territorial coordination across multiple

30 For similar analytical categories see: Röhring and Gailing, 2005; Young, 2002. 
municipalities. However, administrative jurisdictions rarely match a greenbelt's spatial scope, resulting in institutional "misfits" and coordination problems (Young, 2002). Local authorities often take discretion in greenbelt policy application, resulting in uneven greenbelt implementation. Bringing together these three forms of institutional coordination allows for an analysis of the institutional complexities of greenbelt governance to examine the difficulties of new generation greenbelt management, which will be discussed later in the article.

\subsection{TWO DIFFERENT INSTITUTIONAL MODELS OF REGIONAL GREENBELT PLANNING}

This section provides an overview the GGH and the Frankfurt Rhine-Main regions' institutional contexts and their greenbelts. These two regions share geographical and governance similarities to anchor this comparative research. Both global city regions are financial centres, characterized by strong demographic growth and regionalised suburbanisation (Keil et al., 2017). These regions also share common governance characteristics including being in a federal country, a history of contentious institutional reforms and fragmented public service provision (Nelles, 2012). However, these regions also differ in institutional features: Ontario has a two-tiered government structure between the provincial government and municipalities, while the Frankfurt region's institutions include municipalities, inter-municipal authorities at various regional scales and a twotiered state government (Land). As outlined below, both regions have adopted regional greenbelts in recent decades, while each has pursued different approaches to achieve its policy goals.

\subsubsection{The GGH Greenbelt: A top-down approach to greenbelt planning}

As Ontario's economic engine, the GGH region covers approximately $32,000 \mathrm{~km}^{2}$ and includes large cities, towns and rural areas including 110 municipalities (Figure 6.1) (Allen and Campsie, 2013). In 2016, the GGH had a population of 9 million, which is expected to grow to 13.48 million residents by 2041 (Ministry of Municipal Affairs and Housing, 2019). The GGH has complex institutional structures including the Ontario provincial government, a municipal level divided between upper, lower, and single-tier municipalities and numerous special purpose organizations. 


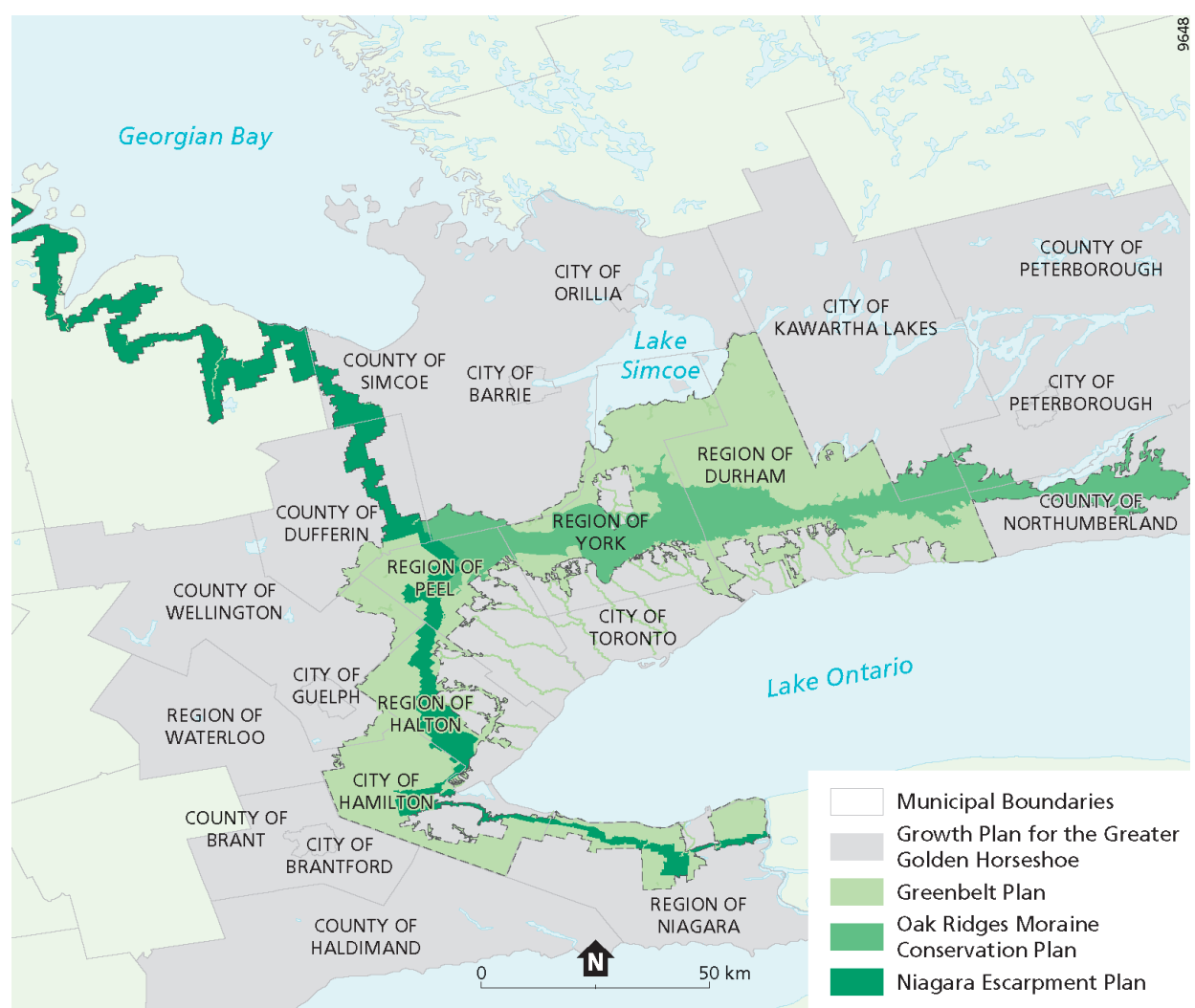

Figure 6.1: The Greater Golden Horseshoe Region

Source: Ministry of Municipal Affairs and Housing, 2019; Ministry of Municipal Affairs, 2017

The greenbelt is part of an ambitious regional planning framework introduced by a Liberal provincial government (2003-2018) designed to rethink how residents live and work within the GGH for future generations. The greenbelt legislation went far beyond traditional greenbelt policy goals: as a state spatial strategy, it generated new forms of regional governance (Macdonald and Keil, 2012). In 2005, the Greenbelt Act passed by the provincial government (referred to herein as the Province) allowed for the creation of a Greenbelt Plan, also released that year. Spanning approximately $7,200 \mathrm{~km}^{2}$ across the GGH, the greenbelt's policy goals include protecting farmland and environmentally sensitive areas, providing recreational spaces, and mitigating and adapting to climate change (Ministry of Municipal Affairs, 2017). Billed as the largest permanently protected greenbelt in the world, the GGH greenbelt contains some of Canada's most productive farmland. Building upon nature conservation areas such as the Oak Ridges Moraine and the Niagara Escarpment, the greenbelt's primary land-uses include agriculture, a natural heritage system and rural settlement areas. The Province created two organizations to 
support policy implementation: firstly, the Greenbelt Council comprised of stakeholders that provide advice to government about plan implementation and secondly, the Friends of the Greenbelt Foundation promote the greenbelt through educational activities. Because the greenbelt has a vast territorial scope and includes multiple land-uses, the Greenbelt Plan intersects with several provincial plans and policies from conservation authorities, municipalities, and the federal government. Thus, the Greenbelt Plan is read in conjunction with other policies related to agriculture, nature conservation, and infrastructure, resulting in its implementation being influenced by a complex policy environment involving stakeholders at numerous policy levels. When it was introduced, the Greenbelt Plan was contested, as farmers, developers and municipalities resented the development restrictions imposed by the plan. Over time however, many of these stakeholders' original concerns have shifted to the acceptance of the Greenbelt Plan, reflecting the now wide public support for these policies (Interviews 1 and 2).

The Greenbelt Plan was designed together with the "Places to Grow" legislation to manage regional development. The greenbelt creates an urban containment boundary, with the Growth Plan directing development into built-up areas. The Places to Grow Act allowed for the preparation of growth plans, and in 2006 the first plan for the GGH was released. This 25-year growth plan was designed to manage regional growth until 2031 (which was extended until 2041), secure economic prosperity and encourage urban intensification (Ministry of Municipal Affairs and Housing, 2019). The Greenbelt and Growth Plans are to be reviewed by the provincial Ministry of Municipal Affairs and Housing every 10 years to assess their effectiveness, and revised versions of these plans were released in 2017. During this review process is the only time that the Minister of Municipal Affairs and Housing can make amendments to the greenbelt's protected areas. However, these changes cannot decrease the greenbelt's total area (Ministry of Municipal Affairs, 2017).

The Greenbelt and Growth Plans rely on an institutional design based on a vertical hierarchical structure, reflecting Ontario's provincially led land-use planning system (Table 6.2). The Province sets the direction for land-use planning through the Planning Act and the Provincial Policy Statement. In certain areas of Ontario, there are provincial plans that have more detailed policies such as the Greenbelt Plan. Municipalities are then responsible for implementing provincial policies through their official plans and must make their planning decisions conform with provincial interests. However, if there are disagreements regarding local planning decisions, then appeals can be made to the Local Planning Appeal Tribunal (LPAT). The LPAT is a provincially appointed tribunal that makes decisions regarding municipal land-use planning matters, providing an important dispute resolution mechanism in the land-use planning system. Thus, Ontario's greenbelt policies display a 
top-down approach to greenbelt planning, with its implementation being impacted by provincial-municipal relations and coordination problems between local stakeholders, which will be explored later in the article.

Table 6.2: Ontario's Land-Use Planning System

\begin{tabular}{lll}
\hline Authorities & Legislation and Policies & $\begin{array}{l}\text { Spatial Scope of } \\
\text { Legislation \& Policies }\end{array}$ \\
\hline Ontario Government & $\begin{array}{l}\text { The Planning Act, Provincial Policy Statement } \\
\text { (PPS) }\end{array}$ & $\begin{array}{l}\text { Province of Ontario } \\
\text { Ontario Government }\end{array}$ \\
& $\begin{array}{l}\text { GGH Growth Plan, Greenbelt Plan, } \\
\text { Oak Ridges Moraine Conservation Plan, } \\
\text { Niagara Escarpment Plan }\end{array}$ & $\begin{array}{l}\text { Specific parts of the } \\
\text { Province of Ontario }\end{array}$ \\
\hline Municipalities & $\begin{array}{l}\text { Official Plans, Zoning } \\
\text { By-laws, Site Plans* }\end{array}$ & Municipal \\
\hline
\end{tabular}

*Municipal decisions related to these policies are subject to the Local Planning Appeal Tribunal. Source: author

\subsubsection{The Regionalpark RheinMain: A decentralized model of greenbelt planning}

The Frankfurt Rhine-Main region is embedded within a complex institutional structure. At its core lies the Greater Frankfurt region which is a politically defined territory of a network of urban centres, and towns with the city of Frankfurt as its largest urban node. It includes 2.34 million residents and 75 municipalities (Regionalverband, 2018). In this suburbanized region, municipal land-use planning has been upscaled to the level of the Regional Authority Frankfurt RheinMain. The Greater Frankfurt Area is the urbanized core of the larger Frankfurt Rhine-Main Metropolitan region, which has 5.7 million inhabitants and stretches over three federal states (Länder) (ibid.) (Figure 6.2). Greater Frankfurt has experienced strong population growth in recent years and is predicted to grow by 191,000 residents by 2030 (ibid.). It is known as a transportation hub, a global financial centre and is shaped by strong functional interdependencies between its core cities and their surrounding region.

Regional greenspace management in Greater Frankfurt is influenced by complex institutional structures and partially overlapping spatial planning authorities at the municipal, inter-municipal, regional and Länder level, by specific institutional arrangements in nature conservation and by multiple special purpose bodies (Table 6.3). 


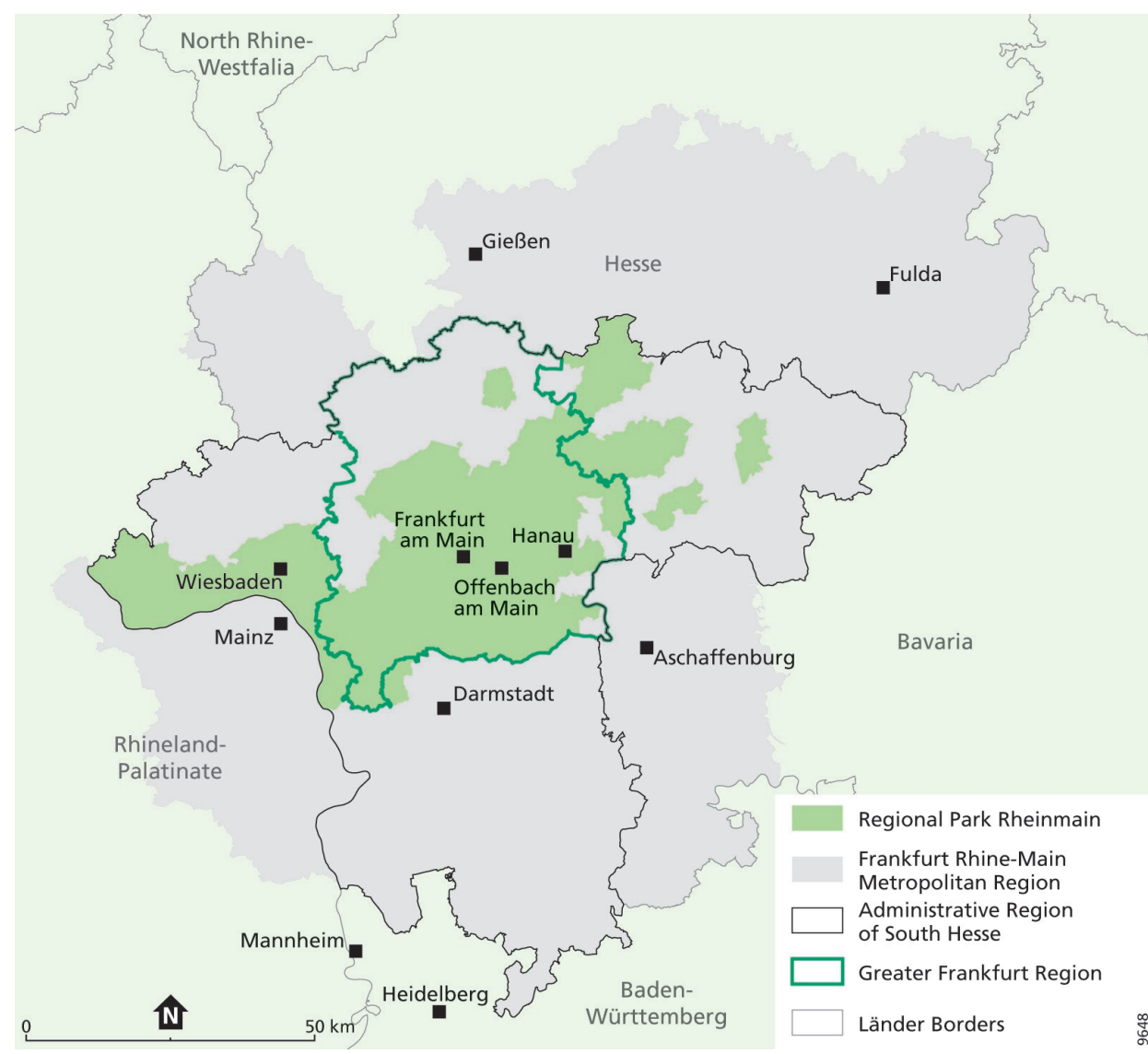

Figure 6.2: The Frankfurt Rhine-Main Metropolitan Region and the Greater Frankfurt Region

Source: Regionalverband, 2018

In Germany's federal system, the main institutional resources, and operational tasks in spatial planning rest with the Länder and the municipalities. In line with the "counterflow principle", each level is responsible for planning on its level, but must consider or integrate plans of the super- and subordinate levels. It thus combines top-down and bottom-up approaches. In Hesse, a Länder development plan (Landesentwicklungsplan) sets general objectives, which are then specified in the regional plan for South Hesse (Regionalplan). Municipalities exercise their constitutional right to planning by preparing a two-tier system of land-use plans: a (preparatory) land-use plan outlining all types of land-uses for the municipality and legally binding zoning plans for settlement areas that regulate the amount and type of building activity. Apart from six cities in the Ruhr region, Greater Frankfurt is the only German region where a regionalised land-use plan (regionaler Flächennutzungsplan) has been adopted. The Regional Authority (Regionalverband FrankfurtRheinMain), 
which is responsible for development in the whole metropolitan region, prepares such a regionalised land-use plan for its urban core, i.e. its 75 member municipalities in Greater Frankfurt. Both the regionalised land-use plan as well as the regional plan prioritize the confinement of development along growth corridors and within existing urban areas, greenspace preservation and the Regionalpark RheinMain's expansion (Regionalverband, 2010). However, as continuing suburban growth demonstrates, planning goals to contain peripheral growth can be undermined by municipalities seeking to boost tax revenues by attracting investment in local development (Monstadt and Meilinger, 2020).

Table 6.3: The Spatial Planning System in the Frankfurt Rhine-Main Region

\begin{tabular}{|c|c|c|}
\hline $\begin{array}{l}\text { Administrative } \\
\text { Level }\end{array}$ & Authorities/Agencies & $\begin{array}{l}\text { Legislation and Policies in } \\
\text { Spatial Planning }\end{array}$ \\
\hline Federal & Federal Government & $\begin{array}{l}\text { Principles and strategic visions, } \\
\text { Federal Spatial Planning Act, } \\
\text { Federal Building Code }\end{array}$ \\
\hline $\begin{array}{l}\text { State of Hesse } \\
\text { (Land Hessen) }\end{array}$ & $\begin{array}{l}\text { Spatial Planning Authority of } \\
\text { the State of Hesse }\end{array}$ & $\begin{array}{l}\text { Hessian State Planning Act, } \\
\text { State Development Plan (Lan- } \\
\text { desentwicklungsplan), } \\
\text { Law on the Metropolitan Regi- } \\
\text { on Frankfurt/Rhine-Main }\end{array}$ \\
\hline $\begin{array}{l}\text { Region of South } \\
\text { Hesse }\end{array}$ & $\begin{array}{l}\text { Regional Planning Authority for } \\
\text { South Hesse (Regierungspräsi- } \\
\text { dium Darmstadt) }\end{array}$ & $\begin{array}{l}\text { Regional plan for South Hesse } \\
\text { (Regionalplan)* }\end{array}$ \\
\hline $\begin{array}{l}\text { Inter-municipal: } \\
\text { Greater Frankfurt } \\
\text { Region }\end{array}$ & $\begin{array}{l}\text { Regional Authority } \\
\text { (Regionalverband Frankfurt- } \\
\text { RheinMain) }\end{array}$ & $\begin{array}{l}\text { Greater Frankfurt regionalised } \\
\text { land-use plan (regionaler Flä- } \\
\text { chennutzungsplan) }\end{array}$ \\
\hline Municipal & $\begin{array}{l}\text { Municipal administrations } \\
\text { (Kommunalverwaltungen) }\end{array}$ & $\begin{array}{l}\text { Local land-use plans (except for } \\
\text { the Greater Frankfurt region) } \\
\text { and zoning plans (Bebauungs- } \\
\text { pläne) }\end{array}$ \\
\hline
\end{tabular}

*The regional plan and the regionalised land-use plan are combined in one document in this case.

Source: author

The spatial plans at the different levels integrate sectoral plans for nature conservation and development at the Länder, regional and municipal level (Landschaftsplanung), which promote greenspace protection and green corridor development. These plans are complemented by various types of nature conservation areas that protect specific spaces within the Regionalpark from development. Finally, the national nature conservation law provides financial compensation schemes for the destruction of natural areas. Here, the 
Regionalpark has benefited from such a financial compensation by the Frankfurt airport operator who had to transfer an amount of $€ 800$ thousand per year since 1997 to the Regionalpark RheinMain agency, with these funds being used to develop park projects (Dettmar, 2012; Rautenstrauch, 2015). Apart from its complex spatial planning and nature conservation arrangements, the Frankfurt region is also known for its delegation of public tasks to numerous special purpose organizations (Hoyler et al., 2006). This is also the case for the development of the regional greenbelt, which has been delegated from the Regional Authority to a special greenbelt agency - the Regionalpark Ballungsraum RheinMain $\mathrm{GmbH}$. Thus, this greenbelt agency is embedded within a fragmented regional institutional environment, influenced by various spatial planning and nature conservation authorities and other special purpose bodies operating at different spatial scales.

Similar to many other German regions, Frankfurt's regional greenbelt is termed a regional park. Introduced in the 1990s with little national policy guidance, regional parks take a flexible governance approach involving state, regional and municipal authorities (Gailing, 2007). Established in 1994, the Regionalpark RheinMain is currently 4463 $\mathrm{km}^{2}$ and was designed as a regional greenspace network, including the Frankfurt and Offenbach's municipal greenbelts, the Hessische Ried agricultural area and the Nature Park Hochtaunus. Similar to the Ontario case, the Regionalpark has multi-functional policy goals including greenspace protection, providing recreational areas, and promoting regional identity (Regionalverband, 2010). The Regionalpark is also meant to control the direction of regional development patterns and its primary land-uses are agriculture, forestry, recreation, and nature conservation areas. Following an initial period of management by the Regional Authority's predecessor, the Greater Frankfurt planning association, a regional greenbelt agency was founded in 2005 (Rautenstrauch, 2015). Thus, the park is managed by a special purpose body which is organized as a public-private partnership with its implementation delegated to six inter-municipal implementation bodies responsible for developing sub-projects. This greenbelt agency is supported by 15 shareholders including 123 municipalities, the Regional Authority, and the State of Hessen (Dettmar, 2012). In contrast to the GGH greenbelt, the Regionalpark is weakly protected. Apart from single areas protected by nature conservation law, its only formal protection is under the "regional green corridors" (Grünzüge) land-use category in the regional plan and the State Development Plan Hesse. Generally, there is broad public and political support for the Regionalpark's policy goals (Interview 3). However, regarding implementation, the greenbelt agency has no effective mechanisms for allocating land-uses and municipalities' membership within the Regionalpark is voluntary. Thus, the redistribution of land-use rights happens through the regionalised land-use plan and nature conservation laws. This process results in implementation problems such as creating land-use conflicts and opportunities for regional growth politics to undermine the Regionalpark's goals. 
To summarize, both regional greenbelts reflect a new generation of greenbelt planning with their multiple policy goals and diverse stakeholder involvement. However, their institutional design differs considerably: while the GGH greenbelt is supported by strong policy protection and a regional growth plan, the Regionalpark RheinMain benefits from protection through the spatial plans' promotion of a greenspace network and the designation of single nature conservation areas. The next sections will analyse and compare the governance challenges involved in developing regional greenbelts in the GGH and the Frankfurt metropolitan region's institutional environments.

\subsection{INSTITUTIONAL COMPLEXITIES AND GOVERNANCE CHALLENGES OF THE NEW GENERATION OF GREENBELTS}

In this section, we examine how greenbelt policy implementation in both cases is coordinated between stakeholders across multiple policy levels, policy fields and numerous jurisdictions. Our analytical framework of vertical, horizontal, and territorial coordination allows us to discuss the advantages and disadvantages of each greenbelt planning approach and to analyse the governance challenges involved in managing new generation greenbelts.

\subsubsection{Vertical coordination}

Greenbelt policies are often set by higher level of governments and should then be implemented by lower policy levels (Carter-Whitney, 2010). Often, the advantages of topdown approaches are highlighted as they give municipalities' clear direction for greenbelt policy implementation (Han and Go, 2019). However, these top-down models do not guarantee compliance, as municipalities often attempt to circumvent such regulations unless effective evaluation and sanctioning mechanisms are present.

In Ontario, greenbelt policies are implemented through a top-down institutional design, with plan implementation strongly influenced by provincial-municipal relations. Ontario's provincialmunicipal relationship is shaped by legislation that formally limits municipal autonomy, placing municipalities in a subordinate position to the Province (Côté and Fenn, 2014). Provincialmunicipal relations are characterized by some municipalities' resistance to provincial initiatives, a history of shifting provincial involvement in local matters, and contentious institutional reforms (ibid.). Tensions within this relationship are reflected in municipal non-compliance with provincial policies. Many municipalities have supported the Greenbelt and Growth Plans, while others have framed both plans as restrictions placed upon them. During the plans' initial implementation phase (2005-2015), municipalities took diverse approaches to achieve or circumvent these policy goals, resulting in inconsistent plan implementation (Burchfield, 2016). 
A weakness of the top-down greenbelt approach is its dependence on consistent higherlevel government mechanisms of support, evaluation, and sanctioning in cases of noncompliance. In Ontario, not all these support systems have been continuously applied to ensure greenbelt implementation. Compared to other international cases, the GGH greenbelt has one of the strongest legal frameworks and its policies are regularly reviewed (Carter-Whitney, 2010). While municipalities lacked clear provincial guidance during the Greenbelt and Growth Plans' initial implementation phase (Burchfield, 2016), the Province took a proactive approach during the 2015 policy review (Interview 4). While there are no specific non-compliance measures of the Greenbelt Plan, all land-use planning (non) conformity matters are governed by the provincial Planning Act. Under this Act, the Province has tools available to override municipal non-decisions, yet these sanctions are rarely invoked ${ }^{31}$. While the Liberals committed to a regional planning agenda, Frisken (2001) finds the Ontario government has a record of fluctuating involvement in regional affairs. This raises concerns about what happens to greenbelt planning when government priorities' shift, as these policies are susceptible to reform when political climates evolve. While the Liberals upscaled land-use planning to the new policy level of the GGH, they failed to establish a GGH regional government ${ }^{32}$. This lack of formal regional institutions has been a persistent problem for decades. Indeed, the Liberals assumed the role of regional government in absentia, as has happened throughout Ontario's history of regional governance (ibid.). Thus, while Ontario's top-down approach should in theory promote compliance of greenbelt implementation, these problems challenge its vertical institutional design's effectiveness.

In contrast, the Frankfurt region's greenbelt has a more decentralized approach. Policy formulation and implementation are loosely coordinated by the Regionalpark agency and municipalities having flexibility with implementation. The State of Hesse has a limited role in greenbelt planning, as the State Development Plan Hesse and the regional plan provide only general guidance on greenspace protection. By contrast, the Regional Authority has more involvement in Regionalpark planning through its planners' collaboration with the greenbelt agency's staff on relevant activities (Interview 3). However, the greenbelt agency's policies provide limited guidance to municipal land-use planning, making the greenbelt

31 The Planning Act requires that municipal plans be consistent with the Provincial Policy Statement and plans issued under it, including the Greenbelt Plan. It also requires municipalities to update their official plans to conform with provincial plans according to sections 3.5 and 26.1 of the Planning Act (1990). The Minister of Municipal Affairs and Housing can remove the approval powers of any delegated municipalities due to contraventions of those policies according to section 4.5 of the Planning Act (1990).

32 A regional government refers to a formal level of government situated between the GGH's single-tier, lower-tier and upper-tier municipalities and the provincial government. 
vulnerable to local self-interests. Thus, apart from some protected areas under nature conservation law, greenbelt management has been delegated to a weakly institutionalized special purpose body. The greenbelt agency has no spatial planning authority over its territory, limited staff capacity, faces financial uncertainty and must consult with multiple government and private sector organizations to complete its initiatives. Due to its limited planning jurisdiction, this agency's primary mandate shifted from its initial growth containment ambitions in 2008 to tourism promotion (Rautenstrauch, 2015). Given these constraints, the effectiveness of the greenbelt agency is limited.

When analysing the vertical institutional design of our cases, Ontario's top-down model provides stronger greenbelt policy protection compared to the Regionalpark's decentralized approach. However, Ontario's vertical institutional structure faces coordination difficulties at the local level, which will be explored in the next section.

\subsubsection{Horizontal coordination}

In both cases, greenbelt policy implementation happens at the municipal level and is influenced by challenges of coordinating multiple policy fields and their stakeholders. In Ontario, greenbelt policies stimulated better governance practices by facilitating stakeholder collaboration. Many municipalities have supported the Greenbelt Plan by developing projects with local partners (Hertel and Markovich, 2015). The Greenbelt Plan also supported some municipalities' efforts to move away from greenfield development, because as a municipal politician said "the greenbelt has reinforced and built on [our] perspective [of] what we were already doing, and has given it another level of protection and a regulatory regime." (Interview 1). The greenbelt policies have benefited from dedicated leaders that advocate for its protection. New organizations were established that increase stakeholders' participation opportunities such as the Friends of the Greenbelt Foundation. Through this foundation and civil society groups' efforts to promote the GGH greenbelt, it has broad public support, which is essential to a greenbelt's long-term success (Carter-Whitney, 2010). The success of the popularization of greenbelt sensitivities through these planning mechanisms can be measured over time by the increased community support in and around the greenbelt for the project overall. ${ }^{33}$

A persistent challenge, however, is that municipal growth politics may still undermine greenbelt policy objectives. Some municipalities "look at the greenbelt largely as an impediment to their economic viability, they feel hemmed-in, they feel they can't

33 The greenbelt's popular support showed in the broad rejection that now Premier Doug Ford experienced during the 2018 provincial election campaign concerning his proposed plans to soften the land-use controls put in place by the greenbelt legislation (Gray, May 1, 2018). 
attract new residential and non-residential development. They're just surrounded by the greenbelt, which is strangling them" (Interview 1). These municipalities want to continue their business-as-usual development practices and can be influenced by growth coalitions comprised of politicians and developers. Ontario's development industry has a major impact on municipal politics through contributions to local election campaigns. Indeed, the development industry is a key sponsor of political candidates which significantly influences local election results through donations, creating councils that favour developers' interests (Campaign Fairness Ontario, 2016). These pro-development councils in some municipalities continue to reproduce low-density development patterns, undermining the Greenbelt and Growth Plans' ambitions. While these municipalities must respect provincial planning legislation, they still may not fully embrace these policies. For example, during the first 10 years of the Growth Plan's implementation, most municipalities used the lowest possible intensification targets allowed under the plan (Burchfield, 2016). Thus, due to the diverse municipal responses to these plans and delays in updating local official plans to conform to provincial policies (ibid.), these plans' initial implementation had problems, resulting in inconsistent policy application.

In the Frankfurt region, the Regionalpark facilitates better governance practices. For example, a university-based researcher said that the Regionalpark has been successful at

"bringing together a lot of politicians of different colours, [giving] them the opportunity to discuss and to develop together something because all of them, it does not matter if they are Conservative, or Liberal or Social Democrats, are interested in keeping the value of [the] landscape. This is the connecting thing. All of them are interested in giving people [the] possibility for recreation and discovering landscape because this is very much asked [for] by the people." (Interview 3).

However, the Regionalpark's political acceptance has not translated into secure funding for the greenbelt agency. Indeed, the park is under the threat of the withdrawal of private funding in 2021 (Interview 5). The greenbelt agency's financial model is based on annual contributions from each of its municipal shareholders, the Regional Authority and the State of Hesse totalling 1.25 million€/year (Interview 5). The remaining 800,000€/year traditionally came from Fraport AG's contribution-the company managing Frankfurt's airport and the park's sole sponsor (Dettmar, 2012). To compensate for Fraport's withdrawal of funding, the park's governing parties have agreed to increase their financial contributions in the coming years (Interview 5). However, no official long-term decisions have been made at the time of writing and the impending loss of private funding creates financial uncertainty for the greenbelt. 
Moreover, the Regionalpark's weak institutional design combined with regional growth politics could undermine the greenbelt policies' effectiveness. Despite the strong spatial planning system and regionalised land-use planning promoting compact development, growth coalitions and inter-municipal competition influence regional growth resulting in continued suburbanisation (Monstadt and Meilinger, 2020). Likewise, the greenbelt agency has no capacity to shape regional growth patterns, rather focusing on easy-to-manage tourism goals that do not face resistance from growth coalitions. Politicians have mostly respected the greenbelt policies as a former director of the greenbelt agency stated that within the past 25 years, "there was no, or very few cases, where land that is a Regionalpark route or part of [a route] was lost to development. The Regionalpark policy of channelling the development on the whole [has been] moderately successful" (Interview 6). However, this greenspace's policies can still be undermined by regional growth politics.

To conclude, both greenbelt policies have increased governance capacity by strengthening partnerships. However, the increased multi-functionality of greenbelt policies results in intersections with diverse policy fields and their stakeholders, thus creating conflicts. In both cases, greenbelt management has been influenced by powerful interests such as developers and private funders that strongly shape and partially restrict greenbelt policy implementation.

\subsubsection{Territorial coordination}

Effective regional greenbelt implementation requires coordination across numerous territorial jurisdictions. Within urban regions, however, there are often mismatches between administrative and functional boundaries, causing institutional "misfits" and coordination challenges (Young, 2002). Greenbelt policies are designed to prevent urban development within the greenbelt's boundaries. As a result, urban growth often gets displaced elsewhere resulting in leapfrog development, which is characterized by development jumping over a greenbelt to farmland on the other side. Leapfrog development is problematic as it involves constructing roadways across a greenbelt that fragments greenspaces (Tomalty and Komorowski, 2011). In Ontario, the Greenbelt Plan has been effective in directing development to cities and away from farmland within the greenbelt (Ministry of Municipal Affairs and Housing, 2015). According to planners, farmers, and environmental activists (Interviews 7, 8 and 9), greenbelt policies have stimulated leapfrog development. However, our research indicates that this situation is more complex. The Greenbelt and Growth Plan work together to enable this low-density development to occur. While the Greenbelt Plan provides strong protection for farmland within its boundaries, growth pressures are offset elsewhere and farmland outside of these policies within the GGH can be vulnerable to development. Growth Plan implementation problems such as municipalities adopting low intensification targets and plan amendments allowing low-density development in 
Simcoe County, have encouraged suburbanisation beyond the greenbelt (Tomalty, 2015). However, while land speculation beyond the greenbelt is common, there is limited statistical information to confirm the scale of these practices within the $\mathrm{GGH}$, as governments do not keep these records (ibid.). Regardless, the explosive growth of communities outside of the greenbelt has created problems including agricultural de-investment (Interview 8) and coordination challenges with regional public service provision (Interview 9). Also, these development practices particularly impact farmers, as a representative from an agricultural organization said that these landowners

"who are in long-term career farming with the intent to pass the operation down [to their children], feel that particularly in those areas, there is a lot of pressure and probably same as in the past, worrying about land being bought by speculators for future growth because it's outside the greenbelt. It's sort of fair game. And what's the long-term meaning of that and what are the long-term implications if we just allow development to jump over and carry on?" (Interview 10).

These problems illustrate the importance for land-use regulations to prevent leapfrog development and the need to coordinate growth management policies across urban regions.

In the Frankfurt region, the greenbelt's implementation is affected by problems related to coordination challenges between different administrative jurisdictions. As an example of an institutional misfit, the Regionalpark is situated within a multi-layered territorial structure with the regional planning authority of South Hesse, the Regional Authority of Greater Frankfurt and municipalities operating at different territorial scales than the greenbelt agency, whose jurisdiction is defined by the park's boundaries (Figure 6.2). This complex institutional environment creates challenges for the greenbelt agency to effectively manage the park. For example, for this agency to promote its activities, staff must contact eight different tourism organizations overlapping the park's area, making it challenging to deliver a consistent greenbelt strategy (Interview 5). Due in part to the challenges associated with navigating this institutional complexity, park project development has been delegated to municipalities. Inter-municipal implementation bodies are responsible for delivering park projects, which facilitate governance processes by providing stakeholder engagement opportunities for park users (Krause, 2014). However, the delegation of greenbelt implementation to municipalities through small-scale projects prevents the creation of a comprehensive regional greenbelt. These localized initiatives cannot effectively manage regional growth pressures, nor were they designed to do so. 
In summary, both cases show that regional greenbelt policy implementation requires coordination across multiple municipalities, producing impacts beyond a greenbelt's boundaries. Indeed, effective regional greenbelt management requires municipal cooperation to implement policies. While cooperation is a strategy to address coordination problems, both cases are well-known for their difficulties with inter-municipal coordination at a regional scale (Nelles, 2012), which surely influences greenbelt implementation.

\subsection{CONCLUSION}

Through a comparative analysis of institutional arrangements of greenbelt management in two regions, this article explored the governance challenges involved in new generation greenbelts. By tracing the evolution of greenbelt development, we showed the considerable shifts in the greenbelt concept since its introduction more than a century ago. We analysed how these regions' institutional environments have impacted their greenbelts' implementation and pointed to challenges in vertical, horizontal, and territorial coordination. While greenbelt policies have facilitated the consolidation of greenbelts in both cases, varied results were achieved in meeting policy goals. In Ontario, for example, greenbelt policies have halted farmland conversions within the greenbelt and directed growth towards cities (Ministry of Municipal Affairs and Housing, 2015), yet stimulated leapfrog development according to stakeholder groups. In the Frankfurt region, the regional greenbelt agency has shifted away from focusing on core greenbelt policy goals such as growth control to promoting tourism, thus hardly providing an effective mechanism in addressing suburbanisation. Thus, while our comparative analysis shows that the GGH greenbelt has been more ambitious in achieving multiple greenbelt policy goals such as farmland protection and growth containment, both cases have produced mixed outcomes.

Another result of our research highlights that the complexity of both cases poses serious problems for policy implementation. As our study indicates, there are considerable challenges that come with the multiple policy goals and the regional scope of the recent generation of greenbelts. These greenbelts require policymakers to collaborate across policy domains and municipalities, while also restricting municipalities and investors' development interests. Local planners face challenges in implementing these recent greenbelt policies often resulting in inconsistent municipal policy implementation (Interview 7). While recent greenbelt policies have surely raised greater awareness of policy interconnectivity and of the need for more integrated greenbelt projects, they also require a high governance capacity to coordinate efforts to confine urban development. Thus, this requires a re-prioritization of greenbelt policy goals, with urban growth containment and nature conservation as key concerns. In addition, ongoing monitoring 
is needed to evaluate the effectiveness of greenbelt policies in achieving their goals and these policies need to be updated regularly to reflect changing regional conditions. Finally, greenbelt policies need to be supported by other policies such as a regional growth plan. Such integrated frameworks are necessary to effectively address regional growth management concerns.

In addition to these policy developments, the effective governance of new generation greenbelts requires institutional reforms. As regional planning evolves, there is an increased emphasis on flexible institutional approaches including soft governance spaces (Allmendinger and Haughton, 2009), the use of special purpose bodies for public service provision (Lucas, 2013), and regional partnerships (Nelles, 2012). However, these special purpose agencies and voluntary arrangements often have limited authority, can only encourage stakeholder collaboration, and cannot overcome institutional fragmentation in urban regions. Our research indicates that these collaborative approaches as seen in the Frankfurt case do not ensure effective regional greenbelt policy implementation. Instead, as our Ontario case reflects, greenbelt planning should be integrated into provincial governments or state planning authorities, as these are the most suitable institutions to manage new generation greenbelts. Senior levels of government have the required statutory powers to establish greenbelt legislation, confine regional growth and have jurisdiction over the appropriate territorial scope for regional greenbelt management (Pond, 2009). Higher levels of government have also been viewed as being more effective at coordinating public policy implementation (Nelles, 2012), as these authorities have more resources available than special purpose bodies to support policy implementation and can enforce compliance mechanisms, if municipalities try to circumvent these regulations. Thus, despite the popularity of flexible greenspace protection approaches (Lennon, 2015), regional greenbelts require institutional reforms and new policy developments to effectively manage the institutional complexity and governance challenges facing new generation greenbelts.

In an era of global suburbanisation and climate change, policymakers must make decisions about how to best govern urban regions in today's new urban world. Greenbelts are increasingly important for planning regional futures, as for example the GGH greenbelt builds resiliency against environmental threats by providing ecosystem services (Green Analytics, 2016). The Ontario and Frankfurt cases add a new chapter to greenbelt debates, illustrating that new generation greenbelts require different institutional structures than their traditional predecessors did to enable their effective governance. Thus, the institutional arrangements supporting regional greenbelts need to be updated to reflect the current complexity of urban regions, so that these greenspaces can be better governed to continue providing the valuable environmental assets needed by urban regions. 


\subsection{REFERENCES}

Addie, J. P., \& Keil, R. (2015). Real existing regionalism: The region between talk, territory and technology. International Journal of Urban and Regional Research, 39(2), 407-417.

Allen, R. and Campsie, P. (2013). Implementing the growth plan for the Greater Golden Horseshoe. Has the strategic regional vision been compromised? The Neptis Foundation. Retrieved from http://www.neptis.org/publications/implementing-growth-plan-greater-golden-horseshoe

Allmendinger, P., \& Haughton, G. (2009). Soft spaces, fuzzy boundaries, and metagovernance: The new spatial planning in the Thames gateway. Environment and Planning A, 41(3), 617-633.

Amati, M. (Ed.). (2008). Urban green belts in the twenty-first century. Hampshire, England: Ashgate.

Amati, M., \& Taylor, L. (2010). From green belts to green infrastructure. Planning Practice \& Research, 25(2), 143-155.

Burchfield, M. (2016). Province must embrace its role as regional planner for growth plan to succeed. The Neptis Foundation. Retrieved from http://www.neptis.org/latest/news/province-mustembrace-its-role-regional-planner-growth-plan-succeed

Cadieux, K. V., Taylor, L. E., \& Bunce, M. F. (2013). Landscape ideology in the Greater Golden Horseshoe greenbelt plan: Negotiating material landscapes and abstract ideals in the city's countryside. Journal of Rural Studies, 32, 307-319.

Campaign Fairness Ontario. (2016). If it's broke, fix it. A report on the money in municipal campaign finances of 2014.

Carter-Whitney, M. (2010). Ontario's greenbelt in an international context. Friends of the Greenbelt Foundation. Retrieved from https://www.greenbelt.ca/ontario_s_greenbelt_in_an_ international_context2010

Côté, A. and Fenn, M. (2014). Provincial-municipal relations in Ontario: Approaching an inflection point. Institute on Municipal Finance and Governance. Retrieved from https://munkschool. utoronto.ca/imfg/uploads/275/1560_imfg_no_17_online_full_colour.pdf

Dettmar, J. (2012). Weiterentwicklung des regionalparks RheinMain. In Monstadt, J., Schönig, B., Zimmermann, K., \& Robischon, T. (Eds.). Die diskutierte region: Probleme und planungsansätze der metropolregion Rhein-Main. (pp. 231-254). Frankfurt, Germany: Campus Verlag.

Filion, P., \& McSpurren, K. (2007). Smart growth and development reality: The difficult co-ordination of land use and transport objectives. Urban Studies, 44(3), 501-523.

Freestone, R. (2002). Greenbelts in city and regional planning. In Parsons, K., and Schuyler, D. (Eds.). From garden city to green city: The legacy of Ebenezer Howard. (pp. 67-98). Baltimore, MD: John Hopkins.

Frisken, F. (2001). The Toronto story: Sober reflections on fifty years of experiments with regional governance. Journal of Urban Affairs, 23(5), 513-541.

Gailing, L. (2007). Regional parks: Development strategies and intermunicipal cooperation for the urban landscape. German Journal of Urban Studies, 46(1).

Glass, M. (2018). Navigating the regionalism-public choice divide in regional studies. Regional Studies, 52(8), 1150-1161.

Gray, J. (May 1, 2018). Doug Ford recants vow to allow greenbelt development. The Globe and Mail. Retrieved from https://www.theglobeandmail.com/canada/toronto/article-doug-ford-recantsvow-to-allow-greenbelt-development/ 
Green Analytics. (2016). Ontario's good fortune: Appreciating the greenbelt's natural capital. Friends of the Greenbelt Foundation. Retrieved from https://d3n8a8pro7vhmx.cloudfront. net/greenbelt/pages/2825/attachments/original/1485878510/OP_20_Web_version_2017. pdf?1485878510

Hall, P. (2007). Rethinking the mark three green belt. Town and Country Planning. 76(8): 229-231.

Hall, P. A., \& Taylor, R. C. (1996). Political science and the three new institutionalisms. Political Studies, 44(5), 936-957.

Hamel, P., \& Keil, R. (Eds.). (2015). Suburban governance: A global view. Toronto, Canada: University of Toronto Press.

Han, A. T., \& Go, M. H. (2019). Explaining the national variation of land use: A cross-national analysis of greenbelt policy in five countries. Land Use Policy, 81, 644-656.

Hertel, S. and Markovich, J. (2015). Local leadership matters: Ontario municipalities taking action to strengthen the greenbelt. Friends of the Greenbelt Foundation. Retrieved from https://www. greenbelt.ca/local_leadership_matters_greenbelt2015

Hoyler, M., Freytag, T., \& Mager, C. (2006). Advantageous fragmentation? Reimagining metropolitan governance and spatial planning in Rhine-Main. Built Environment, 32(2), 124-136.

Jessop, B. (2000). The crisis of the national spatio-temporal fix and the tendential ecological dominance of globalizing capitalism. International Journal of Urban and Regional Research, 24(2), 323-360.

Keil, R., Hamel, P., Boudreau, J. A., \& Kipfer, S. (Eds.). (2017). Governing cities through regions: Canadian and European perspectives. Waterloo, ON: Wilfrid Laurier University Press.

Krause, R. (2014). Placemaking in the RhineMain regionalpark. (Master's thesis, Karlskrona, Sweden, Blekinge Institute of Technology). Retrieved from http://www.diva-portal.se/smash/get/ diva2:832027/FULLTEXT01.pdf

Lennon, M. (2015). Green infrastructure and planning policy: A critical assessment. Local Environment, 20(8), 957-980.

Lowndes, V. (2010). The institutional approach. In March, D., \& Stoker, G. (Eds.). Theory and methods in political science. ( $3^{\text {rd }}$ ed). (pp. 67-98). Houndmills, England: Palgrave MacMillan.

Lucas, J. (2013). Hidden in plain view: Local agencies, boards, and commissions in Canada. IMFG Perspectives 4. Retrieved from https://munkschool.utoronto.ca/imfg/uploads/253/ imfg_1453hiddeninplainview_final_web.pdf

Macdonald, S., \& Keil, R. (2012). The Ontario greenbelt: Shifting the scales of the sustainability fix? The Professional Geographer, 64(1), 125-145.

Mace, A. (2018). The metropolitan green belt, changing an institution. Progress in Planning, 121, $1-28$.

March, J. G., \& Olsen, J. P. (2011). Elaborating the "new institutionalism". In Goodin, R. (Ed.). The Oxford handbook of political science. (pp. 159-175). Oxford, England: Oxford University Press.

Monstadt, J. and Meilinger, V. (2020). Governing suburbia through regionalized land-use planning? Experiences from the Greater Frankfurt region. Land Use Policy. 91.

Ministry of Municipal Affairs. (2017). Greenbelt plan, 2017. Retrieved from http://www.mah.gov. on.ca/Page13783.aspx

Ministry of Municipal Affairs and Housing. (2015). Performance indicators for the greenbelt plan. Part 1, 2015. Retrieved from http://www.mah.gov.on.ca/AssetFactory.aspx?did=10850

Ministry of Municipal Affairs and Housing. (2019). Growth plan for the Greater Golden Horseshoe, 2019. Retrieved from https://www.placestogrow.ca/index.php?option=com content\&task=view\&id=9\&|temid=14 
Nelles, J. (2012). Comparative metropolitan policy: Governing beyond local boundaries in the imagined metropolis. London, England: Routledge.

Paasi, A., \& Metzger, J. (2017). Foregrounding the region. Regional Studies, 51(1), 19-30.

Peters, B. G. (2019). Institutional theory in political science: The new institutionalism. (4 ${ }^{\text {th }}$ ed.). Cheltenham, England: Edward Elgar Publishing.

Phelps, N., \& Wu, F. (Eds.). (2011). International perspectives on suburbanization: A post-suburban world? London, England: Palgrave Macmillan.

Planning act 1990, (ON). s.3.5, 4.5, 26.1 (CA). Retrieved from https://www.ontario.ca/laws/ statute/90p13

Pond, D. (2009). Institutions, political economy and land-use policy: Greenbelt politics in Ontario. Environmental Politics, 18(2), 238-256.

Rautenstrauch, L. (2015). Regionalpark RheinMain - Die geschichte einer verführung. Regionalpark RheinMain Ballungsraum GmbH. Frankfurt, Germany: Societaets Verlag.

Regionalverband $=$ Regional Authority FrankfurtRhineMain (2018). Regionales monitoring 2018. Daten und fakten - metropolregion FrankfurtRheinMain. Frankfurt, Germany.

Regionalverband (2010). Regionalplan Südhessen / Regionaler flächennutzungsplan, allgemeiner textteil of October 17, 2010. Darmstadt, Germany.

Robinson, J. (2011). Cities in a world of cities: The comparative gesture. International Journal of Urban and Regional Research, 35(1), 1-23.

Röhring, A., \& Gailing, L. (2005). Institutional problems and management aspects of shared cultural landscapes. Conflicts and possible solutions concerning a common good from a social science perspective. Leibniz-Institute for Regional Development and Structural Planning (IRS), Erkner, Germany.

Schmidt, S., Siedentop, S., \& Fina, S. (2018). How effective are regions in determining urban spatial patterns? Evidence from Germany. Journal of Urban Affairs, 40(5), 639-656.

Sieverts, T. (2003). Cities without cities: An interpretation of the zwischenstadt. London, England: Routledge.

Stoker, G. (1998). Governance as theory: Five propositions. International Social Science Journal, 50(155), 17-28.

Sturzaker, J., \& Mell, I. (2017). Green belts: Past; present; future? London, England: Routledge.

Taylor, L. (2019). The future of green belts. In Scott, M., Galant, N. and Gkartzios, M. (Eds). Routledge companion to rural planning. ( $1^{\text {st }}$ ed.). (pp. 458-468). New York, NY: Routledge.

Taylor, Z. (2019). Shaping the metropolis: Institutions and urbanization in the United States and Canada. Montreal, QC: McGill-Queen's Press.

Tomalty, R. (2015). Farmland at risk: How better land use planning could help ensure a healthy future for agriculture in the Greater Golden Horseshoe. Ontario Federation of Agriculture and Environmental Defense. Retrieved from https://environmentaldefence.ca/2015/11/24/ontariofarmland-at-risk-better-land-use-planning-can-help-save-the-family-farm/

Tomalty, R. and Komorowski, B. (2011). Inside and out: Sustaining Ontario's greenbelt. Friends of the Greenbelt Foundation. Retrieved from http://www.greenbelt.ca/inside_and_out_sustaining_ ontario_s_greenbelt2011

Willi, Y., Pütz, M., \& Müller, M. (2018). Towards a versatile and multidimensional framework to analyse regional governance. Environment and Planning C: Politics and Space, 36(5), 775-795.

Young, O. (2002). The institutional dimensions of environmental change: Fit, interplay, and scale. London, England: MIT Press. 


\subsection{APPENDIX: CITED INTERVIEWS}

\begin{tabular}{|c|c|c|c|}
\hline Interview No. & Position Title & Organization & Date \\
\hline 1 & Politician & GGH Region Municipality & August 20, 2014 \\
\hline 2 & Manager & $\begin{array}{l}\text { GGH Region Environmental } \\
\text { Organization }\end{array}$ & October 17, 2017 \\
\hline 3 & Researcher & $\begin{array}{l}\text { Technische Universität } \\
\text { Darmstadt, Darmstadt }\end{array}$ & $\begin{array}{l}\text { March 9, } 2018 \text { and } \\
\text { July 18, } 2019\end{array}$ \\
\hline 4 & Senior Planner & $\begin{array}{l}\text { Ministry of Municipal Affairs } \\
\text { and Housing, Ontario } \\
\text { Government }\end{array}$ & August 29, 2018 \\
\hline 5 & Director & $\begin{array}{l}\text { Regionalpark Ballungsraum } \\
\text { RheinMain GmbH, Flörsheim } \\
\text { am Main }\end{array}$ & $\begin{array}{l}\text { May 18, 2018, } \\
\text { August 23, } 2018 \text { and } \\
\text { July 15, } 2019\end{array}$ \\
\hline 6 & Former Director & $\begin{array}{l}\text { Regionalpark Ballungsraum } \\
\text { RheinMain GmbH, Flörsheim } \\
\text { am Main }\end{array}$ & September 9, 2018 \\
\hline 7 & Community Planner & GGH Region Municipality & November 6, 2018 \\
\hline 8 & Activist and Farmer & $\begin{array}{l}\text { GGH Region Environmental } \\
\text { Organization }\end{array}$ & August 19, 2014 \\
\hline 9 & Activist and Consultant & $\begin{array}{l}\text { GGH Region Environmental } \\
\text { Organization }\end{array}$ & $\begin{array}{l}\text { October 22, } 2014 \text { and } \\
\text { April 2, } 2019\end{array}$ \\
\hline 10 & Senior Staff Member & $\begin{array}{l}\text { GGH Regional Farming } \\
\text { Organization }\end{array}$ & August 26, 2014 \\
\hline
\end{tabular}





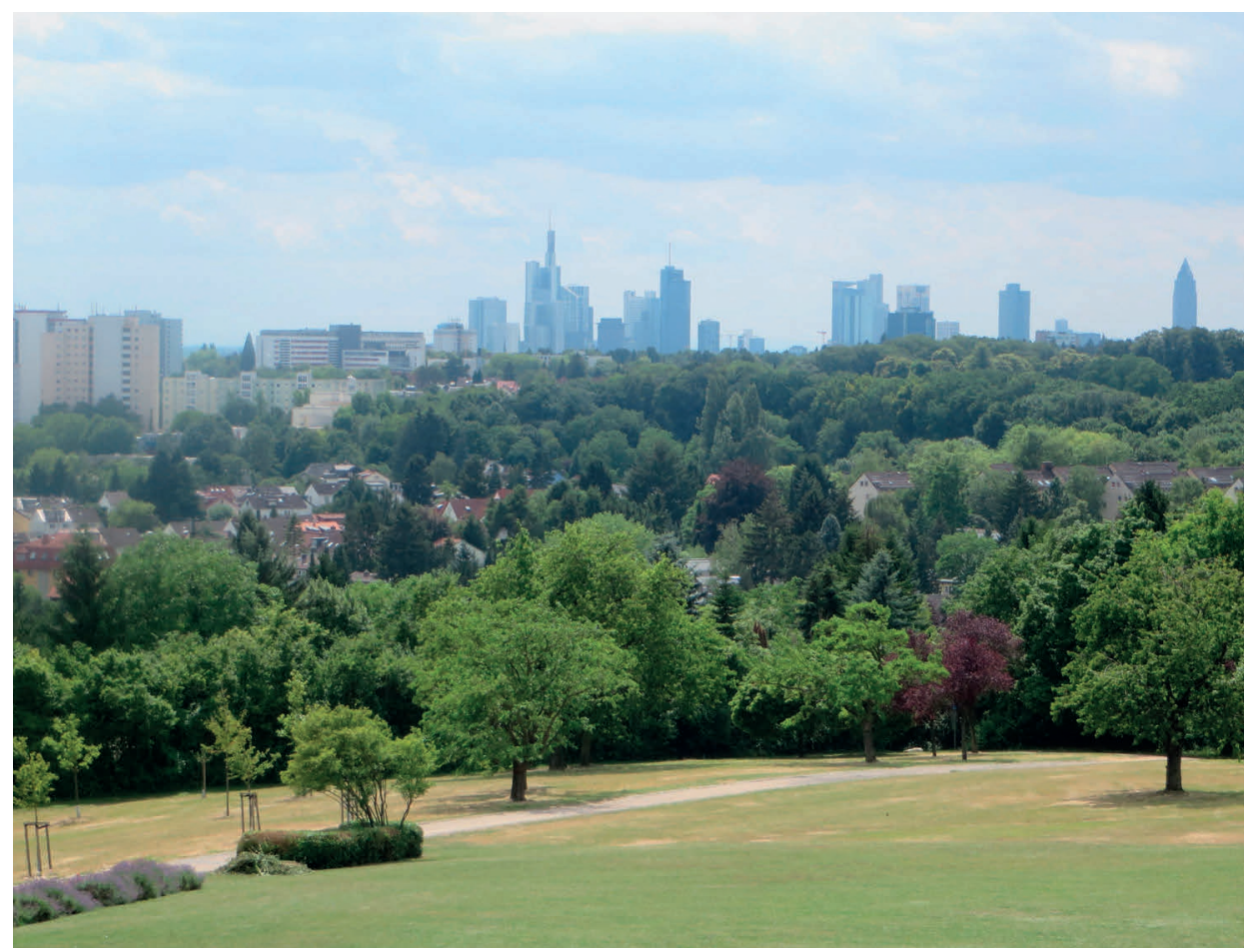

View from the Lohrberg, Frankfurt greenbelt (2015).

Source: author 
Conclusion

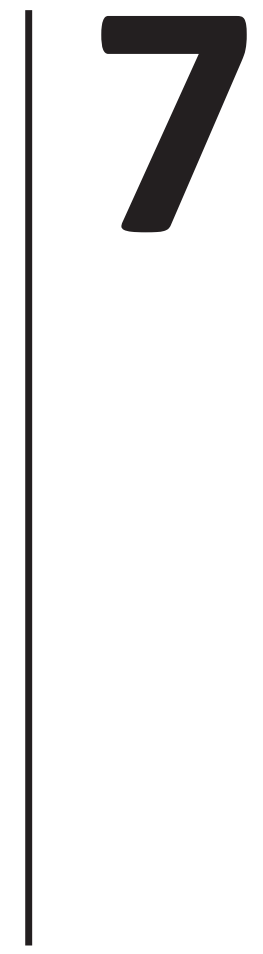





\subsection{INTRODUCTION}

Greenbelt planning has evolved significantly since originating in British planning more than one hundred years ago. In my research, I demonstrate that a new generation of greenbelts emerged in the past 30 years. These contemporary greenbelt policies often pursue multi-functional policy goals that belie the simplicity of the city-countryside dichotomies associated with early $20^{\text {th }}$ century British greenbelts. These recent greenbelts are now situated in landscapes of regional suburban growth and embedded in complex regional institutional and governance arrangements. With regional governance structures shifting in recent decades as a result of state de-regulation and re-regulation (Zimmerman et al., 2020), and the increasing involvement of private and civil society stakeholders in environmental governance (Kortelainen, 2010), this research explores how these processes have influenced regional greenbelt management. Greenbelts are increasingly under threat from urban and suburban growth, infrastructure development, and climate change, all of which can undermine the environmental integrity of these greenspaces (Carter-Whitney, 2010). These changing circumstances create significant challenges for policymakers seeking solutions to effectively manage these regional greenspaces and raise questions if greenbelt policies can achieve their ambitious goals.

However, the institutional complexities and governance challenges of managing regional greenbelts are not well reflected in academic debates. Some literature examines the governance of regional greenbelts (Burton, 2016; Kortelainen, 2010; Wekerle et al., 2007), while other scholars take an institutional perspective on greenbelt planning (Han and Go, 2019; Mace, 2018; Pond, 2009). However, the institutional approaches in these debates rarely reflect upon the governance of these greenspaces, with some exceptions (Röhring and Gailing, 2005). In addition, greenbelts are hardly discussed in urban political ecology debates, with the following exceptions (Allen, 2014; Keil, 2018). UPE scholarship has also rarely discussed the types of boundary questions in relation to suburbanisation and greenbelts that this research explores. Finally, while there is literature comparing greenbelt planning practices in multiple countries (Aguado et al., 2017; Amati, 2008; Carter-Whitney, 2010), none of these studies take an institutional approach to examining these greenspaces, with one exception (Han and Go, 2019).

Taking these literature gaps as a starting point, my research comparatively analyses two cases to explore the challenges involved in regional greenbelt governance. The overall objective of this research is to gain an understanding of how institutions influence the governance of regional greenbelts. The previous chapters provided detailed analysis of how institutional complexities and governance challenges have impacted regional greenbelt policy implementation in the GGH and Frankfurt Rhine-Main regions. This discussion provides the basis to answer the main research question: 
How do institutional arrangements shape the governance of regional greenbelts and how could these greenspaces be more effectively governed?

This chapter is organised as follows. First, I summarise the main results of this thesis, which answers three of the research questions. Then, I answer the fourth research question by providing suggestions about how the governance and planning of regional greenbelts could be improved. Following that, I outline my contributions to the academic debates on regional governance from an institutional perspective. Finally, I provide some directions for future research.

\subsection{MAIN RESEARCH FINDINGS}

The introduction presented one main research question and four additional questions to explore how institutions influence regional greenbelt governance, and to make recommendations about how these greenspaces could be better managed in the future. In this section, I summarise the main results related to the first three questions, which I examined in chapters 2 to 6 .

1. How can an understanding of regional greenbelts be advanced through a political ecology approach?

My research reveals that an urban political ecology (UPE) approach provides a valuable perspective to better understand what greenbelts are and how they are being produced and reproduced. First, UPE redefines what is seen as nature, viewing all features of urbanisation as being socio-natural, which become hybrid objects that are natural and social (Swyngedouw, 2004; Wachsmuth, 2012). Greenbelts can be seen as hybrid spaces that are socially produced or reproduced, formed by numerous natural, social, and political processes, and facilitated through societal relationships with nature. For example, greenbelts are established by land-use planning policies requiring a political process to achieve government approval to protect these greenspaces. Greenbelts are also comprised of natural spaces that form part of regional flows of water, waste, and energy, supporting natural environments. Once established, greenbelts can become part of an urban region's identity. Residents can develop a social connection to these greenbelts through participating in greenbelt-related activities, resulting in broader public support of them. Thus, I argue that greenbelts can be viewed as being formed through the combination of political, natural, and social processes, with the changing dynamics of these processes over time shaping their reproduction. 
In addition, under UPE, the reproduction of nature is nested in territorial networked relations extending from the local to the international level (Heynen et al., 2006; Swyngedouw and Heynen, 2003). Greenbelts are situated in numerous social, political, economic, and environmental relations linked together by multi-scalar geographical arrangements that operate from the municipal to the international scales. For example, greenbelt policies intersect with other sectoral plans from multiple policy levels. In the Frankfurt case, the Regionalpark forms a bigger regional greenspace network, including the Frankfurt greenbelt, the Offenbach greenbelt, a biosphere reserve, a national park, and nature parks, each protected by various municipal, regional, or state policies. At the same time, national and European nature regulations (e.g. the Federal Nature Conservation Act, the Habitats Directive), national spatial planning legislations, but also housing, economic growth and transportation polices shape the management and governance of greenbelts. Thus, through these multi-scalar connections, the production and reproduction of urban and regional nature are linked to broader processes extending far beyond the territorial scope of greenspaces. Therefore, viewing regional greenbelts as hybrid spaces embedded in multi-scalar geographical relations helps to understand how larger political and socionatural connections influence their governance.

Second, also under UPE, the production of nature involves uneven and often unjust power relations that benefit some actors while disadvantaging others (Heynen et al., 2006). Applying a UPE lens to greenbelt planning allows for an examination of which stakeholders gain or lose by establishing a greenbelt. On the one hand, my research reveals that powerful stakeholders have the resources to disproportionately impact land management activities. In the Ontario case, for example, the development industry has significant financial resources to successfully lobby for exceptions to land-use planning regulations. This considerable influence is seen through some developers' contributions to municipal election campaigns, or the lobbying of provincial officials prior to the greenbelt's establishment in 2005 and before the 2015 policy review. In contrast, other stakeholders can be marginalised in greenbelt governance processes. In the Ontario case, for example, civil society groups often lack the resources to effectively fight developers in appeals at the land-use planning tribunal. By applying a UPE perspective to greenbelt planning, my research reveals the uneven power relationships and sometimes unjust conditions under which greenbelts are produced and reproduced.

Finally, UPE seeks to break down dualistic thinking about nature and society, criticising the divisions between urban and natural environments (Heynen, 2014; Wachsmuth, 2012). As planning policies intended to contain urban growth, greenbelts are often designed to create a firm division between urban and rural areas. However, as I discuss in chapter 2 , societal relationships between nature and cities have evolved over time, and nature 
is now seen as part of the urban realm. Greenbelts established more than one hundred years ago in England were based on the idea of a pristine countryside, which has come under criticism today. By contrast, my research shows that new generation greenbelts are complex landscapes, representing a working countryside that includes a diversity of agricultural and recreational activities to support urban and rural economies. In addition, key urban functions have shifted to the suburbs in recent decades, as major employment and transportation nodes are increasingly located in suburban areas. Thus, the traditional divisions associated with early $20^{\text {th }}$ century greenbelts are reconsidered through a UPE lens, which better reflects the current conditions found in the urban fringe. Therefore, in chapter 2, I argue that rather than being a hard line, greenbelts can now be seen as a territorial threshold that forms a more fluid boundary between urban, suburban, and rural areas.

This blurring of the city-countryside boundaries highlights an increasingly complex production of urban and suburban environments, with examples of these changing relationships in both cases. While greenbelt policies are designed to contain urban growth, they are not always effective, as evidenced by the Ontario case. As discussed in chapters 3, 5 and 6, my research demonstrates that the Greenbelt Plan has facilitated low-density development to 'leap' over the greenbelt's boundaries, occurring on farmland on the other side. Yet the growth of these communities requires the construction and expansion of roadways across the greenbelt to service these new developments, thus allowing for commuter flows and infrastructure to perforate these greenspaces' boundaries.

In addition, my research shows that greenbelts play a key role in the metabolic relationships that sustain urban regions. Greenbelts promote the conservation of natural habitats and of farmland and form part of broader networks of water, waste and energy flows linking rural areas and cities. In fact, these connections often extend far beyond a greenbelt's boundaries. For example, in the Ontario case, the GGH greenbelt is a major drinking water source for the region's residents, protecting the headwaters of rivers that flow through the city of Toronto into Lake Ontario.

Finally, as I discuss in chapter 2, my research reveals that the relationship between agriculture and the city is changing. The agricultural mode of production seen in greenbelts has shifted in recent years. It is no longer driven only by agricultural pursuits, but rather has shifted towards urban residents' interests. Thus, what can be termed 'para-agriculture' has emerged in greenbelts, reflecting the growing popularity of agri-tourism activities in both cases. Through para-agriculture, however, greenbelts can become spaces of privilege that are accessible only to a specific segment of the public who can afford to participate in these activities, which raises equity concerns about how greenbelts are used, and for whom. 
To conclude, by viewing greenbelts through a UPE lens, these greenspaces can be seen as hybrid spaces that dissolve firm boundaries between the city and the countryside. Instead, my research shows that greenbelts have become a prime space for the negotiation of societal relationships with nature, which are connecting urban and non-urban activities in new ways.

\section{How does regionalisation shape the governance and planning of greenbelts?}

Greenbelts today are situated in polycentric urban regions that are often rapidly growing and contain a diversity of land-uses, densities, urban and suburban forms. In recent decades, the traditional connections between central cities and their surrounding suburbs have changed, with an increased regionalisation of labour and service industries, suburban growth, commuter patterns and infrastructure networks. Therefore, with these evolving regionalisation processes comes a greater need for growth management initiatives, such as regional greenbelts, to strongly protect farmland and natural areas. However, while regional planning and institutions are needed to effectively manage environmental policies, these policies are often still localised. Thus, the regionalisation of environmental policies is often lacking, which is reflected in both case studies.

As discussed in chapter 3, the Greenbelt Plan forms part of an ambitious and integrated regional planning framework for Southern Ontario. The Greenbelt Plan builds upon a history of regional nature conservation areas including the Niagara Escarpment and the Oak Ridges Moraine, which were designated by the provincial government. Through greenbelt legislation, the Liberal provincial government upscaled traditional urban-regional regulation to a new policy level: the Greater Golden Horseshoe. In chapter 3, I argue that the Greenbelt Plan can be viewed as a regional sustainability fix, as through these policies, the Liberal government was attempting to regulate regional growth pressures and their environmental impacts at a new regional scale. ${ }^{34}$ However, this upscaling of urban-regional regulation was implemented without the creation of a regional government for the GGH region. Instead the provincial government took on the role as the regional government in absentia.

In the Frankfurt case, I show in chapter 4 that the Regionalpark was designed to upscale municipal initiatives such as the Frankfurt and Offenbach greenbelts to a regional scale, and to integrate them into a regional greenspace network. However, my research indicates that

34 In my research, I applied While et al. (2004)'s concept of an urban sustainability fix to the regional scale. While et al. (2004) define this concept as involving the incorporation of environmental goals into the greening of urban governance, highlighting the challenges governments face in balancing economic, social, and ecological demands. 
the institutional arrangements supporting the Regionalpark are ineffective. The regional greenbelt agency is weakly institutionalised, and while its main mandate is tourism promotion rather than environmental protection, the agency's concrete project initiatives are all restricted to the local scale. Moreover, there is no regional greenbelt plan, and policy protection of the Regionalpark through the regionalised land-use plan is rather limited given the pressure of local growth coalitions (Monstadt and Meilinger, 2020). Therefore, my research shows that greenbelt planning in both cases could be better institutionalised at the regional level and this lack of institutional support contributes to the coordination problems between organisations and stakeholders, which I discuss in response to the third question below.

Suburbanisation at the regional scale and its associated growth politics strongly shape the governance and planning of new generation greenbelts. For example, regional housing market problems can create pressure for politicians to relax growth controls, allowing for new development within greenbelts. In the Frankfurt case, regional population growth has put intense pressure on the Greater Frankfurt region's housing market, with the supply of new housing unable to keep pace with demand. As a result, the City of Frankfurt has proposed a new development for 30,000 residents at the edge of its greenbelt, generating fierce opposition from local residents and those in neighbouring communities. This development would be allowed because it is not located within the greenbelt itself, and recent reforms to the German building code have reduced land-use restrictions on unbuilt land (Monstadt and Meilinger, 2020). However, this development could put intense pressure on the greenbelt, and may also disrupt Regionalpark routes. At the time of writing, this controversial development is still in its initial stages and will take years to complete. Likewise, in the Ontario case, my research shows that some developers view the Greenbelt Plan as contributing to housing affordability problems because this legislation restricts land supplies. Thus, these developers lobbied provincial government officials ahead of the 2015 policy review to loosen restrictions in the revised policies and allow for more growth; yet, they were ultimately unsuccessful in their efforts. However, these examples highlight that growing regional housing demands can threaten greenbelt protection.

An additional aspect of the effects of growth politics on greenbelts is the influence of local growth coalitions on growth confinement practices. As discussed in chapters 5 and 6 , some Ontario developers make financial donations to municipal election campaigns, leading to the creation of pro-growth councils. While municipalities must comply with provincial policies, they may still be resistant to them and search for exceptions to continue their lowdensity development practices. Thus, my research reveals that this pro-growth mentality of some suburban GGH municipal councils undermines the spirit of the Greenbelt and Growth Plans and creates conflicts with civil society groups. Through these examples, 
my research demonstrates that development pressures and regional growth policies can undermine effective greenbelt policy implementation and create tension among stakeholders, ultimately affecting greenbelt governance.

To conclude, greenbelts are now situated in complex urban regions shaped by the regionalisation of low-density development in suburban areas, economic networks, and commuter flows, making municipal greenbelts no longer sufficient. Instead, greenbelts need to have a regional scope and require adequate institutional support in order to achieve the ambitious policy goals of new generation greenbelts.

3. How is greenbelt implementation coordinated across multiple territorial jurisdictions, policy domains and policy levels?

The aim of this research question is to analyse how institutions influence greenbelt policy implementation through the dimensions of vertical, horizontal, and territorial coordination, which I discuss in chapters 4 to 6 . Greenbelts are now situated in complicated institutional and governance arrangements with multiple stakeholders involved in their management. My research indicates that these institutional arrangements have a significant influence on greenbelt policy implementation. My cases reveal that the complexity of managing all the interactions between different stakeholders and institutions involved in new generation greenbelt management causes major problems, impacting policy outcomes. Therefore, my research on this question makes several contributions to understanding the role institutions play in shaping greenbelt governance related to: (1) vertical coordination, (2) horizontal coordination, and (3) territorial coordination.

First, based on both cases, my research demonstrates that the vertical coordination of greenbelt policies among different policy levels has a considerable influence on the management of these greenspaces. On the one hand, greenbelt policy implementation is often seen as a top-down approach whereby higher levels of government provide policy direction, while lower level authorities are responsible for policy implementation (Carter-Whitney, 2010). However, my research reveals that vertical coordination in both cases is in fact a more complicated arrangement including both top-down and bottom-up interactions, which are considerably shaped by uneven power relations between policy levels. The Ontario case reflects a nested arrangement that includes a formal top-down approach to greenbelt planning, with bottom-up mechanisms that occur at the same time. As discussed in chapters 5 and 6 , Ontario has a provincially led land-use planning system. In addition, provincial-municipal relations are strongly shaped by legislation limiting municipal authority, making municipalities 'creatures of the Province'. Thus, the Greenbelt Plan reinforces this hierarchical provincial-municipal relationship, whereby the 
provincial government remains firmly in control to assert authority over municipalities, if needed. However, bottom-up approaches also have a role in this process. There are formal mechanisms for municipalities to comment on provincial policies, for example, through the 2015 coordinated policy review. Informal processes are also important as the communication between provincial and municipal staff - which is almost exclusively initiated by municipalities - is needed to resolve problems, leading to more effective policy implementation.

In contrast to the top-down approach in Ontario, the Frankfurt case has a much more decentralised arrangement of greenbelt planning, which includes a mixture of top-down and bottom-up approaches that are interconnected through multiple policy levels. As I explain in chapter 4, the German spatial planning system is based on distinctive policy levels that integrate relevant sectoral policies and plans. Under its 'principle of countervailing influence,' local, regional and Länder spatial plans each influence, and are in turn influenced by the other levels of planning. Unlike in Canada, German constitutional law, however, provides municipalities a high degree of autonomy in spatial planning matters. In Germany, the major operational tasks in spatial planning rests with the Länder and the municipalities. The state development plan for Hesse and the regional plan for South Hesse set broader spatial planning regulations, designate areas where municipalities cannot build and establish major environmental protection zones. These regional planning objectives from the Länder and South Hesse levels are then further detailed in the Regional Authority's regionalised land-use plan. This intermunicipal coordination mechanism is an exceptional case in Germany where municipalities usually have the authority to designate land uses more autonomously. Each of these spatial plans includes policies to secure the Regionalpark, and the park is further protected by nature conservation and landscape planning policies at several policy levels.

My research shows several weaknesses in the institutional design of greenbelt planning in this case. The state government, including its spatial planning authorities at the Länder and South Hesse levels, does not take an active role in greenbelt management. However, the Regional Authority does have greater involvement with Regionalpark planning. At the same time, the Regional Authority only has responsibility over a portion of the Regionalpark's territory, which stretches beyond the Greater Frankfurt area, crossing the territorial scopes of the regional planning authorities of South Hesse and Middle Hesse. Key implementation tasks in regional greenbelt policy have been delegated to a weakly institutionalised special purpose agency that has limited resources and authority, and municipalities have considerable autonomy in deciding on the implementation of greenbelt projects. My analysis reveals that tensions and coordination problems between the institutions and stakeholders in the Frankfurt Rhine-Main region, in part, result in the delegation of 
greenbelt planning to the local level. However, as these local initiatives cannot effectively manage regional growth, I argue that greenbelt planning needs to be upscaled to the regional level and requires proper institutional support with strong legislative protection.

Therefore, my research reveals that vertical coordination in both cases is not solely a top-down approach, but rather a complex combination of both top-down and bottom-up approaches. However, the direction and flow of coordination among policy levels varies, as it is strongly shaped by power asymmetries and is dependent on the political parties in power at that time, which ultimately influences greenbelt policy implementation.

Second to the issue of vertical coordination, my research shows that horizontal coordination among institutions and stakeholders at the same policy level strongly shapes greenbelt policy implementation. To begin with, my findings indicate that greenbelt policies in both cases have facilitated horizontal coordination among stakeholders, improving the governance of these greenspaces. In the Ontario case, the creation of greenbelt-related organisations has increased the opportunities for stakeholder participation, while many municipalities have developed partnerships with local organisations to further support policy implementation. In the Frankfurt case, the Regionalpark policies have been effective at uniting regional politicians around the goal of landscape protection. Therefore, my research demonstrates that greenbelt policies in both cases have increased governance capacity over time by strengthening stakeholder partnerships, improving greenbelt implementation.

At the same time, my findings illustrate that greenbelt implementation has been impacted by problems of horizontal coordination across diverse policy domains. Given that both regional greenspaces include several land-uses, each case's greenbelt policies intersect with plans from multiple institutions, including nature conservation authorities, transportation agencies, and other special purpose bodies. This complexity of inter-policy coordination creates considerable problems that can restrict policy implementation. For example, in the Ontario case, inconsistent language between the many GGH-specific policies related to their different land-use allowances and regulatory frameworks creates considerable challenges for local planners to interpret these plans. Thus, while the provincial government tried to reduce the conflicts between the plans during the 2015 policy review, local planners often make decisions based on their own municipal context. The Greenbelt Plan also allows for a wide variety of non-agricultural land-uses within the greenbelt, including major infrastructure projects, natural resource extraction and recreational activities. However, civil society groups argue that these activities undermine the environmental goals of this plan (Tomalty, 2012). 
In the Frankfurt case, the regional greenbelt agency shifted its mandate to tourism promotion from an initial focus on protecting the Regionalpark from development. By changing its mandate, the regional greenbelt agency undermined growth control policy goals, further limiting the Regionalpark's ability to serve as an effective regional greenbelt. Thus, my research shows that these horizontal coordination problems have resulted in inconsistent greenbelt policy implementation, and conflicting policy priorities.

Third, effective regional greenbelt implementation also requires territorial coordination across multiple municipal and special purpose bodies' jurisdictions. However, my research reveals that greenbelt policy implementation in both cases has been impacted by territorial coordination challenges related to institutional misfits, producing impacts far beyond these greenspaces' boundaries. Both case studies have overly complex regional institutional environments comprised of numerous government authorities along with a plethora of special purpose bodies that have different and partially overlapping territorial jurisdictions, which creates coordination problems, conflicts between stakeholders, and barriers to properly supporting greenbelt policy implementation.

As discussed in chapters 4 and 6 , due in part to challenges that the greenbelt agency faces in navigating the Frankfurt Rhine-Main region's institutional complexity, the development of park activities has been downscaled to the local level. However, I argue that this delegation of greenbelt policy implementation to municipalities' initiatives undermines the creation of a regional greenbelt, as these local small-scale projects are not designed to manage regional concerns. Likewise, as discussed in chapters 3, 5 and 6, in the Ontario case, the Greenbelt Plan has facilitated leapfrog development beyond the greenbelt's boundaries, according to multiple stakeholder groups. This lowdensity development in some suburban municipalities creates numerous problems that undermine effective greenbelt management. In contrast, leapfrog development is not seen in the Frankfurt Rhine-Main region for several reasons. First, the region lacks strong regional greenbelt regulations. Indeed, the Regionalpark is weakly protected through building and land-use restrictions under the regionalised land-use plan. Second, municipalities have large reserves of designated building land and Germany's national building code has recently even been liberalised to loosen the previous restrictions to residential greenfield development (Monstadt and Meilinger, 2020). As a result, there is considerably less pressure for leapfrog development in the Frankfurt Rhine-Main region than in the Ontario case. Despite these challenges, both cases show the importance of coordination across multiple territorial jurisdictions to ensure effective regional greenbelt implementation. 
In addition to my findings related to the three institutional dimensions, my research reveals that the institutional designs of greenbelt planning described above can make policy implementation vulnerable to local politics and changes in government agendas. In the Ontario case, the institutional arrangements safeguarding greenbelt protection are highly vulnerable to shifting political agendas at the provincial and municipal levels. As discussed above, municipal resistance and developers' influence on local councils can strongly undermine growth management practices. In addition, Ontario's provincial governments have a history of fluctuating involvement in regional planning (Frisken, 2001), with some governments weakening planning legislation to give developers more freedom in land-use planning matters. In the Frankfurt case, Regionalpark implementation can be vulnerable to the region's strong growth politics. As discussed in chapter 4, the inter-municipal spatial planning system has not contained suburban growth, while regional development patterns are strongly shaped by locational competition of municipalities for investment (Monstadt and Meilinger, 2020). In addition, the regional greenbelt agency has no spatial planning authority to confine regional growth. These factors, combined with the Regionalpark's weak policy protection in the regionalised land-use plan, make the park vulnerable to local self-interests. Thus, my research illustrates that greenbelt policies are highly susceptible to reform when political climates evolve, allowing politics to detract from achieving policy goals.

To conclude, regional greenbelt policies require policymakers to collaborate between policy levels, across policy domains and territorial jurisdictions, while also curtailing pro-growth interests. This coordination requires a high level of governance capacity. In both cases, I found many examples of leaders in all sectors who have strongly committed to greenbelt protection, as well as dedicated planners working behind the scenes to facilitate policy implementation. Despite these best efforts, the coordination problems resulting from the institutional designs of both greenbelts present serious challenges to overcome. This is a problem both in the Frankfurt Rhine-Main and GGH regions, known for their weak levels of inter-municipal cooperation on regional issues (Monstadt et al., 2012; Nelles, 2012). Therefore, from this comparative analysis, I conclude that both cases have produced mixed results in terms of achieving policy goals. While the Ontario case has more ambitious greenbelt policies that have been effective in stopping the conversion of farmland in the greenbelt, it has also stimulated leapfrog development. In the Frankfurt case, my research shows that the greenbelt agency is weakly institutionalised and the Regionalpark cannot function as an effective regional greenbelt. 


\subsection{SYNTHESIS OF KEY RESEARCH FINDINGS}

Based on the above answers to the first three research questions, this section and the subsequent address the main research question of the dissertation: how do institutional arrangements shape the governance of regional greenbelts, and how could these greenspaces be more effectively governed?

As outlined in chapter 6, a new generation of greenbelts has developed since the 1990s in planning practice. These contemporary greenbelts have multi-functional policy goals which often form major elements of integrated land-use planning frameworks designed to better manage regional growth. These recent greenbelts build on more flexible governance arrangements, with the private sector and civil society groups taking increased roles in policy implementation. However, the challenges discussed earlier in the conclusion raise questions about whether the existing institutional arrangements supporting these greenspaces can deliver on the ambitious policy goals of new generation greenbelts. My research reveals three examples of institutional problems that considerably hinder the ability of these institutional structures to effectively support regional greenbelt policy implementation.

First, while there is an increased focus on flexible institutional arrangements in regional governance debates, my research reveals several limitations to these institutional structures. As seen in the Frankfurt case, special purpose agencies can have limited authority and financial resources and may not be located at the most suitable spatial scale to effectively fulfil their mandate. In addition, regional greenbelt management requires strong authority over land-use planning matters to effectively contain suburban growth and protect greenspaces, which cannot be achieved by special purpose agencies. Thus, my research demonstrates that these flexible institutional arrangements, as seen in the Frankfurt case, do not necessarily improve regional greenbelt implementation.

Second, the existence of many special purpose agencies in urban regions with delegated responsibilities for a diversity of issues results in a complex mosaic of authorities with overlapping jurisdictions. This context creates what Young (2002) refers to as institutional misfits. However, as discussed above, these fragmented institutional arrangements found in both cases result in considerable coordination problems between stakeholders and produce unplanned outcomes, such as the leapfrog development seen in the Ontario context. These multi-layered territorialities associated with fragmented institutional arrangements create significant issues that undermine regional greenbelt implementation. 
Finally, despite the plethora of organisations responsible for regional public service delivery, institutional voids may result from these regional governance arrangements. In the Ontario case, an institutional void at the regional level has existed in the GGH region for decades, given that the provincial government has failed to create a regional governmental authority, instead taking on that role itself (Frisken, 2001). As a response, the provincial government created several GGH region-specific policies to provide municipalities additional guidance. However, this strategy has produced an overly complex policy environment, creating significant coordination problems for stakeholders, and ultimately impeding policy implementation. The above examples highlight the limitations of these institutional structures to effectively support regional greenbelt management. Therefore, I conclude that the existing institutional arrangements supporting new generation greenbelts cannot effectively deliver on their ambitious policy goals.

Relatedly, while my research focuses on how institutions shape regional greenbelt governance, it is important to note that this is not only a one-sided relationship, as stakeholders also influence institutions. Neo-institutional debates highlight this coevolutionary relationship between institutions and society (Smith, 2005), or structure and agency (Giddens, 1984). Indeed, evidence from both cases show how stakeholders have shaped institutions, particularly at the policy formation stage. In Ontario, the establishment of the GGH greenbelt was strongly influenced by civil society groups. Many of the activists who were successful in protecting the Oak Ridges Moraine were the driving force behind the GGH greenbelt's creation and influenced the decision of provincial politicians from the Liberal government to protect this greenspace. In the Frankfurt case, the establishment of the Frankfurt greenbelt was shaped by a participatory planning process initiated by city council and organised by the Frankfurt GreenBelt Project Office, including workshops with local and international experts, and a citizens' competition. The results from this process served as the basis for the formation of the municipal GreenBelt constitution, which protects this greenspace.

At the same time, my research also reveals that stakeholders have historically had fewer opportunities to influence institutions in these cases. This is particularly the case in Ontario's top-down government approach to greenbelt planning, given the provincial government's strong authority over municipalities and land-use planning matters. Therefore, while institutional arrangements play a strong role in shaping the governance of greenbelts, my research shows that these institutions are also produced and changed by stakeholders, reflecting institutional change in greenbelt governance. 
Besides these formal institutional structures, informal institutions such as traditions, culture, and identity also play an important role in shaping the governance of regional greenbelts. As seen in my research, residents often feel an increased sense of connection to greenbelts over time, which can translate into broad public support for these greenspaces. The strong support of the public is essential to the long-term success of a greenbelt, particularly if it is ever threatened by future developments or changes in political regimes. However, developing a strong sense of connection to regional greenbelts can be a challenge for residents, due in part to the vast territorial scope of these greenspaces. One challenge is the difficulty of accessing regional greenbelts, as they are partially only accessible by private vehicles, and many societal groups may thus have difficulties in experiencing regional greenspaces. Despite public education programs, these concerns provide a challenge to policymakers' efforts to build a strong regional identity based on regional greenbelts. For example, in the Frankfurt case, the Regionalpark is promoted in economic development strategies to attract business investment and enhance regional competitiveness, yet there is a lack of broader public awareness that the park exists. Therefore, these examples highlight the considerable role played by informal institutions in influencing regional greenbelt governance.

Finally, my research reveals strategies that would strengthen the governance of regional greenbelts. First, higher-level government authorities need to take a strong leadership role in managing regional greenbelts. Stakeholders such as environmentalists, developers, farmers, and municipalities often have conflicting interests related to greenbelts, so there is a need for higher levels of governments to exercise their authority to facilitate effective policy implementation. For example, if municipalities are resistant to implementing planning regulations, provincial or state governments can then enforce compliance mechanisms to ensure implementation. This leadership from higher levels of government must also be consistent over time and they must defend greenbelt policies at land-use planning tribunals, or against development interests. If higher-level governments fail to take a strong and consistent role in greenbelt planning and instead take a more hands-off approach, a broader regional vision risks becoming undermined by powerful interests over time. Second, there is a need to pay more attention to changes in local and regional growth politics, which play a considerable role in greenbelt governance. As discussed above, my research demonstrates that greenbelt governance is considerably influenced by local growth coalitions. However, growth politics are not static, and rather evolve over time. For example, changes in government often result in shifting political agendas swinging between pro-growth and growth control. Development practices also change over time as developers respond to market demands. Thus, policymakers need to be more aware of these evolving growth politics, which have a significant impact on greenbelt governance and can undermine effective policy implementation. 
Therefore, while the governance of regional greenbelts is complicated by the diversity of stakeholders involved in their management, my research shows several strategies that can improve how these greenspaces are governed. I will further reflect upon this discussion about greenbelt governance in the next section of the conclusion, which provides recommendations for policymakers.

To conclude, the GGH greenbelt and the Regionalpark RheinMain are tremendous assets that provide multiple environmental, economic, and social benefits for their regions' residents. However, my research reveals the difficulties of managing the complex interactions between the multiple institutions and stakeholders involved in regional greenbelt implementation in both cases, and the serious problems that result from this. These challenges prevent these greenspaces from completely achieving their ambitious policy goals. Therefore, I argue that new generation greenbelts require different institutional arrangements from those that their traditional predecessors had to ensure their effective governance. As a result, the next section will outline recommendations for institutional reforms to better manage new generation greenbelts.

\subsection{LESSONS FOR THE FUTURE GOVERNANCE AND PLANNING OF REGIONAL GREENBELTS}

In light of the above discussion, this section addresses the fourth research question: what lessons could be drawn for the future governance and planning of regional greenbelts? I provide seven key recommendations for policymakers about how the governance and planning of regional greenbelts could be improved. These suggestions include proposals for institutional reforms, and strategies that can be made to existing institutional frameworks that could improve greenbelt policy implementation.

First, one of the main conclusions of my research is that regional greenbelts require institutional reforms to effectively manage the governance challenges facing new generation greenbelts. In the Ontario case, a supra-regional agency would need to be established to fill the long-standing institutional void at the GGH level to coordinate regional land-use planning, including the Greenbelt and the GGH Growth Plan. The responsibility for coordinating regional transportation planning and preparing the transportation plan could also be incorporated into this supra-regional agency. This reform would assist with partially reducing institutional fragmentation and misfits, as the regional transportation agency, Metrolinx, operates with a different territorial scope than the GGH region (i.e. 
the Greater Toronto and Hamilton Area). ${ }^{35}$ However, Ontario has a long history of failed proposals for similar types of institutional reforms and regional agencies being disbanded such as the Greater Toronto Services Board (Nelles, 2012). For this reason, a supra-regional agency would need to be given sufficient authority, resources, and political support to achieve its objectives.

In the Frankfurt case, my research shows that the greenbelt agency is weakly institutionalised, and in its current form as a special purpose body cannot enforce effective regional greenbelt implementation. Therefore, regional greenbelt planning needs to be reintegrated back into the Regional Authority (Regionalverband FrankfurtRheinMain), which has the appropriate spatial and landscape planning authority for the Greater Frankfurt region. In addition, if the Regional Authority were to manage the Regionalpark, this could provide considerable synergies in implementing and aligning the growth management policy goals in the regionalised land-use plan. This reform seems feasible given that the park has a long history with the Regional Authority. The Regionalpark was initially managed by the Regional Authority's predecessor (the Planungsverband), and staff from the greenbelt agency and the Regional Authority already work together on planning for the park. Despite the challenges in making these reforms, the institutional structures supporting these regional greenbelts need to be revised to reflect the current complexity of the urban regions in which they are located in, so that these greenspaces can be more effectively governed.

Second, greenbelt policies need to be supported by other sectoral policies to form integrated frameworks and effectively address growth management efforts in urban regions. More specifically, greenbelt policies need to be complemented by regional growth and transportation plans, along with regional economic development policies. In the Ontario case, the Greenbelt Plan is supported by the GGH Growth Plan and a regional transportation plan, forming a comprehensive regional planning strategy. However, a regional economic development plan still needs to be developed for the GGH. Contrary to this, in the RhineMain region, a regional growth plan does not exist, while tax incentives and municipal and regional growth coalitions promote a system of intermunicipal competition for investment, stimulating municipalities to designate the maximum amount of building land allowed. In addition, while greenbelt policies have the potential to provide strong protection for farmland against development pressures, additional initiatives are needed to support farmers and ensure a sustainable agricultural sector. In the Ontario case, these recommendations include

35 The Greater Toronto and Hamilton Area forms the core urban and suburban areas of the larger GGH region and includes the cities of Toronto and Hamilton, and the regional municipalities of Peel, Halton, Durham, and York. 
training for municipal planners about farming issues, creating programmes to support local food production, improving communication between provincial and municipal staff about agricultural interests and diversification strategies to enhance farm viability, such as agritourism (Caldwell and Proctor, 2013). While establishing a greenbelt provides an excellent first step towards protecting farmland and nature conservation areas, support from other sectoral plans, government programmes and planning staff at all policy levels is needed to effectively achieve that policy goal.

Third, monitoring of greenbelt policies by a government authority needs to be strengthened to assess effectiveness in achieving the policy objectives of greenbelts. Civil society groups, research institutes and foundations often conduct monitoring of greenbelt policies. In the Ontario case, organisations such as Environmental Defence and the Neptis Foundation take a proactive role in monitoring greenbelt policies by providing information to the public about plan implementation problems. Similarly, in the Frankfurt case, greenbelt policy monitoring and educational activities are provided by environmental groups such as BUND (Bund für Umwelt- und Naturschutz e.V. or Federation for Environment and Nature Conservation) and NABU (Naturschutzbund Deutschland e.V. or German Association for Nature Conservation). However, for independence purposes, a higher-level government authority should have the main responsibility for overseeing monitoring and evaluation of policy implementation. Greenbelt policies should be evaluated according to performance criteria, and to ensure that the process is transparent, the data should be made publicly accessible online.

Based on such evaluations, greenbelt policies should be updated regularly to reflect changing regional conditions and shifts in land-use planning discourses. In Ontario for example, the 2017 Greenbelt Plan was revised to include issues such as climate change, green infrastructure, and ecosystem services in the planning of the greenbelt. However, this is a matter that could be improved in the Frankfurt case, as greenbelt and landscape planning policies are not monitored by governments, are outdated, and need to be revised. For example, while the Frankfurt GreenBelt constitution was adopted in 1991, no revised policies have been approved since then. The landscape plan at the state level in Hessen is from 2000, and my research indicates that there are no plans to update those policies. However, the Regional Authority has started to update their 2001 landscape plan. Moreover, in the case that greenbelt policies are supported by complementary policies, such as regional growth plans, policymakers should review and update these policies together. In the Ontario case, for example, the provincial government conducted a coordinated policy review in 2015 of the Greenbelt Plan, the GGH Growth Plan, the Niagara Escarpment Plan, and the Oak Ridges Moraine Conservation Plan. Through this coordinated review, provincial staff were able to create more consistent language and reduce the contradictions between these plans, which ultimately will improve policy implementation. 
Fourth, greenbelt policy implementation needs to be strongly supported by civil society initiatives, including environmental organisations, residents' associations, and foundations. These stakeholder groups provide important functions, including raising public awareness about greenbelts through their educational programmes, monitoring policy implementation, and publicising details about threats to these greenspaces' protection. This is an issue that could be improved in the Frankfurt case, as the localised nature of environmental groups in the Frankfurt Rhine-Main region results in their limited engagement with regional concerns. Thus, there is a need for regional collaboration of these local environmental groups to support regional greenbelt policy implementation more effectively. An additional improvement in the Frankfurt case would be for the regional greenbelt agency to expand its partnerships beyond its focus on tourism promotion, and to more actively engage with environmental, agricultural and forestry organisations that have, at least in part, similar goals to support Regionalpark implementation.

Fifth, there is a need to coordinate growth management policies across urban regions to prevent leapfrog development. As mentioned earlier in the conclusion, this type of development does not occur in the case of the Frankfurt Rhine-Main region. In contrast, the Ontario case demonstrates that this form of low-density growth has significant negative impacts that undermine greenbelt policy implementation. While the GGH Growth Plan provides an excellent first step to address regional growth concerns, additional strategies could improve the situation. By banning or regulating the foreign ownership of farmland and land purchases made by pension funds, the provincial government could reduce a portion of the land speculation activities driven by development interests occurring beyond the greenbelt. Such restrictions have been implemented in the Canadian provinces of Saskatchewan and Manitoba and regulating these speculative practices could assist with partially reducing the intense suburbanisation pressures put on the greenbelt. Furthermore, the expansion of roadways and highways can facilitate leapfrog development, which can have significant negative environmental impacts, so the creation and expansion of transportation infrastructure should be avoided within the greenbelt. If that is not possible, then measures should be taken to limit the harmful impacts of proposed transportation projects (Tomalty, 2012). In addition, there is also a need for policies to address housing affordability concerns in communities south of the GGH greenbelt, as these problems are driving residents to seek cheaper housing options in more remote areas, further fuelling leapfrog development (Tomalty and Komorowski, 2011).

Sixth, a long-term perspective is needed in developing greenbelts. Greenbelt policies aim to redirect deeply entrenched low-density development practices, and as such, their implementation often generates resistance from stakeholders. As seen in the Ontario case, it has taken years to overcome the initial opposition of municipalities, developers 
and farmers to the Greenbelt and Growth Plans. Some members of these stakeholder groups are still resistant to implementing these policies. Similarly, in the Frankfurt case, the initial resistance of farmers to participate in Regionalpark activities has subsided over time. However, foresters still have limited involvement with the Regionalpark. In addition, it can take years to see the results of growth management policies on the ground, as it takes time for developers and municipalities to shift their practices. In the Ontario case, for example, large supplies of land were also allocated for urbanisation in the GGH region before the Greenbelt and Growth Plans were introduced, as municipalities are required to keep a supply of land for future development (Burchfield, 2016). These land supplies would have been allocated in the context of less ambitious policies with lower density targets than required by the Growth Plan, and that land could still be developed in the future based on these old policies (ibid.). Similarly, in the Frankfurt case, municipalities often have large designated land reserves resulting from approvals under older land-use and zoning plans, which can undermine efforts to contain suburbanisation (Monstadt and Meilinger, 2020). Thus, my research reveals that it can take years to accurately assess if planning objectives have been effectively achieved or not, given the long-term planning horizons of growth management policies such as greenbelts.

Finally, from a broad perspective, the current trends in suburban growth and the institutional arrangements shaping and promoting this development requires a profound reassessment. Indeed, considerable literature has documented how low-density development in suburban areas results in a range of problems including the destruction of farmland and natural areas, air pollution and rising infrastructure provision costs (Deal and Schunk, 2004; Frenkel, 2000). As a result, planning ambitions have evolved in recent decades to include a focus on sustainability and intensification, while governments have incorporated smart growth or compact city principles into their land-use planning policies (Grant, 2009; Westerink et al., 2013). Despite these shifts in policy ambitions and discourses, a key problem is the current trend towards low-density, sprawling growth patterns. The suburban land market is strongly shaped by the economic incentives tied to the continued development of greenfields, encouraging the formation of growth coalitions composed of developers, real estate investors and local governments (Harris and Lehrer, 2018; Logan and Molotch, 1987). Thus, developers make huge profits from buying and reselling land, while municipalities benefit from development charges or land transfer taxes associated with new growth (Harris and Lehrer, 2018). Therefore, this situation raises questions about the long-term viability of ever-increasing low-density suburban growth.

Thus, I argue that greenfield development needs to be given a value that reflects the scarcity and environmental value of land, which would stimulate municipalities and developers to change their development practices. A problem is that the price that actors pay to develop 
land externalises the long-term societal and environmental costs of land consumption (Nuissl and Schroeter-Schlaak, 2009). One strategy is to apply market-based instruments to curb the effects of excessive land consumption, which allocate more of the external costs associated with development on those responsible for it and reduce economic incentives of further decentralised development (ibid.). Economic instruments can be used either to make land development more costly for the actors involved or can increase the expense of residing in new developments, such as through taxes, subsidies, or tradeable development permit schemes (ibid.). In the Frankfurt case, tradable development permit schemes, a system to control development by setting the amount of open space loss through permits that are traded between municipalities, could provide for a more efficient allocation of land-use rights on greenfields (Henger and Bizer, 2010). In the Ontario case, development charges need to be reformed to permit municipalities to charge developers for the full costs related to new development (Burda et al., 2012) ) $^{36}$. Development charges are used by municipalities to pay for the capital costs of growth, but they have long been criticised for subsidising low-density development and preventing municipalities from recovering the true value of growth including the environmental costs (ibid.). Therefore, market-based instruments could provide powerful incentives to redistribute the costs of development and benefits of greenfield preservation more evenly amongst stakeholders (Nuissl and Schroeter-Schlaak, 2009).

\subsection{INSIGHTS FOR ACADEMIC DEBATES}

A longstanding academic debate discusses which regional institutional arrangement is the most suitable to address regionalisation processes and regional policy concerns. Three distinct approaches have therefore dominated the literature: the metropolitan reform model, the public choice school, and new regionalism (Glass, 2018; Nelles, 2012; Savitch and Vogel, 2000). Based on these three institutional models, my research provides the following three insights about the governance of regional greenbelts from an institutional perspective.

First, scholars of the metropolitan reform model argue that government consolidation through amalgamation or annexation will reduce institutional fragmentation and that overarching governments are more effective at delivering public services that cross municipal authorities and require inter-municipal collaboration (Nelles, 2012; Savitch and Vogel,

36 Development charge reforms were approved in January 2020 under the More Homes, More Choices Act, 2019. At the time of writing, it is unclear what are the implications of these reforms given that municipalities have not yet adopted these policies. 
2000). My research indicates that higher levels of government are indeed more effective at coordinating policy implementation and addressing regional concerns, such as urban sprawl and environmental problems. Effective greenbelt policy implementation requires the allocation and reallocation of land-use rights against the resistance of municipalities and developers. Higher levels of government have the strong planning authority to control regional growth and can enforce compliance mechanisms if municipalities are resistant to implementing planning restrictions. While flexible institutional arrangements have become increasingly popular in academic discourses (Heley, 2013), my research shows that regional greenbelt planning needs to be under the jurisdiction of high level government authorities to effectively address the complex challenges involved in new generation greenbelt management.

Second, the public choice approach advocates that market forces and strong locational competition are more efficient in service delivery than state activities and enable different autonomous localities to engage in voluntary instead of forced cooperation where necessary (Glass, 2018; Nelles, 2012). However, as my research demonstrates, market forces and the increasing institutional fragmentation found in urban regions poses serious problems that hinders effective regional greenbelt management. In the Frankfurt case, there is intense locational competition between municipalities, which compete for business taxes, infrastructure investments, and to attract new residents. This intermunicipal competition strongly shapes suburban growth patterns and undermines planning authorities' attempts to implement regional smart growth policies (Monstadt and Meilinger, 2020). Thus, my research findings show the opposite of the claim of public choice scholars about the increased efficiency resulting from inter-municipal competition, as this institutional arrangement creates significant issues that undermine effective greenbelt policy implementation. In contrast, my research shows that developer-driven growth politics are occurring beyond the greenbelt in the Ontario case, as local growth coalitions push to continue low-development practices in some suburban municipalities. While municipalities may want this development to occur in their jurisdictions, the intense inter-municipal competition is more restricted in the German context. For example, Ontario municipalities have limited authority to create incentives that would attract new investment. Therefore, the public choice model is less applicable to the conditions found in the Ontario case.

One additional current problem with the public choice model is that land markets do not appropriately reflect the negative externalities resulting from land consumption and scarcity of land. In suburban land markets, economic incentives for municipalities and developers continue to stimulate investment in decentralised, low-density development. However, as discussed earlier, if market-based instruments were introduced that consistently 
internalised environmental costs of greenfield development, reallocated those costs to developers, homeowners and municipalities and incentivised densification, brownfield redevelopment and smart growth, then a stronger reliance on market mechanisms, as advocated by the public choice model, could be effective in greenbelt development. However, given the current land market conditions, the effectiveness of the public choice model in growth confinement and greenbelt development shows clear limitations.

Third, new regionalism emphasises that effective regional governance does not need institutional consolidation, but rather can be achieved through regional collaborative arrangements, including public-private or inter-municipal partnerships and voluntary networks (Glass, 2018; Nelles, 2012). However, my research indicates that there are difficulties associated with these collaborative and voluntary arrangements that impact growth management efforts. Regional growth control requires the more efficient allocation and reallocation of land-use rights, which creates conflicts between the economic development interests of municipalities and developers. However, these redistributional policies cannot be effectively implemented through collaborative and voluntary arrangements. As seen in the Frankfurt case, the regional greenbelt agency can only encourage stakeholder cooperation and has no planning authority to control regional growth. In addition, the increased delegation of public service provision to multiple special purpose bodies increases institutional fragmentation, which can hinder effective coordination between stakeholders. Therefore, my research reveals that the collaborative and voluntary mechanisms advocated by new regionalists have significant limitations and may even increase institutional complexity, which undermines effective greenbelt governance.

In addition, while new regionalists advocate cooperation as a strategy to attain regional governance, my research indicates that achieving stakeholder cooperation can be an overly complex process. Similar to Nelles (2013), my research indicates that multiple factors that can encourage or constrain cooperation between stakeholders, affecting greenbelt policy implementation. As stated earlier, greenbelt policies in both cases have allowed for the creation of better governance practices by providing new opportunities for partnerships. However, asymmetrical power relations can also shape cooperation among stakeholders. As seen in both cases, conflicts occur vertically among stakeholders at multiple policy levels and horizontally among municipalities in each region. Institutional capacity is another factor that shapes stakeholder cooperation. For example, Frankfurt's regional greenbelt agency has limited resources, influencing their staff's ability to collaborate with other regional organisations on park projects. Therefore, while new regionalists see cooperation as a more flexible response to address regional problems, my research indicates that cooperation alone may not be enough to achieve effective greenbelt governance. 
To conclude, my research shows that under the current regulatory and market conditions, a combination of all three institutional models could lead to more effective regional governance of greenbelts. Thus, strong involvement of higher-level government authorities is required to effectively design, implement, and monitor regional greenbelt policies, corroborating many assumptions of the metropolitan reform model. At the same time, the collaborative arrangements, or public-private partnerships, as advocated by new regionalism, also play a role in supporting greenbelt policy implementation. However, the effectiveness of collaborative arrangements in reallocating and confining land use is restricted, since win-win solutions are often not possible, and the necessary confinement of growth creates winners and losers. Relying on market mechanisms and locational competition, as advocated by the public choice model, undermines effective growth confinement initiatives under the current market conditions. Yet, if land prices more accurately reflected the external costs of land consumption through the use of economic instruments - such as through taxation of greenfield development - and if municipalities were compensated for abstaining from greenfield development - for example, through transferable development rights or tradable development permit schemes - market mechanisms could play an effective role in more efficiently allocating land use rights. The introduction of market-based instruments could thus complement the growth confinement efforts by senior government authorities, as well as those by collaborative arrangements or public-private partnerships. Thus, rather than how it is presented in much of the literature, the metropolitan reform model, new regionalism, and the public choice school are not necessarily exclusive but should be synergistically combined to foster more effective regional greenbelt governance.

\subsection{DIRECTIONS FOR FUTURE RESEARCH}

This research leads to several new insights for both academic and policy debates about how these regional greenbelts could be more effectively governed. However, the focus of my research did not allow for the examination of other relevant topics for greenbelt governance. Therefore, this section provides five recommendations for future research related to greenbelt governance.

First, an avenue for future research is to explore how the political economies of suburbanisation influence greenbelt management. Capital accumulation plays a significant role in influencing development in suburban areas and in shaping the governance practices of the associated stakeholders (Ekers et al., 2012). Local growth coalitions including developers, real estate investors and local politicians often facilitate the continuation of low-density development practices, and these growth politics are key to understanding 
the role of capital in suburbanisation (Logan and Molotch, 1987; MacDermid, 2006). In addition, in recent decades, new configurations of regional economic activities have emerged, as industrial and commercial firms have relocated to suburban areas due to tax incentives or cheaper land rents. However, these developments can have a significant impact on greenbelts. For example, the creation or expansion of suburban infrastructures needed to serve these areas can result in the destruction of natural areas. Therefore, further research that takes a political economy perspective could explain how the political economies of suburbanisation impact effective greenbelt policy implementation.

Second, another area for future research is to focus on the economic value of greenbelts. Beyond the environmental benefits provided by greenbelts, these greenspaces provide essential ecosystem services and economic benefits that support local and regional economies. These ecosystem services play a key role in climate change mitigation and adaptation through storing greenhouse gases, controlling against floods, and protecting natural habitats for endangered species (Tomalty, 2012). Furthermore, these greenspaces provide significant investment and employment opportunities in agricultural production, nature conservation, forestry, tourism, recreation, and aggregate extraction (Econometric Research Limited, 2012). It is important for policymakers to recognise the ecosystem services and other economic benefits of greenbelts, because without strong policy protection and other government support, these economic benefits cannot be efficiently utilised. Despite the importance of this issue, these economic benefits are not widely discussed in academic debates and need to be explored in future research projects.

Third, future research could explore market-based mechanisms to address the economic incentives tied to continuing low-density urban and suburban growth. Under the current market conditions, my thesis indicates strong limits to regional government authorities' efforts to effectively contain low-density development, given the huge profits associated with developing greenfields. Thus, market-based instruments could reflect the scarcity of land and stimulate municipalities and developers to change their practices. However, while these market-based instruments are seen as having potential to tackle the problem of excessive land consumption, they are not widely used and are often applied only for time restricted initiatives (Fertner et al., 2016). In addition, while some projects address land-use changes through economic instruments in the American and European contexts (Henger and Bizer, 2010; McConnell et al., 2006), there is limited empirical evidence of their effectiveness. Thus, future research is necessary to understand the opportunities and limitations of collaborative arrangements, the potential of progressive market-oriented mechanisms to signal the scarcity of land to municipalities, developers and homeowners, and how they could be combined with state planning and collaborative arrangements. 
Fourth, similar to Taylor (2019), one area of future research is to examine how greenbelt planning might be implemented in countries in the Global South. There has been limited applicability of the greenbelt concept outside of North America, Europe, Australia, and China, with exceptions in India and Nairobi. Greenbelt planning in countries in the Global North is based on institutional arrangements that usually entails strong government authority for land-use planning and nature conservation, which allows for more effective policy implementation. However, how would greenbelt planning work in countries with vastly different institutional structures, an enormous pace of urbanisation and suburbanisation, and more informal systems of land use? Thus, future research could explore the experiences of greenbelt planning in countries of the Global South and to understand what modifications would be needed to make this planning concept more applicable to these vastly different conditions.

Finally, the focus of my dissertation is about how institutions shape the governance of regional greenbelts. However, this perspective can be shifted to conduct further studies on how institutions are produced and changed by actors, and how that institutional change occurs over the long term. Stakeholders can play a significant role in shaping greenbelt planning at all stages of the policy cycle including agenda setting, formulation, adoption, implementation, and evaluation. For example, civil society groups can strongly protest against the destruction of nature areas for new development, which may prompt governments to introduce legislation establishing a greenbelt. In addition, developers, and municipalities may be resistant to implementing greenbelt policies, which may cause higher levels of governments to reform this legislation. Therefore, it is important to examine the considerable role that these stakeholders have in changing institutional arrangements that restrict or support greenbelt implementation, as it can lead to a greater understanding of how these greenspaces might be more effectively governed. In addition, given the obduracy and path dependency of institutions, institutional change processes driven by decision makers and societal stakeholders often happen over long periods of time. Thus, future research also needs to examine long-term institutional change related to greenbelt planning, with greenbelts introduced before 1990 serving as the case studies. Using these well-established greenbelts, it is possible to examine how the institutional arrangements supporting these greenspaces have changed over several decades. However, actor-driven institutional change that occurs over long-time spans is not a topic that is well reflected in greenbelt debates. These long-established cases can provide valuable insights for policymakers that can be used to improve new generation greenbelt implementation. These lessons are important for policymakers, so that these greenbelts can be better governed in the future to continue providing the essential environmental assets needed for urban regions. 


\subsection{REFERENCES}

Aguado, I., Barrutia, J. M., \& Echebarria, C. (2017). Greenbelts: Some European experiences. Boletin de la Asociación de Geografos Españoles, (73), 463-467.

Allen, A. (2014). Peri-urbanization and the political ecology of differential sustainability. In Parnell, S. and Olfield, S. (Eds.). Routledge handbook on cities of the Global South. (pp. 522-38). New York, NY: Routledge.

Amati, M. (Ed.). (2008). Urban green belts in the twenty-first century. Hampshire, England: Ashgate.

Burda, C., Allan, T., Dunn, B., Linter, A., McClenagahan, T., Zizzo, L. (2012). Live where you go: Encouraging location-efficient development in Ontario. The Pembina Institute. Retrieved from https://www.pembina.org/reports/live-where-you-go.pdf

Burchfield, M. (2016). Province must embrace its role as regional planner for growth plan to succeed. The Neptis Foundation. Retrieved from http://www.neptis.org/latest/news/province-mustembrace-its-role-regional-planner-growth-plan-succeed

Burton, W. (2016). From greenspace to greenbelt: The role of civil society in landscape protection in the Toronto region. (Unpublished doctoral dissertation). University of Toronto, Toronto, Canada.

Caldwell, W. and Proctor, K. (2013). Farming in Ontario's greenbelt: Possibility grows here. Friends of the Greenbelt Foundation. Retrieved from https://www.greenbelt.ca/farming_in_ontario_s_ greenbelt_possibility_grows_here

Carter-Whitney, M. (2010). Ontario's greenbelt in an international context. Friends of the Greenbelt Foundation. Retrieved from https://www.greenbelt.ca/ontario_s_greenbelt_in_an_ international_context2010

Deal, B., \& Schunk, D. (2004). Spatial dynamic modelling and urban land use transformation: A simulation approach to assessing the costs of urban sprawl. Ecological Economics, 51(1-2), 7995.

Econometric Research Limited. (2012). Evaluating the economic benefits of greenbelt assets. Friends of the Greenbelt Foundation. Retrieved from https://www.greenbelt.ca/evaluating the_economic_benefits_of_greenbelt_assass

Ekers, M., Hamel, P., \& Keil, R. (2012). Governing suburbia: Modalities and mechanisms of suburban governance. Regional Studies, 46(3), 405-422.

Fertner, C., Jørgensen, G., Nielsen, T. A. S., \& Nilsson, K. S. B. (2016). Urban sprawl and growth management-drivers, impacts and responses in selected European and US cities. Future Cities and Environment, 2(1), 9 .

Frenkel, A. (2004). The potential effect of national growth-management policy on urban sprawl and the depletion of open spaces and farmland. Land Use Policy, 21(4), 357-369.

Frisken, F. (2001). The Toronto story: Sober reflections on fifty years of experiments with regional governance. Journal of Urban Affairs, 23(5), 513-541.

Giddens, A. (1984). The constitution of society. Cambridge, England: Polity.

Glass, M. R. (2018). Navigating the regionalism-public choice divide in regional studies. Regional Studies, 52(8), 1150-1161.

Grant, J. (2009). Theory and practice in planning the suburbs: Challenges to implementing new urbanism, smart growth, and sustainability principles. Planning Theory \& Practice, 10(1), 11-33.

Han, A. T., \& Go, M. H. (2019). Explaining the national variation of land use: A cross-national analysis of greenbelt policy in five countries. Land Use Policy, 81, 644-656. 
Harris, R., and Lehrer, U. (2018). The suburban land question: Introduction. In Harris R. and Lehrer, U. (Eds.). The suburban land question. A global survey. (pp. 3-42). Toronto, ON: University of Toronto Press.

Heley, J. (2013). Soft spaces, fuzzy boundaries and spatial governance in post-devolution Wales. International Journal of Urban and Regional Research, 37(4), 1325-1348.

Henger, R., \& Bizer, K. (2010). Tradable planning permits for land-use control in Germany. Land Use Policy, 27(3), 843-852.

Heynen, N. (2014). Urban political ecology I: The urban century. Progress in Human Geography, 38(4), 598-604.

Heynen, N., Kaika, M., \& Swyngedouw, E. (2006). Urban political ecology: Politicizing the production of urban natures. In Heynen, N., Kaika, M., \& Swyngedouw, E. (Eds.) In the nature of cities: Urban political ecology and the politics of urban metabolism. (pp. 1-19). London, England: Routledge.

Keil, R. (2018). Suburban planet: Making the world urban from the outside in. Cambridge, England: Polity Press.

Kortelainen, J. (2010). The European green belt: Generating environmental governance-reshaping border areas. Quaestiones Geographicae, 29(4), 27-40.

Logan, J. R., \& Molotch, H. L. (2007). Urban fortunes: The political economy of place. Berkeley, CA: University of California Press.

MacDermid, R. (2006). Funding municipal elections in the Toronto region. Paper presented at the Annual General Meetings of the Canadian Political Science Association, Toronto, Canada.

Mace, A. (2018). The metropolitan green belt, changing an institution. Progress in Planning, 121, 1-28.

McConnell, V., Kopits, E., \& Walls, M. (2006). Using markets for land preservation: Results of a TDR program. Journal of Environmental Planning and Management, 49(5), 631-651.

Monstadt, J. and Meilinger, V. (2020). Governing suburbia through regionalized land-use planning? Experiences from the Greater Frankfurt region. Land Use Policy. 91.

Monstadt, J., Zimmermann, K., Robischon, T. \& Schönig, B. (2012). Die diskutierte region. Probleme und planungsansätze der metropolregion Rhein-Main. Frankfurt am Main. Germany: CampusVerlag.

Nelles, J. (2012). Comparative metropolitan policy: Governing beyond local boundaries in the imagined metropolis. London, England: Routledge.

Nelles, J. (2013). Cooperation and capacity? Exploring the sources and limits of city-region governance partnerships. International Journal of Urban and Regional Research, 37(4), 1349-1367.

Nuissl, H., \& Schroeter-Schlaack, C. (2009). On the economic approach to the containment of land consumption. Environmental Science \& Policy, 12(3), 270-280.

Pond, D. (2009). Institutions, political economy and land-use policy: Greenbelt politics in Ontario. Environmental Politics, 18(2), 238-256.

Röhring, A., \& Gailing, L. (2005). Institutional problems and management aspects of shared cultural landscapes: Conflicts and possible solutions concerning a common good from a social science perspective. Leibniz-Institut für Regionalentwicklung und Strukturplanung eV (IRS). Leipzig, Germany.

Savitch, H. V., \& Vogel, R. K. (2000). Introduction: Paths to new regionalism. State and Local Government Review, 32(3), 158-168.

Smith, M. (2005). Institutionalism in the study of Canadian politics: The English-Canadian Tradition. In Lecours, A. (Ed.). New institutionalism: Theory and analysis. (pp. 101-127). Toronto, ON: University of Toronto Press. 
Swyngedouw, E. (2004). Social power and the urbanization of water: Flows of power. Oxford, England: Oxford University Press.

Swyngedouw, E., \& Heynen, N. C. (2003). Urban political ecology, justice and the politics of scale. Antipode, 35(5), 898-918.

Taylor, L. (2019). The future of green belts. In Scott, M., Galant, N. and Gkartzios, M. (eds). Routledge companion to rural planning. ( $1^{\text {st }}$ ed.). (pp. 458-468). New York, NY: Routledge.

Tomalty, R. (2012). Carbon in the bank: Ontario's greenbelt and its role in mitigating climate change. David Suzuki Foundation. Retrieved from https://davidsuzuki.org/science-learning-centrearticle/carbon-bank-ontarios-greenbelt-role-mitigating-climate-change/

Tomalty, R. and Komorowski, B. (2011). Inside and out: Sustaining Ontario's greenbelt. Friends of the Greenbelt Foundation. Retrieved from http://www.greenbelt.ca/inside_and_out_sustaining_ ontario_s_greenbelt2011

Wachsmuth, D. (2012). Three ecologies: Urban metabolism and the society-nature opposition. The Sociological Quarterly, 53(4), 506-523.

Wekerle, G. R., Sandberg, L. A., Gilbert, L., \& Binstock, M. (2007). Nature as a cornerstone of growth: Regional and ecosystems planning in the Greater Golden Horseshoe. Canadian Journal of Urban Research, 16(1), 20-38.

Westerink, J., Haase, D., Bauer, A., Ravetz, J., Jarrige, F., \& Aalbers, C. B. (2013). Dealing with sustainability trade-offs of the compact city in peri-urban planning across European city regions. European Planning Studies, 21(4), 473-497.

While, A., Jonas, A. E., \& Gibbs, D. (2004). The environment and the entrepreneurial city: Searching for the urban 'sustainability fix' in Manchester and Leeds. International Journal of Urban and Regional Research, 28(3), 549-569.

Young, O. R. (2002). The institutional dimensions of environmental change: Fit, interplay, and scale. London, England: MIT Press.

Zimmermann, K., Galland, D. and Harrison, J. (Eds.). (2020). Metropolitan regions, planning and governance. Cham, Switzerland: Springer. 


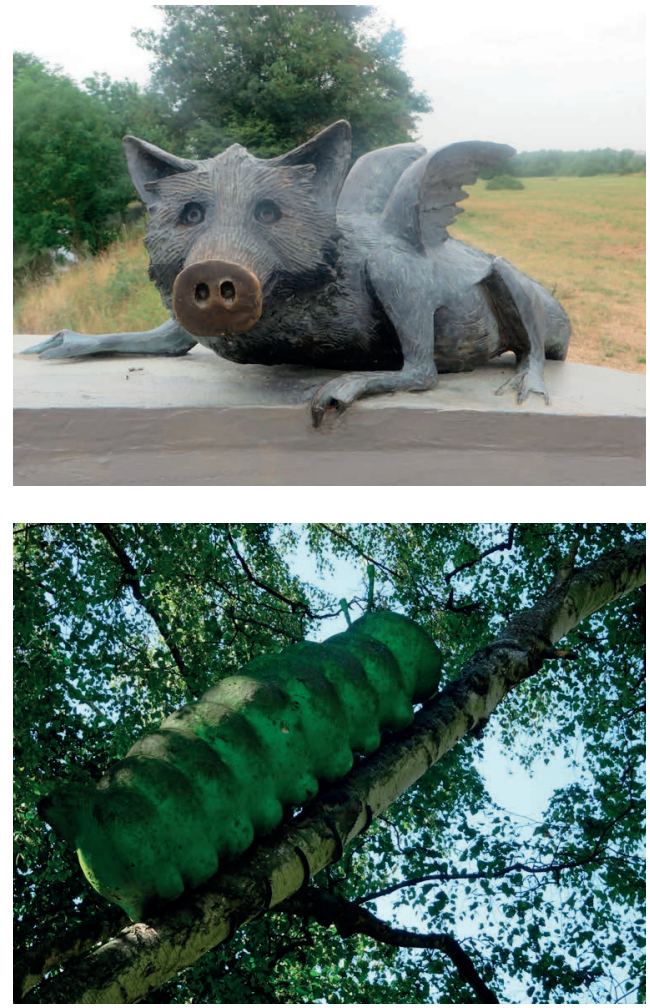

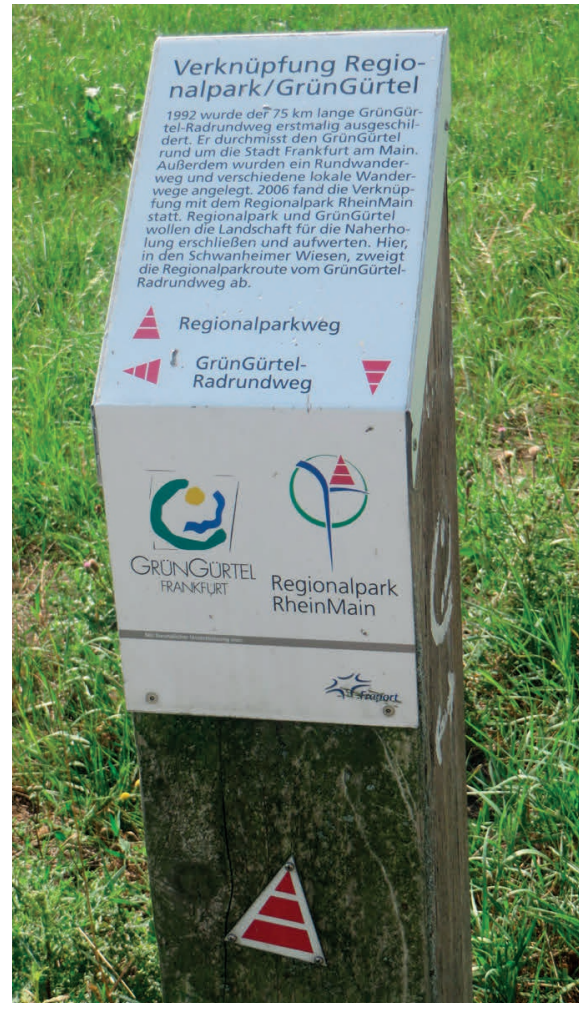

Art installations in the Frankfurt greenbelt: GreenBelt animal (top left), caterpillar (bottom left). Route signage within the Frankfurt greenbelt.

Source: author 


\section{Appendices}

Appendix A

Appendix B

Summary

Samenvatting

Curriculum Vitae

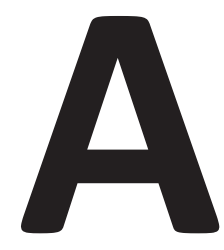





\section{APPENDIX A:}

\section{LIST OF INTERVIEWS FOR THE ONTARIO CASE}

\begin{tabular}{|c|c|c|c|c|}
\hline $\begin{array}{l}\text { Interview } \\
\text { No. }\end{array}$ & Position Title & Organization & Date & $\begin{array}{l}\text { Type of } \\
\text { Interview }\end{array}$ \\
\hline 1 & Politician & Town of Caledon & $13-08-2014$ & Face to face \\
\hline 2 & Manager & $\begin{array}{l}\text { GGH Region Environmental } \\
\text { Organization }\end{array}$ & $11-08-2014$ & Phone \\
\hline 3 & Member & $\begin{array}{l}\text { GGH Region Environmental } \\
\text { Organization and the Greenbelt } \\
\text { Council }\end{array}$ & 10-09-2014 & Face to face \\
\hline 4 & $\begin{array}{l}\text { Senior Staff } \\
\text { Member }\end{array}$ & $\begin{array}{l}\text { Ontario Farming } \\
\text { Organization }\end{array}$ & $27-08-2014$ & Phone \\
\hline 5 & $\begin{array}{l}\text { Manager and } \\
\text { Farmer }\end{array}$ & $\begin{array}{l}\text { GGH Region Environmental } \\
\text { Organization, Owns Farm in Brant } \\
\text { County }\end{array}$ & 19-08-2014 & Face to face \\
\hline 6 & Manager & $\begin{array}{l}\text { GGH Region } \\
\text { Environmental } \\
\text { Organization }\end{array}$ & 19-08-2014 & Face to face \\
\hline 7 & Politician & Town of Ajax & 20-08-2014 & Face to face \\
\hline 8 & $\begin{array}{l}\text { Two Staff } \\
\text { Members: } \\
\text { Director and } \\
\text { Manager }\end{array}$ & $\begin{array}{l}\text { Planning Policy, } \\
\text { Region of Halton }\end{array}$ & $19-08-2014$ & Face to face \\
\hline 9 & Policy Analyst & $\begin{array}{l}\text { GGH Region Farming } \\
\text { Organization }\end{array}$ & $26-08-2014$ & Phone \\
\hline 10 & $\begin{array}{l}\text { Two Staff } \\
\text { Members: } \\
\text { Manager and } \\
\text { Planner }\end{array}$ & $\begin{array}{l}\text { GGH Region } \\
\text { Conservation Authority }\end{array}$ & $27-08-2014$ & Face to face \\
\hline 11 & Politician & City of Oshawa & 10-09-2014 & Face to face \\
\hline 12 & $\begin{array}{l}\text { Freelance } \\
\text { Consultant }\end{array}$ & $\begin{array}{l}\text { GGH Region Environmental } \\
\text { Organization }\end{array}$ & $1-10-2014$ & Face to face \\
\hline 13 & Manager & $\begin{array}{l}\text { Economic Development and } \\
\text { Planning, City of Hamilton }\end{array}$ & $15-10-2014$ & Face to face \\
\hline 14 & $\begin{array}{l}\text { Senior Staff } \\
\text { Member }\end{array}$ & $\begin{array}{l}\text { GGH Region } \\
\text { Non-governmental } \\
\text { Organization (Aggregate } \\
\text { Resources) }\end{array}$ & $15-10-2014$ & Face to face \\
\hline
\end{tabular}




\begin{tabular}{|c|c|c|c|c|}
\hline $\begin{array}{l}\text { Interview } \\
\text { No. }\end{array}$ & Position Title & Organization & Date & $\begin{array}{l}\text { Type of } \\
\text { Interview }\end{array}$ \\
\hline 15 & $\begin{array}{l}\text { Politician and } \\
\text { Farmer }\end{array}$ & Town of Lincoln & 8-10-2014 & Phone \\
\hline 16 & Coordinator & $\begin{array}{l}\text { GGH Region Farming } \\
\text { Organization }\end{array}$ & $14-10-2014$ & Phone \\
\hline 17 & Lawyer & Environmental Law Firm & 28-10-2014 & Face to face \\
\hline 18 & Manager & $\begin{array}{l}\text { Ontario Ministry of } \\
\text { Municipal Affairs and } \\
\text { Housing }\end{array}$ & $30-3-2015$ & Face to face \\
\hline 19 & Manager & $\begin{array}{l}\text { Ontario Ministry of } \\
\text { Municipal Affairs and } \\
\text { Housing }\end{array}$ & $3-2-2015$ & $\begin{array}{l}\text { Face to face } \\
\text { (Follow up to } \\
\text { interview \#18) }\end{array}$ \\
\hline 20 & $\begin{array}{l}\text { Senior Staff } \\
\text { Member }\end{array}$ & $\begin{array}{l}\text { National Farming } \\
\text { Organization, Ontario } \\
\text { Division }\end{array}$ & $3-2-2017$ & Phone \\
\hline 21 & Staff Member & The Neptis Foundation & $15-2-2017$ & Phone \\
\hline 22 & Professor & $\begin{array}{l}\text { University of Northern } \\
\text { British Columbia }\end{array}$ & 8-3-2017 & Phone \\
\hline 23 & Planner & $\begin{array}{l}\text { Planning and Development } \\
\text { Department, County of Brant }\end{array}$ & $14-3-2017$ & Phone \\
\hline 24 & Professor & University of Guelph & $1-5-2017$ & Face to face \\
\hline 25 & Member & $\begin{array}{l}\text { Ontario Greenbelt Council, } \\
\text { Advisory Panel for the } \\
\text { Coordinated Land-Use } \\
\text { Planning Review }\end{array}$ & $16-10-2017$ & Face to face \\
\hline 26 & $\begin{array}{l}\text { Former Staff } \\
\text { Member }\end{array}$ & $\begin{array}{l}\text { Friends of the Greenbelt } \\
\text { Foundation }\end{array}$ & 10-10-2017 & Face to face \\
\hline 27 & $\begin{array}{l}\text { Former } \\
\text { Director }\end{array}$ & $\begin{array}{l}\text { GGH Region Environmental } \\
\text { Organization }\end{array}$ & $13-10-2017$ & Face to face \\
\hline 28 & $\begin{array}{l}\text { Senior Staff } \\
\text { Member }\end{array}$ & $\begin{array}{l}\text { GGH Region Home } \\
\text { Builders' Association }\end{array}$ & 13-10-2017 & Face to face \\
\hline 29 & $\begin{array}{l}\text { Two Senior } \\
\text { Planners }\end{array}$ & $\begin{array}{l}\text { Ontario Ministry of } \\
\text { Municipal Affairs and } \\
\text { Housing }\end{array}$ & $16-10-2017$ & Face to face \\
\hline 30 & Professor & Ryerson University & $16-10-2017$ & Face to face \\
\hline 31 & $\begin{array}{l}\text { Program } \\
\text { Manager }\end{array}$ & $\begin{array}{l}\text { GGH Region } \\
\text { Environmental Organization }\end{array}$ & $17-10-2017$ & Face to face \\
\hline
\end{tabular}




\begin{tabular}{|c|c|c|c|c|}
\hline $\begin{array}{l}\text { Interview } \\
\text { No. }\end{array}$ & Position Title & Organization & Date & $\begin{array}{l}\text { Type of } \\
\text { Interview }\end{array}$ \\
\hline 32 & $\begin{array}{l}\text { Senior } \\
\text { Planner }\end{array}$ & $\begin{array}{l}\text { Ontario Growth Secretariat, } \\
\text { Ministry of Municipal } \\
\text { Affairs and Housing }\end{array}$ & $22-8-2018$ & $\begin{array}{l}\text { Phone } \\
\text { (Follow up } \\
\text { to interview } \\
\text { \# 29) }\end{array}$ \\
\hline 33 & $\begin{array}{l}\text { Senior Staff } \\
\text { Member }\end{array}$ & $\begin{array}{l}\text { Friends of the Greenbelt } \\
\text { Foundation }\end{array}$ & $28-8-2018$ & Phone \\
\hline 34 & $\begin{array}{l}\text { Senior } \\
\text { Planner }\end{array}$ & $\begin{array}{l}\text { Ontario Ministry of } \\
\text { Municipal Affairs and } \\
\text { Housing }\end{array}$ & $29-8-2018$ & $\begin{array}{l}\text { Phone } \\
\text { (Follow up } \\
\text { to interview } \\
\text { \# 29) }\end{array}$ \\
\hline 35 & $\begin{array}{l}\text { Senior } \\
\text { Planner }\end{array}$ & $\begin{array}{l}\text { Municipal Services } \\
\text { Office, Ontario Ministry of } \\
\text { Municipal Affairs and } \\
\text { Housing }\end{array}$ & $18-9-2018$ & Phone \\
\hline 36 & $\begin{array}{l}\text { Urban } \\
\text { Planning } \\
\text { Consultant }\end{array}$ & & 29-10-2018 & Phone \\
\hline 37 & Planner & $\begin{array}{l}\text { Planning Department, } \\
\text { Town of Caledon }\end{array}$ & $5-11-2018$ & Phone \\
\hline 38 & Professor & York University & $7-11-2018$ & Phone \\
\hline 39 & Professor & Western University & 8-11-2018 & Phone \\
\hline 40 & Director & $\begin{array}{l}\text { Municipal Services Office, } \\
\text { Ontario Ministry of } \\
\text { Municipal Affairs and } \\
\text { Housing }\end{array}$ & $20-12-2018$ & Phone \\
\hline 41 & Associate & $\begin{array}{l}\text { Ontario Growth Secretariat, } \\
\text { Ministry of Municipal } \\
\text { Affairs and Housing }\end{array}$ & 3-11-2018 & Phone \\
\hline 42 & Associate & $\begin{array}{l}\text { Ontario Growth Secretariat, } \\
\text { Ministry of Municipal } \\
\text { Affairs and Housing }\end{array}$ & $28-1-2019$ & $\begin{array}{l}\text { Phone } \\
\text { (Follow up } \\
\text { to interview } \\
\text { \# 41) }\end{array}$ \\
\hline 43 & Consultant & $\begin{array}{l}\text { GGH Region Environmental } \\
\text { Organization }\end{array}$ & $2-4-2019$ & $\begin{array}{l}\text { Phone } \\
\text { (Follow up } \\
\text { to interview } \\
\# 12 \text { ) }\end{array}$ \\
\hline 44 & $\begin{array}{l}\text { Senior Staff } \\
\text { Member }\end{array}$ & $\begin{array}{l}\text { GGH Region Conservation } \\
\text { Authority }\end{array}$ & $4-6-2019$ & Email \\
\hline
\end{tabular}





\section{APPENDIX B:}

\section{LIST OF INTERVIEWS FOR THE FRANKFURT CASE}

\begin{tabular}{|c|c|c|c|c|}
\hline $\begin{array}{l}\text { Interview } \\
\text { No. }\end{array}$ & $\begin{array}{l}\text { Position } \\
\text { Title }\end{array}$ & Organization & Date & $\begin{array}{l}\text { Type of } \\
\text { Interview }\end{array}$ \\
\hline 1 & Researcher & Technische Universität Darmstadt & 25-11-2013 & Face to face \\
\hline 2 & $\begin{array}{l}\text { Two Civil } \\
\text { Servants }\end{array}$ & $\begin{array}{l}\text { GreenBelt Group, } \\
\text { Department of } \\
\text { Environment, } \\
\text { City of Frankfurt am Main }\end{array}$ & 27-11-2013 & Face to face \\
\hline 3 & $\begin{array}{l}\text { Senior Staff } \\
\text { Member }\end{array}$ & $\begin{array}{l}\text { Regionalverband } \\
\text { FrankfurtRheinMain }\end{array}$ & $18-9-2017$ & Face to face \\
\hline 4 & Civil Servant & $\begin{array}{l}\text { Nature Conservation } \\
\text { Authority, City of } \\
\text { Frankfurt am Main }\end{array}$ & $18-9-2017$ & Face to face \\
\hline 5 & $\begin{array}{l}\text { Two Staff } \\
\text { Members }\end{array}$ & $\begin{array}{l}\text { Regionalpark Ballungsraum } \\
\text { RheinMain GmbH }\end{array}$ & $19-9-2017$ & Face to face \\
\hline 6 & Chair & $\begin{array}{l}\text { Environmental Organization, } \\
\text { Frankfurt am Main }\end{array}$ & $19-9-2017$ & Face to face \\
\hline 7 & Researcher & Technische Universität Darmstadt & 21-9-2017 & $\begin{array}{l}\text { Face to face } \\
\text { (Follow up to } \\
\text { interview \# 1) }\end{array}$ \\
\hline 8 & $\begin{array}{l}\text { Professor } \\
\text { and } \\
\text { Director }\end{array}$ & $\begin{array}{l}\text { Technische Universität } \\
\text { Darmstadt, Hessian District } \\
\text { Council }\end{array}$ & 22-9-2017 & Face to face \\
\hline 9 & Civil servant & $\begin{array}{l}\text { GreenBelt Group, } \\
\text { Department of } \\
\text { Environment, City of Frankfurt } \\
\text { am Main }\end{array}$ & $22-9-2017$ & $\begin{array}{l}\text { Face to face } \\
\text { (Follow up to } \\
\text { interview \# 2) }\end{array}$ \\
\hline 10 & $\begin{array}{l}\text { Former } \\
\text { Senior Staff } \\
\text { Member }\end{array}$ & $\begin{array}{l}\text { Nature Conservation } \\
\text { Authority, City of Frankfurt am } \\
\text { Main }\end{array}$ & 24-11-2017 & Face to face \\
\hline 11 & $\begin{array}{l}\text { Former Staff } \\
\text { Member }\end{array}$ & $\begin{array}{l}\text { GreenBelt Group, } \\
\text { Department of Environment, } \\
\text { City of Frankfurt am Main and } \\
\text { Regionalpark } \\
\text { Ballungsraum RheinMain GmbH }\end{array}$ & 21-11-2017 & Phone \\
\hline
\end{tabular}




\begin{tabular}{|c|c|c|c|c|}
\hline $\begin{array}{l}\text { Interview } \\
\text { No. }\end{array}$ & $\begin{array}{l}\text { Position } \\
\text { Title }\end{array}$ & Organization & Date & $\begin{array}{l}\text { Type of } \\
\text { Interview }\end{array}$ \\
\hline 12 & Member & $\begin{array}{l}\text { Nature Conservation and } \\
\text { Ornithology Organization, } \\
\text { Frankfurt am Main district }\end{array}$ & 24-11-2017 & Face to face \\
\hline 13 & Member & $\begin{array}{l}\text { "Die Linke" Political Party, City of } \\
\text { Frankfurt am Main }\end{array}$ & 27-11-2017 & Face to face \\
\hline 14 & Architect & & 29-11-2017 & Face to face \\
\hline 15 & Planner & $\begin{array}{l}\text { Urban Development, City of } \\
\text { Frankfurt am Main }\end{array}$ & 30-11-2017 & Face to face \\
\hline 16 & $\begin{array}{l}\text { Staff } \\
\text { Member }\end{array}$ & $\begin{array}{l}\text { IHK Frankfurt am Main (Chamber } \\
\text { of Commerce and Industry) }\end{array}$ & 30-11-2017 & Face to face \\
\hline 17 & Chair & $\begin{array}{l}\text { Nature Conservation } \\
\text { Organization, Frankfurt am Main } \\
\text { district }\end{array}$ & 30-11-2017 & Face to face \\
\hline 18 & Planner & $\begin{array}{l}\text { Urban Development, City of } \\
\text { Wiesbaden }\end{array}$ & $1-12-2017$ & Face to face \\
\hline 19 & Civil Servant & $\begin{array}{l}\text { GreenBelt Group, } \\
\text { Environmental Protection, } \\
\text { Department of Environment, City } \\
\text { of Frankfurt am Main }\end{array}$ & 4-12-2017 & Face to face \\
\hline 20 & Planner & $\begin{array}{l}\text { Urban Development } \\
\text { Division, City of Oberursel } \\
\text { (Taunus) }\end{array}$ & 4-12-2017 & Face to face \\
\hline 21 & Planner & $\begin{array}{l}\text { Urban Planning, Town of Bad } \\
\text { Homburg }\end{array}$ & 5-12-2017 & Face to face \\
\hline 22 & $\begin{array}{l}\text { Director and } \\
\text { Professor } \\
\text { Emeritus }\end{array}$ & $\begin{array}{l}\text { Frankfurt GreenBelt } \\
\text { Project Office (1990-1991), } \\
\text { Frankfurt GreenBelt GmbH } \\
\text { (1992-1996) }\end{array}$ & $6-12-2017$ & Face to face \\
\hline 23 & Planner & $\begin{array}{l}\text { Town Planning Department, } \\
\text { Town of Rodgau }\end{array}$ & $6-12-2017$ & Face to face \\
\hline 24 & $\begin{array}{l}\text { Architect } \\
\text { and } \\
\text { Author }\end{array}$ & & 7-12-2017 & Face to face \\
\hline
\end{tabular}




\begin{tabular}{|c|c|c|c|c|}
\hline $\begin{array}{l}\text { Interview } \\
\text { No. }\end{array}$ & $\begin{array}{l}\text { Position } \\
\text { Title }\end{array}$ & Organization & Date & $\begin{array}{l}\text { Type of } \\
\text { Interview }\end{array}$ \\
\hline 25 & $\begin{array}{l}\text { Consultant } \\
\text { and } \\
\text { Political } \\
\text { Candidate }\end{array}$ & $\begin{array}{l}\text { Former Member of } \\
\text { Frankfurt City Parliament and } \\
\text { Member of } \\
\text { Regierungspräsidium } \\
\text { Darmstadt }\end{array}$ & $7-12-2017$ & Face to face \\
\hline 26 & Civil Servant & $\begin{array}{l}\text { Environment and Nature } \\
\text { Conservation Department, } \\
\text { City of Rüsselsheim }\end{array}$ & $19-12-2017$ & Email \\
\hline 27 & Civil Servant & $\begin{array}{l}\text { GreenBelt Group, } \\
\text { Environmental Agency, } \\
\text { City of Frankfurt am Main }\end{array}$ & $14-3-2018$ & $\begin{array}{l}\text { Phone } \\
\text { (Follow up to } \\
\text { interview \#2) }\end{array}$ \\
\hline 28 & Researcher & Technische Universität Darmstadt & $9-3-2018$ & $\begin{array}{l}\text { Phone } \\
\text { (Follow up to } \\
\text { interview \# 1) }\end{array}$ \\
\hline 29 & $\begin{array}{l}\text { Senior Staff } \\
\text { Member }\end{array}$ & $\begin{array}{l}\text { Regionalverband } \\
\text { FrankfurtRheinMain }\end{array}$ & $27-3-2018$ & $\begin{array}{l}\text { Phone } \\
\text { (Follow up to } \\
\text { interview \# 3) }\end{array}$ \\
\hline 30 & $\begin{array}{l}\text { Former Staff } \\
\text { Member }\end{array}$ & $\begin{array}{l}\text { Regionalpark Ballungsraum } \\
\text { RheinMain GmbH }\end{array}$ & $14-5-2018$ & Face to face \\
\hline 31 & Researcher & Technische Universität Darmstadt & $15-5-2018$ & $\begin{array}{l}\text { Face to face } \\
\text { (Follow up to } \\
\text { interview \# 1) }\end{array}$ \\
\hline 32 & Civil servant & $\begin{array}{l}\text { Regional Settlement and } \\
\text { Spatial Planning } \\
\text { Department, } \\
\text { Regierungspräsidium } \\
\text { Darmstadt }\end{array}$ & $15-5-2018$ & Face to face \\
\hline 33 & $\begin{array}{l}\text { Senior } \\
\text { Official }\end{array}$ & $\begin{array}{l}\text { Hessian Ministry for } \\
\text { Environment, Climate } \\
\text { Protection, Agriculture, and } \\
\text { Consumer Protection, } \\
\text { Wiesbaden }\end{array}$ & $16-5-2018$ & Face to face \\
\hline 34 & $\begin{array}{l}\text { Two Civil } \\
\text { Servants }\end{array}$ & $\begin{array}{l}\text { GreenBelt Group, } \\
\text { Department of Environment, City } \\
\text { of Frankfurt am Main }\end{array}$ & $17-5-2018$ & Face to face \\
\hline 35 & $\begin{array}{l}\text { Senior Staff } \\
\text { Member }\end{array}$ & $\begin{array}{l}\text { Regionalpark Ballungsraum } \\
\text { RheinMain } \mathrm{GmbH}\end{array}$ & $18-5-2018$ & Face to face \\
\hline
\end{tabular}




\begin{tabular}{|c|c|c|c|c|}
\hline $\begin{array}{l}\text { Interview } \\
\text { No. }\end{array}$ & $\begin{array}{l}\text { Position } \\
\text { Title }\end{array}$ & Organization & Date & $\begin{array}{l}\text { Type of } \\
\text { Interview }\end{array}$ \\
\hline 36 & Councilor & City of Frankfurt am Main & $24-5-2018$ & Phone \\
\hline 37 & Politician & $\begin{array}{l}\text { Formerly with the } \\
\text { Environment Department, City } \\
\text { of Frankfurt am Main, Greenbelt } \\
\text { Project Office (1990-1991) }\end{array}$ & $18-6-2018$ & Phone \\
\hline 38 & Researcher & Technische Universität Darmstadt & 21-8-2018 & $\begin{array}{l}\text { Phone } \\
\text { (Follow up to } \\
\text { interview \#1) }\end{array}$ \\
\hline 39 & $\begin{array}{l}\text { Senior Staff } \\
\text { Member }\end{array}$ & $\begin{array}{l}\text { Regionalpark Ballungsraum } \\
\text { RheinMain GmbH }\end{array}$ & $23-8-2018$ & $\begin{array}{l}\text { Phone } \\
\text { (Follow up } \\
\text { to interview } \\
\text { \# 35) }\end{array}$ \\
\hline 40 & Researcher & Technische Universität Darmstadt & 18-7-2019 & $\begin{array}{l}\text { Phone } \\
\text { (Follow up to } \\
\text { interview \# 1) }\end{array}$ \\
\hline
\end{tabular}




\section{SUMMARY}

The origins of greenbelt planning lie in late $19^{\text {th }}$ and early $20^{\text {th }}$ century initiatives to protect greenspaces surrounding cities in the UK and continental Europe. After 1945, the greenbelt concept spread to North America, Australia, and China. In my research, I show that a new generation of greenbelts has developed since the 1990s. These recent greenbelts have multi-functional policy objectives and are often incorporated into comprehensive regional planning frameworks designed to manage urban regions more effectively. However, these integrated policy goals now require involving a wider range of stakeholders in greenbelt management, including farmers, developers, activists, and municipalities.

Acting at arm's length from governments, the private sector, civil society groups and special purpose agencies have also been delegated more responsibility for greenbelt policy implementation, which creates new opportunities and challenges to effectively governing these greenspaces. In addition, regional greenbelts are now embedded within complex and spatially fragmented urban regions that are shaped by regionalised divisions of labour and service industries, commuter flows and suburban growth patterns. This research seeks to examine how these processes have shaped regional greenbelt governance, and questions whether new-generation greenbelt policies can achieve their ambitious objectives. Despite the increasing institutional complexity of these regional greenbelts, the regional governance of these greenspaces is rarely discussed within academic debates.

This research uses three theoretical perspectives to examine greenbelt governance: urban political ecology, regional governance, and an institutional approach to regional governance. First, I use an urban political ecology (UPE) lens to understand what greenbelts are and how they are produced and reproduced. Through a UPE approach, greenbelts can be viewed as hybrid spaces created by social, ecological, and economic processes that together produce these natural environments. A UPE perspective also allows for an analysis of the stakeholders that benefit or are disadvantaged by greenbelt planning, as well as the oftenunjust conditions in the production and renewal of these greenspaces. Second, the regional scale is seen as increasingly important for policy interventions within academic debates, as policymakers need to address problems related to rapid suburbanisation and globalisation, and as regional governance arrangements recently evolved to include more non-state actors in decision-making processes. Third, regional governance is happening within increasing complex institutional arrangements and scholars are questioning the capacity of regional organisations to effectively coordinate policymaking in these fragmented institutional environments. There is long-standing academic debate about which regional institutional form is better, and the capacity of regional governance to effectively address fragmentation across different policy domains, territorial jurisdictions, and policy levels. However, there is 
no consensus in the literature about solutions to regional institutional problems. Finally, the literature also shows that effective regional policy implementation is becoming harder to achieve due to the diversity of stakeholders involved in governance processes, institutional fragmentation, and the growing complexity of public policy issues.

The main aim of this research is to understand how institutional structures shape the coordination of stakeholders involved in governing greenbelts, and how institutional limitations influence policy implementation. I selected two case studies to examine regional greenbelt governance: the Greater Golden Horseshoe (GGH) greenbelt in Ontario, Canada, and the Regionalpark RheinMain in the Frankfurt Rhine-Main region, in Germany. Based on a comparative analysis of these cases, this research also aims to provide recommendations for improving governance of regional greenbelts in the future. The main research question for this dissertation is: How do institutional arrangements shape the governance of regional greenbelts and how could these greenspaces be more effectively governed?

\section{Empirical analysis}

Chapter 2 applies a UPE framework to examine how the territorial boundaries between greenbelts and suburban areas are produced and reproduced through complex socionatural processes, which presents a contrast to the early $20^{\text {th }}$ century conceptions of a clear division between nature and cities. Thus, while greenbelts are designed to create a firm growth barrier, I argue in this chapter that greenbelts can now be viewed as a territorial threshold, forming a more fluid transition zone between the city and the countryside. This chapter explores the changing relationships between nature and the city, and how cities may become more dependent upon a greenbelt's resources in the future due to global environmental change.

Chapter 3 explores the governance challenges involved in implementing GGH greenbelt policy between 2005 and 2010. This chapter discusses the conditions that led to the establishment of the GGH greenbelt, the reactions to the introduction of the Greenbelt Plan by major stakeholder groups, and initial implementation problems. Guided by academic debates on regionalism and rescaling, I argue that the Greenbelt Plan can be viewed as an upscaling of urban-regional regulation in Southern Ontario to a new policy level: the Greater Golden Horseshoe. In addition, the Greenbelt Plan reflects the ambition of a regional sustainability fix, as the provincial government was trying to regulate development pressures and environmental issues at a new regional scale.

Chapter 4 analyses the institutional challenges of upscaling municipal greenbelts to the regional level in the Frankfurt Rhine-Main region. The results show that the effective management of the Regionalpark RheinMain is considerably challenged by the complexity 
of regional institutional arrangements, particularly horizontal, vertical, and territorial coordination problems. The regional greenbelt agency is weakly institutionalised, lacks planning authority, and is situated within a fragmented institutional environment. In addition, given its weak policy protection, Regionalpark implementation can be vulnerable to the region's growth politics. Finally, tensions in the vertical interactions between organisations at different policy levels result in the downscaling of greenbelt planning to municipalities. Accordingly, I argue that the Regionalpark is not appropriately institutionalised to function as a regional greenbelt.

Chapter 5 examines how the GGH region's institutional arrangements have influenced the Greenbelt Plan's implementation from 2003 to 2018. My research reveals that the Greenbelt Plan's vertical institutional design reinforces a hierarchical relationship between the provincial government and municipalities, resulting in coordination challenges at the local scale. In addition, the provincial government failed to fill a long-standing institutional void at the regional level, instead creating several GGH specific policies which produce stakeholder coordination problems. The GGH region's overlapping territories produce unplanned outcomes that affect policy implementation, such as leapfrog development. Finally, my research shows that GGH greenbelt implementation is vulnerable to being undermined by local growth politics and shifting political agendas. Therefore, I conclude that these institutional coordination problems have resulted in inconsistent greenbelt policy implementation, inhibiting these policies from achieving the ambitious changes envisioned by the provincial government.

Based on the discussions in chapters 3, 4 and 5, chapter 6 provides a comparative analysis of how institutional complexities and governance challenges in the GGH and Frankfurt Rhine-Main regions affect regional greenbelt implementation. This chapter also introduces a typology of greenbelts beginning with traditional models from the early $20^{\text {th }}$ century, which were designed to reinforce city-countryside divisions. Modernist greenbelts emerged after the Second World War diverging from their traditional predecessors as cities adapted greenbelt policies to their contexts. By the 1990s, a new generation of greenbelts appeared, often featuring more flexible governance approaches than in the past. Building upon the challenges in vertical, horizontal, and territorial coordination outlined in chapters 4 and 5, this comparative chapter finds that while the GGH greenbelt was more effective in achieving several greenbelt policy goals than the Regionalpark RheinMain, these two cases produced varied outcomes.

\section{Main conclusions and reflections}

My research shows that in both case studies, the challenges in managing the complicated interactions between stakeholders and institutions involved in greenbelt policy implementation creates considerable difficulties. My results demonstrate the significant 
influence that institutions have on greenbelt management, particularly related to vertical, horizontal, and territorial coordination between stakeholders. Vertical coordination in both cases includes top-down and bottom-up approaches that involve power asymmetries between stakeholders at different policy levels, strongly shaping policy implementation. In addition, greenbelt management is influenced by difficulties of horizontal coordination between stakeholders across several policy domains. Regional growth politics can also undermine greenbelt policy implementation. Finally, institutional misfits have caused territorial coordination problems in both cases, which in turn produced unintended policy outcomes. Therefore, one of the main conclusions of my research is that the current institutions supporting new generation greenbelts cannot deliver on their multi-functional policy goals. As a result, I argue that new-generation greenbelts need different institutional designs from what traditional greenbelts had to support their effective governance.

In light of this conclusion, I provide the following seven recommendations for policymakers to improve the governance and planning of regional greenbelts:

- Regional greenbelts require institutional reforms to be more effectively governed, such as reintegrating greenbelt planning from special purpose agencies back into higher government authorities.

- Greenbelt policies need to be supported by additional sectoral policies, such as regional growth plans and nature conservation initiatives, to control urban growth effectively.

- Continuous monitoring of greenbelt policies needs to be institutionalised, and greenbelt policies must be updated regularly to reflect changing regional conditions.

- Civil society groups need to have stronger roles in the design, implementation, and monitoring of greenbelt policies.

- Growth management policies should be coordinated across regions to prevent leapfrog development.

- Developing greenbelts requires long-term perspectives.

- Land market reforms and the introduction of market-based mechanisms are needed to contain low-density development more effectively.

Alongside these policy recommendations, this study provides insights for academic debates related to institutional perspectives on regional governance. Based on three models referring to which institutional arrangement best addresses regional policy issues, my research offers insights for regional greenbelt governance from an institutional perspective. In the Frankfurt case, regional greenbelt implementation reflects the decentralised institutional structures related to new regionalism. In addition, the intense inter-municipal competition within the Frankfurt Rhine-Main region is representative of the public choice 
approach. In contrast, Ontario's top-down government approach to greenbelt planning more closely reflects the metropolitan reform model. In addition, voluntary arrangements that include civil society groups also support GGH greenbelt management, representing a new regionalism approach.

My research thus demonstrates that more senior governmental authorities need to have a strong role in regional greenbelts governance, representing the metropolitan reform model. These higher jurisdiction government authorities have stronger regulatory powers to control regional growth and have authority over the appropriate territorial scale for regional greenbelt implementation. In addition, my research shows that the flexible approaches advocated by new regionalists cannot ensure effective greenbelt implementation alone, as special purpose bodies often have limited authority and institutional capacity. However, the collaborative arrangements associated with new regionalism play a major role in supporting greenbelt implementation, particularly through civil society groups' activities. Finally, my research reveals that as the environmental and societal costs of greenfield development and the benefits of greenbelts and ecosystem services are not internalised in land markets, the market forces and the strong locational competition related to the public choice model negatively impact greenbelt implementation.

Finally, I suggest five areas for future research: (1) the political economies of suburbanisation and their impact on greenbelt management; (2) the economic value of greenbelts; (3) market-based mechanisms to address the economic incentives of decentralised suburban growth; (4) greenbelt planning in countries in the Global South; (5) how institutions supporting greenbelts are created and changed by actors and how that institutional change happens over time. 



\section{SAMENVATTING}

De oorsprong van groengordelplanning ligt in initiatieven die aan het einde van de negentiende en het begin van de twintigste eeuw plaatsvonden om groene ruimten rond steden in het Verenigd Koninkrijk en op het vasteland van Europa te beschermen. Na 1945 verspreidde het concept van de groengordel zich naar Noord-Amerika, Australië en China. In mijn onderzoek laat ik zien dat er sinds de jaren negentig een nieuwe generatie groengordels is ontstaan. Deze recente groengordels dienen multifunctionele beleidsdoelen en maken vaak deel uit van bredere regionale planningskaders die bedoeld zijn om stedelijke regio's beter te beheren. Voor deze geïntegreerde beleidsdoelen is het nu echter noodzakelijk om een breder scala aan belanghebbenden bij het groengordelbeheer te betrekken, zoals boeren, ontwikkelaars, activisten en gemeenten.

De particuliere sector, maatschappelijke groeperingen en gespecialiseerde organisaties, die op enige afstand van overheden opereren, hebben ook meer verantwoordelijkheid gekregen voor de uitvoering van het groengordelbeleid, wat leidt tot nieuwe kansen en uitdagingen voor een effectief beheer van deze groengebieden. Bovendien liggen regionale groengordels nu ingebed in complexe en ruimtelijk gefragmenteerde stedelijke regio's, waarvan het karakter wordt bepaald door de manier waarop de arbeids- en dienstensector, forensenstromen en suburbane groeipatronen per regio zijn verdeeld. In dit onderzoek wordt bestudeerd hoe deze processen richting hebben gegeven aan het regionale groengordelbeleid, en er worden vraagtekens gezet bij de haalbaarheid van de ambitieuze doelstellingen van het beleid voor dit nieuwe soort groengordels. Ondanks de toenemende institutionele complexiteit van deze regionale groengordels komt in wetenschappelijke discussies het regionale bestuur van dergelijke groengebieden zelden aan bod.

In dit onderzoek hanteer ik drie theoretische perspectieven met betrekking tot het bestuur van groengordels: stedelijke politieke ecologie, regionaal bestuur en een institutionele benadering van regionaal bestuur. Ten eerste gebruik ik het perspectief van de stedelijke politieke ecologie (SPE) om te begrijpen wat groengordels zijn en hoe ze worden geproduceerd en gereproduceerd. Wanneer groengordels vanuit SPE-perspectief worden benaderd, kunnen ze worden beschouwd als hybride ruimten, oftewel natuurlijke omgevingen die worden gevormd door een combinatie van sociale, ecologische en economische processen. Vanuit SPE-perspectief kan ook worden geanalyseerd in hoeverre belanghebbenden baat hebben bij of benadeeld worden door groengordelplanning, en welke - vaak onrechtvaardige - condities er bestaan bij het creëren en vernieuwen van deze groengebieden. Ten tweede wordt in wetenschappelijke discussies over beleidsinterventies steeds vaker gekeken naar de regionale schaal. Dit komt doordat beleidsmakers te maken krijgen met problemen van snelle suburbanisatie en globalisering, en door de recente ontwikkeling dat er meer partijen 
van buiten de overheid worden betrokken bij besluitvormingsprocessen in regionaal bestuur. Ten derde vindt regionaal bestuur plaats binnen steeds complexere institutionele context, en wetenschappers vragen zich af of regionale organisaties wel in staat zijn om de beleidsvorming in deze gefragmenteerde institutionele omgevingen effectief te coördineren. Er woedt al geruime tijd een academische discussie over de vraag welke regionale institutionele vorm de beste is, en over het vermogen van regionaal bestuur om de versnippering over verschillende beleidsterreinen, territoriale jurisdicties en beleidsniveaus op een effectieve manier aan te pakken. In de literatuur bestaat echter geen consensus over oplossingen voor regionale institutionele problemen. En ten slotte blijkt uit de literatuur ook dat regionaal beleid steeds moeilijker effectief uit te voeren is, als gevolg van de diversiteit van belanghebbenden die betrokken zijn bij bestuursprocessen, de institutionele versnippering en de toenemende complexiteit van overheidsbeleidskwesties.

Het belangrijkste doel van dit onderzoek is om te begrijpen welke invloed institutionele structuren hebben op de coördinatie van belanghebbenden die betrokken zijn bij het bestuur van groengordels, en hoe institutionele beperkingen de uitvoering van het beleid beïnvloeden. Ik heb twee casestudies geselecteerd om het regionale groengordelbeheer te onderzoeken: de groengordel van de Greater Golden Horseshoe (GGH) in Ontario, Canada, en het Regionalpark RheinMain in het Rijn-Maingebied rond Frankfurt in Duitsland. Op basis van een vergelijkende analyse van deze casussen beoogt dit onderzoek ook aanbevelingen te doen voor het verbeteren van het bestuur van regionale groengordels in de toekomst. De belangrijkste onderzoeksvraag voor dit proefschrift is: Op welke manier geven institutionele regelingen richting aan het bestuur van de regionale groengordels en hoe kunnen deze groengebieden beter worden bestuurd?

\section{Empirische analyse}

In hoofdstuk 2 wordt aan de hand van een SPE-kader onderzocht hoe de territoriale grenzen tussen groengordels en voorsteden (opnieuw) ontstaan in complexe maatschappelijknatuurlijke processen, wat een contrast vormt met de vroegtwintigste-eeuwse opvattingen over een duidelijke scheiding tussen natuur en stad. Hoewel groengordels dus bedoeld zijn als stevige barrière voor groei, stel ik in dit hoofdstuk dat ze tegenwoordig meer als territoriale drempels kunnen worden beschouwd, die een vloeiendere overgangszone tussen stad en platteland vormen. In dit hoofdstuk onderzoek ik de veranderende relaties tussen natuur en stad, en de mogelijkheid dat steden in de toekomst als gevolg van de wereldwijde klimaatverandering afhankelijker worden van de hulpbronnen van een groengordel.

In hoofdstuk 3 wordt gekeken wat tussen 2005 en 2010 de bestuurlijke uitdagingen waren bij de uitvoering van het beleid met betrekking tot de GGH-groengordel. Ik bespreek de omstandigheden die hebben geleid tot de totstandkoming van de GGH-groengordel, de 
reacties van de belangrijkste groepen belanghebbenden op de invoering van het Greenbelt Plan en de aanvankelijke problemen bij de uitvoering. Aan de hand van wetenschappelijke discussies over regionalisme en schaalverandering stel ik dat het Greenbelt Plan kan worden gezien als een opschaling van de stedelijk-regionale regelgeving in het zuiden van Ontario naar het nieuwe beleidsniveau van de Greater Golden Horseshoe. Daarnaast weerspiegelt het Greenbelt Plan de ambitie om tot een regionale duurzaamheidsoplossing te komen, omdat de provinciale overheid probeerde de ontwikkelingsdruk en milieukwesties op een nieuwe regionale schaal te reguleren.

Hoofdstuk 4 bevat een analyse van de institutionele uitdagingen bij het opschalen van de gemeentelijke groengordels naar regionaal niveau in het Rijn-Maingebied. Uit de resultaten blijkt dat effectief beheer van het Regionalpark RheinMain aanzienlijk bemoeilijkt wordt door de complexiteit van regionale institutionele regelingen, met name door horizontale, verticale en territoriale coördinatieproblemen. De regionale groengordelorganisatie is zwak verankerd in instituties, heeft onvoldoende autoriteit op het gebied van planning, en bevindt zich binnen een gefragmenteerde institutionele omgeving. Uitvoering van het Regionalpark-beleid wordt slechts zwak bewaakt, en wordt daarom bedreigd door het groeibeleid van de regio. Verder leiden spanningen in de verticale interacties tussen organisaties op verschillende beleidsniveaus ertoe dat groengordelplanning weer op gemeenteniveau gaat plaatsvinden. Ik stel dan ook dat het Regionalpark onvoldoende geïnstitutionaliseerd is om als een regionale groengordel te functioneren.

In hoofdstuk 5 wordt onderzocht hoe tussen 2003 en 2018 de institutionele regelingen van de GGH-regio van invloed zijn geweest op de uitvoering van het Greenbelt Plan. Uit mijn onderzoek blijkt dat het verticale institutionele ontwerp van het Greenbelt Plan een hiërarchische relatie tussen de provinciale overheid en de gemeenten versterkt, wat resulteert in coördinatieproblemen op lokale schaal. Bovendien heeft de provinciale overheid, in plaats van de reeds lang bestaande institutionele leemte op regionaal niveau op te vullen, diverse GGH-specifieke beleidsmaatregelen opgesteld, die leiden tot problemen met de coördinatie tussen de belanghebbenden. De overlap tussen de gebieden van de GGH-regio leidt tot onvoorziene resultaten die van invloed zijn op de uitvoering van het beleid, zoals ontwikkeling aan de buitenrand van de groengordel (leapfrog development). Verder toont mijn onderzoek aan dat de uitvoering van de GGHgroengordel kwetsbaar is voor ondermijning door lokaal groeibeleid en verschuivende politieke agenda's. Daarom concludeer ik dat deze institutionele coördinatieproblemen hebben geleid tot een inconsistente uitvoering van het groengordelbeleid, wat een belemmering betekent voor het realiseren van de ambitieuze veranderingen die de provinciale overheid voor ogen heeft. 
Op basis van hoofdstukken 3, 4 en 5 wordt in hoofdstuk 6 een vergelijkende analyse gegeven van de invloed van institutionele complexiteit en bestuurlijke uitdagingen op de regionale uitvoering van groengordelbeleid in de GGH en het Rijn-Maingebied. In dit hoofdstuk introduceer ik ook een typologie van groengordels, die begint met traditionele modellen uit het begin van de twintigste eeuw, die waren ontworpen om de scheiding tussen stad en platteland te versterken. Na de Tweede Wereldoorlog ontstonden er modernistische groengordels die afweken van hun traditionele voorgangers doordat steden hun groengordelbeleid aanpasten aan hun eigen context. In de jaren negentig kwam er een nieuwe generatie groengordels, vaak met een flexibelere bestuurlijke aanpak dan in het verleden. In dit vergelijkende hoofdstuk wordt, voortbouwend op de in de hoofdstukken 4 en 5 geschetste uitdagingen op het gebied van verticale, horizontale en territoriale coördinatie, geconstateerd dat er in beide bestudeerde casussen wisselende resultaten waren, maar dat de GGH-groengordel meer succes heeft gehad dan het Regionalpark RheinMain bij het behalen van verschillende groengordelbeleidsdoelen.

\section{Belangrijkste conclusies en overwegingen}

Mijn onderzoek toont aan dat er in beide casestudies aanzienlijke problemen waren bij het managen van de gecompliceerde interacties tussen belanghebbenden en instellingen die betrokken zijn bij de uitvoering van het groengordelbeleid. De resultaten tonen aan dat instellingen een grote invloed hebben op het groengordelbeheer, met name met betrekking tot de verticale, horizontale en territoriale coördinatie tussen de belanghebbenden. De verticale coördinatie betreft in beide onderzochte casussen top-down- en bottomupbenaderingen die asymmetrische machtsverhoudingen tussen belanghebbenden op verschillende beleidsniveaus met zich meebrengen, en die de uitvoering van het beleid in sterke mate bepalen. Bovendien hebben de moeilijkheden bij de horizontale coördinatie tussen de belanghebbenden in verschillende beleidsdomeinen invloed op het groengordelbeheer. Ook regionale groeipolitiek kan de uitvoering van groengordelbeleid ondermijnen. Ten slotte hebben institutionele mismatches in beide gevallen territoriale coördinatieproblemen veroorzaakt, die op hun beurt hebben geleid tot onbedoelde beleidsresultaten. Eén van de belangrijkste conclusies van mijn onderzoek is dan ook dat de huidige instellingen die groengordels van de nieuwe generatie ondersteunen, hun multifunctionele beleidsdoelstellingen niet kunnen waarmaken. Daarom stel ik dat deze nieuwe groengordels alleen effectief kunnen worden bestuurd als ze een andere institutionele opzet krijgen dan de traditionele groengordels.

In het licht van deze conclusie doe ik de volgende zeven aanbevelingen aan beleidsmakers om het bestuur en de planning van regionale groengordels te verbeteren: 
- Om effectiever te worden bestuurd moeten regionale groengordels institutioneel worden hervormd, bijvoorbeeld door groengordelplanning weg te halen bij gespecialiseerde organisaties en weer onder te brengen bij hogere overheidsinstanties.

- Om de stedelijke groei effectief te beheersen moet groengordelbeleid worden ondersteund door aanvullend sectoraal beleid, zoals regionale groeiplannen en natuurbeschermingsinitiatieven.

- Voortdurende monitoring van groengordelbeleid moet worden geïnstitutionaliseerd, en groengordelbeleid moet regelmatig worden aangepast aan de veranderende regionale omstandigheden.

- Maatschappelijke organisaties moeten een grotere rol krijgen bij het ontwerp, de uitvoering en de monitoring van het groengordelbeleid.

- Beleid voor groeibeheer moet regio-overstijgend worden gecoördineerd om leapfrog development te voorkomen.

- Voor de ontwikkeling van groengordels is een langetermijnperspectief noodzakelijk.

- Om kleinschalige ontwikkeling beter in de hand te houden zijn hervormingen van de grondmarkt en de invoering van marktconforme mechanismen nodig.

Naast deze beleidsaanbevelingen bevat dit onderzoek inzichten voor wetenschappelijke discussie met betrekking tot institutionele perspectieven op regionaal bestuur. Op basis van drie modellen die de vraag behandelen welke institutionele regeling het meest geschikt is voor de aanpak van regionale beleidskwesties, biedt mijn onderzoek inzichten voor regionaal groengordelbestuur vanuit institutioneel perspectief. In het geval van Frankfurt weerspiegelt de regionale uitvoering van het groengordelbeleid de gedecentraliseerde institutionele structuren die gerelateerd zijn aan het model van het new regionalism. Daarnaast is de intensieve intergemeentelijke concurrentie binnen het Rijn-Maingebied representatief voor het model van de public choice approach. In Ontario daarentegen weerspiegelt de top-downbenadering van de groengordelplanning vanuit de overheid meer het metropolitan reform-model. Daarnaast wordt het beheer van de GGH-groengordel ondersteund door vrijwillige regelingen waar ook maatschappelijke groeperingen bij betrokken worden, hetgeen neerkomt op een 'nieuw-regionalistische' aanpak.

Mijn onderzoek toont dus aan dat de hogere overheden een sterke rol moeten spelen in regionaal groengordelbeleid, op basis van het metropolitan reform-model. Deze hogere overheden hebben sterkere regelgevende bevoegdheden om regionale groei te controleren en hebben ook zeggenschap over wat de meest geschikte territoriale schaal is voor de regionale uitvoering van groengordelbeleid. Daarnaast blijkt uit mijn onderzoek dat de flexibele aanpak die door de 'nieuwe regionalisten' wordt bepleit, niet voldoende is voor een effectieve uitvoering van groengordelbeleid, omdat gespecialiseerde organisaties vaak beperkt zijn in hun bevoegdheden en institutionele capaciteit. De 
samenwerkingsverbanden die bij new regionalism horen, spelen echter wel een belangrijke rol bij de ondersteuning van de uitvoering van groengordelbeleid, met name via de activiteiten van maatschappelijke groeperingen. En als laatste blijkt uit mijn onderzoek dat, aangezien de milieu- en maatschappelijke kosten van de ontwikkeling van groene zones en de voordelen van groengordels en ecosysteemdiensten niet in grondprijzen verwerkt zijn, de marktkrachten en de sterke locatieconcurrentie in verband met het public choice-model een negatief effect hebben op de uitvoering van groengordelbeleid.

Tot slot doe ik een voorstel voor vijf richtingen voor toekomstig onderzoek: (1) de politieke economieën van suburbanisatie en de gevolgen daarvan voor het beheer van de groengordel; (2) de economische waarde van groengordels; (3) marktmechanismen voor economische prikkels bij gedecentraliseerde groei van voorsteden; (4) groengordelplanning in landen in het mondiale Zuiden; (5) hoe instellingen die groengordels ondersteunen door actoren worden gecreëerd en veranderd, en hoe die institutionele verandering zich in de loop van de tijd afspeelt. 


\section{CURRICULUM VITAE}

Sara Macdonald was born in 1981 in Toronto, Canada. Her main research interests have developed throughout more than 15 years of academic and professional work, and include greenbelts, urban and regional planning, regional governance, and suburbanisation. She completed her Bachelor's and Master's degrees in Environmental Studies at York University in Toronto, Canada. From 2006 to 2017, Sara was the Coordinator of the City Institute at York University (CITY), which is a university-based research centre that focuses on critical urban research. For seven of those years (2010-2017), she was also the Project Coordinator of a major collaborative research initiative entitled "Global Suburbanisms: Governance, Land, and Infrastructure in the $21^{\text {st }}$ century", which studied established and emerging forms of suburbanisation throughout the world. In 2017, Sara joined the Department of Human Geography and Spatial Planning at Utrecht University as a PhD candidate. Her PhD research was part of the Global Suburbanisms project and during her studies, she was a visiting scholar at Technische Universität Darmstadt in Darmstadt, Germany. 




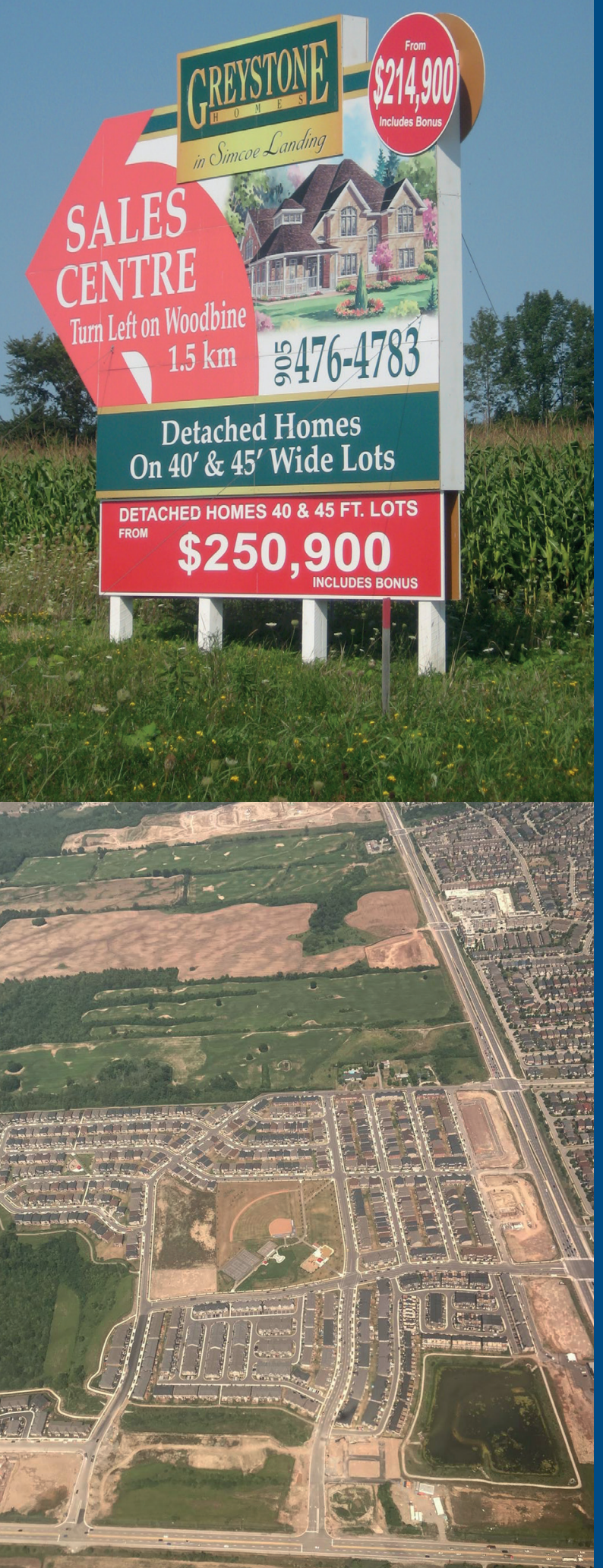

In the last 30 years, a new generation of greenbelts has emerged in planning practice. These recent greenbelts have multifunctional policy goals and are often part of comprehensive regional land-use planning frameworks designed to manage regional growth more effectively. However, these regional greenbelts are increasingly under threat from suburban low-density development and the expansion of infrastructure networks, and their governance is embedded in complex institutional arrangements. These evolving circumstances create considerable challenges for policymakers seeking solutions to effectively govern these regional greenbelts. This study explores how institutional arrangements shape the governance of regional greenbelts in the Greater Golden Horseshoe region of Southern Ontario, Canada, and in the Frankfurt Rhine-Main region, Germany, as well as how these greenspaces could be more effectively managed in the future. The study shows that addressing the complex interactions between institutions and stakeholders involved in greenbelt management creates significant difficulties in coordinating policy implementation across different policy levels, policy fields and jurisdictions. Thus, this study reveals that the current institutional arrangements supporting new generation greenbelts cannot fully deliver on their ambitious policy objectives. To overcome these problems and to effectively manage these greenspaces, this study points to institutional design reforms needed for a new generation of greenbelts. 